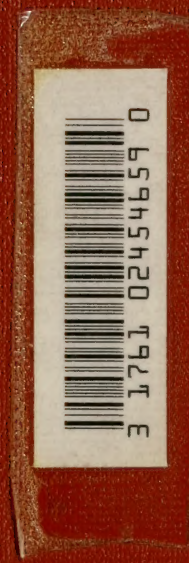


Digitized by the Internet Archive in 2007 with funding from Microsoft Corporation 


BULletin No. 7.

U. S. DEPARTMENT OF AGRICULTURE. DIVISION OF AGROSTOLOGY.

[Grass and Forage Plant Investigations.]

\title{
AMERICAN GRASSES.
}

\author{
(IILUSTRATED.)
}

BY

F- IAMSON-SCRIBNFR, AGRostologist.

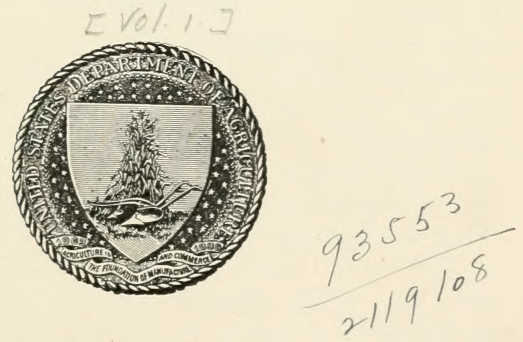

WASHINGTON :

GOVERNMENT PRINTING OFFICE.

1897. 


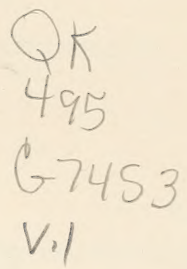




\section{LETTER OF SUBMITTAL}

\section{U. S. Department of Agriculture, \\ Division of Agrostology, Washington, D. C., January 22, $189 \%$.}

SiR: I submit herewith a number of illustrations of native and introduced grasses, with brief descriptions and notes upon the distribution of each, based upon the collections of the Department, and recommend their publication as Bulletin No. 7 of this Division. These illustrations were primarily designed toillustratea Handbook of North American Grasses, in which all the North American species are to be figured, but as it will be some time before the remaining figures can be engraved, it has been suggested that three hundred of those now completed be published, in order to render them imme. diately useful and available to others. If the present form of publication had been orginally contemplated, a different selection of figures would doubtless have been made. This is of small importance, however, as it is hoped to publish illustrations of all the species in the near future, and it is for this reason that references to the detail drawings are omitted. Notes upon the uses and value of the species of economic interest were published in Bulletin No. 3 of this Division, "Useful and Ornamental Grasses." 
The drawings are all from carefully selected specimens, the habit sketches being made by Mr. A. H. Baldwin. The enlarged details were drawn by myself, with the exception of a few which were made by Miss M. D. Baker. The engraving is the work of Mr. L. S. Williams and Mr. George P. Bartle. The work has all been done in the office of the Division, with the exception of that performed by Mr. Bartle.

Respectfully,

F. LAMSON-SCRIBNER,

Hon. Chas. W. Dabney, Jr., Agrostologist. Assistant Secretary of Agriculture. 


\section{INTRODUCTION.}

In order to make the present publication more useful to students of grasses, the order Graminex and the several tribes into which the order has been divided by our best authorities are here briefly characterized. Under the tribes the genera which are native or have been introduced are enumerated, and those having species figured in this bulletin are marked with an asterisk (*).

\section{GRAMINERーGRASSES.}

Characters of the order.-Fibrous-rooted, annual or perennial, . herbaceous (rarely woody) plants, with usually hollow, cylindrical (rarely flattened) and jointed stems (culms) whose internodes for more or less of their length are enveloped by the sheath-like basal portion of the two-ranked and usually linear, parallel-veined leaves; flowers without any distinet perianth, hermaphrodite or rarely unisexual, solitary or several together, in spikelets, which are arranged in panicles, racemes, or spikes, and which consist of a shortened axis (the rachilla) and two or more chaff-like, distichous imbricated bracts (glumes), of which the first two, rarely one or none or more than two, are empty (empty glumes); in the axil of each of the succeeding bracts (excepting sometimes the uppermost) is borne a flower (hence these are named flowering glumes). Opposed to each flowering glume, with its back turned toward the rachilla, is (usually) a two-nerved, two-keeled bract or prophyllum (the palea), which frequently envelops the flower by its infolded edges. At the base of the flower, between it and its glume, are usually two very small hyaline seales (lodicules); 
rarely there is a third lodicule between the flower and the palea; stameus, usually three (rarely two or one, or more than three) with very slender filaments and two-celled, usually versatile anthers; pistil with a one-celled, one-ovuled ovary, and one to three, usually two, styles with variously branched, most frequently plumose, stigmas; embryo small, lying at the front and base of the seed, covered only by the thin pericarp; fruit a caryopsis, rich in albumen. (In Sporobolus and Eleusine the thin periearp is free from the seed.)

Number of species.-There are about thirty-five hundred known species of grasses, varying in size from the mosslike Coleanthus of the North to the tree-like bamboos of the Tropies, which tower to the height of $30 \mathrm{~m}$. or more; and ranging in distribution from Kerguelen Land on the South to the extreme limit of vegetation beyond the Arctic Circle. There is no order of plants more widely distributed, or existing under a greater diversity of soil and climate, and no other order presents such a vast number of individual plants or is so important and directly useful to man.

\section{SERIES A.-PANICACEA.}

Spikelets one-rarely two-flowered; when two-flowered the second or terminal one is perfect, the first or lower one being either staminate or neuter; rachilla articulated below the empty glumes, the spikelets falling from the pedicels entire, either singly, in groups, or together with the joints of an articulate rachis. The first six tribes belong to this series.

Tribe I.-Maydea.

Spikelets unisexual, the staminate forming a part of the inflorescence with the pistillate, or each in a separate inflorescence on the same plant; flowering glumes hyaline or much less firm in texture than the outer ones; axis of the female spikelets usually artieulated. 
This is a small tribe, numbering only sixteen species classed in seven genera. They are nearly all natives of the Tropies, chietly in the Old World. Indian corn, or maize, is our best known example of the Maydea.

Enchlona Schrad.

Zea Linn.

Tripsacum Linn.*

Trub II.-Andropogonea.

Spikelets in spike-like racenes, two at each joint of the articulite rachis, one sissile and hermaphodite, one perlicellate, the latter hermaphrodite, staminate, neuter. or reduced to the pedicel alone; glumes usually four, the first and second emptr. larger and much firmer in texture than the others, the third usually empty, with a staminate flower in its axil, very rarely awned, the fourth or flowering glume hyaline, usually awned, awn usually twisterl or genieulate.

This tribe contains about four hundred species divided among twenty-nine genera. of which the genus Andropogon, with one hundred and ninety speries, is by far the largest and probably the most important. Sugar cane belongs to this tribe in the genus succhrrum. Our best known representatives of the Andropogoneir are the common broom serlge, Andropogon virginicus, and the big blue stem, Andropogon prorincialis. In the same genus are now elassed our species of sorghum. The members of the tribe are distributed throughout the tropical and warmer regions of both hemispheres.

Imperata Cyr. *

Miseanthus Anderss.

Saccharum Limn.

Erianthus Michx.

Manisuris Liun. *

(Rottboellia Lim. f.)
Hackelochloa kiuntze. *

(Manisuris Sw. not Liun.)

Traehypogon Nees.

Ėlionurus HBK.

Andropogon Lim. 


\section{Tribe III.-Zoysiee.}

Spikelets solitary or in groups of two to eight, each group falling as a whole from the continuous rachis, usually one-flowererl, hermaphrodite, or staminate and hermaphrodite in the same group; tlowering glume less firm in texture than the awned or awnless onter ones, which are herbaceous, chartaceous, or coriaceons; the first glume is usually larger than the second.

A small tribe, numbering about twenty-five species which represent nearly half that number of genera. Fifteen species are natives of the tropical and warmer temperate regious of America. Black grama, or Galleta, as the Mexicans name it, species of Hilaria, are our best-known representatives of the tribe.

Hilaria Kunth.* Agopogon HBK.
Nazia Adans. (Tragus Hall).

Zoysia Willd.

\section{TRIBE IV.-Tristeginea.}

Spikelets all hermaphrodite, in panicles; empty glumes three, or the third with a staminate flower in its axil, herbaceons or chartaceous; Howering glumes nembranaceous, awned or awnless; rachilla articulated helow the empty glumes.

A small tribe of only seven genera and thirty-three species, natives chiefly of the tropical regions of the Oli World. Of the few American species none extend so far north as the United States.

\section{Tribe V.-Panicer.}

Spikelets hermaphrodite, terete or llattened on the back; glumes three or four (rarely ouly two); when four there is oceasionally a staminate Hower or a palea in the axil of the third; the uppermost or flowering glume of the hermaphrodite flower is always firmer in texture than the onter glumes, of which the first is usually smaller than the others; axis of the inflorescence not articulated, the rathilla being artienlated below the empty glumes, the sprikelets falling oft' singly from their perlicels. 
This is one of the largest tribes in the order Gramineit. It contains twenty-two genera with over six hundred and thirty species. Punicum, the principal genus, is the largest among grasses, numbering three hundred species. The Panicere are very widely distributed throughout the tropical and temperate regions of the world. Crab-grass and the millets are among our best known examples of this tribe.

Reimaria Fliigge.

Paspalum Linn.*

Anthrenantia Beauv.

Amphicarpon Raf.

Eriochloa Kunth.*

Panicum Linn.*
Oplismenus Beauv.

Chetochloa Seribn.*

(Setaria Auct.)

Cenchrus Linn.

Pennisetum Pers.*

Stenotaphrum Trin.

TRIBE VI.-Oryzed.

Spikelets usually much compressed laterally; one-flowered, staminate, pistillate, or hermaphrodite; empty glumes two or none, the flower being subtended by the floral glume and palea alone, the latter one-nerved and regarded by some as a second glume; stamens frequentlysix; axis of the inflorescence not articulated.

A small tribe of about forty species divided among sixteen genera, mostly confined to tropical America. One of the best known and most extensively used of the cereals, rice (Oryza sativa), belongs here.

Hydrochloa Beauv.

Pharus Linn.

Luziola Juss. *

Zizaniopsis Doell and Asch.
Zizania Linn.

Oryza Linn.

Homalocenchrus Mieg, *

(Leersia Sw.)

\section{SERIES B.-POACEA.}

Spikelets one- to many-flowered, the imperfect or rulimentary flower, if any, usually uppermost; rachilla 
usually articulated above the empty glumes, so that these remain after the fall of the fruiting glume. ${ }^{1}$ In spikelets with two or more flowers these are separated by a manifest internode of the rachilla, and in such cases the rachilla is usually articulated below each flowering glume.

\section{Trine VII.-Phalaridea.}

Spikelets more or less laterally compressed, one- or rarely threeflowered: glumes five, the first two empty aud below the artienlation of the rachilla, the third and fonrth above the artioulation, usually empty, very unlike the outer ones, rarely subtending staminate flowers, sometimes reluced to mere bristles, the fifth glume with a one-nerved or nerveless palea and a hermaphrodite flower.

A small tribe, eomprising six genera with about sixty species of comparatively little importance. Several of the species, sweet verual grass and vanilla grass, are remarkable for possessing a peculiar fragrance due to their containing coumarin. Canary-grass is one of the best known members of this tribe.

Phalaris Linn.*

Anthoxanthum Linn.*
Savastana Schrank.* (Hierochlö̈ Gmelin).

\section{Tribe VIII.-Agrostidea.}

Spikelets all hermaphrodite, one-flowered with three glumes, the first two empty (very rarely wauting), usually as long as or exceeding the third or floral glume; rachilla sometimes prolonged behind the palea into a naked or plumose bristle. Palea two-nerved (one-nerved in Cimna), nerveless, or (in some Agrostis species) wanting.

${ }^{1}$ Alopecurus, Cinnu, Spartina, and Holeus among our grasses. have the rachilla articulated below the first pair of glumes, and the spikelets fall off entire. 
This is, next to the Festucer, the largest tribe in the order, numbering seven hundred species arranged in forty-six genera. The species are distributed throughont all the temperate and colder regions of the world and many oceur within the Tropies. The genus Agrostis, from which the tribe derives its name and from which comes the word "agrostologist," has about one hundred species, found in all parts of the world, especially in the north temperate zone. Some of our most important meadow grasses-notably Herd's-grass and timothybelong to this tribe.
Aristicla Linn.
Stipa Linn.* ${ }^{*}$
Epicampes Presl.*
Oryzopsis Michx.*
Polypogon Desf:
Milium Linn.
Limuodia L. H. Dewey.*
Muhlenbergia Schreb.*
(Thurberia Benth.)
Brachyelytrum Beauv.*
Aretagrostis Griseb.
Lyeurus Kunth.
Pereilema Presl.
Cinna Linn.
Agrostis Linn.
Gastridium Beanv.
Heleochloa Host.*
Calamagrostis Roth. *
Phleum Linn.
Ammophila Host.*
Alopecurus Linn. *
Calamovilfa Seribn.*
Coleanthus Seidl.
Phippsia R. Br.
Apera Adans.
Lagurus Linn.

Sporobolus R. Br.*

\section{Tribe IX.-Avener.}

Spikelets two- to several-flowered; onter empty glumes usually longer than the first floral glume; one or more of the floral grlumes awnel on the hack or from hetween the teeth of the hific apex: awn usually $t$ wisted or geniculate; the callus, and usually the joints of the rachilla, hairy.

A tribe comprising twenty-three genera and orer three hundred speries widely distributed in the temperate regions of both the Old and the New World. particularly abumdant in South Afica and Australia, a few extending beyond the arctic circle. 
Several of the species are valued as forage plants. Cultivated oats, Avena sativa, is the best-known example of this tribe.

Holeus Linn., in part. * Aira Linn. *

Weingaertneria Bernh.* (Corynephorus Beauv.) Trisetum Pers.* Avena Linn.* Arrheuatherum Beanv.* Deschampsia Beauv.

Danthonia DC.

Tribe X.-Chlorider.

Spikelets one- to several-flowered in one-sided spikes or racemes; these racemes digitate or fasciculate, rarely solitary; flowering glumes usually keeled, entire and unawned, or toothed, and with one or three straight awns.

A small tribe of twenty-seven genera and one hnndred and fifty-five species, characterized chiefly by the inflorescence, which is nearly that of Paspalum. The awns when present are not dorsal nor twisted, as in Agrostidee and Arener. Chiefly uatives of tropical and subtropical countries; a few are widely distributed as weeds throughont the warmer parts of the world. A number are good turf-forming grasses, and are valued for grazing purposes. One of these is the celebrated butfalo-grass of the Western plains, which is remarkable for having the staminate and pistillate spikelets separate and in unlike inflorescences, either upon the same plant (monocious) or upon different plants (dioxcious).

Capriola Arlaus.

(Cynodon Pers.)

Spartima Sehreb.

Campulosus Desv.

(Ctenium Panzer).

Chloris Sw.

'Trichloris Fourn.

Gymnopogon Beauv."
Sehedonnardus Stend.*

Bonteloua Lag. *

Beckmannia Host. *

Eleusine Gaertu. *

Dactyloctenium Willd. *

Lepitochloa Beauv.*

Bulbilis Raf.

(Buchlö̈ Engelu.) 
Tribe XI.-Festucer.

Spikelets two- to many-flowered, usually hermaphrodite, pedier. late in racemes or panicles, the lizter sometimes deuse and spikelike; flowering glumes usually longer than the empty oues, awnless or with one to several straight (rarely bent) awns which are either terminal or borne just below the apex.

This is the largest tribe in the order, numbering seventy-six genera and about seven hundred and twenty-five species. It contains the most important meadow grasses of the temperate regions as well as the more prevalent grasses of the higher mountains within the Tropics. The genus Poa, which includes Kentucky blue-grass, Texas blue-grass, ete., numbers one hundred species, and an equal number of species are included in the genus Eragrostis. The Fescues number eighty species, and the tribe takes its name from this genusFestuca. Orchard grass, Dactylis glomerata, is a wellknown example of this tribe.

Pappophorum Schreb.

Cottea Kunth.

Cathestecum Presl."

Scleropogon Philippi.

Monanthochlö̈ Engelm. *

Munroa Torrey.

Oreuttia Vasey.

Gynerium HBK.

Arundo Linn.

Phragmites 'Trin.*

Blepharidachne Hack.

(Eremochloë S. Wats.)

Triodia R. Br. *

Sieglingia Bernh.

Redifieldia Vasey. *

Dissanthelium Trin.

Molinia Schrank.

Eragrostis Host.*

Eatonia Raf.*

Koeleria Pers.*

Catabrosa Beauv. *
Melica Linn. *

Korycarpus Zea.*

(Diarhena Raf.)

Pleuropogon R. Brown. *

Uniola Linn.

Distichlis Raf.*

Briza Linn. *

Dactylis Linn. *

Cynosurus Linn.

Lamarekia Noench.*

Poa Limn.*

Colpodium 'Trin.

Dupontia R. Br.

Scolochloa Link.

Graphephorum Desv."

Panicularia Fabr.*

(Glyceria R. Br.)

Puccinellia Parl.*

Festuea Linn.*

Bromus Linn. 
TrIBF XII.-Horder.

Spikelets one- to many-1lowered, usually hermaphrulite, sessile along the common rachis, forming a simple or compouml spike; ${ }^{1}$ glumes awned or awnless.

A small tribe of twenty genera and about one hundred and thirty species. It is an important division, however, for it includes rye, barley, and the many varietiesof wheat. English and Italian Rye-grasses (Lolium species) are the chief meallow grasses of the tribe.

Narclus Linn.*

Lolium Linn. *

Lepturus R. Br.

Seribneria Hack.

Agropyron Gaertn.
Secale Linn.

'Triticum Linn.

Hordeum Linn."

Elymus Linn.

Asperella Humb.

Tribe XIII.-Bambusea.

Spikelets two-to many-flowered (rarely only one-flowered) in raremes or panicles; empty glumes at the base of the spikelet two to several; flowering glumes many-nerved, awnless, or very rarely short-awnerl: "ulms woody, at least near the base, and perennial; leaf blade usually with a short petiole articulated with the sheath from which it finally separates.

A comparatively small tribe of twenty-three genera and about one humbed and eighty-five speries. The species are confined chiefly to the region within the Tropics. Many of them are of very great importance to the natives of the comntries where they grow. Mamu. factured articles of bamboo, either of use or for ormament, are now a part of the commerce of the world. The hamboos are remarliable for their woody stems and often arborescent or tree-like habit of growth, some of the

Strietly the spike is simple when the sessilu spikelets are oneflowered, and romponnd when they are more than one-tlowered. 


\section{5}

species attaining the height of 25 to $30 \mathrm{~m}$. In parts of India they form extensive forests. One species in this tribe has leaves 2 to $5 \mathrm{~m}$. long by 10 to $25 \mathrm{~cm}$. wide; another, a Cuban species, has leaves 5 to $8 \mathrm{~cm}$. long and as fine as a horse hair. Fleshy and edible, apple-like fruits are borue by some of the species.

Arundinaria Michx.

F. L.S. 



\section{AMERIC AN GRASEES.}

(ILLUSTRATED.)

BY F. LAMISON-SCRIBNER.

$11162-N 0.7-2$ 


\section{METRIC MEASUREMENTS AND TIEIR ENGLISH EQUIVALENTS.}

The metric system adopted in this Bulletin is now quite generally employed in botanical and other scientific publications. For those unfamiliar with this system the following expression of equivalents may be useful:

1 millimetre $(1 \mathrm{~mm}$.) =one twenty-fifth of an inch-exactly 0.0394 inche.

1 centmetre $(1 \mathrm{~cm})=$. nearly one-half of an inch $; 10 \mathrm{~cm} .=$ ahout 4 inches.

1 décimètre $(1 \mathrm{~lm})=$. about 4 inches, or $3 \mathrm{dm} .=$ one foot.

1 mitre $(1 \mathrm{~m})=$. about 3 feet $3 \frac{\mathrm{g}}{\mathrm{g}}$ inches-exactly 39.37079 inches. 


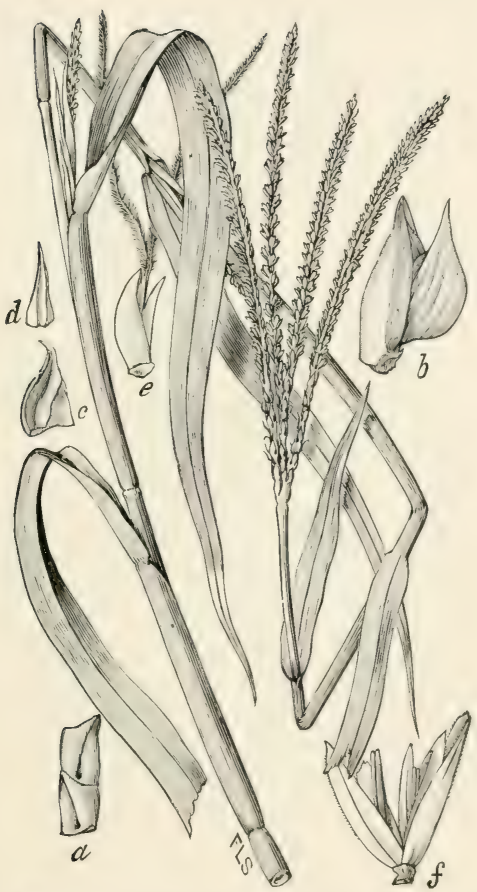

Fig. 1. Tripsacum dactyloides L. Gama-grass.-A stont, coarse, branching perennial ! to $24 \mathrm{dm}$. high, with loug amb rather hroad leaves and a spieate inflorescence, the spikes being 22 to 4 on the main stem and usually solitary on the branches. - Low meadows, moist thickets, ditches, etr.; Rhode Island to Florida, Kansas, and Texas. [Mexico.] April-Oetober. 


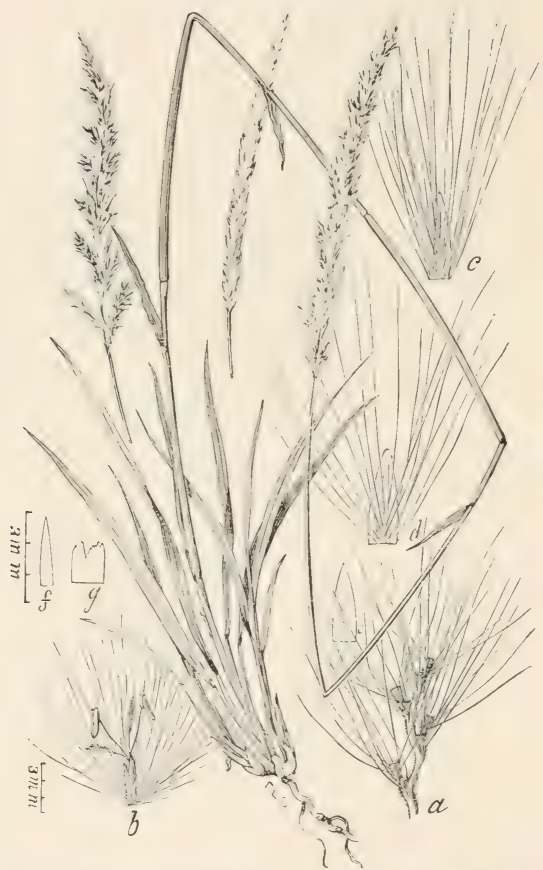

Fig. 2. Imperata hookeri Rupr. (I. Trevifoliu Vasey ; I. cuudulu Scribn, not Trin.); Beal, (irasses N. Am., 2 : 22.-A stout, glabrous perennial 5 to $12 \mathrm{dm}$. high, with strong, creeping rootstocks, tlat leates, and elongated white-hairy, densely flowered panicles. Western Texas, Nevada, New Mexico, Arizona, Nouthern California and southward. 


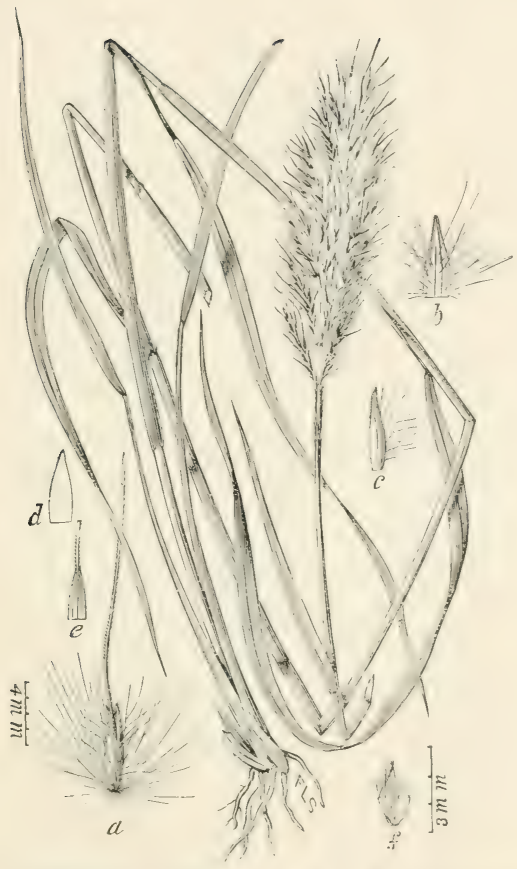

Fiti, 3. Erianthus compactus Nash in Bull. Torr. Jot. ('luh),

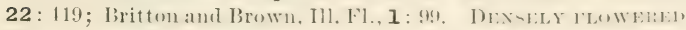

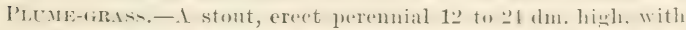
long, narrow leaves and densely Howered. ohlong. lowwnish or red-

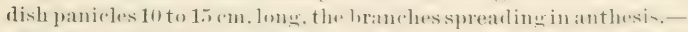
Meadowa and swamps, mostly nar the coust: Now lersey to Virginia ant T'ennessce. August-October. 


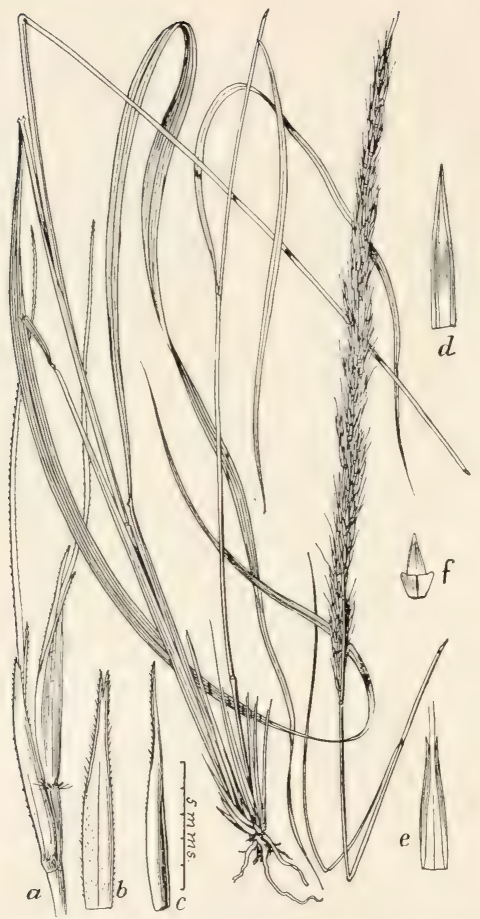

FIG. 4. Erianthus strictus Baldw.; Beal, Grasses X. Am., 2: 29. - A stont, ereet peremial 12 to $21 \mathrm{~cm}$. high, with long, narrow, flat leaves and strict, bearded (with : wns), but not hairy, panicles, 20 to $40 \mathrm{~cm}$. long.-River hottoms, Tennessee and Georgia to Mississippi and Texas. September, Octoler. 


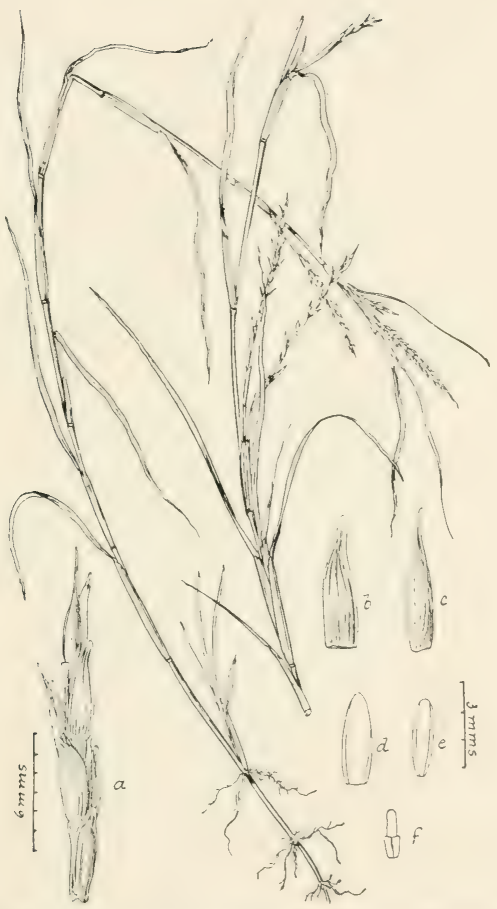

FI(. ). Manisuris compressa (L. f.) Kuntze (liotlbolllia rompressu L.f.; Hemarthrinfusciculata Kunth). MAT-(inssi-A - reeping perennial, with ascending and usually much branched, flattened culms 10 to 14 dm. high, and numerons slender spikes.River banks, sonthwestern Trxas. [Tropical and subtropical regions of both hemispheres.] September. 


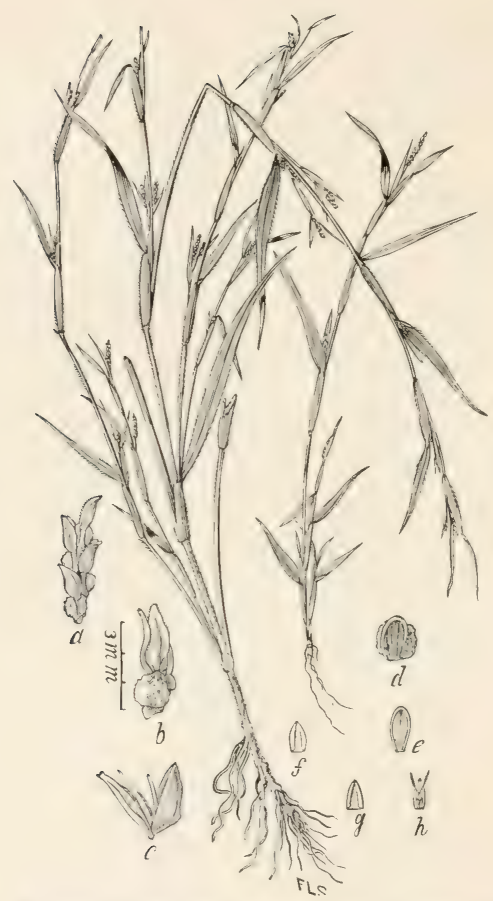

FI(i, 6. Hackelochloa granularis (Sw.) Kuntze (Munisuris grunuluris sw.; Cenchrus granuluris Linu.); Beal, (rrasses X. An., 2: 33. LizARD-TuLl-iriss.-A much-branched, leafy anunal, 3 to $12 \mathrm{dm}$. high, with numerous slender spikes in irregular, leafy panicles. $-\lambda$ weed in all tropical comntries, extending northward into the warmer parts of the fouthern and fouthwestern itates. 


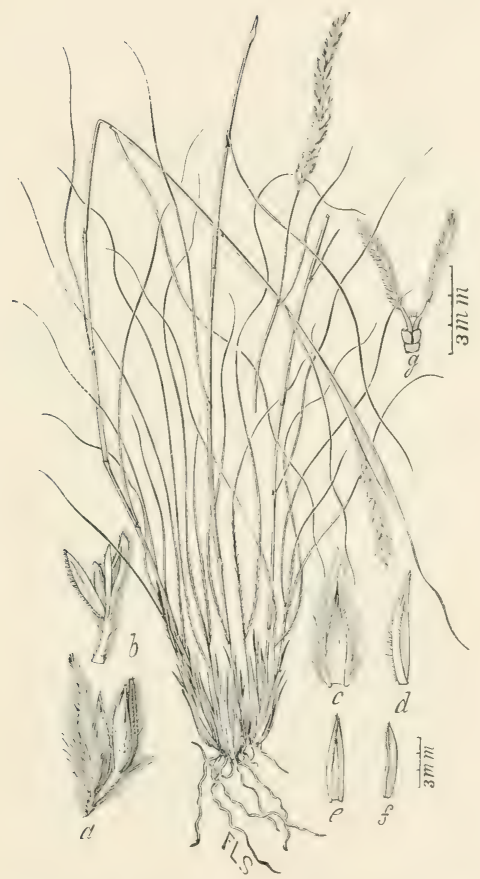

Fic. 7. Elionurus barbiculmis Hack. Beal, (irasses $\mathrm{X}$. Im., 2: 37.-A slemiler, erect perennial 4 to $7 \mathrm{dm}$. high, with very narrow, filiform, hairy leaves and silky-villoms, solitary spiles

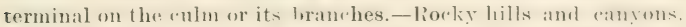
western Texas to Irizona. [Northern Mexieo.] June-september. 


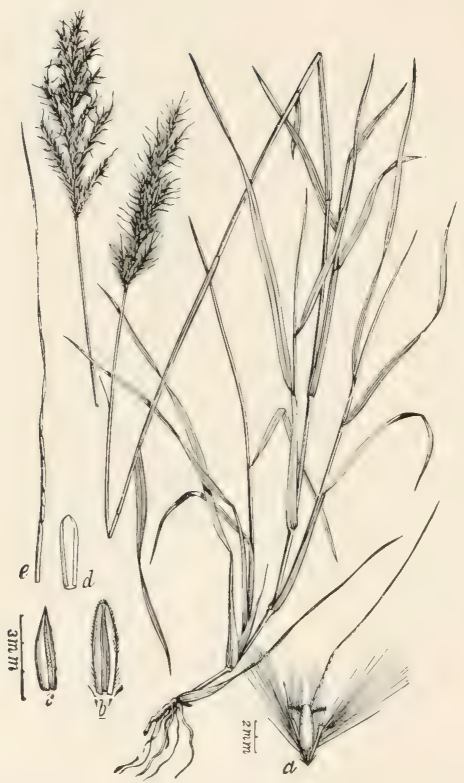

FI(i. 8. Andropogon saccharoides torreyanus (Nteud.) Hack; Britton and Brown, 1: 103 (Andropogon torreyanus Steud.). Torimy's SILver: BEalid-GiAss.- $\Lambda$ variahle native perenuial 3 to 9 dm. high, with rather lonw, usually glancons, flat leaves, and narrow silvery-bearded panicles.-lyry prairies and mesas, Kansas to Texas, New Mexico, and Nevadi. [Mexico.] July-October. 


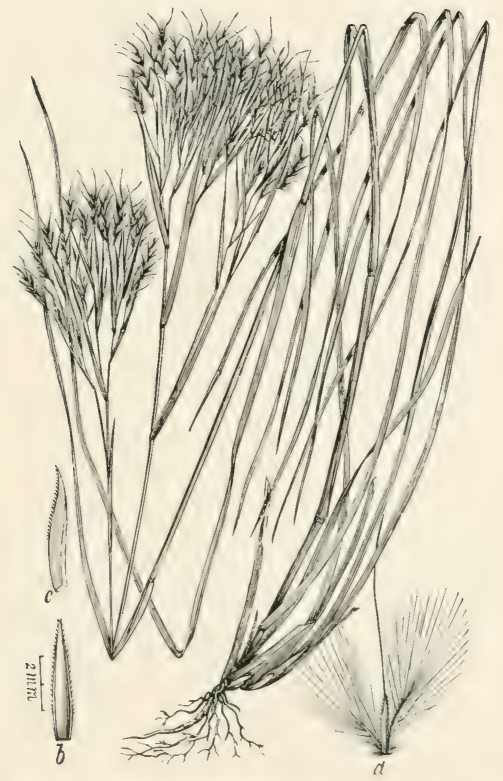

Frti. 9. Andropogon glomeratus (Walt.) B. S. P'. (Andropoyon macrourus Michx.). Brook-(iRAsis.-A stout perennial ti to 12 dm. high, with dense, more or less elongated panicles, the hranches nonally very much crowded.-Low groumls and marshes, southern New York to Florida, sonthern California and Yevada. [Mexieo, Lower California, Cuba, and damaica. september-Jannary. 


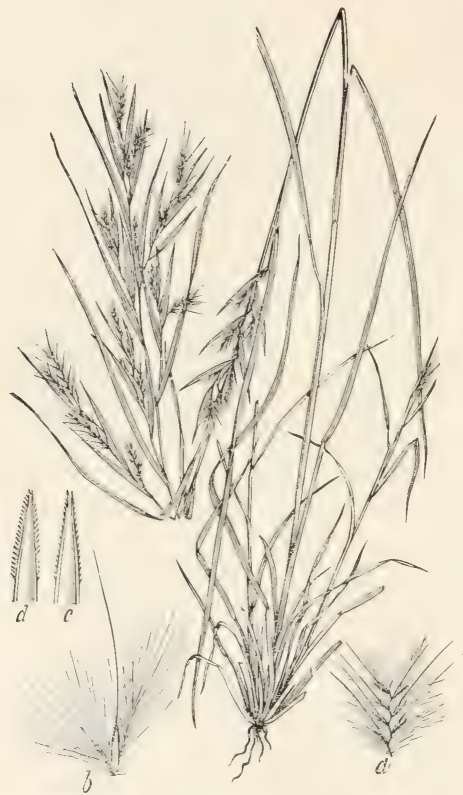

Frti, 10. Andropogon virginicus L. Brom Sente.-A rigidly erent peremnial 6 to 12 dm. high, with the culms flattened near the base, and narrow, clongaterl, and loosely branched panicles of silky-hearded racemes, for the most part partially inclosed within smooth, spathe-like lwacts.-Old tields and horders of mools. usually in try suil. Massachusetts to Florida and Texas. [Cuba.] August-October. 


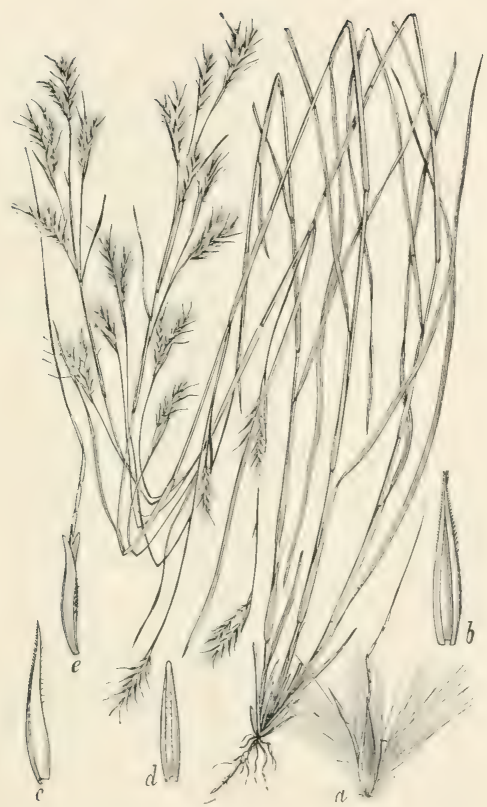

Fir. 11. Andropogon argyraus sehultes. Sirver-likiln or

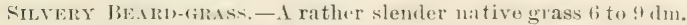
high, with narrow leaves and silky-bearded racemes, which are in pairs, trrminal on the enlm or its branches, - In dry, samely soil in open wools and aloug thicket horders from leelaware to Missouri and sonthward to the Gulf: Angust-October. 


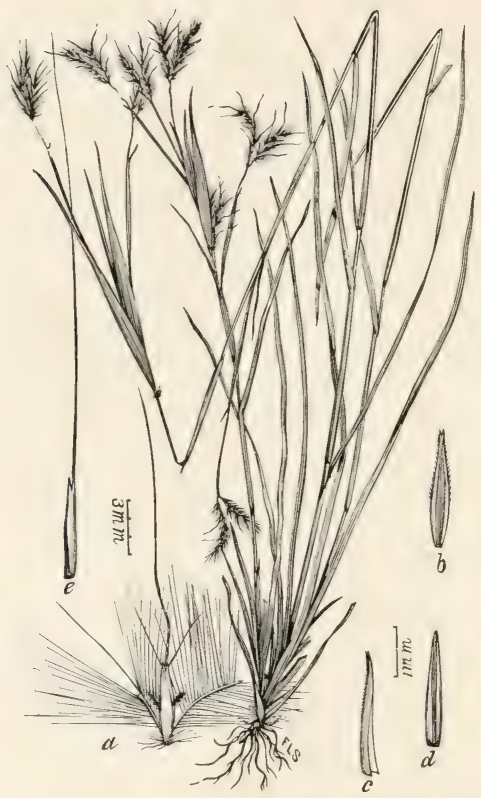

Firi. 12. Andropogon elliottii Chapm. Elliott's Broos SEviE.-A slender, upright perennial 6 to $9 \mathrm{dm}$. high, the plumose racemes in pairs or ternate and subtended by couspicuously inflated upper leaf sheaths.-Dry upland wook or low pine barrens, Delaware and Penusylvania to central Florida and Texas. July-October. 


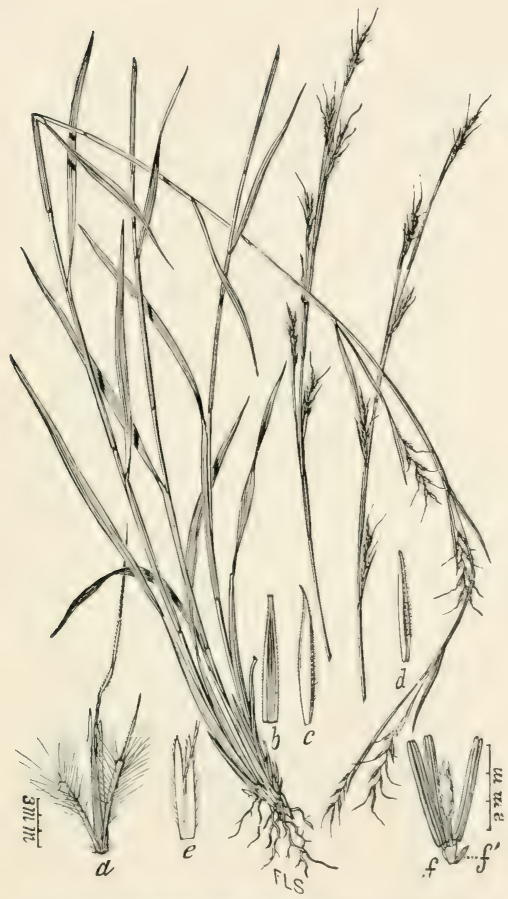

Fig. 13. Andropogon scoparius Michx. Littie Blue-STen.A rather slender perennial 3 to 4 dm. high, the solitary racemes terminating the culms and branches.-Dry fields and borclers of woods, New Brumsick westward to the Saskatehewan, Bonthward to Florida, Toxas, and sonthern California. [Mexico.] JulyOctober. 


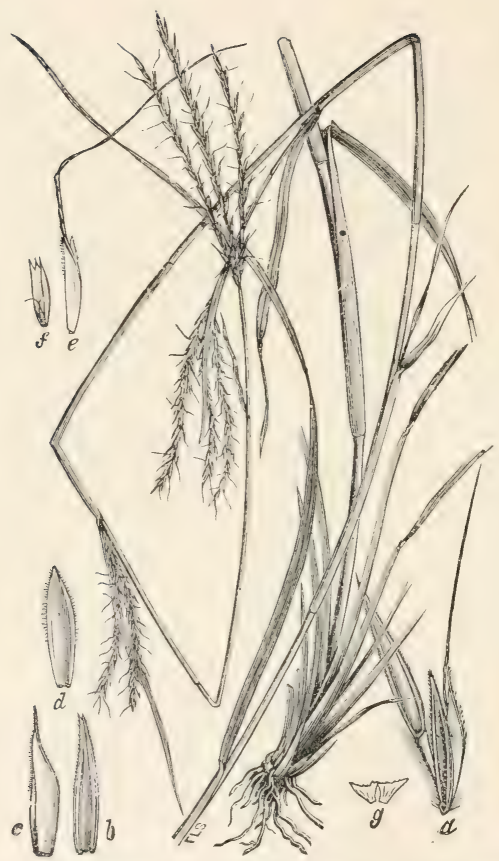

FIG. 14. Andropogon provincialis Lam. (A. furcatus Muhl.) Hit: BLCE-STEx. - A stout perennial 6 to $16 \mathrm{dm}$. high, with long leaves, and rather thirk spikes 3 to $10 \mathrm{~cm}$. long.-From the Rocky Mountains eastward to the Atlantic and southward to the Ginlf of Mexico. Angust-Oetoher. Lspecially abundant and ralued for hay in the prairie regions. 


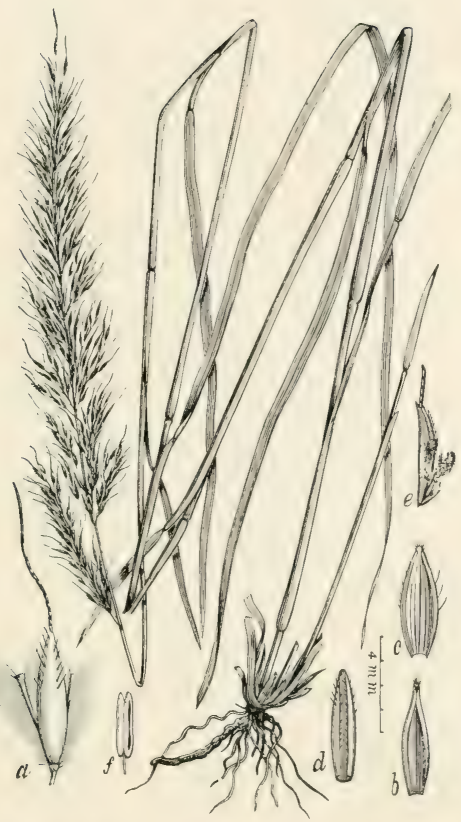

Fis. 15. Andropogon nutans avenaceus (Michx.) Hack. IxDIAN (irass. - A stont perennial 12 to 18 dur. high, with long leaf blates, and long, rather dense, usually somewhat nodding brownish panicles.-1)ry fields, glailes, and horders of woods, Ontario to South Dakota and Manitoba, south to Florida. Texas, amel Arizona. [Mexieo, Central and Sonth America.] July-Uctober. $11162-$ No. $7-3$ 


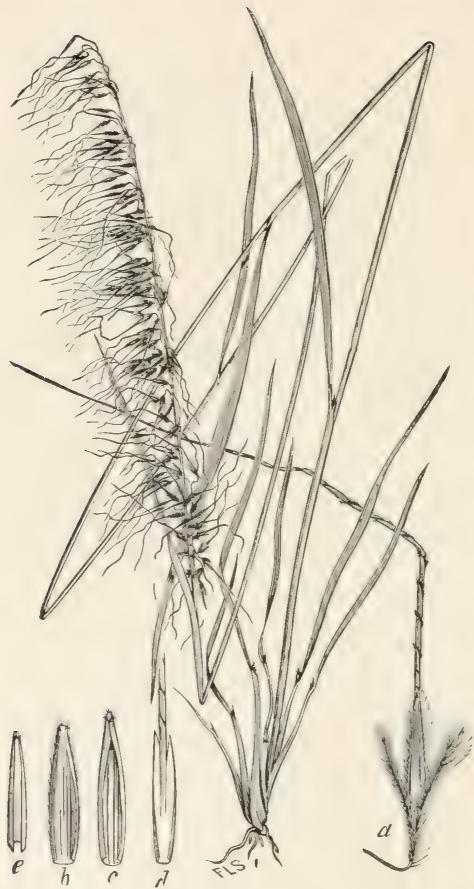

FIG. 16. Andropogon unilateralis Hack.; Beal, Grasses $\mathrm{N}$. Am., 2:60. (.Imdropogon secundus Ell. not Willd.) BaxNer SoRtrucu.-A rather stout perennial, 6 to $12 \mathrm{dm}$. high, withnarrow, one-sided, many-flowered panicles 18 to $25 \mathrm{~cm}$. long. and longawned spikelets,-Low pine lands, South Carolina, Hlorida. JuneOctober. 


\section{5}

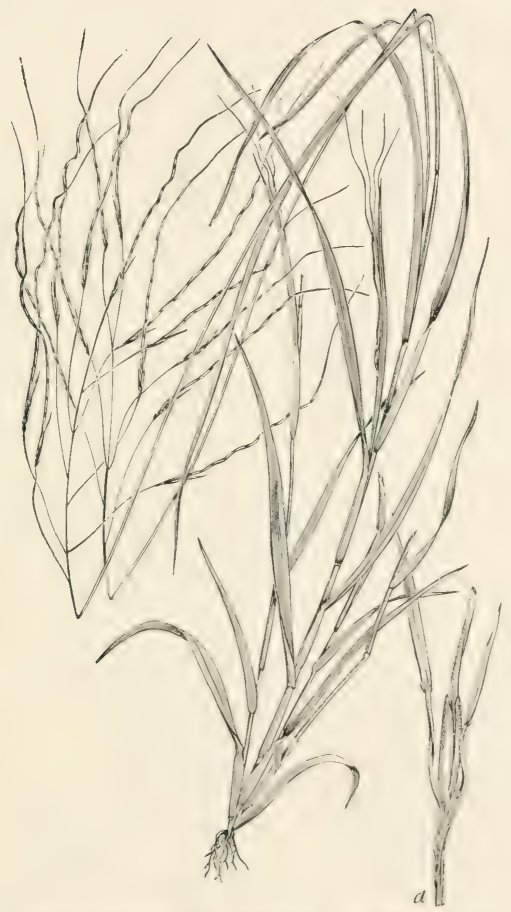

FIf: 17. Andropogon pauciflorus (chapmm.) Hatek, Beal, Grasses N. Am., 2: 61. (Śmghum punciflorum ('halpm.). FEW-

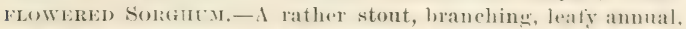
6 to 1: dm. high, with few-1lowerol panicles and long-awned spikelets.-Dry fields, Florila. [Cuba.] Oetober. 


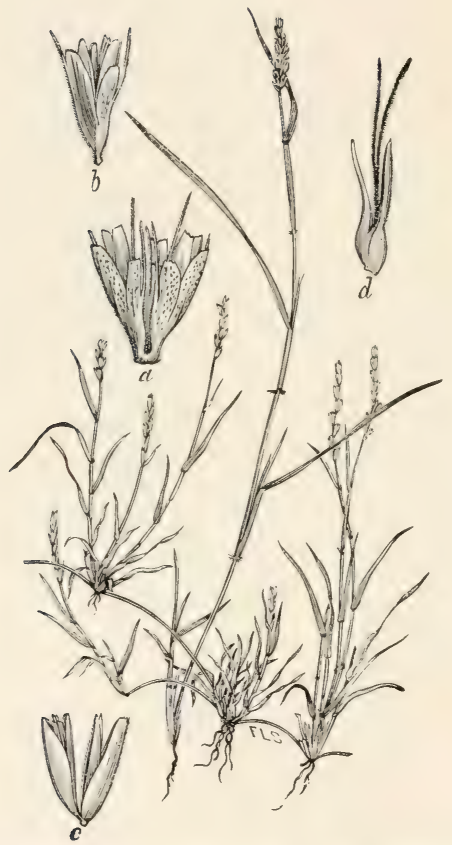

Fic, 18. Hilaria cenchroides HBK.; Beal, Grasses N. Am., 2 : 68. Crefing Mesoute.-A slender, creeping perennial, with upright leafy branches 1 to $3 \mathrm{dm}$. high.-Dry prairies, mesas, and foothills, Texas to Arizona. [Mexico.] April-October, One of the most valuable of the native grasses for grazing. 


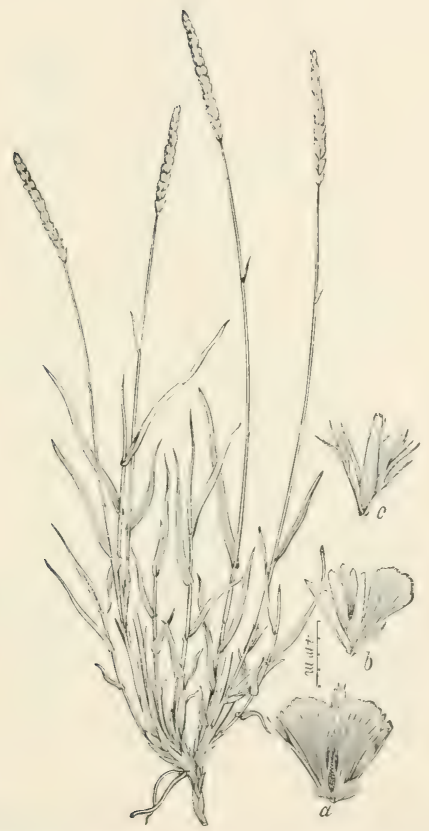

Fif. 19. Hilaria mutica (Burkl.) Benth.: Beal, dirasies N.

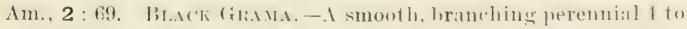
fi dum. high, with densely llowerenl, nsmally straw-colored spilies about $5 \mathrm{~cm}$. long.-Dry mesas, Texas to sonthern California. May-september. Valued for forage, eppecially for orazing. 


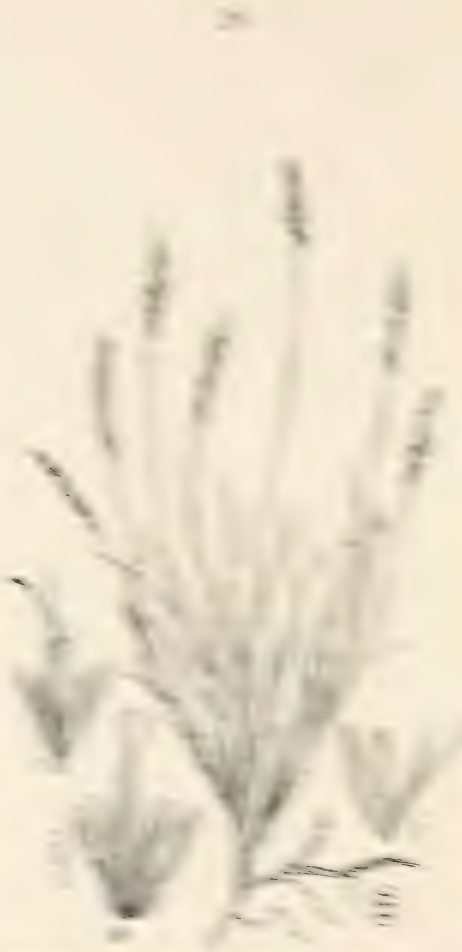

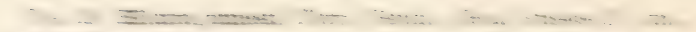

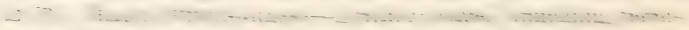

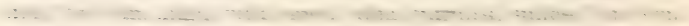

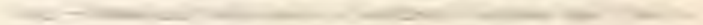

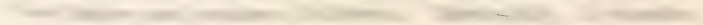
$\sqrt{20}$ 


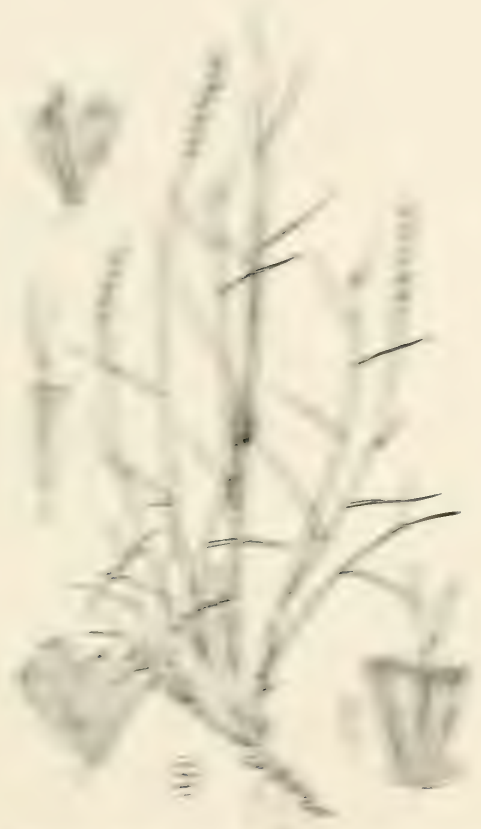

$\equiv \cdots+\cdots+\cdots+\cdots+\cdots$

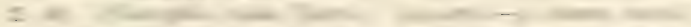
a

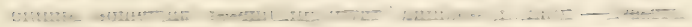

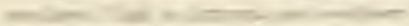

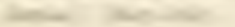




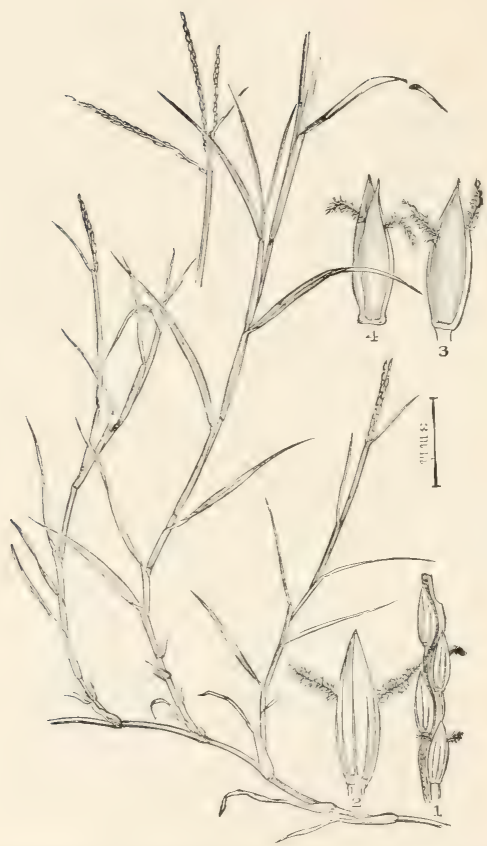

Fut, 22. Reimaria oligostachya 11 mro in Benth. Journ. Linn. Soc.; Beal, Grasses N. Am., 2:80. Creeping Remaria.-Au extensively ereeping perennial, with llat leaves and upright thowering branches 2 to $t$ dul high. hearing two to four spikes $t$ to $\tau$ 'm. long.-I)itches and hrackish river shores, often in water, easteru Florida. [Cuba.] April-September. 


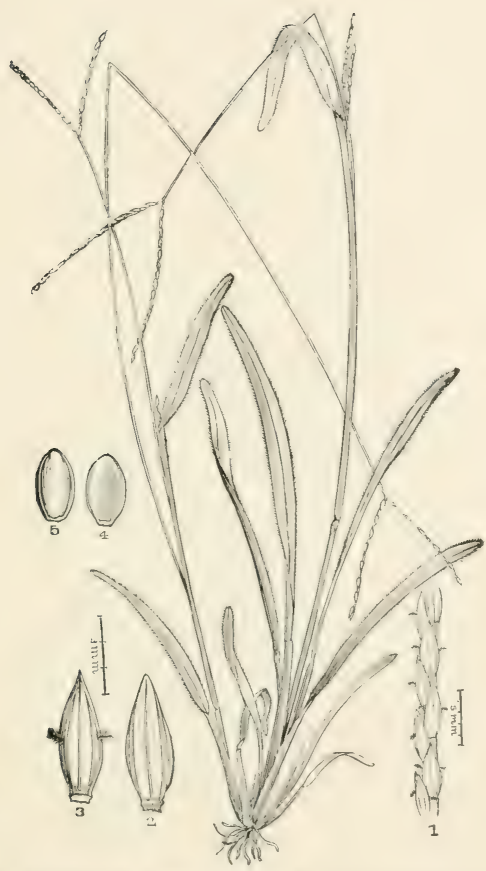

Fri. 23, Paspalum paspaloides (Michx.) Aerihn, I', fllintlii S. Wats.; I'. digitaria P'oir.). Ellotot's PASIALum. A soft perennial grass 5 to $x$, hm. high, geniculate and more or less erepepine at the base, with rather broal, flat leaves and sleneier spikes. which are nsually in pairs.- loorlers of ponds and diteles and in low pine harrens near the coast, Maryland to Texas. Ipril-Angust. 


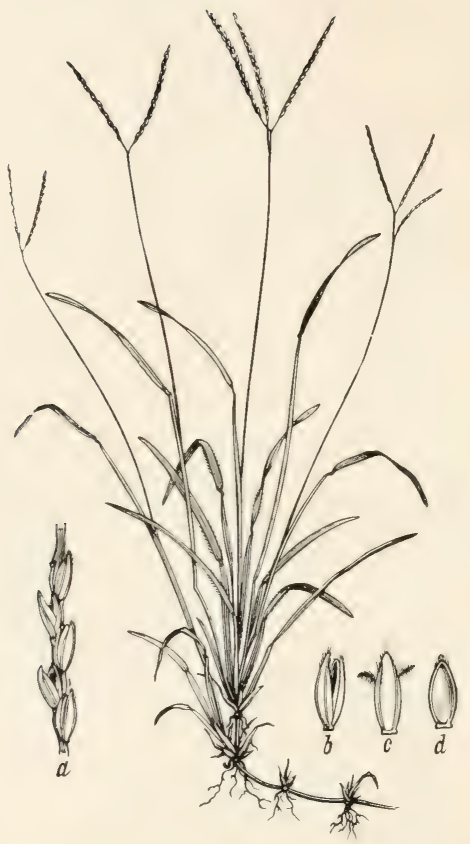

Fri. 24. Paspalum compressum (Sw.) Nees. ( $P$. platycaule Poir. l. Lutisina or ('ARPET-iRAss.-A slender, erect, or more frequently prostrate and extensively reeping perennial, rooting at the nodes aud senting up numerons leafy or flower-bearing branches 1.5 to 6 dm. high, with 2 to 6 subdigitate slemder spikes and small, antish spikelets.-Low ground and moist pastures, abundant near the coast from Virginia to Texas. [Mexico, Central and South America, and West Indies.] April-().tober. A valuablo pasture grass. 


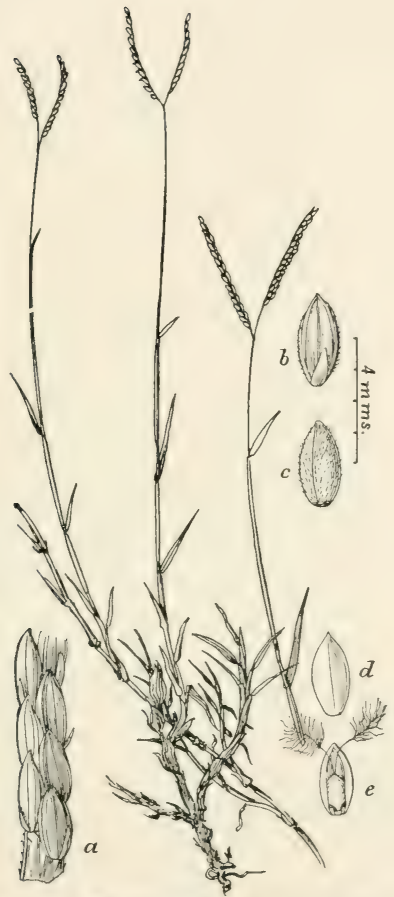

Fic, 25. Paspalum distichum L. Kxot-Gliss.-A low, ereeping, somewhit suceulent perennial, with flat leaves and two spikes at the apex of the upright flower-bearing branches, which are 1 to 3 dim. high. Itabit of growth resemblung Bermudagrass.-Ditehes and muddy or sandy shores, Virginia and Missour to Florida, Texas, and southern Califorma; northward on the Pacific Coast to Oregon. [Widely distributed in tropneal and subtropical regions.] April-Oetober. 


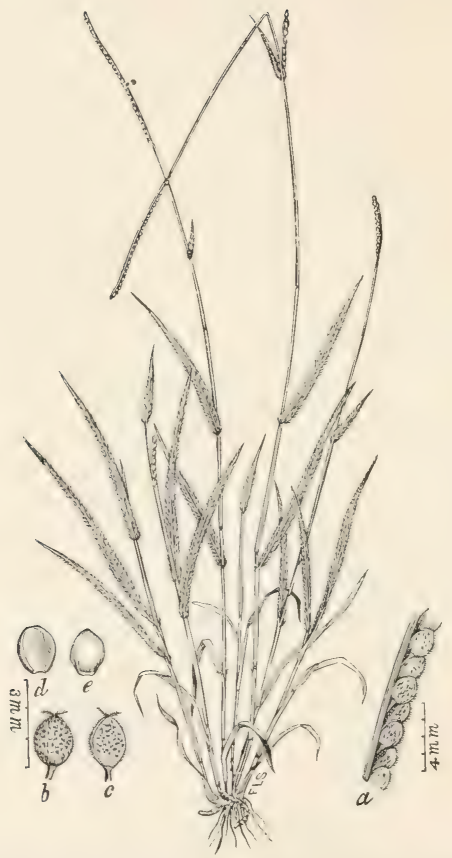

Fig. 26. Paspalum setaceum Mirhx. Stexter PAspalur.$A$ slender, ereet, or ascending native peremial, usually ahout 6 dm. high, with flat, often hairy leaves, and sleuder, small-flowered spukes.-lory, sandy fielels and pine barrens, Massachusetts to rortheastern Vebraska, Texas and Floricla. April-Oetoler. 


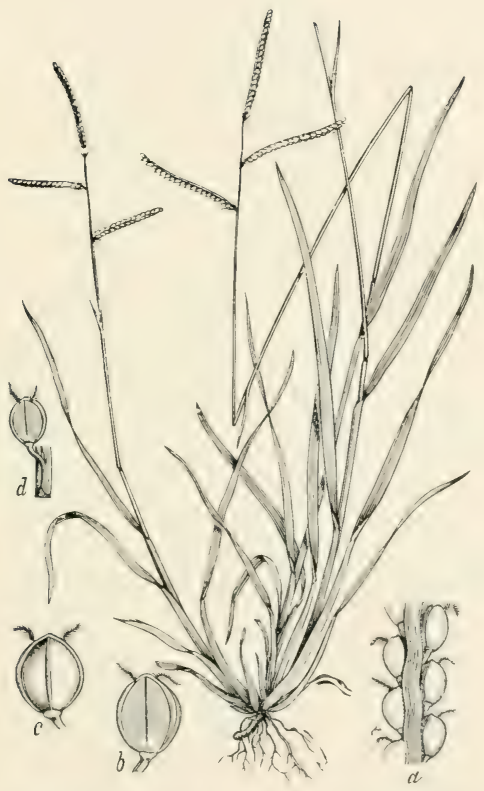

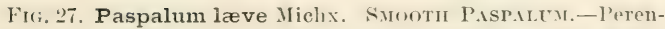
nial, witl ascending culms, often genculate at base, :3 to 9 dm. high, with smooth or pilose leat sheaths and blades, and $: 3$ to 7 spreading spikes to $10 \mathrm{~cm}$. long. Low, of en wet, ground, lihode Island to Florida, eastern Texas and Missonri. June-betoher. 


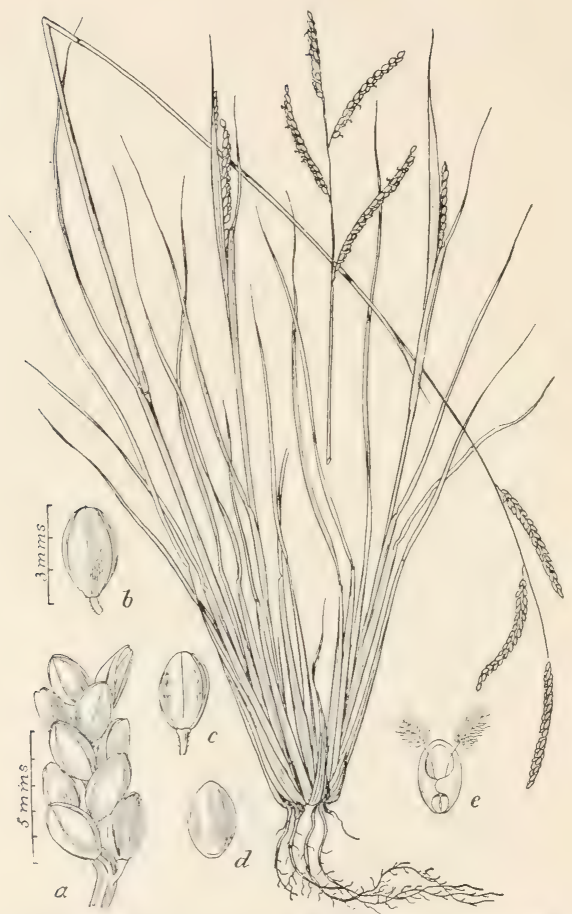

FIf. 28. Paspalum plicatulum Michx.; Beal, frasses $\mathrm{X}$. Am., 2:90. WHINKLE-FoWERED PAsPALA.-An erect or ascending perennial 3 to $6 \mathrm{dm}$. high, with smooth or flat leaves and 5 to 7 rather densely flowered racemes. The second glume is usually plieate or wrinkled.-Dry fields and open pine woods, Georgia and Floricla to Texas. [Mexico, ('entral amd South America, and West Indies.] April-Octoher. 


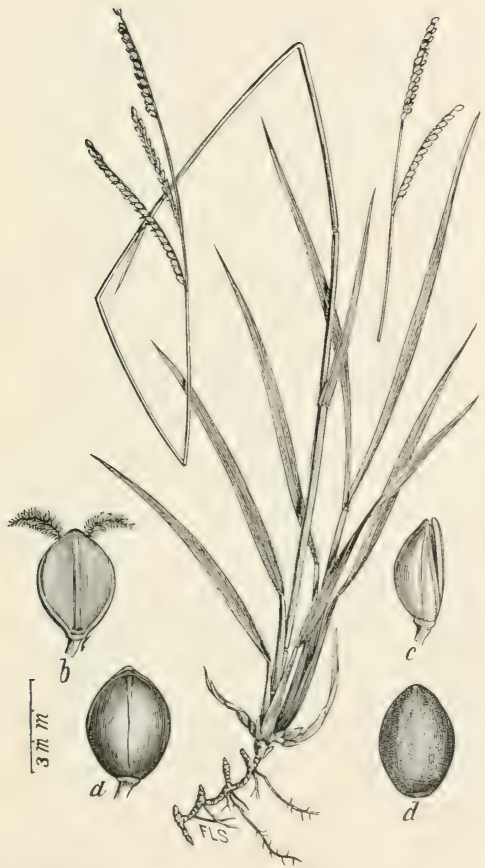

Fit. 2!). Paspalum difforme Ide Conte; Vasey Proc. Acal. Natt. Sci. Phila. 1N8t, 2xi. - I stout perennial, from ereeping rontstorks. Allied to $I$ '. Jloridanmm, hut less robust, with shorter leaves and spikes.-1)ry pine barrensmear the coast. North ('arolina to Floricla and westward to Texas. June-October. 


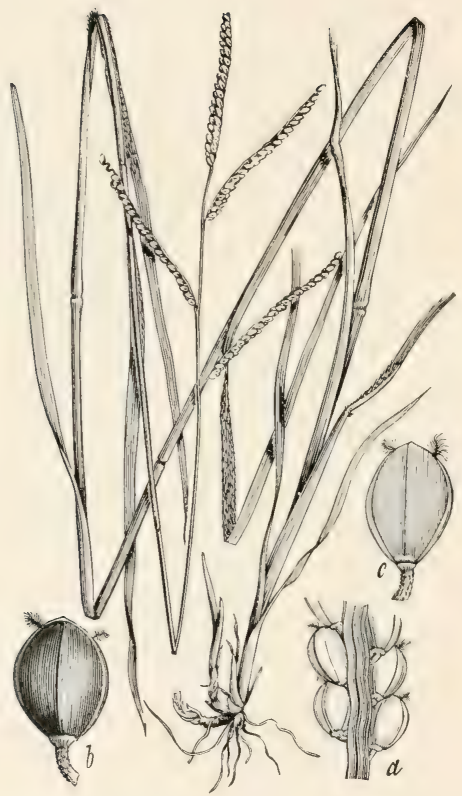

Fig. 30. Paspalum floridanum Michx. Florida Paspalum.A stout, erect grass 9 to $12 \mathrm{dm}$. high, often glancons, with long leaves, smooth or villous sheaths and blates, and large spikelets. Dry or moist low gromnd, lelaware to Florida, Texas, Kentucky, and Indian Territory. June-Oetober. 


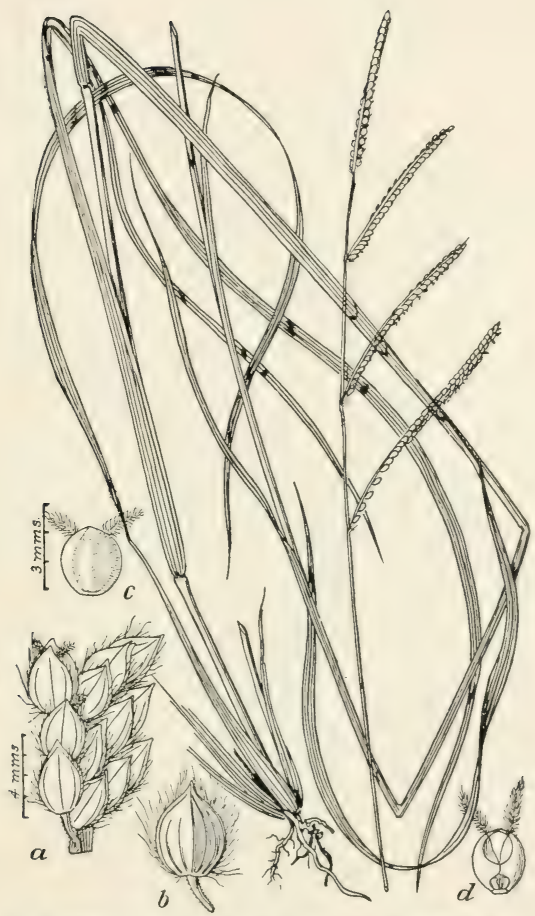

Frr. 31. Paspalum dilatatum Poir. ( $I$ '. matum Nees). L.1rif WATER-Girass. - A somewhat eoarse, leafy perennial, growing in clumpe 6 to 15 din. hiph, bearing 2 to 10 more or less spreading racemes of hairy spilielets. - In meadows, waste gromml, and along ditches, southeastern Virginia to Florida, west to Texas; apparently naturalized. [South America.] July-Octohes. 


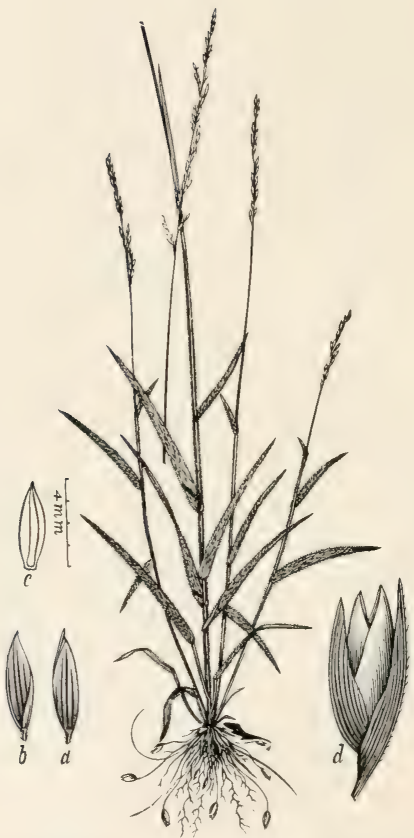

Fig. 32. Amphicarpon purshii kunth. Persil's Ampilcarpox.-An erect, tufted perenuial 3 to 12 dus. high, with hispid sheaths and leaves and contracted panicles. Fertile spikelets solItary and subterranean.-Pine barrens and ranberry bogs near the coast, New Jersey. August, September. 


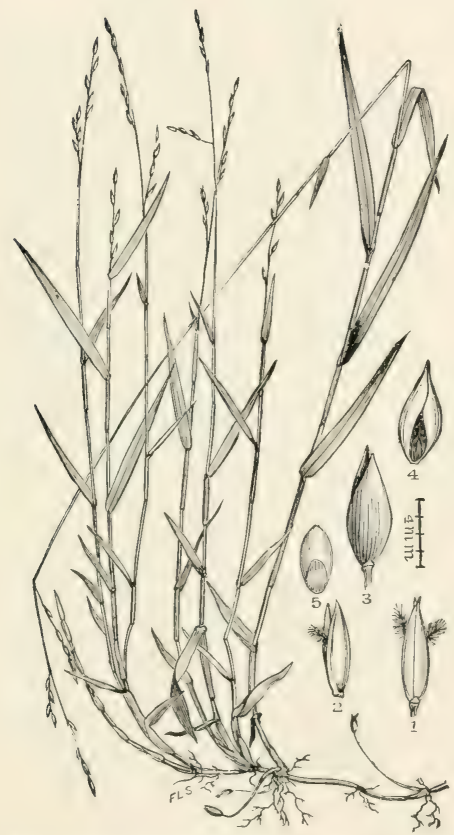

FIt, 33. Amphicarpon floridanum ('hapm.; Beal, Grasses N. Am., 2: 160). Frolims Ampricamon.-A pale-green, smooth perennial 3 to 9 dm. high, from ereeping rootstorks, with llat leaves and narmow panicles 10 to 20 cm. long. Fertilespikelets on subteramean branches. - Moist pine barrens and sandy shores, Florida (throughout the State). July-September. 


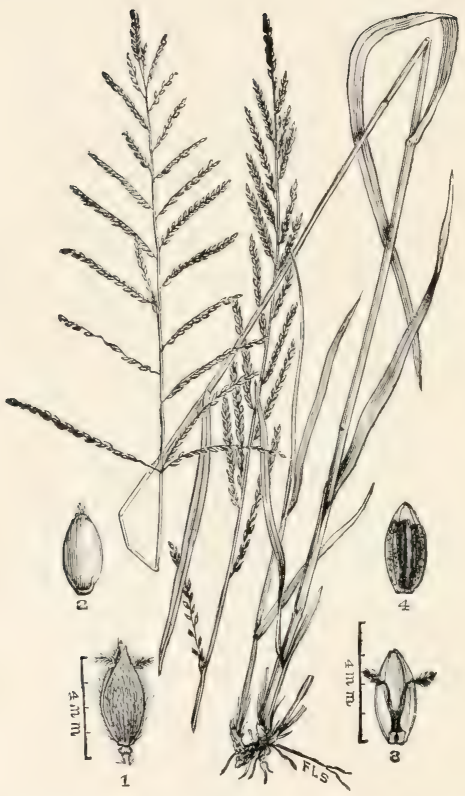

FIG. 34. Eriochloa mollis (Michx.) Kunth. (Panicum molle Michx.), Beal, Grasses N. Am., 2: 102. Solt Wool-Grass.-A perenuial 10 to $20 \mathrm{dm}$. high, with long, flat leaves and open panicles of numerous, more or less spreading racemes 3 to $6 \mathrm{~cm}$. long.-Brackish marshes and shores, south Carolina to Florida. April-September. 


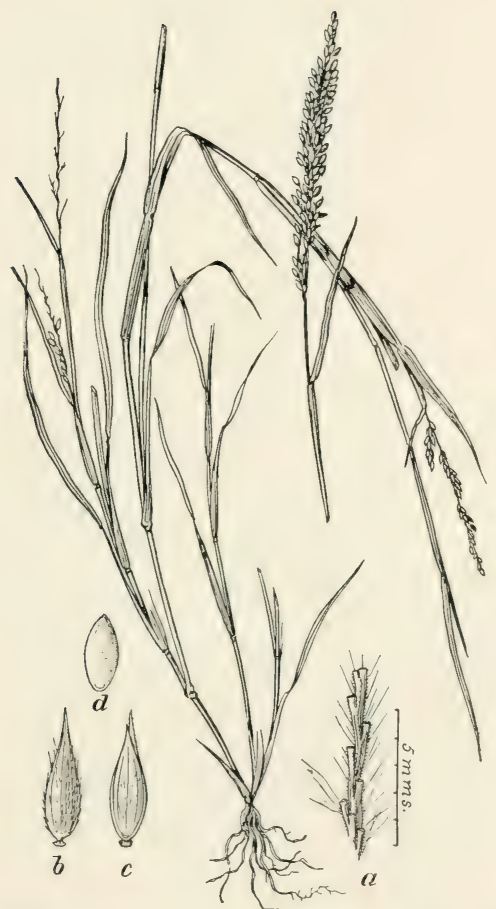

I'I(. 35. Eriochloa punctata (L.) W. IIamilt. EvelrastingGrisi.-A rapid-growing, smooth and somewhat sucenlent perennial, with more or less branching colms 6 to 12 dm. high, llat leaves amb narrow panicles 5 to $10 \mathrm{~cm}$. long.-Iow, rich land, moist soil, prairies, ete., Kansas to Texas and Arizona. [Tropical] Ameriea, Asia, and Australia.] June-September. 


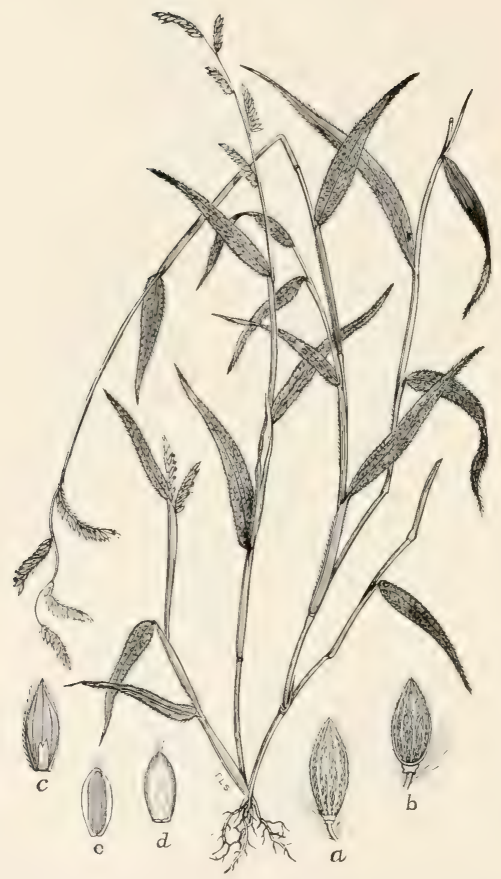

Fui, 36. Eriochloa lemmoni Vasey of Seribn, ; Real, (irasses N. Am., 2 : 101. Lemiox's Wool-Gis.ss.-A softly pubescent perennial 3 to $6 \mathrm{dm}$. high, with rather hroad leaves and a short panicle composed of about 6 sprearling spikes 2 to $3 \mathrm{em}$. long.-Arizona. [Northern Mexico.] Angust-November. 


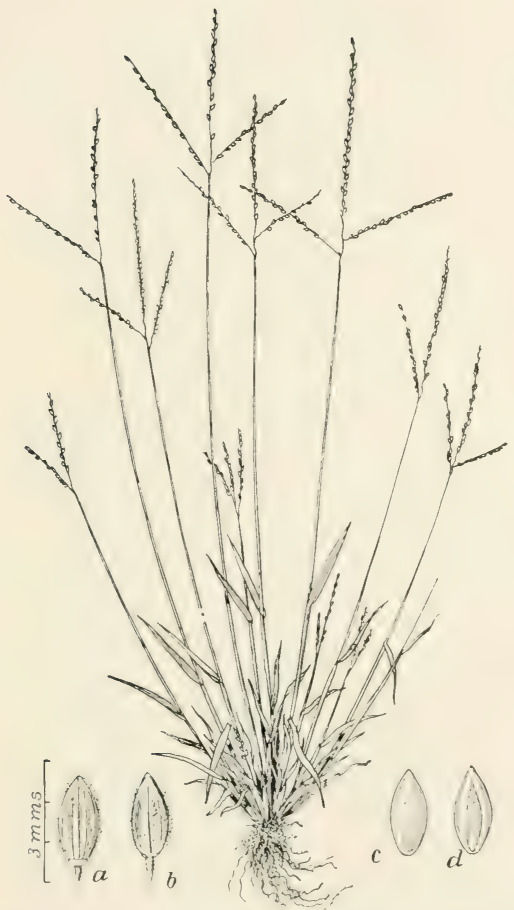

Frg. 37. Panicum lineare Krock (Panimu glubrum Ganul.; Syntherisma limearis Nash). Smootil Cram-gisass.-A slemder, glathrous annual 1.5 to $3.5 \mathrm{dm}$. high, with enlms which are muth branched below, llat leaves, and 2 to 6 slender diverging spikes.Xaturalized in waste and cultivated land; Nova ficotia to ()ntario and fouth Dakota, sonth to Floridand'Texas. [Europe.] AngustOctober. 


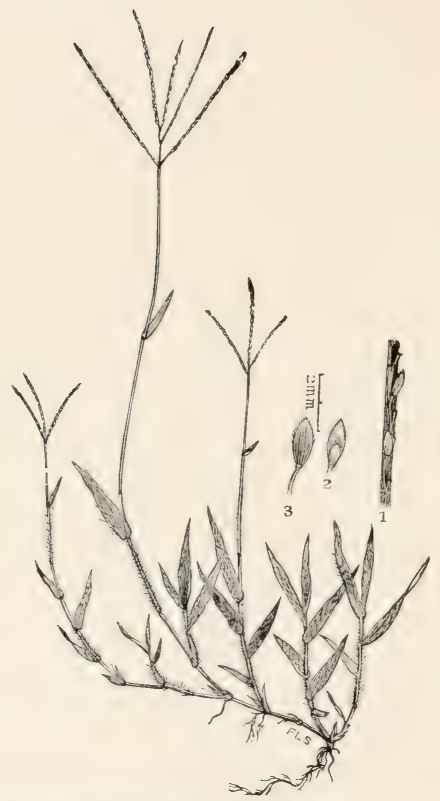

FIG. 38. Panicum serotinum (Walt.) Trin. (Syntherisma serotina Walt.; Digitaria serotina Mx.). Little Crab-Grass.-An extensively creeping ammal or biennal, with flat, hairy leaves, and slender spikes digitate at the apex of the ascending eulms, which are 1 to $3 \mathrm{dm}$. high.-Low, sandy gromul, roadsiles, pastures, and cultivated fields near the coast, Delaware to Mississippi; on ballast at Philadelphia. June-August. 


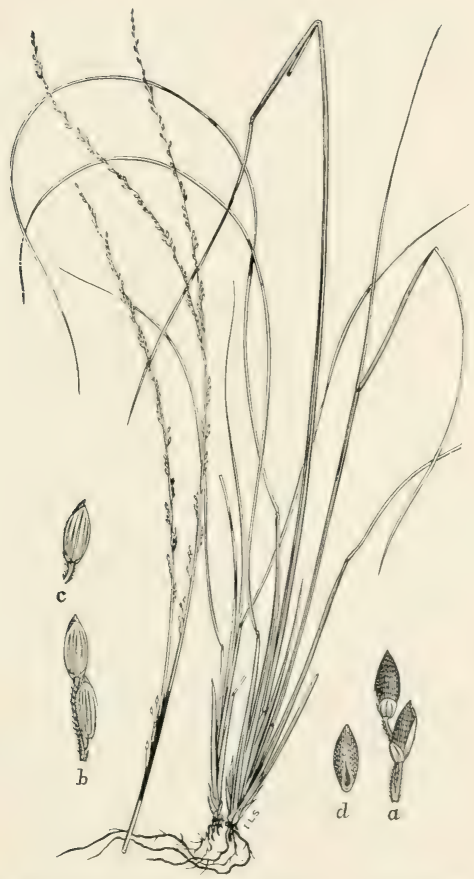

Fig. 39. Panicum gracillimum seriln, : Bnll. Torr. Bot. Cluh. 23: 146. Simpina l'uxicta.-A slender perennial 3 to 9 din. high, with very narrow, elongated leaves and small, glabrous spikelets, racemose along the main axis and its branches, which are approximate near the apex of the culm. Outer glumes glatbrous.-High pine lands, Lak ('onnty, Florida. (1192, Nash.) July. 


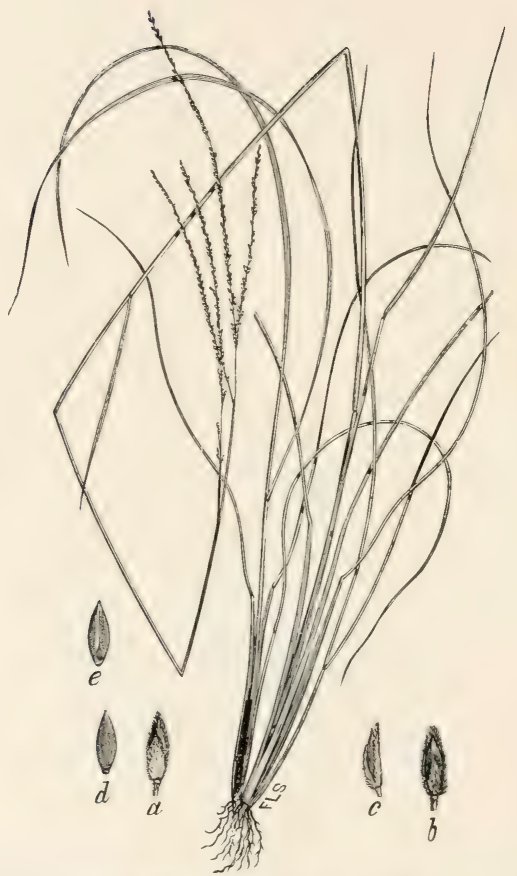

Ftr. 40. Panicum phæothrix Trin. Ap. (iram. Icon. 91. SnLVFry PANIC-diass.-A slemder perenuial about $9 \mathrm{dm}$. high, with long. narrow leaves and very sleuder, rather loosely flowered racemes 10 to $20 \mathrm{~cm}$. long, approximate near the apex of the 'ulm. ()nter glumes densely hairy.-High pine lands, Florida. (Nash, 1155.) [Brazil.] Julj. 


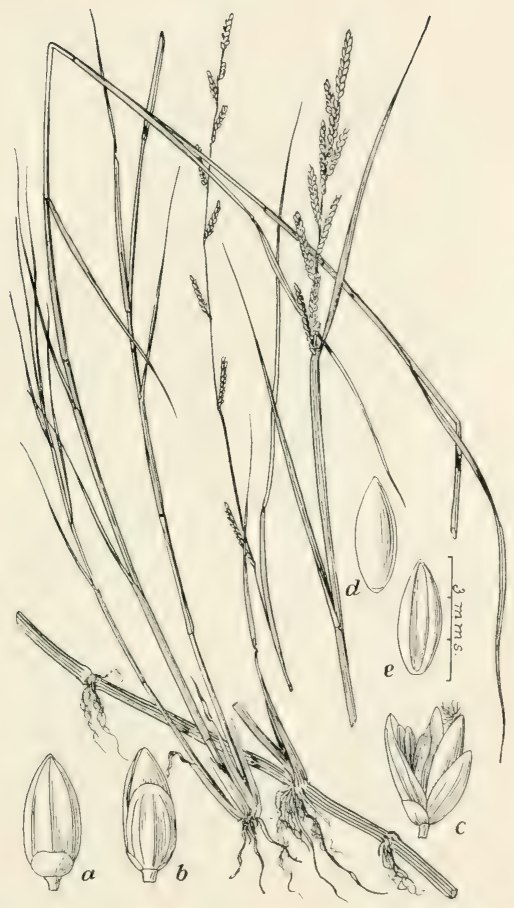

Fri. 41. Panicum paspaloides Pers.; Beal, Grasses N. Am., 2 : 114. Sorthris WATEk-cilass. - I riather stont, smooth, and more or less branching pereunial fi to $4 \mathrm{dm}$. high, often creeping at the base, with long, llat leaves, and ten to twenty alternate, one-sided spikes2 to: $10 \mathrm{~m}$. long. - 1 hont pouds and in standing water, sonthern Florida; Texas. [In tropical countries of hoth hemispheres.] May-July. 


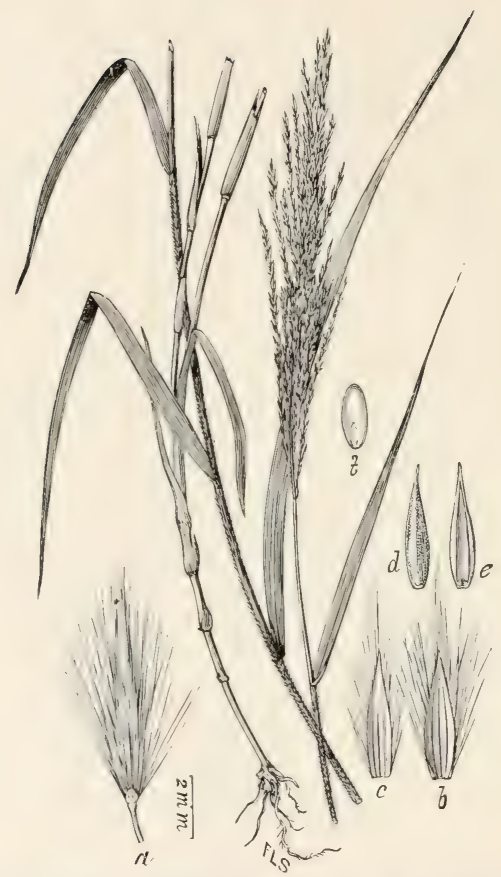

FIti. 42. Panicum lanatum Rottb. (P. leucoplecen HBK.); Beal, Grasses N. Am., 2: 111. Cotton-Grass.-A rather stout, more or less branching leafy prerennial 6 to $12 \mathrm{dm}$. high, with narrow, soft-hairy panicles.-Cultivated ground, river bauks, and coral soil on keys, rentral and southern Florida; on ballast at Mobile, Ala. [Widely distributed in tropical Ameriea; Australia; Africa.] May-October. 


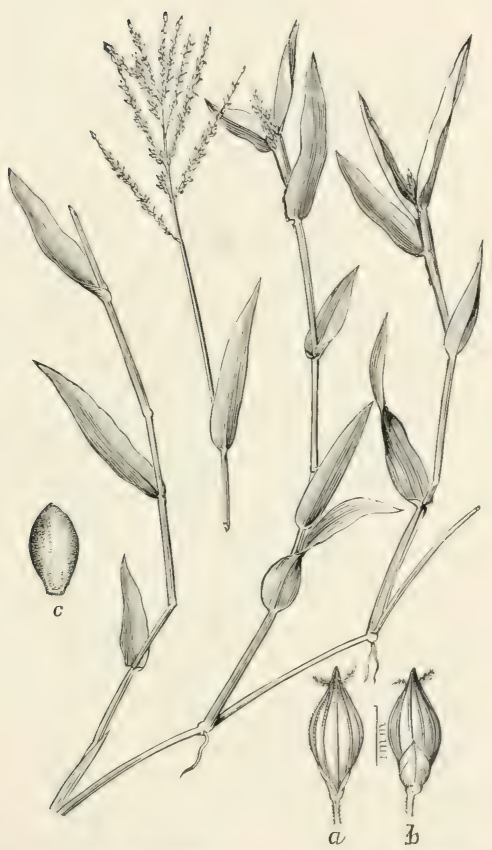

Fig. 43. Panicum grossarium L.: Beal, Grasses X. Iı.. 2 : 116. JAMAICA C'RAls-(rlissis.-Ipparently an anmut, with muchbranched, ascending ' nhos 3 to $6 \mathrm{dm}$. long, broad, lanceolate leaves and spreading panicles of a few simple racemes of glabrous spikelet.--Ballast ground, Philadelphia. Arlventive. [West Indies.] Septemher. ('ultivated in grass garlen, and appareutly valuable. 


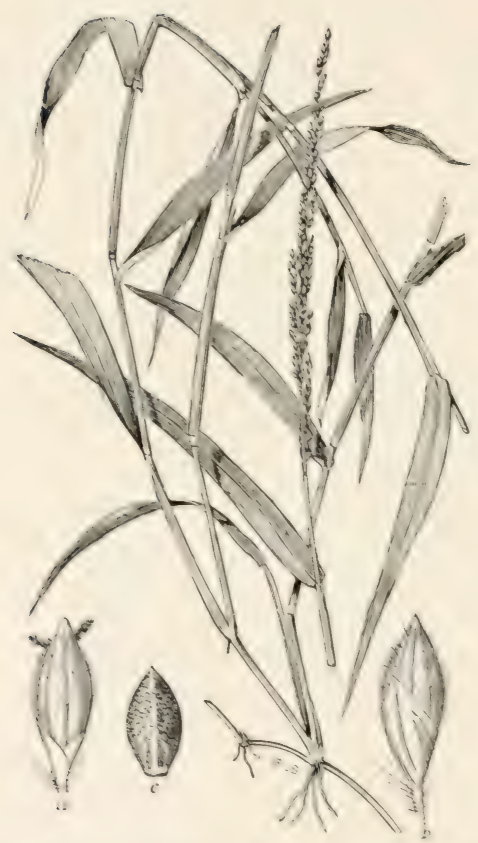

Fic. H. Panicum texanum luckl, Beal, Grasses X. Auı.,

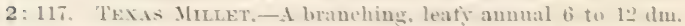
high, with that leaves and narrow panivles 1.5 to 2 dm. long... lexas. september. 


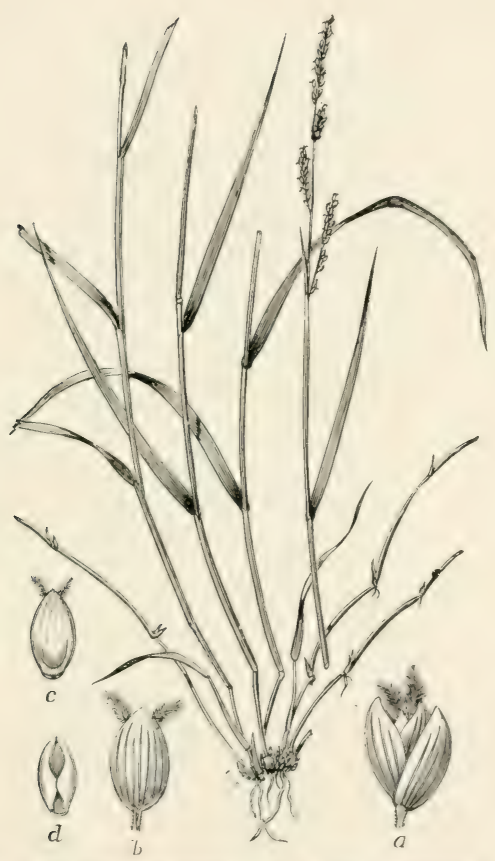

Fig. 15. Panicum obtusum HBK.; Beal, (irasies X. Am.. 2 :

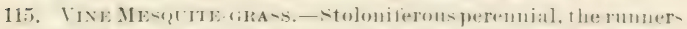
often 24 to :30 dun. long; the upright llowering hranches 3 to di dus. high. Panicle of three to five erect racemes, bearing rather large olituse sprikelets. - Irrigated Jands, Jow valleys, rhiefly in the shatle of trees and shrnbs, liansas and ('olorado to Texas. Jew Mexico, Arizona, and southwari. June-September. 


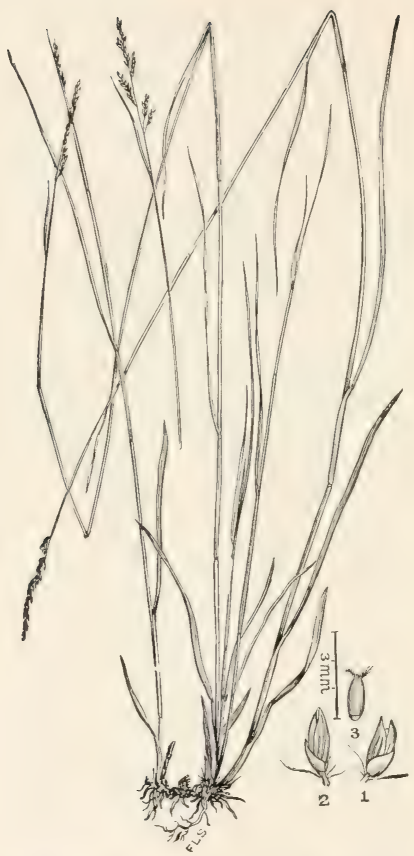

FIr. 46. Panicum stenodes Griseb. ( $P$. anceps strictum Chapm.); Beal, Grasses X. Am., 2 : 126. Niald-Jolntem Panic-grass.-A slender, erect, glabrous perennial, with wiry stems 5 to $8 \mathrm{dm}$. high, rigid, involute leaves, and narrow, simple panicles 4 to $8 \mathrm{~cm}$. long.-Moist, sanly pine barrens near the coast, Florida to Texas. [Cuba and San Domingo.] July-October. 


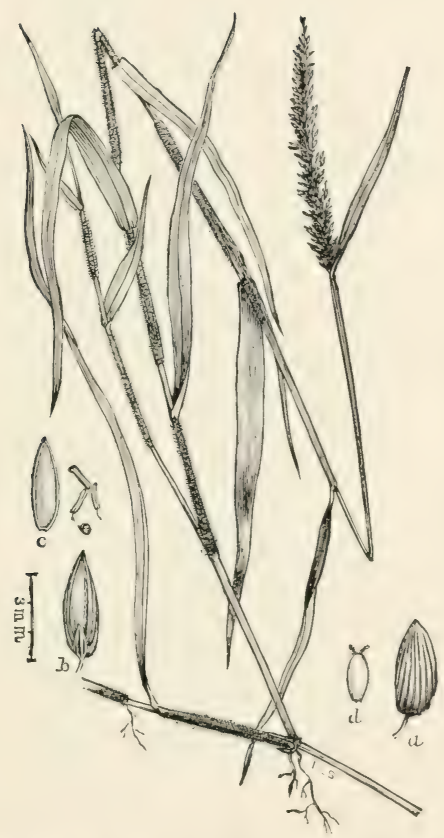

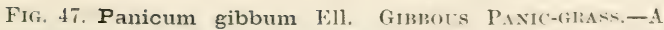
stoloniferous, branching peremmal 3 to 9 dm. high, with narrowly lancenlate, flat leaves, and densely flowered spike-like panicles 10 (1) 15 em. long. - Low, wet gromols, Virginia to Florida, Trunesse. Louisiana, and Indian Territory. [C'ul,a.] June-Oetober.

$11162-$ No. 7 - 5 


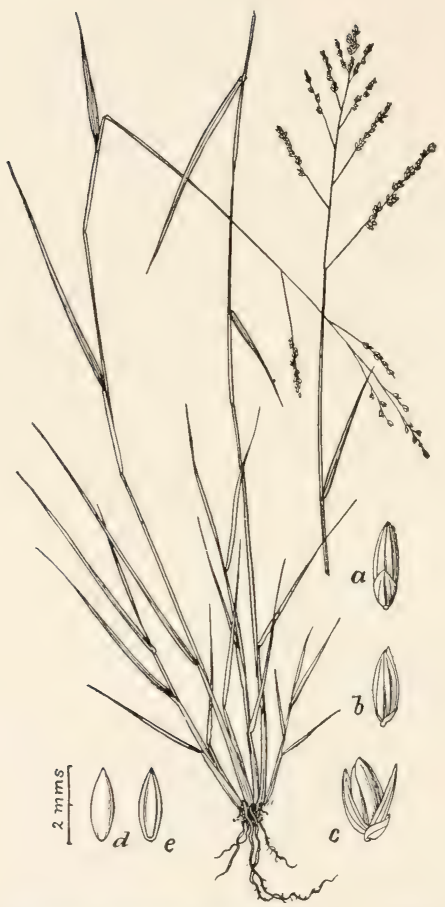

Fig. 48. Panicum melicarium Michx. ( $P$. hians Ell.); Beal, Grasses N. Am., 2 : 127.-A smooth, slender, usually ereet perennial 2 to $5 \mathrm{dm}$. high, with narrow, flat leaves and simple, open panicles 6 to $15 \mathrm{~cm}$. long.-Moist pine barrens and marshes. North Carolina to Florisla, Missouri, Indian Territory, and Texas. March-Oetober. 


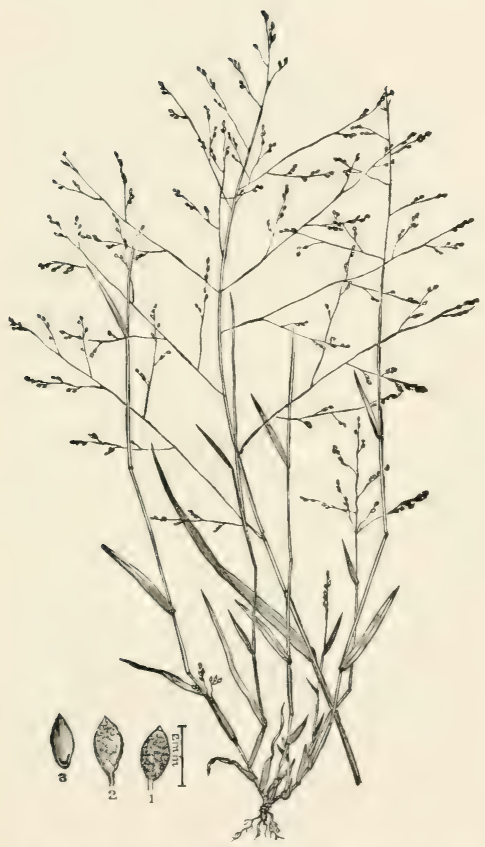

Fifr, 49. Panicum verrucosum Muhl. Warty P'ixic-firass.A slender, branching perennial, with flat leaves and fow-1lowered spreading panicles 7.5 to $20 \mathrm{~cm}$. long.-Low, rich woollands. mostly near the eoast. New England to Florida, west to Tennesseo and Louisiana. May-October. 
68

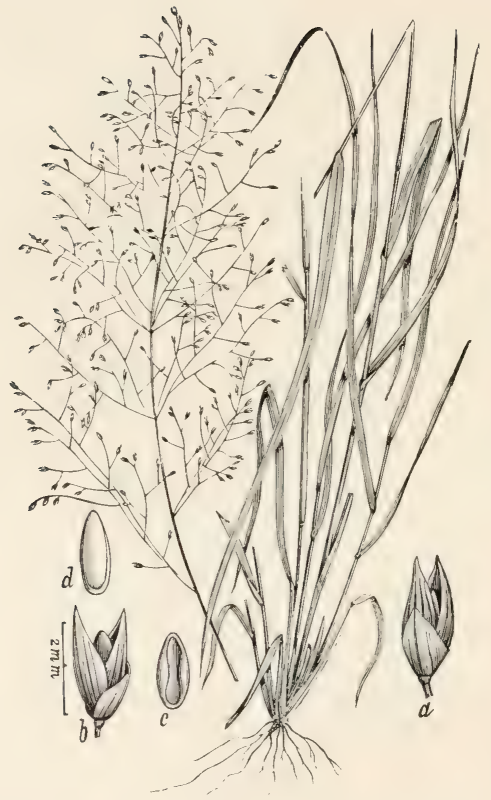

Fra. 50. Panicum filipes kcribn. in Heller, Contrib. Herl. Franklin \& Marshall Coll., I : 13 (18!15). - A slemler, more or less branching and leafy, glancous annnal (?) 3 to $7 \mathrm{dm}$. high, with rather long, flat leaves and diftuse capillary panicles 15 to $30 \mathrm{~cm}$. long.-Dry grounds, western Texas and (?) Mexico. May-July. 
69

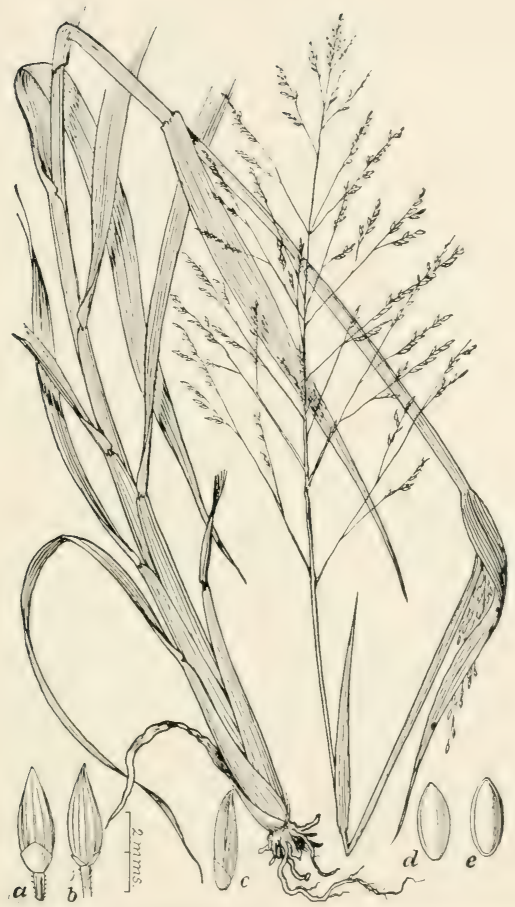

Fig.51. Panicum proliferum Lam. Splouting ('Rali-grass.i smooth and usually unch-branched, native annual, with rather roarse, spreading, or ascending stems ti to $18 \mathrm{dm}$. long, flat leaves and difine terminal and lateral pancles.-Low gromml, ditehes, etc., Maine to Illinois and Vebraska, south to Florida and Texas. [Cuba]. March-October. 


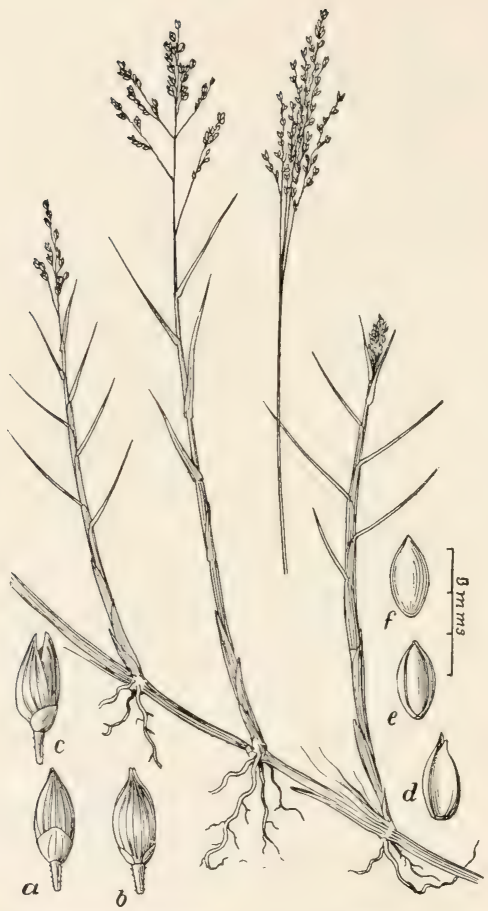

FiG. 52. Panicum repens L.; Beal, Grasses N. Am., 2: 127. Chefping PAxic.- In extensively creeping, maritime grass, with rather stitt leaves and rigid, upright, flowering stems or branches 2 to $5 \mathrm{dm}$. high.-Sea beaches, southern Aabama to Louisiana. [Tropical and subtropical cuasts of both hemispheres.] A good sand-binder. 


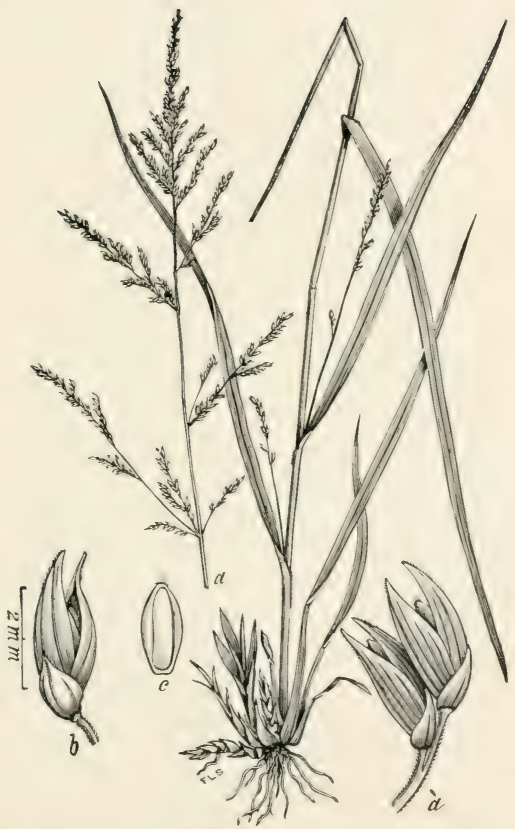

Fic. 53. Panicum anceps Michx. Flat-stmmed Panic.A rather stont perennial, with flattened stems 6 to 12 dm. high, long leaves, smooth or pilose sheaths, spreading panicles and pointed spikelets.-Low wools and thickets, marshes and hanks of streams, Pennsylvania to Illinois, Missonri, Iudian Territory, Texas, and Florida. July-October. 


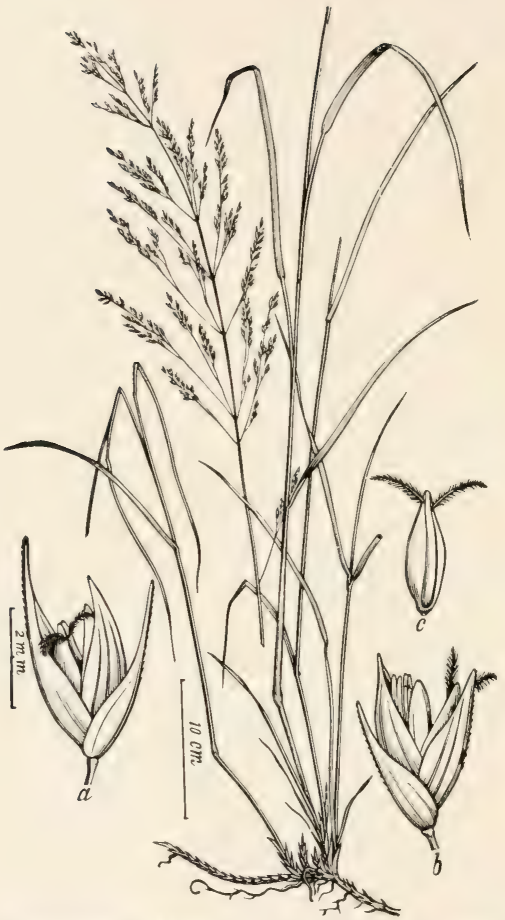

Fig. 54. Panicum virgatum L. SWitch-Grass. -A st out, erect perenuial 9 to $15 \mathrm{dm}$. high, usually forming large tufts, with strong, ereeping rootstocks, long, flat leaves, and ample, spreading panicles.-Sandy soil, usually aloug streams and ahout ponds and lakes, Maine and Ontario to North Dakota, Colorado, Arizona, Texas, and Florida. [Mexico.] July-Oetober. 


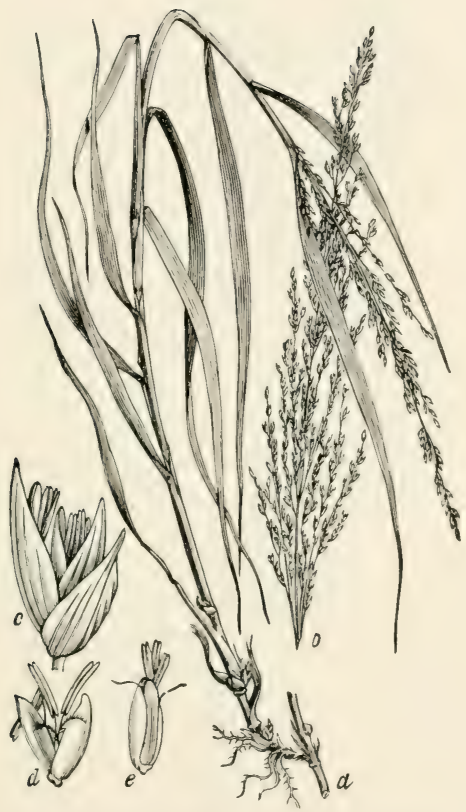

Fig. 55. Panicum amarum Ell. Bitter P'ANiC-dirass, - A stout. coarse perennial 3 to 12 $\mathrm{dm}$. high, from strong. creeping rootstork, with rather long (30 to $40 \mathrm{~cm}$.), rigid leaves and many-flowered, open panicles 10 to $30 \mathrm{~cm}$. long. - Sandy beaches, coast of sonthern New England to southern Florida. July-November. A good sand binder. 


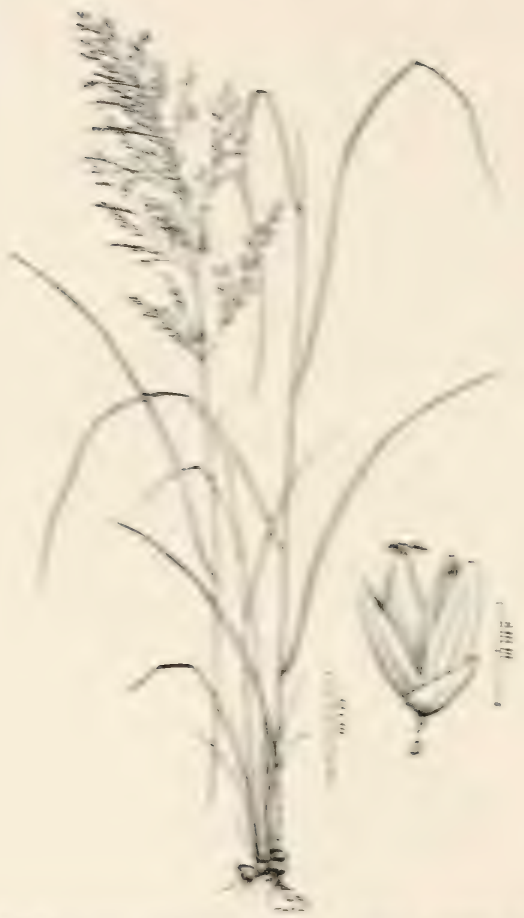

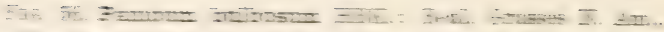

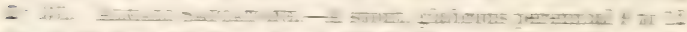

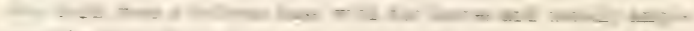

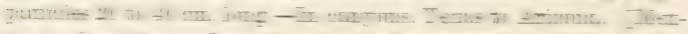

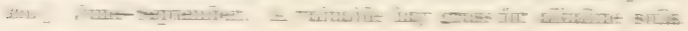




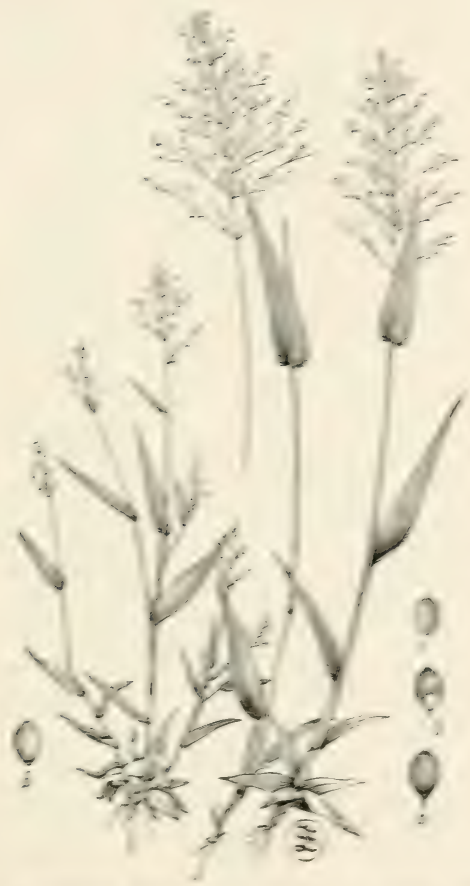

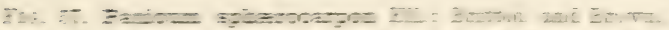

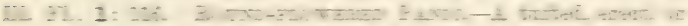

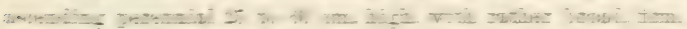

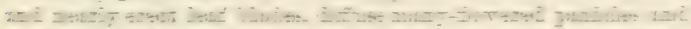

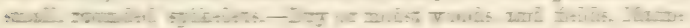

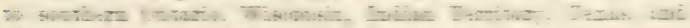

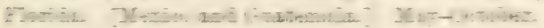




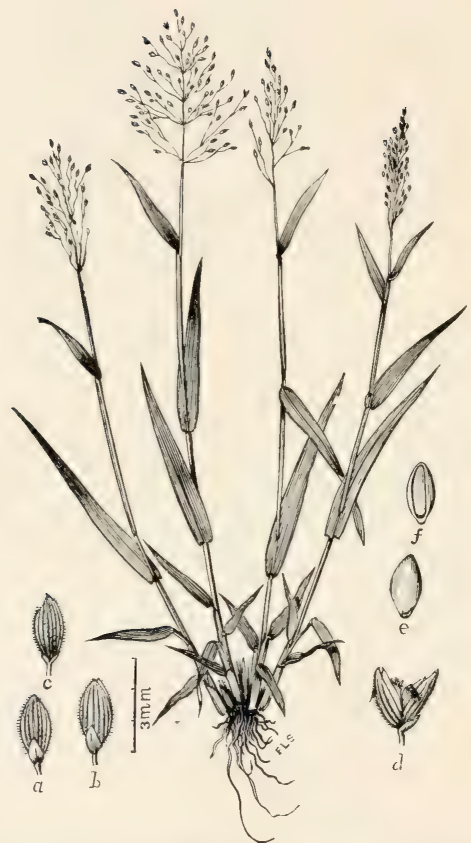

Fig. 5x. Panicum boreale Nash; Britton and Brown, Ill. Fl., 1: 119. Nonthens PANic-tikass.-An erect, finally branching perennial 3 to $6 \mathrm{dm}$. high, with llat leaves and open, spreading panicles 4 to $8 \mathrm{~cm}$. long.-Damp soil, Newfoundland and Ontario to Maine, New York, and Minnesota. June-August. 


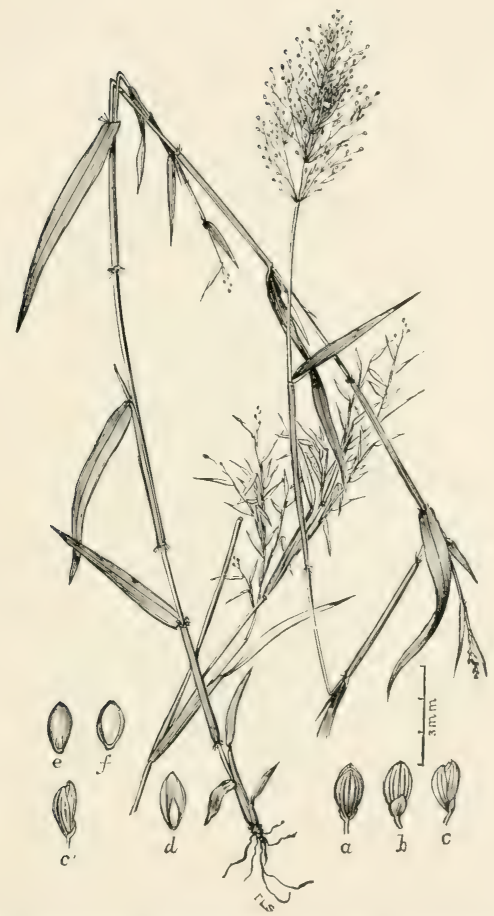

Fig. 59. Panicum barbulatum Michx. BFalnen-ionteCulns 3 to $9 \mathrm{dm}$. high, finally much-lvinched, slenter, smooth, except the nodes, which are conspicuonsly barbed with retlexed, white hairs, panicle ovate-pyramidal, spikelets numerous, small.Bogs, wet meadows, and low woodlands, southern Now York to Illinois, Florida, and New Mexico. 


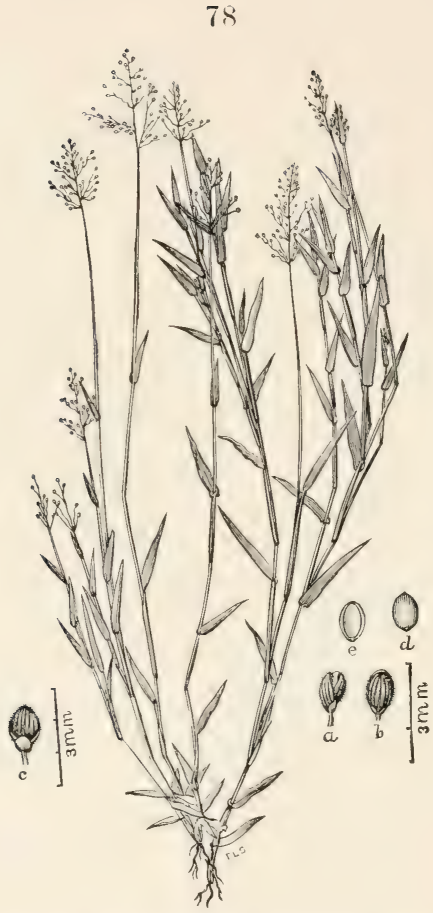

Fig. 60. Panicum columbianum seribn. sp. nov. American Panic-disass. - A sleucler, erent, much-brancherl, pubescent or glabrous pereunial, with short (usually 3 to $4 \mathrm{~cm}$. long), lanceolate, ascending, acute leaves, and small-flowered, diffuse, oblong or subpyramidal panicles. Spike-lets about 2 mm. long. Branches finally erect, numerons, flower-bearing.-Dry, sandy fields, meadows, aud open woodlands, Niw England southward to the Carolinas, and westward to Temessee and .labama, mostly near the coast; also in California. June-August. 


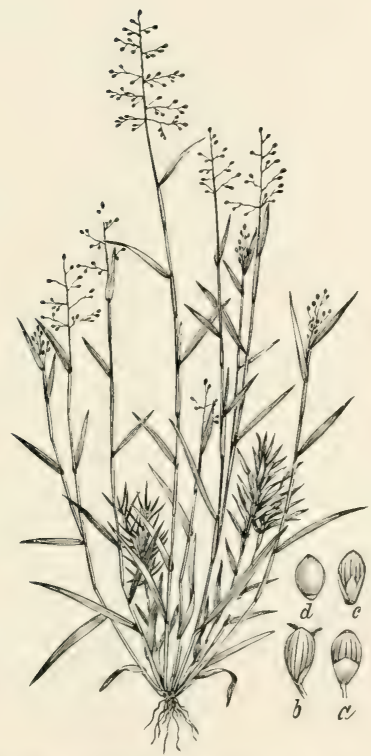

Fif. 61. Panicum nashianum Serilon. 8p). nov. (alliesl to $I$ '. demissum Trin.). NAsn's PANU-(ildsis.-A slender and finally much-hranched, leafy perennial 1 to $3.5 \mathrm{dm}$. high, with llat and rather short leaves, which are ciliate on the margins towarl the base, and open pyramidal panicles, the flexnose hranches widely spreading or reflexed. (1,029) ('urtis. (1893), aml 466 Natsh (1894), )Low pine barrens, often in moist gromul, near the coist, Virginia to Mississippi. [Brazil.] March-October. 


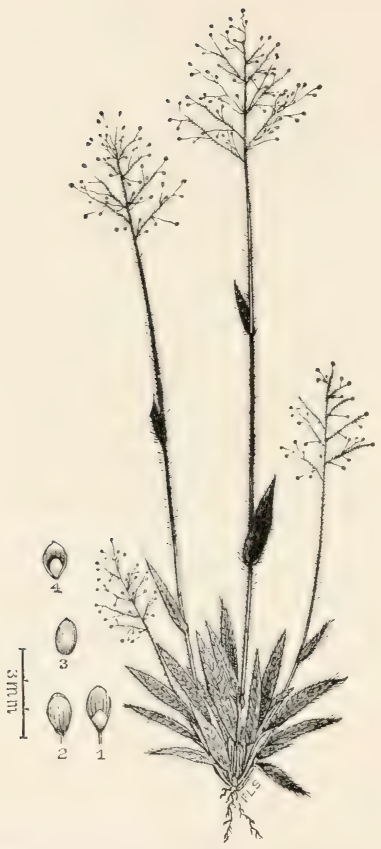

FIr. 62. Panicum longipedunculatum Seriln.; Bull. Tenn. Agr. Exp. Ntation, VII, $1: 53$. Loxg-stalien Paxic:-A slemiler, caspitose perennial 1.5 to $3 \mathrm{dm}$. high, with short, ehiefly ratical, pilose leaves and diffuse, small-flowered, long-exserted, hairy panicles.-Dry or moist pine barrens aud damp woods, apparently rare, eastern Tennessee to eastern North Carolina and Florida. May-August. 


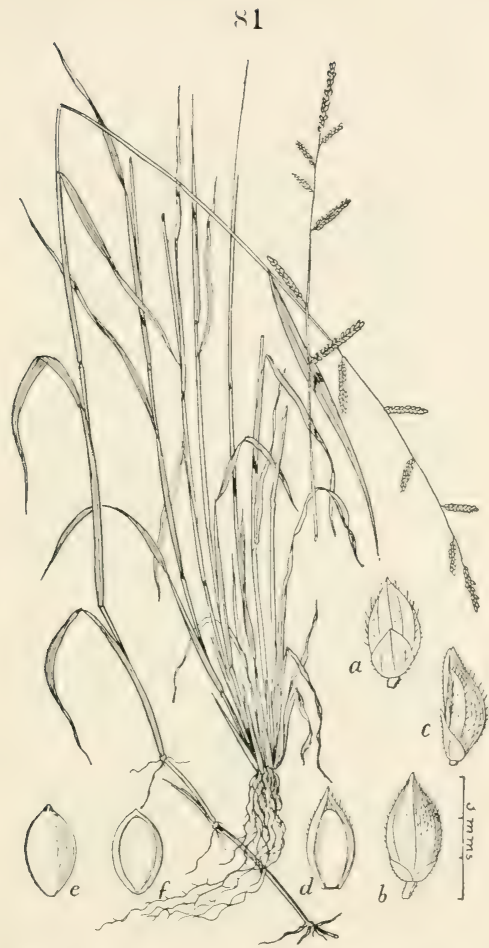

FIG. 63. Panicum colonum I. JinciLE RICE.-An erect or ascending, more or less branching anmual 3 to 6 dun, high, wiht flat leaves and five to ten, densely flowered, one-sided spikes, 1 to $3 \mathrm{~cm}$. long, racemose along the main axis.-bitches and low ground, southeastern Virginia and Tennessee to Florida, Texas, and southern (alifornia. [Widely distributed in tropical and subtropical regions of the Old World.] June-Oetober.

$$
11162-\text { No. } 7-6
$$




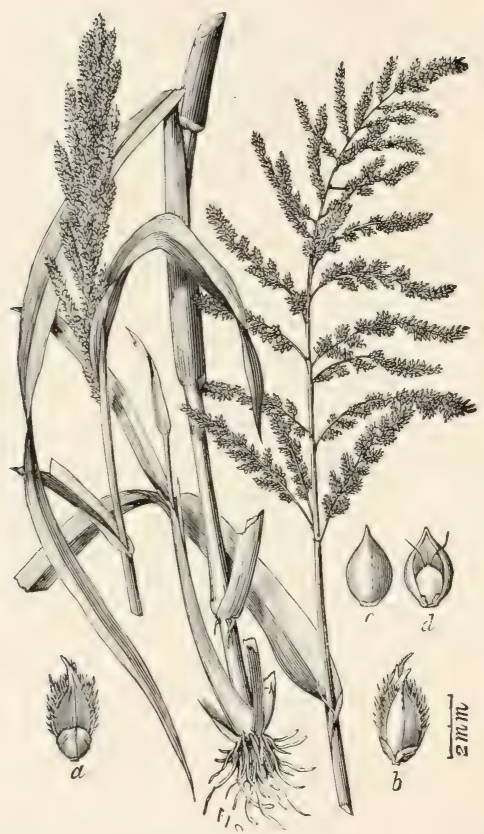

Fig. 64. Panicum crus-galli L. Barnyard-grass.-A coarbe, ascending or erect, leafy annual : to $15 \mathrm{dm}$. high, with dense pan1cles and with the third glume awnless to long-awned.--Alumst everywere in the United States in barnyards, waste ground, and river banks. Thronghout the warmer regions of both hemispheres. Flowers all summer. 


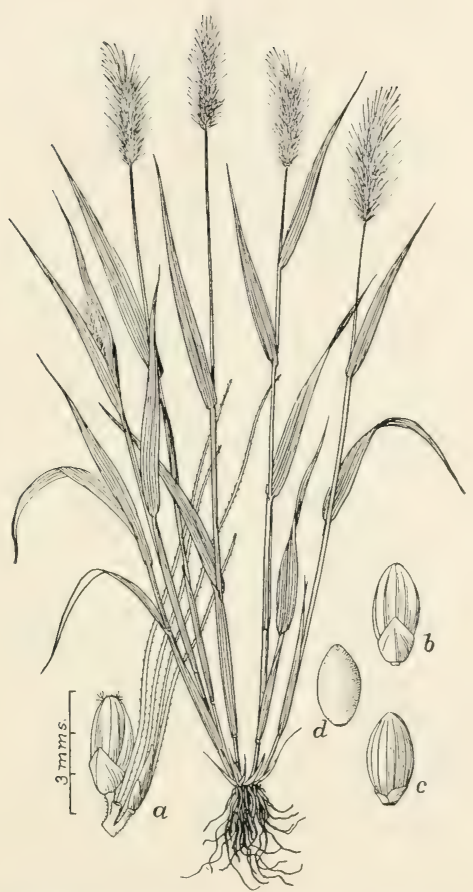

Firi. 65. Chetochloa viridis (L.) Seribn. (Panicum riride T...

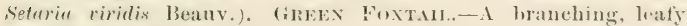
amnal 3 to $6 \mathrm{dm}$. high, with bristly, densely many-1lowered, spike-like panicles is to $10 \mathrm{~cm}$. lomg. Bristles nsually green and

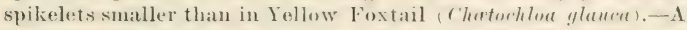
weol in multivated and waste grounds; naturalized from Europe. June-October. 


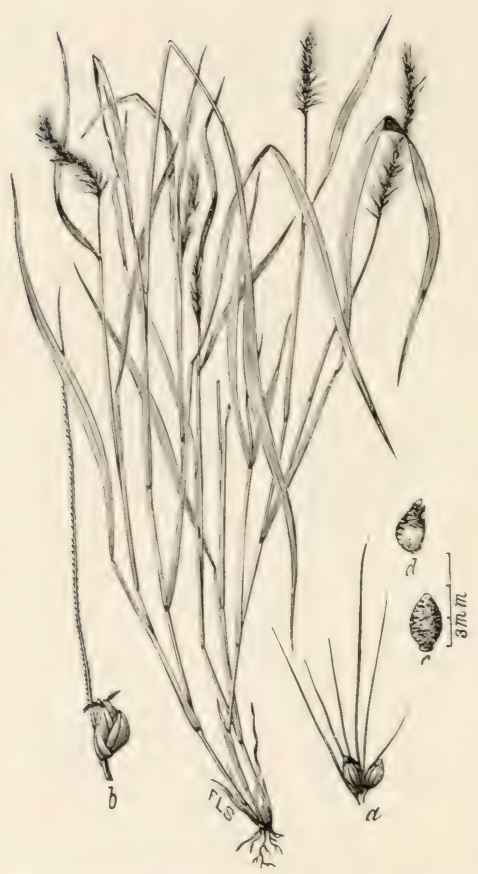

Fig. 66. Chretochloa corrugata (E11.) siriln. (Panicum corrugutum Ell.: Setaria corrugata Sibult.). Roctin Foxtst..-A rather slender annual 3 to 9 dun. high, wanally much hranched below, with llat leaves and bristly, spike-like panicles 3 to $10 \mathrm{~cm}$. longr.-Isually in enltivated land, feorgia and Florida. MayOctober. 


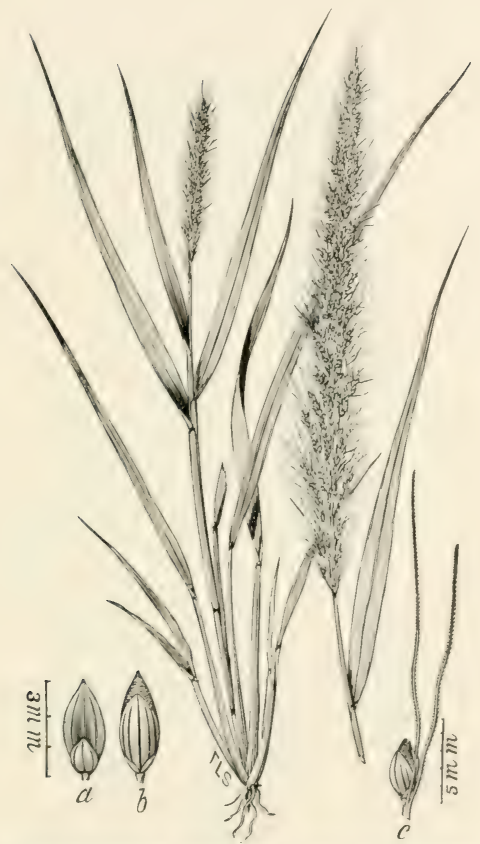

Fig. 67. Chæetochloa composita Seribn. (Seturia romposita

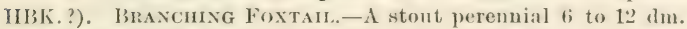
high, with broarl, flat leaves. and branching, hristly panicles 10 to 25.) r.m. long. Spikelets $33 \mathrm{~mm}$. long ; serond glume one-thiril shorter than the fourtlı. (No. 3617 , . 1. I. ('urtiss.) - Shell islands and leeys, sometimes in old pineapple fields, sonthern Florida. [West Iudies.] July-October. 


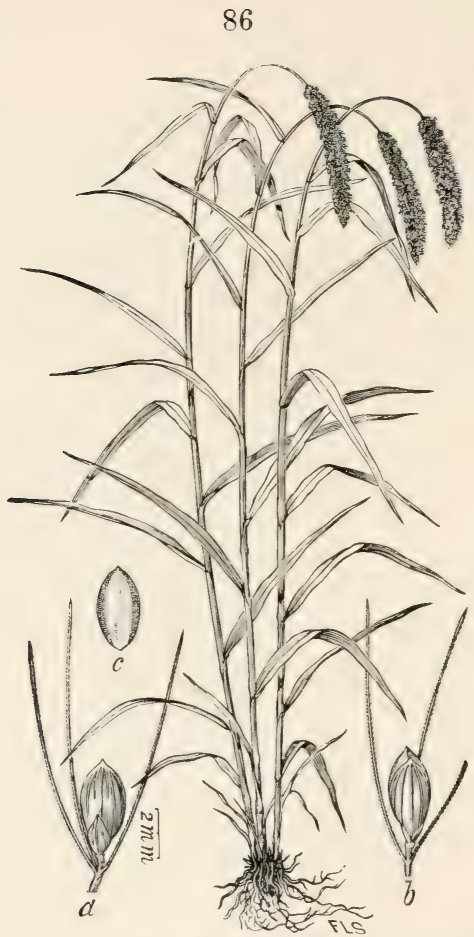

FIG, 68. Chætochloa italica (L.) Seribn. (Setaria italica Beauv.). Italian Millet or Huxgariax-grass.-A stout and rapitlly growing leafy anmul 10 to $24 \mathrm{dm}$. high, with large compound, nodding, hristly, and nearly eplindrical panieles 20 to 40 cm. long - In cultivated and waste land, eseaped from eultivation or adventive here and there throughout the country. [Europe, Asia.] July, August. 


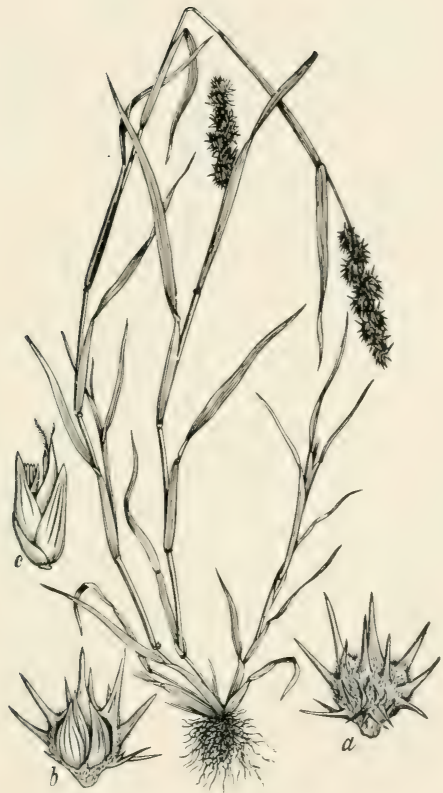

Fig. 69. Cenchrus tribuloides L. SANI Brr.-An amual, with spreading or ascending, much-branched, compressed culms usually about $3 \mathrm{dm}$. high, and terminal racemes, of 6 to 20 burlike involncres. - Samly tields, waste gromml, river lyanks, and sea beaches, Maine and Ontario to South Inakota and ('olorado, sonth to Florida and sonthern California. [Mexieo and sonth America.] June-Oetober. 
88

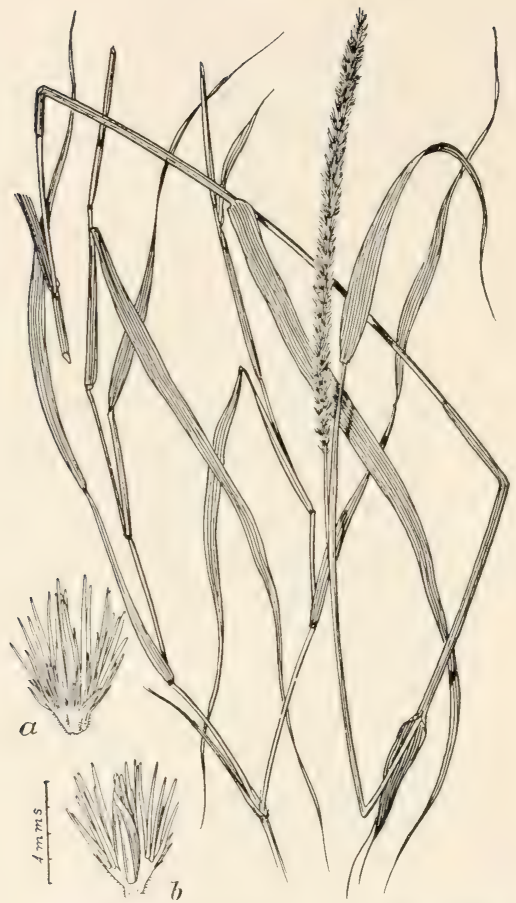

FiG. 70. Cenchrus myosuroides HBK.; Beal, Grasses N. Am., 2:160. LONG-SPIKED BCR-GRAss-A stout perennial 6 to $8 \mathrm{dm}$. high, more or less branching and geniculate below, with flat leaves and long, cylindrieal spikes 12 to $20 \mathrm{~cm}$. long. - Waste ground, introduced; southern Florida to Texas. [Mexico, South Ameriea.) Angust-January. 


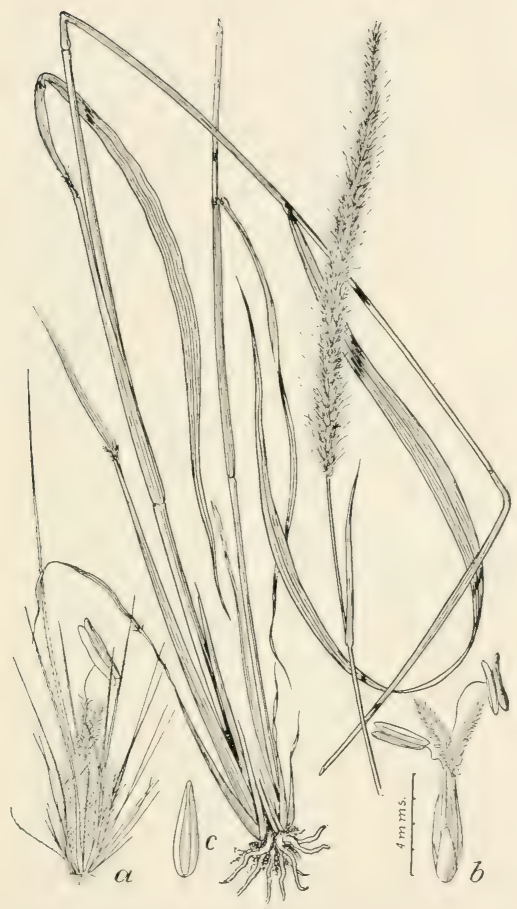

Frr. 71. Pennisetum setosum (Sw.) Rich.; Beal, Grasses N. Am., 2: 166.-A stout, branching perennial 9 to $12 \mathrm{dm}$. high, with flat leaves and dense, bristly, cylindrical spikes 10 to $15 \mathrm{~cm}$. long.- Southern Florida. [Widely distributed in tropical countries.] September. 


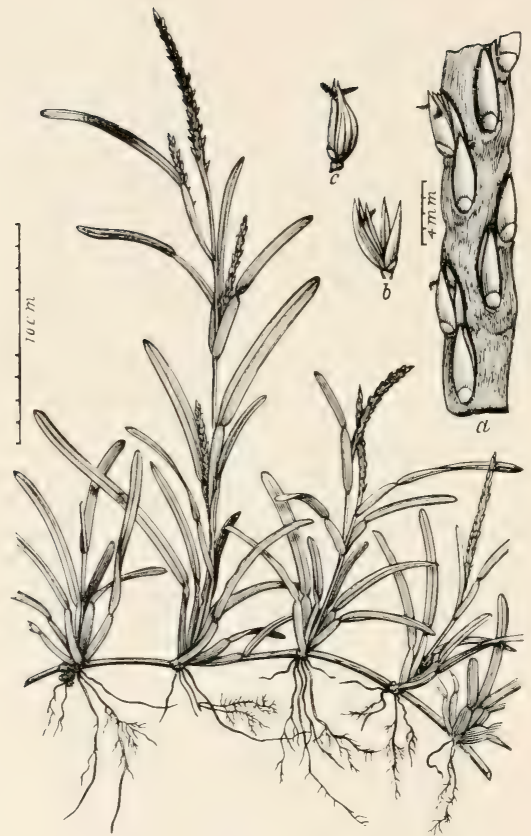

FIt: 72. Stenotaphrum secundatum (Walt.) Kuntze (Ischopmum sceundatum Walt.; Stenotaphrum americumum schrank.). Mision-filiss.-Extensively creeping peremial, with hard, flat stems, rather broad leaves, and upright, llowering stems 1.5 to 3 Am. high.-Muddy or moist samiy shores and marshes along the coast, Sonth Carolina to Florida and Louisiana. [Widely distributed in tropical Imeriea and the P'acifie islands.] April-october. 


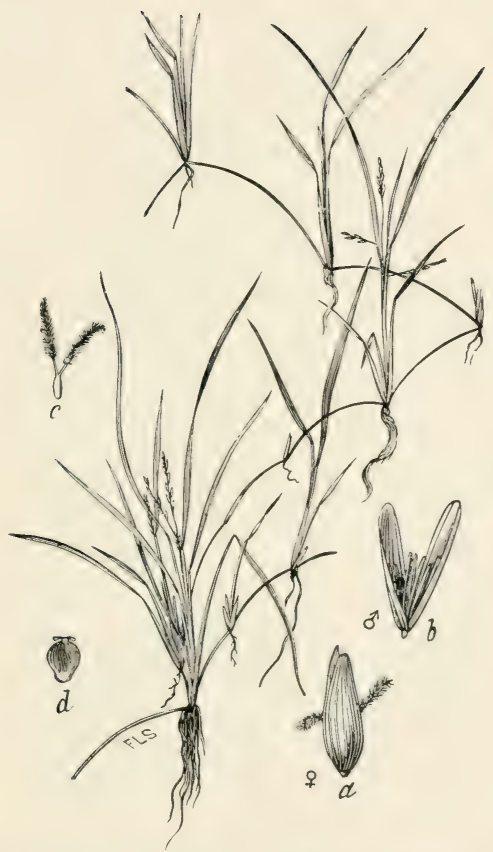

FIsi, 73. Luziola alabamensis ('hapm.; Beal, Grasses N. Am.. 2: 17.- - An aruatic, stoloniferous grass, the upright enlms 0.5 to 1.5 dm. high, with long, narrow leaves and the staminate and pistillate spikelets in separate panicles.-In springy places and rivulets in the pine barrens, nouthern Alabama [C'uba.] JuneOetober. 


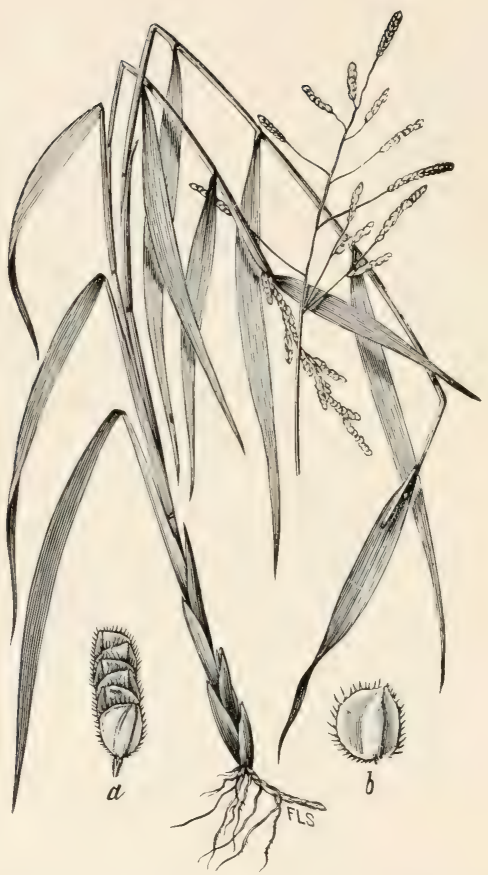

FIG. 74. Homalocenchruslenticularis (Michx.) Scribn. (Leersia lenticularis Michx.). CATCH-FLY-GRASs.-A rather stout, branching perennial 6 to $12 \mathrm{dm}$. high, with widely spreading, broad leaf blades, diffuse panicles, and large, ciliate spikelets.-Marshes and wet thickets, near the coast, Virginia to Texas, and in the Mississippi Valley from southern Illinois and Missouri to Louisiana. August, September. 


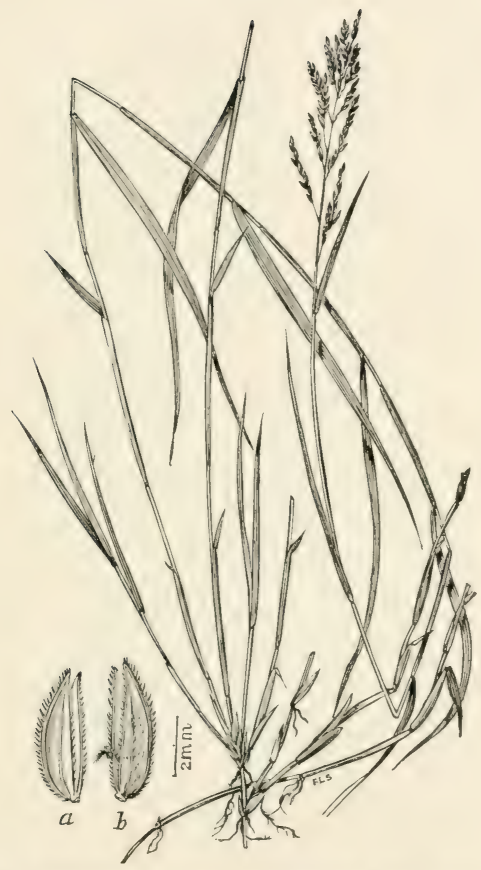

Fig. 75. Homalocenchrus hexandrus (Sw.) Britton; Beal Grasses N. Am., 1: 179 (Leersia hexaudra Sw.).-A rather slender, usually erect, hranching grass 6 to $12 \mathrm{dm}$. high, with narrow, many-flowered panicles 10 to $15 \mathrm{~cm}$. long.-In swamps and ditches near the coast, North Carolina to Florida and Texas. [In all tropical and many subtropical countries.] May-September. 


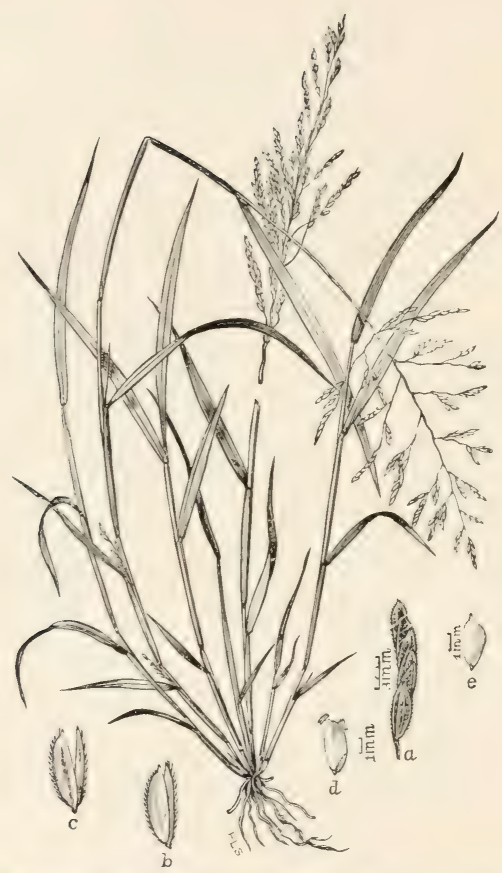

FI(i, 76. Homalocenchrus oryzoides (Nw.) I'oll. (Leersia ory-

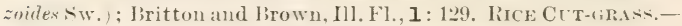
A rather stout, rough, and much-hrancleel grass 6 to $12 \mathrm{dm}$. high, with open, pale-green or straw-coloret panicles 12 to 2.) cm. long.Along streams and ditches and in marshes, nsually in the open. Cova reotia and Ontario to Washington, Florida, and Texas. [Europe and Asia.] Angust-October. 


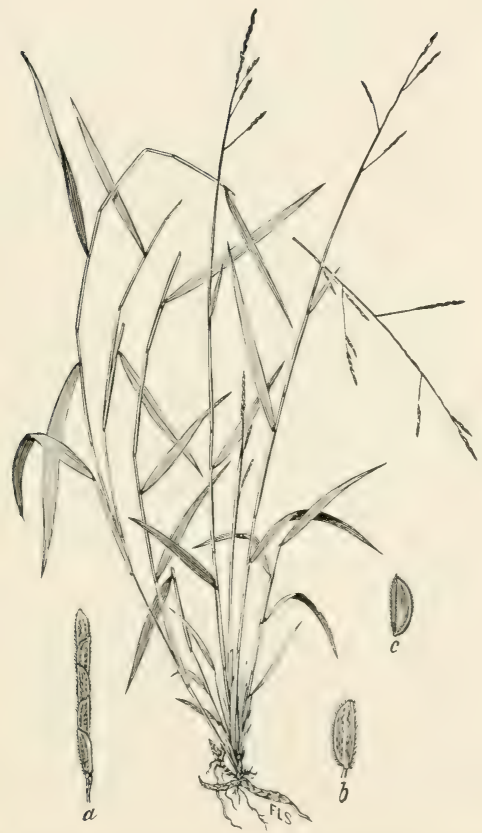

Fif. 77. Homalocenchrus virginicus (Willd,) Britton, (Lersia virginica Willd.). Wurte-disas.-A slender, erest, or aseending, usually much-brancherl, perennial 6 to 12 dm. high. with narrow leaves and simple panicles $x$ to 12 (-m). long.- Iloist thickets and low woods, uswally along streams, Maine and Ontario to fouth Dakota, southward to Florida, and Texas. May-octoher. 


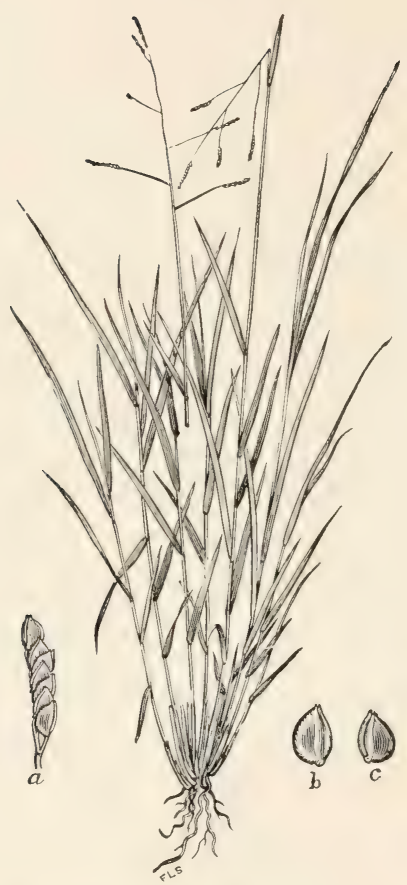

Fif. 78. Homalocenchrus monandrus (Sw.) Britton (Leersia monandra Sw.); Beal, Grasses N. Am., 2: 179. Sllender CuTGRAss.-A slenter, sparingly branched grass with somewhat wiry culms 3 to $6 \mathrm{dm}$. high, and nsually glaucous leaves.-Keys of sonth Florida (in coral soil) and in southeru Texas, [Mexico, West Indies, and south America.] February-May. 


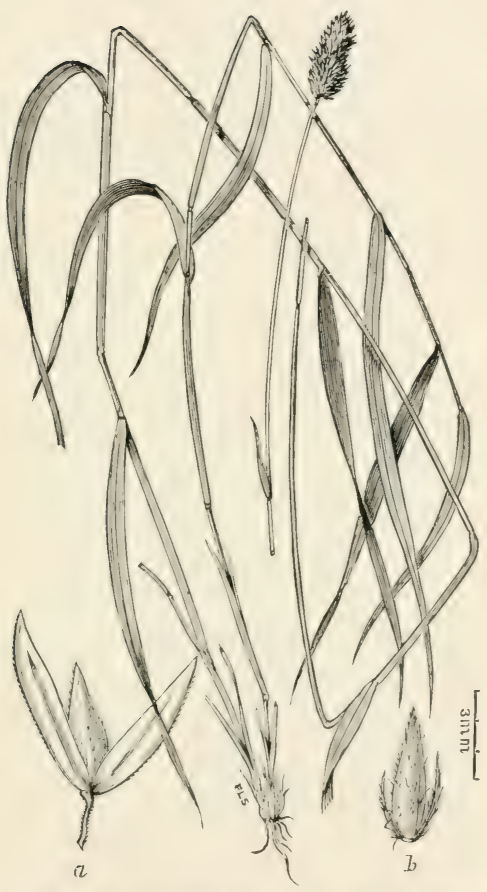

FIg. 79. Phalaris amethystina Trin.; Beal. (irasses N. Am., 2 : 18:3. Pirple Caxary-gimass.-A stout ammal 4 to 9 dm. high. with broad, flat leaves, and ovoid or ohlong, densely-flowered terminal panicles,-Oregon fo California and sonthward to Chile. June.

$11162-$ No. $7-7$ 


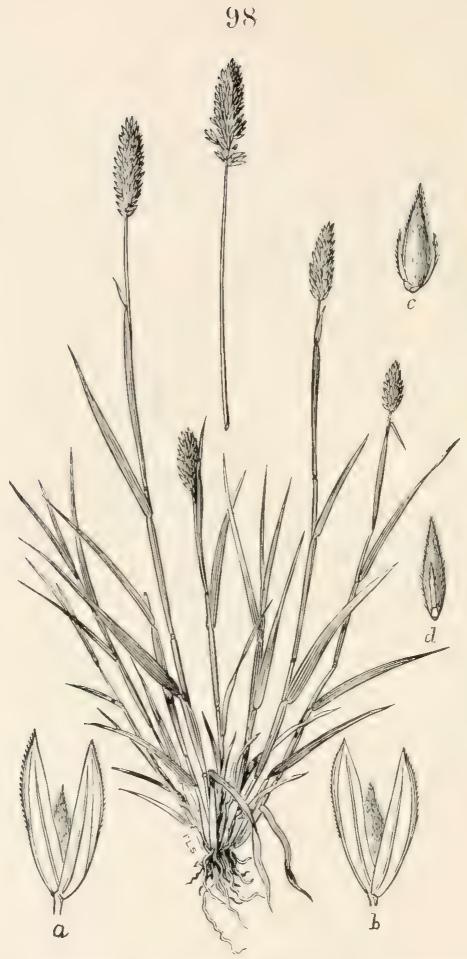

FIG. 80. Phalaris caroliniana Walt. ( $I$. intermedia Bose.). Sottherx Canary-dirass. - - 1 comparatively sleuder speries 3 to $6 \mathrm{dm}$. high, with rather short, flat leaves, and ovoid, deusely tlowered, cappitate panieles 2 to $5 \mathrm{~cm}$. long.-River bottoms and wet places, south Caroliua to Indian Territory, Texas, Nevada, California, and Oregon. April. 


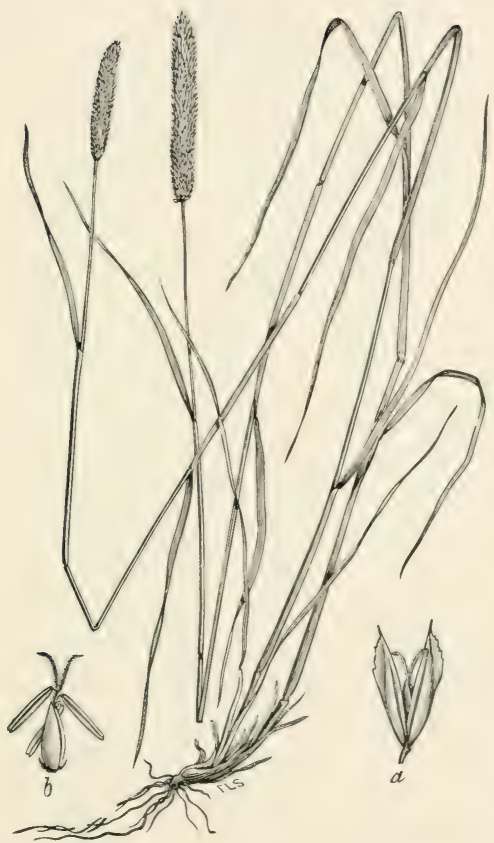

FIt, א1. Phalaris angusta Vees (I', intermediu angusta Chapmi.). Calforisa Truetry:--A stont grass 6 to $11 \mathrm{dm}$. high, with nar. row, densely flowered, spike-like panicles 6 to 12 em. long.-In wet places, fouth C'arolina and Lousiana to southern f'alifornia. [Nouth America.] May. C'ultivated to a limited extent in the Southern States. 


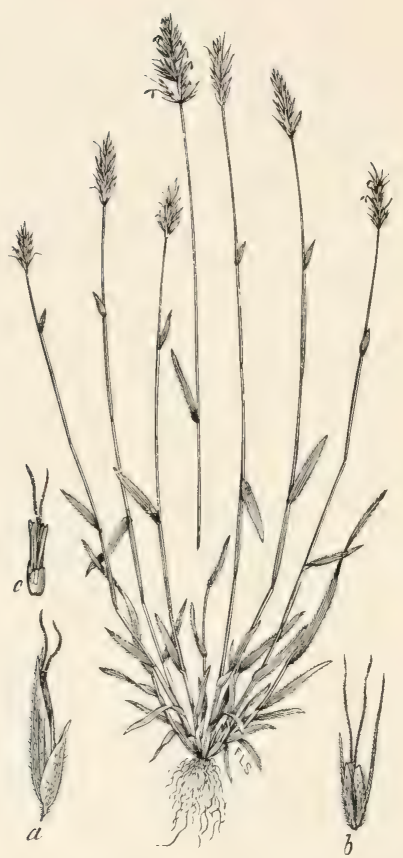

Fifi. 82. Anthoxanthum odoratum I. sWEET VErxaIGliss.-A sweet-scented grass, with slender, erect, tufted culms, flat leaf-blades and narrow, spike-like terminal panicles.-Aloundantly naturalized in lawns, fields, and waysides from Newfoundland and Ontario to North Carolina and Tennessee. [Europe, northwestern Asia, and northern Africa.] May-September. 


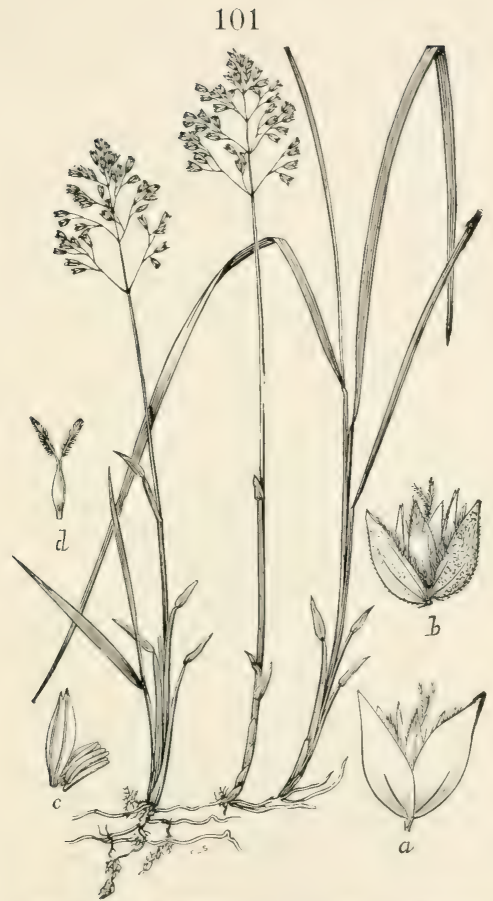

Fig. 83. Savastana odorata (L.) Sieribu. (Hierochloë borealis R. AS, ). VAxul.t-cilass.-A slender, sweet-scented, stoloniferous perennial 3 to $f \mathrm{dm}$. high, with short culm-leaves and brownish, open panicles. The flat leaves of the sterile shoots are 1 to 3 in. long.--New foumdland and New Brunswick to sonthern New York, west to Minnesota and Iowa; in the Rockies from British America south to Arizona and Mexico; Alaska southward in tho mountains to Orecon. [cooler temperate regions and high mountains of hoth hemispheres.] April-August. 


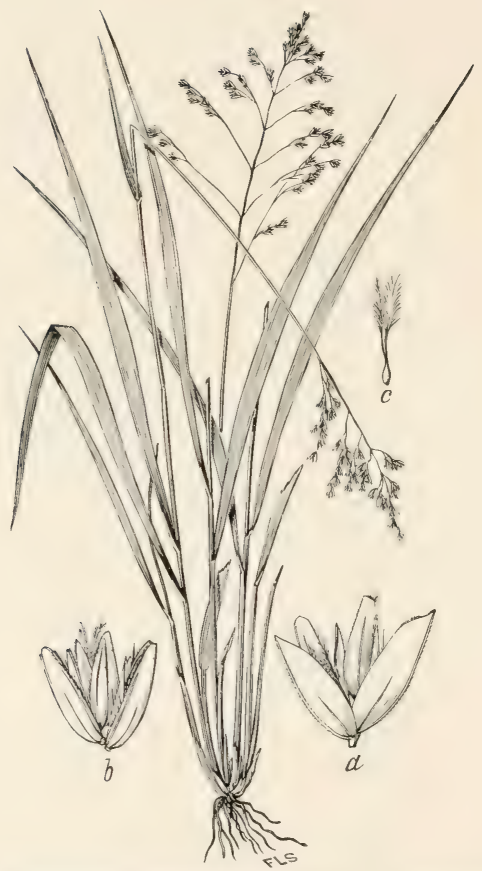

Fig. 81. Savastana macrophylla (Thurb.) (Hierochlö̈ macrophylla Thurb.); Beal, Grasses N. Am., 2: 187. Large-LeafeD VAxili-g-Giss. - A rather stout, native peremial 6 to $10 \mathrm{dm}$. high, with long and broad leaves and loosely flowered panicles. usually ahout 4 inches long.-Coniferous woods, California and Oregon. 'areh-May. 


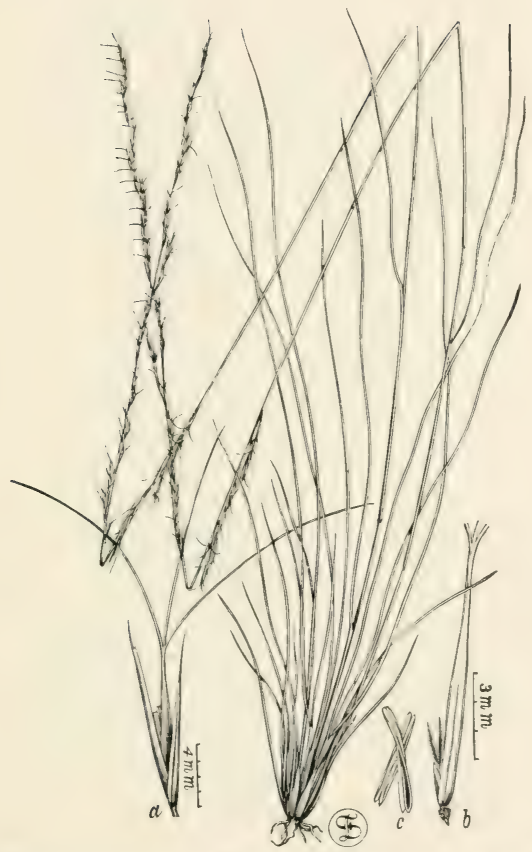

FIti, 85. Aristida stricta Miehx. WIItE-1iRAss,-A rigid, erect wiry perennial 6 to $12 \mathrm{dm}$. high, with narrow, involute leares and strict, spike-like panicles about $30 \mathrm{~cm}$. long.-Dry piue barrens near the coast, Virginia(?) and North ('arolina to Mississippi, wften covering extensive tracts aud forming the hulk of the pasturage. July-Oetober. 


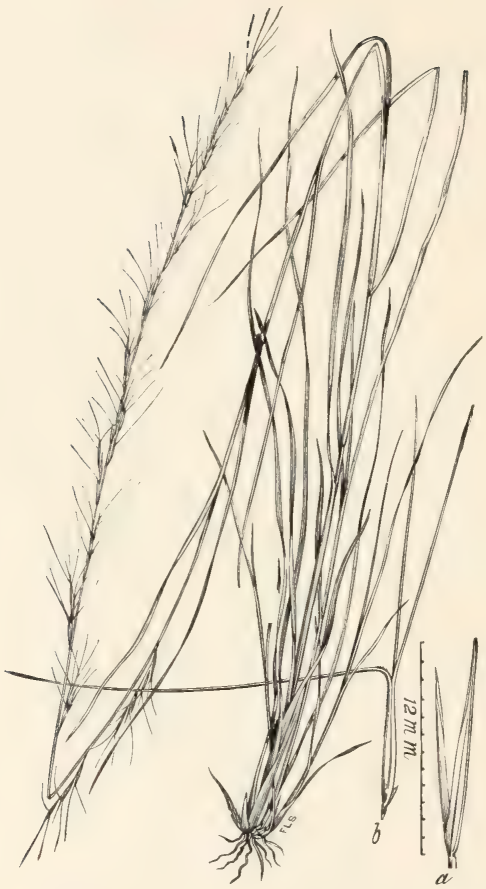

FIG, 86. Aristida palustris (Chapm, ) Vasey (A. virgata palustris Chapm.). SWAMP Poverty-grass.-An upright, rigid perennial 6 to $15 \mathrm{~cm}$. high, with long, narrow leaves, and sleuder, interrupted, spicate panicles 30 to $70 \mathrm{~cm}$. long.-Moist places near the coast in the pine barrens, Sonth Carolina to Texas. [Cuba.] August-Oetober. 


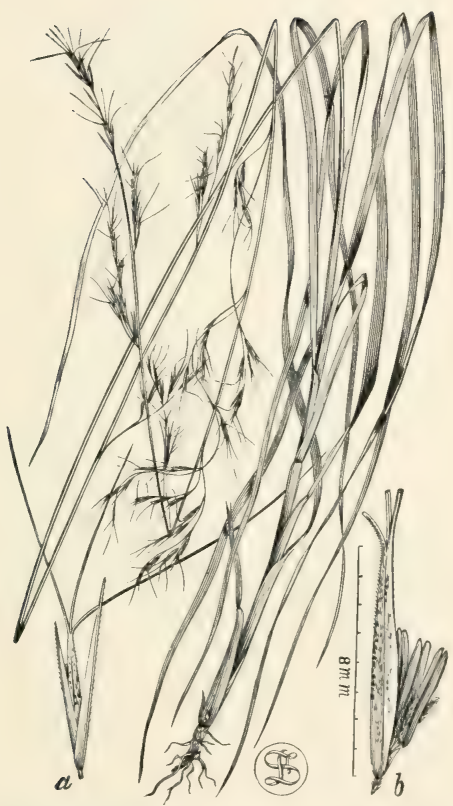

FIr. 87. Aristida gossypina Bose (A. lanate Poir.). Woor. I'OVERTY-grass. - A rather stout perenuial, with simple stems 6 to $12 \mathrm{dm}$. high, and narrow panicles 30 to $60 \mathrm{em}$. long. Lower sheaths usually wooly.- Dry pine barrens, mostly near the coast, Delaware to Texas and Indian Territory. Septemler-November. 


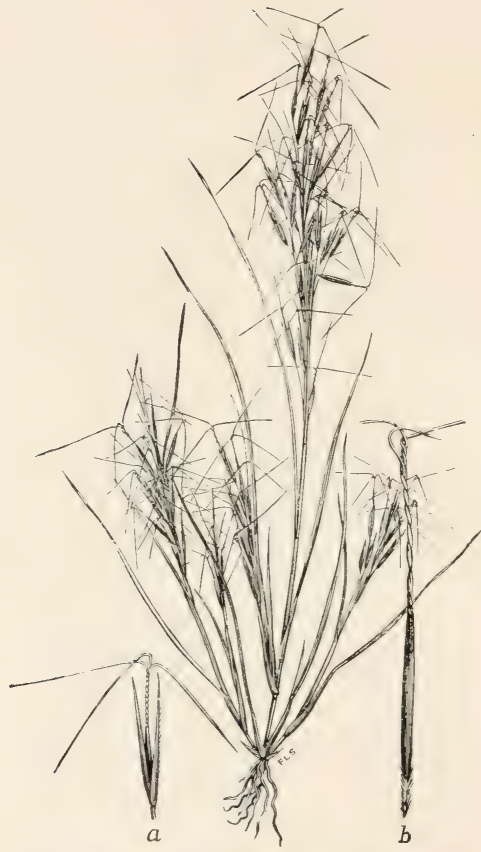

Firi. 88. Aristida tuberculosa Nutt. LoN(i-AwNed PovertyGRAss. - A rigid, much-l,ranched perenuial 3 to 4.5 dm. high, with nearly simple panicles 10 to $18 \mathrm{~cm}$. loug. The widely spreading, nearly equal awns 3 to $4 \mathrm{~cm}$. long.-Dry, sandy soil, near the coast, Massachusetts to Mississippi ; also in Illinois, Wisconsin. and Minnesota. Angust-Oetober. 


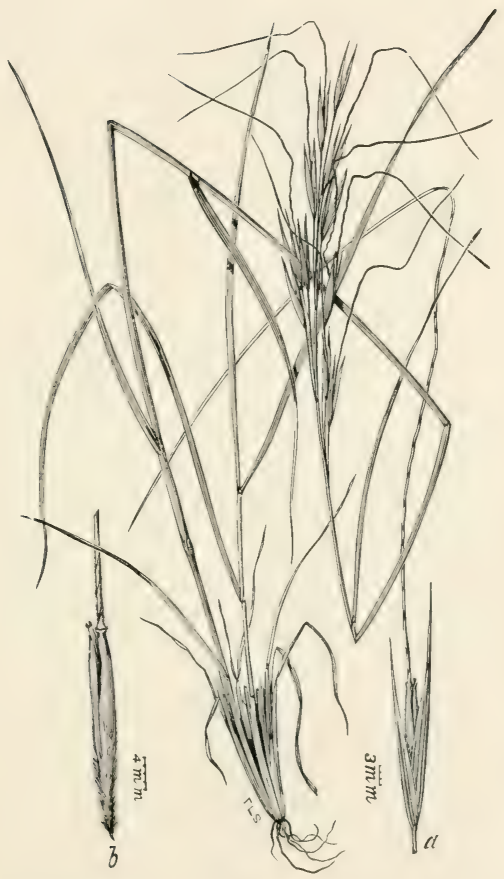

Fig. 89. Stipa spartea Trin. Porcunine-grass.-A stout, erect perennial, with simple eulms 6 to $10 \mathrm{dm}$. high, long, narrow leaven and few-flowered panicles. The strong, twisted awns are 8 to 15 $\mathrm{cm}$. long, and at the hase of the flowering glume is a lomg. pointed, and hearded callus.-Prairies, Illinois to Colorado, north to Manitoba and British Columbia. June-Angust. 


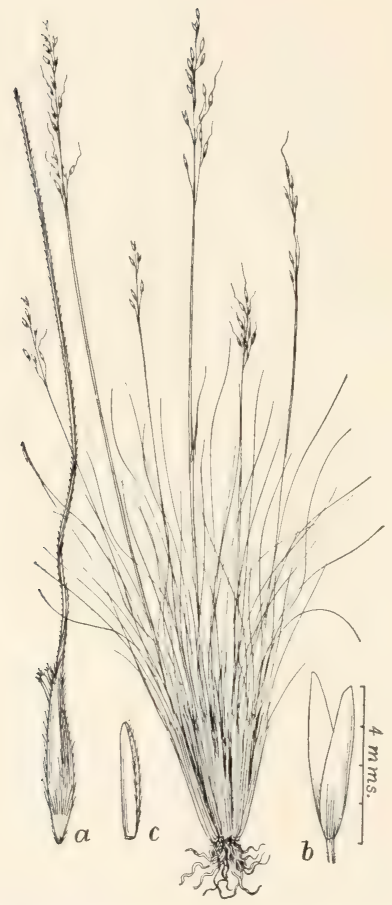

FIG. 90. Stipa kingii Boland. (Oryzopsis kingii Beal, Grasses N. Am., 2: 229). - A slender, erect, cespitose perenuial 2 to $4 \mathrm{dm}$. high, with involute, filiform leaves and contracted panicles 8 to $12 \mathrm{~cm}$. long. Awns seabrous.-California and (?) Nevada. 


\section{9}

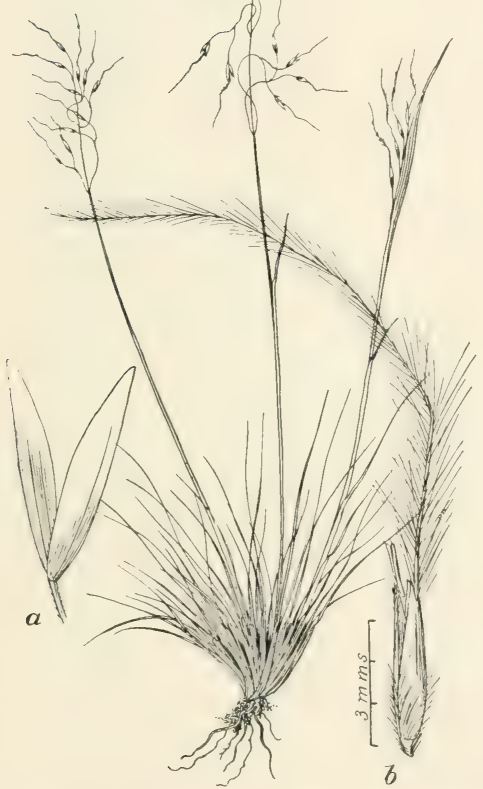

FIr. 91. Stipa mongolica Trin.; Beal, (irasses X. Am.. $2: 2 \cdot 27$ (sul, ()ryzopsis). - I slender, deusely tufted perennial about :3 ilm. high, with short, setaceous leaves and loosely few-flowered panirles. A wus plumose.-Mountains of colorarto. [Eastern Asia.] 


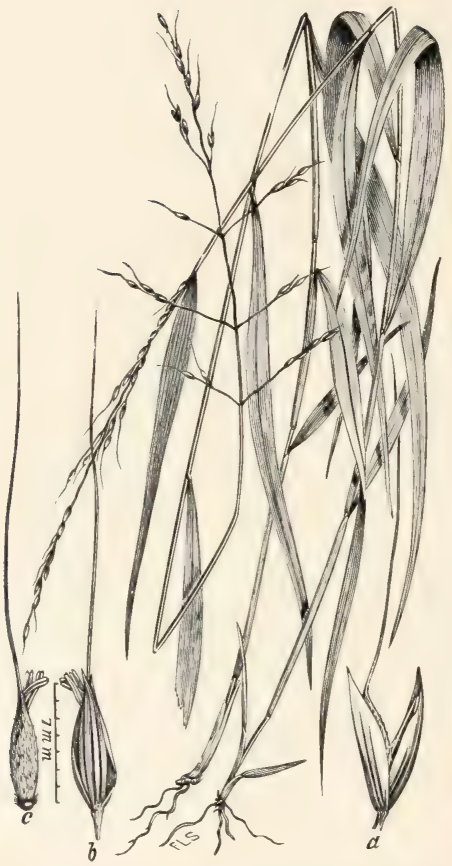

Fig. 42. Oryzopsis melanocarpa Muhl. Bıаск Mountaix RICE. - A rather stont, long-and hroad-leafed perennial 3 to $9 \mathrm{dm}$. high, with narrow, simple janicles of a few, large spikelets.-Opeu rucky woods, sometimes on rlifis, Quebec and Ontario to Delaware, Kentucky, Missouri, and Minnesota. July-ieptember. 


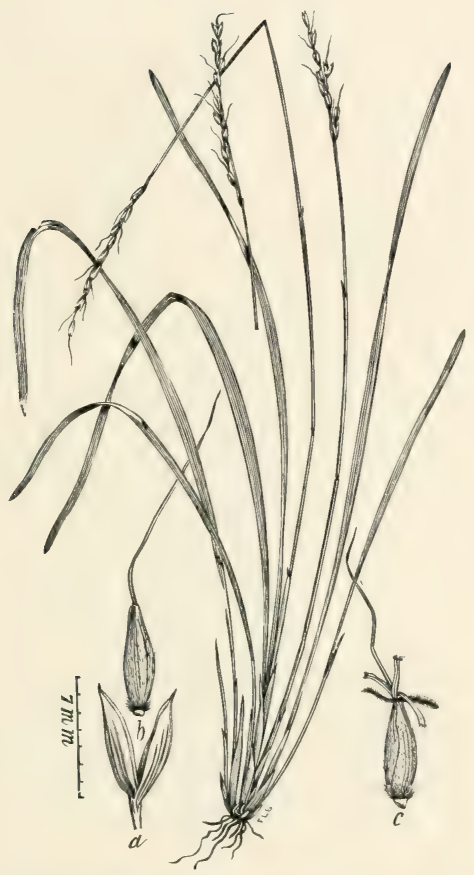

Fiti, 93. Oryzopsis asperifolia Michx. Wirte Moc'st.ix Ric'w.-A slender perennial 1.5 to is dm. high, with narrow, simple. panicles 6 to $10 \mathrm{~cm}$. long. The hasal leaves, which are 5 to $7 \mathrm{~mm}$. wirle, often overtop the culm.-Wools, New foundlaud, Massachu_ setts and New Jersey, to Mindesota and liritish ('olumbia, and sonthward in the lockies to New Mexico. Aprii-.July. 


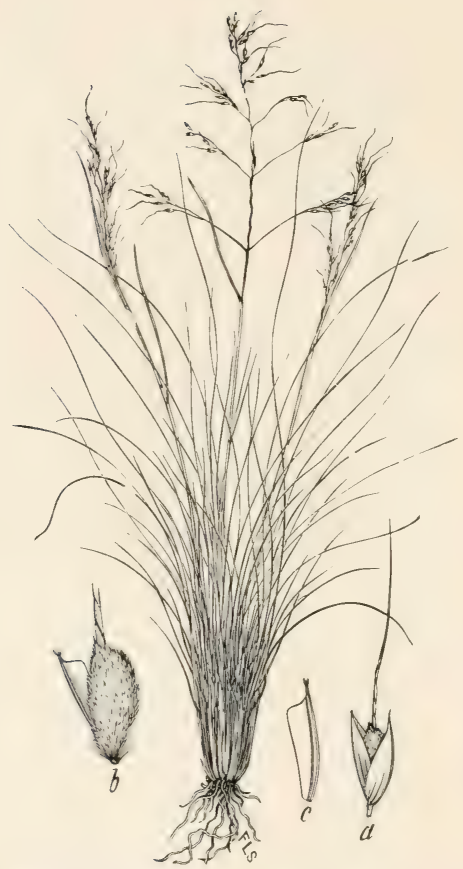

Fif. 94. Oryzopsis fimbriata (HIK.) Hemsl.; Beal, (irasses X. Am., 2 : 231.-A slemer, tufted perennial 5 to $x$ dm. high, with very narrow, involute leaves and loosely tlowered panicles 10 to $13 \mathrm{~cm}$. long.-In 'anyons and under limestone clifts, mountains of western Texis to California. [Mexico and Lower California.] July-September. 


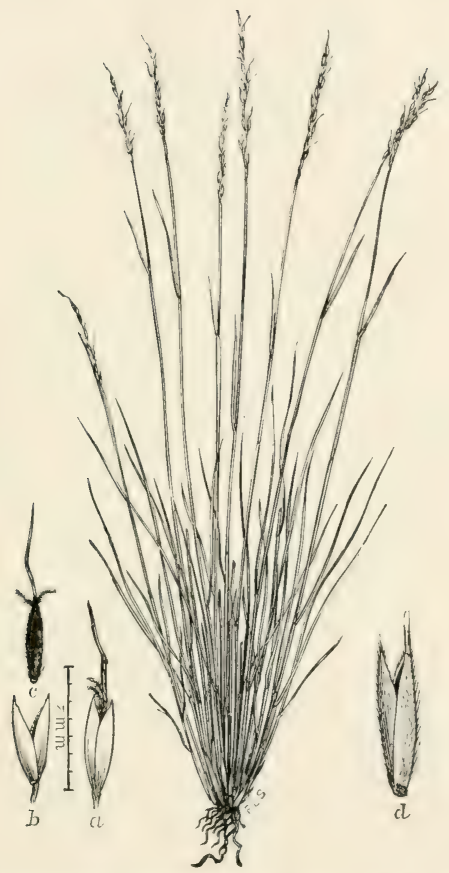

FIG. 95. Oryzopsis exigua Thurb.; Heil, (iranses N. Am., 2: 227. Litrin Morvtain Rice.-A slender native prennial 1.5 to 3 dm. high, with tiliform leaves, and narrow, simple, few-flowered panicles 20 to $5 \mathrm{~cm}$. long. - Among rocks in canyons and on mountain tops, Montana and Wyoming to Vtah, Oregon, and Washington. June-August. 11162-No. 7 


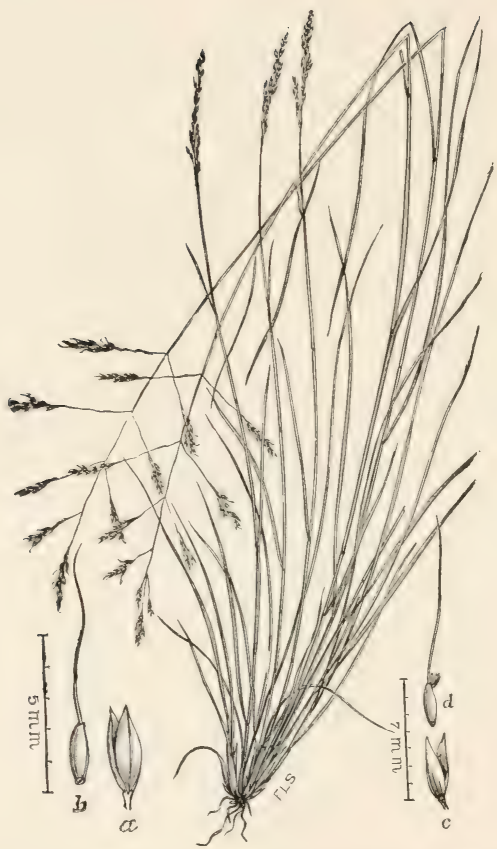

Fi(i, 96. Oryzopsis micrantha (Trin. \& Rupr.) Thurb. NMALL-

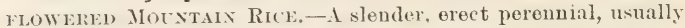
about $6 \mathrm{dm}$. high, with narrow leaves and small-flowered, open panicles $x$ to $16 \mathrm{~cm}$. lons.-Woods, river bluff's, and mountain sides, South Dakota to Nobraska, (olorado, New Mexico, and Arizona. Jume-August. 


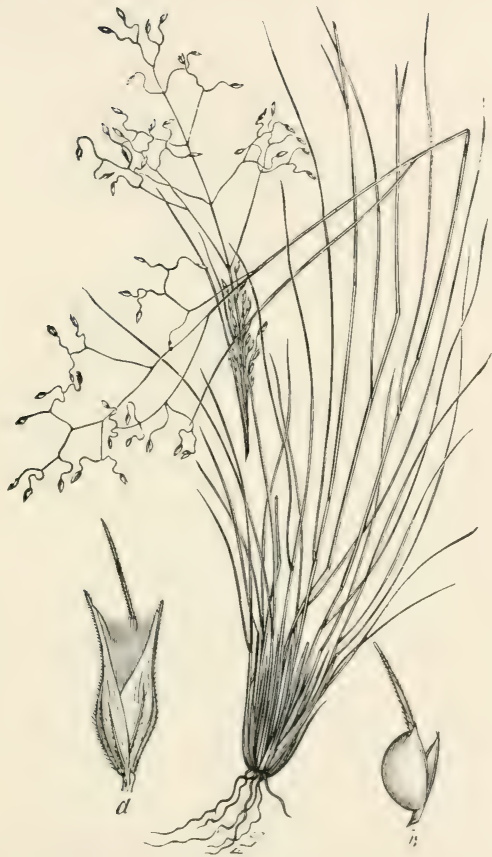

Fir: 97. Eriocoma cuspidata Nutt. (stipa membranacea P'ursh,

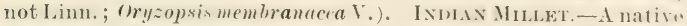
peremial, growing in bunches 3 to 7 dus. high, with narrow, incolute leaves and peculiarly branched, difiuse panieles 1:2 to 15 em. long.-firassy slopes, dry hillsides, samdy river banks, about springs in deserts, in enltivated lields, ete., South D)aliota to New Mexien, California, and British Columbia. [Mexien.] May-september. 


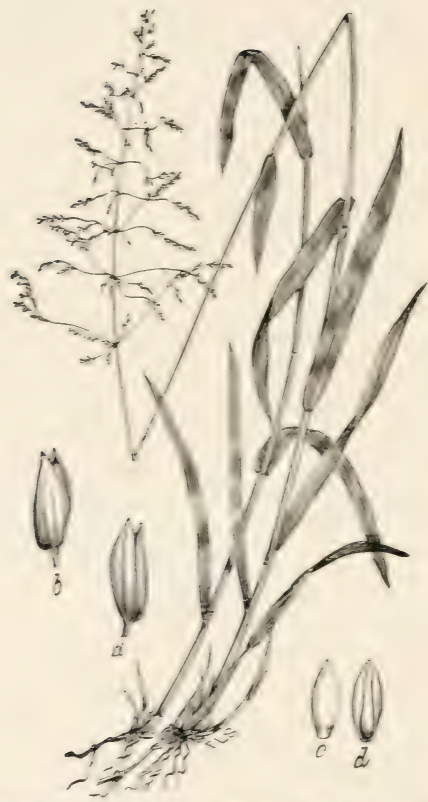

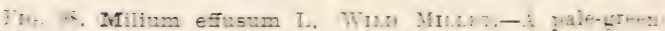

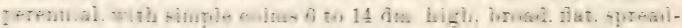

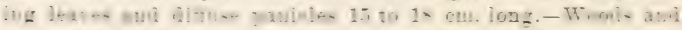

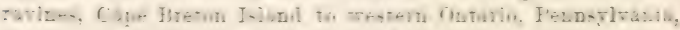
Michigan, aud Minnesota. [Enrope. Asia.] June, Juls. 


\section{(1)}

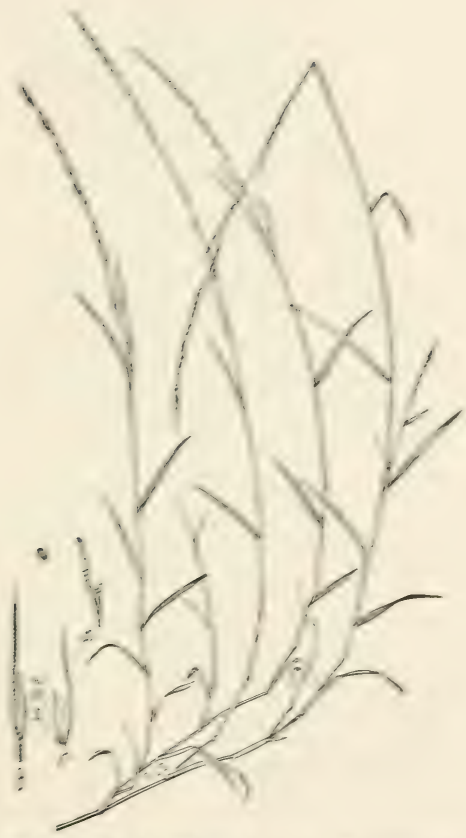

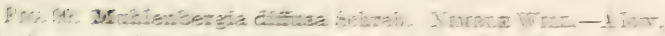

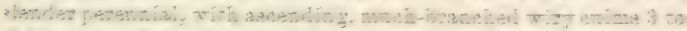

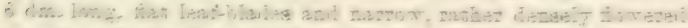

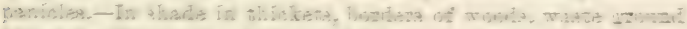

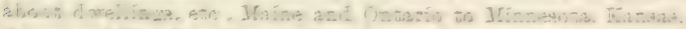

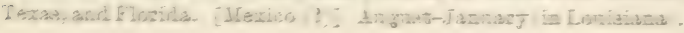




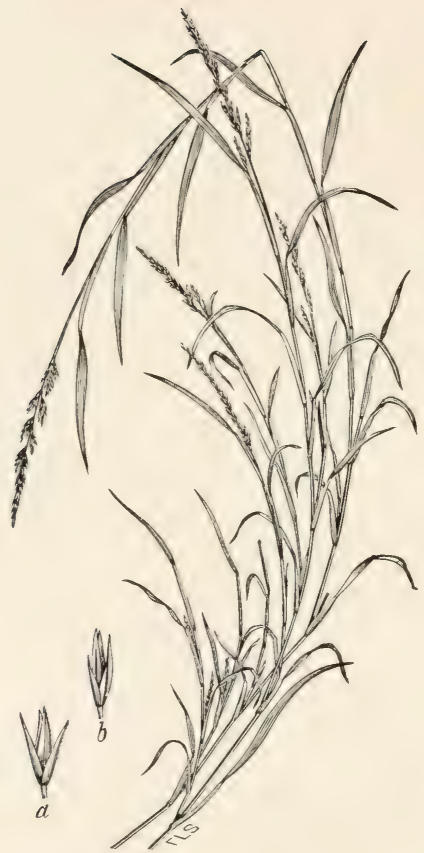

Fig. 100. Muhlenbergia mexicana (L.) Trin. Mexicax DropSEED,-An upright or ascending, usually much-hranched perennial 3 to 9 (lu. high, with a sealy, ereeping rootstock, numerous, flat leaf blades and contracted, densely flowered panicles._Sandy or rocky banks of streams aud low thickets, New Brunswick and Ontario to North Carolina, Iudian Territory, and South Dakota. 


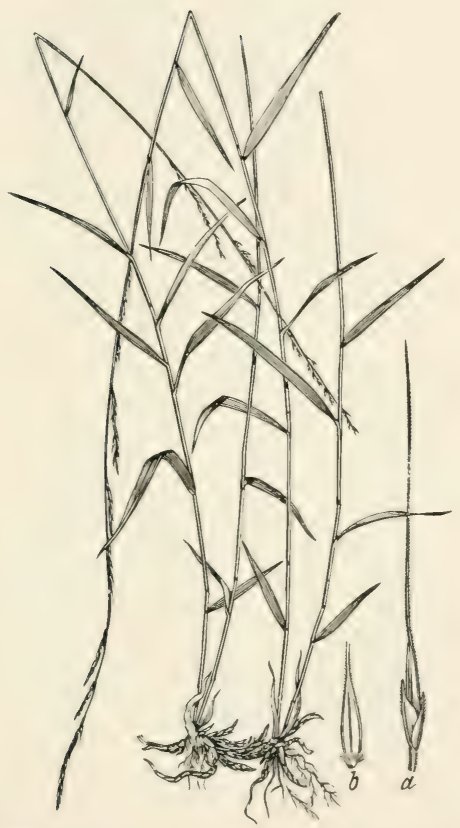

FIf. 101. Muhlenbergia tenuiflora (Willd.) 13. S. P. (M. willd-

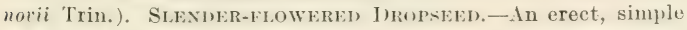
or sparingly branched peremnial 3 to $9 \mathrm{dm}$. high, with creeping, scaly rootstocks, hat leaf blales and rather few-llowered, linear panicles.-Rocky woods, Massachusetts to ()ntario, Minnesota, Texas, Alabama, and Virginia. August, September. 


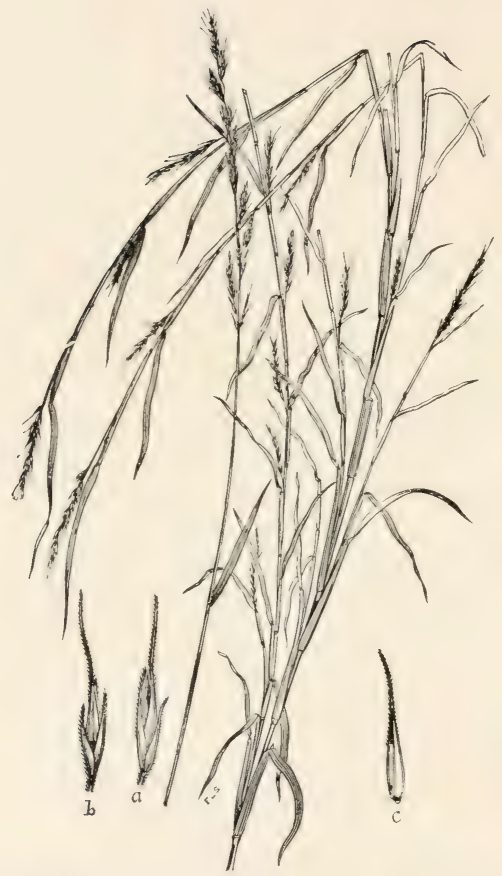

Fit. 102. Muhlenbergia sylvatica Torr. Wo(n)l.ANI) DropSEED.-A perennial, usually much-branched grass 6 to $9 \mathrm{dm}$. high, with strong, scaly rootstocks, llat leaves and narrow, densely flowered panicles 5 to $15 \mathrm{~cm}$. long.-In rocky woods, and wooded banks of streams, New lirunswick and Ontario to North Carolina, Tenuessee, 'Texas, Kansas, aud Minnesota. August-Uctober. 


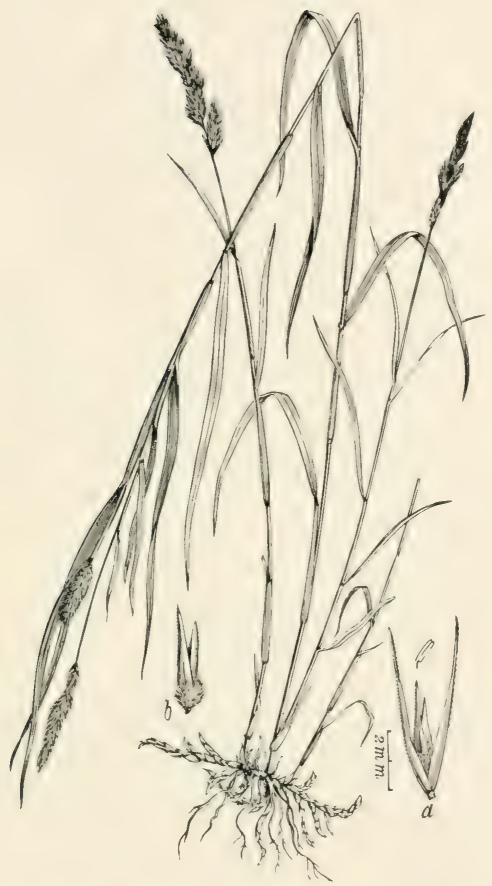

FI(i, 10:3. Muhlenbergia racemosa (Michx.) I. S. P. ; Britton

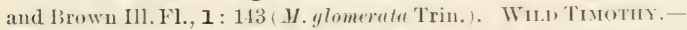
A rither stont, upright perennial, with very tough and densely scaly rootstocks, nearly simple culms 6 to 9 dm. high, and densely flowered, narrow panicles 5 to $10 \mathrm{~cm}$. long.-Moist mearlows and low gromuls, Newfound and to New Jersey, Missonri, Arizona. and British Columbia. June-September. 


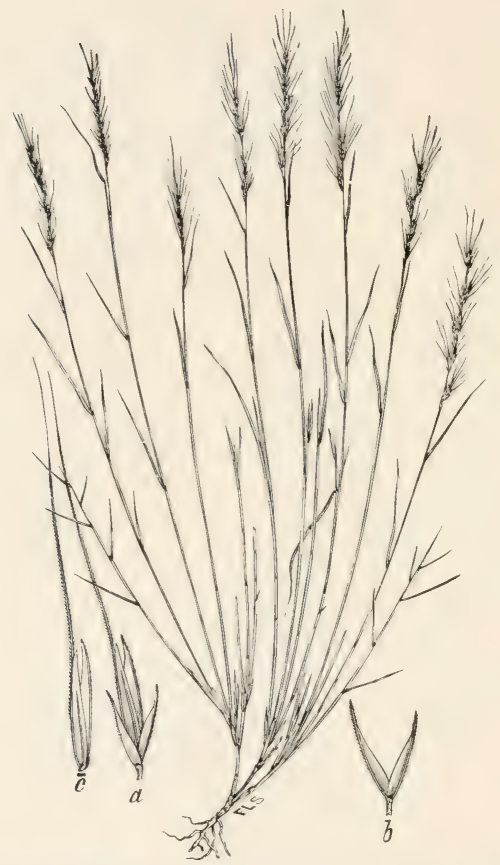

FIG. 104. Muhlenbergia pringlei Seribn.; Beal, Grasses N. Am., 2 : 257.-An erect, densely ciespitose, wiry perennial, with simple enlms 3 to $4 \mathrm{dm}$. high, involute-filiform leaves and slender, contracted, often purplish panicles 6 to $10 \mathrm{~cm}$. long.-Canyons, basius, and shaded ledges, mountains of New Mexico and Arizona. [Mexico.] May-September. 


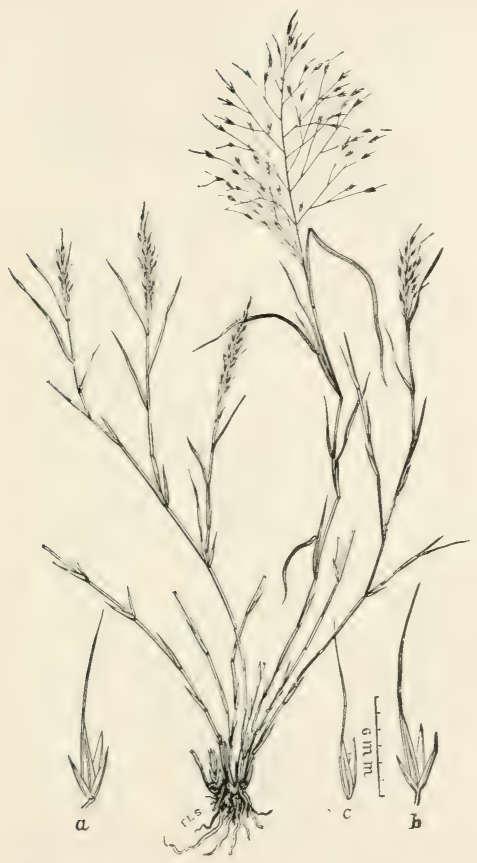

Fic. 105. Muhlenbergia porteri Scribn. in Beal, firasses N. Am., 2 : 259 (. . texana Thurb. not Buckley), -A much-branched native perennial, with slender, somewhat wiry stems 3 to $6 \mathrm{dm}$. long, rather short, narrow leaves, and difhuse panicles. Valuable for grazing and for hay.-Dry mesas and table-lands, Texas to Arizona, Nevada, and California. [Mexico.] Angust, Neptember. 


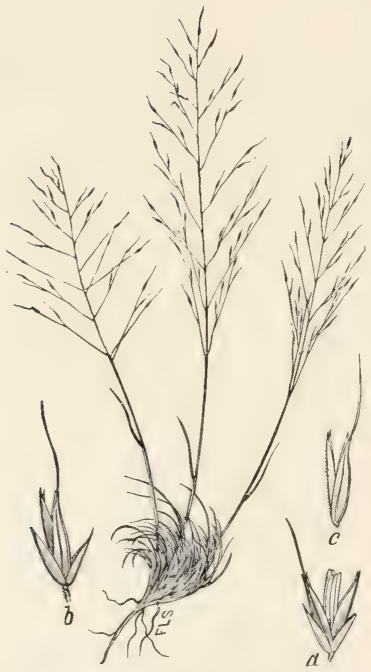

FIG. 106. Muhlenbergia gracillima Torr. ; Beal, Grasses N. Am., 2: 261.-A densely tufted pereunial, with slender culms 2 to $4 \mathrm{dm}$. high, numerous involute basal leaves and open capillary panicles 10 to $15 \mathrm{~cm}$. long.-Dry plains, Kansas to Colorado, Texas, and Arizona. July-October. 


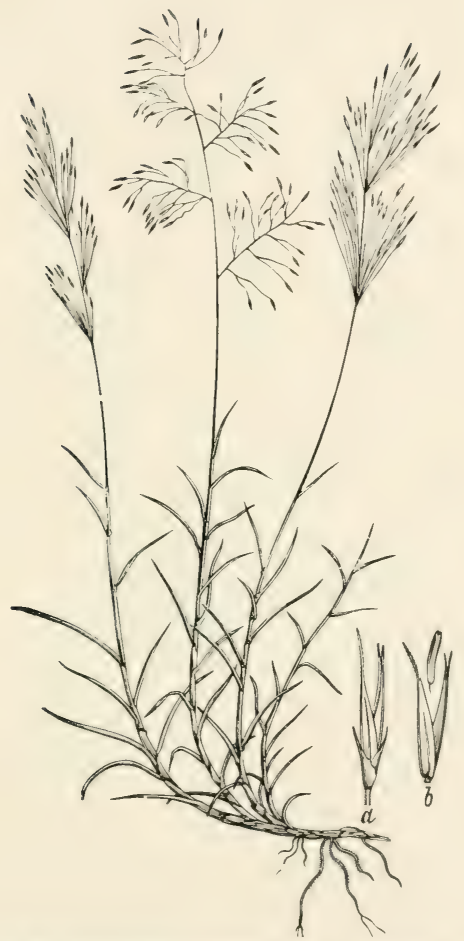

FIG. 107. Muhlenbergia pungens Thurb.; Britton and Brown, Ill. Fl., 1: 146. - A rigid, native perennial 3 to 4.5 dm. high, with firm, sharp-pointed leaves and open panicles aloont $15 \mathrm{~cm}$. long.-I)ry soil, sand hills and plains, Nebraska to Utah, Texas and Arizona. July-October. 


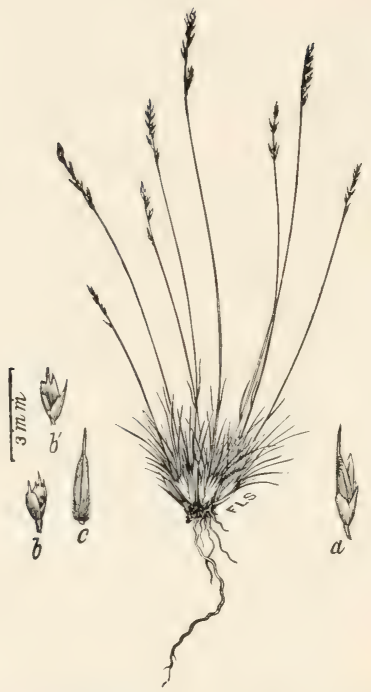

Fis. 108. Muhlenbergia filiculmis Vasey; Contrih. T. S. Nat. Herb. 1 : 267 ; Beal, Grasses N. Am., 2 : 250. THrea1-Like MuHLexBFrGiA.-A low, tufted pereunial with tiliform scape-like eulms 1.5 to $3.5 \mathrm{dm}$. high, setaceous ratical leaves and narrow, spike-like panicles 2 to $5 \mathrm{~cm}$. long.-Sanily soil, Ute Pass, El Paso County, in moist prairies at c'omo, Park County, aud on the mesas at 'Twin Lakes, Lake County, Colorado; alt. 2,000 to $3,000 \mathrm{~m}$. July-September. 


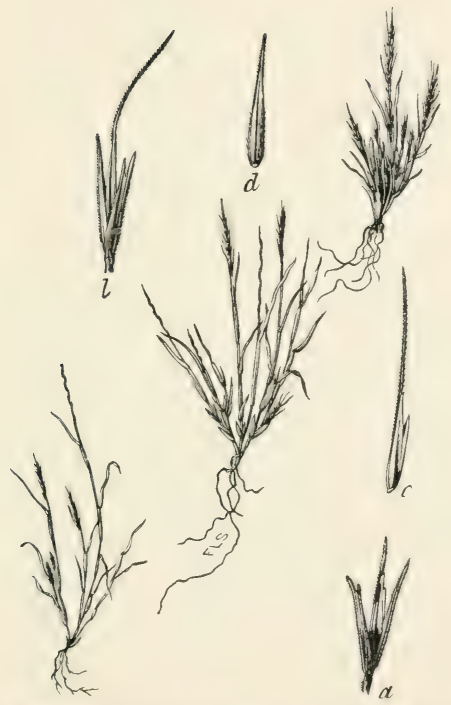

FI(x. 109. Muhlenbergia schaffneri Fouru; Beal, Grasses N. Am., 2 : 239.-A low, earpitose, branching anumal 2 to $10 \mathrm{~cm}$. high, with short leaves and simple, spike-like panicles. Awn of the flowering glume 1 to 7 lines long.- "Dry, gravelly patches of thin soil," mountains of Arizona and New Mexiro. [Mexico.] September. 


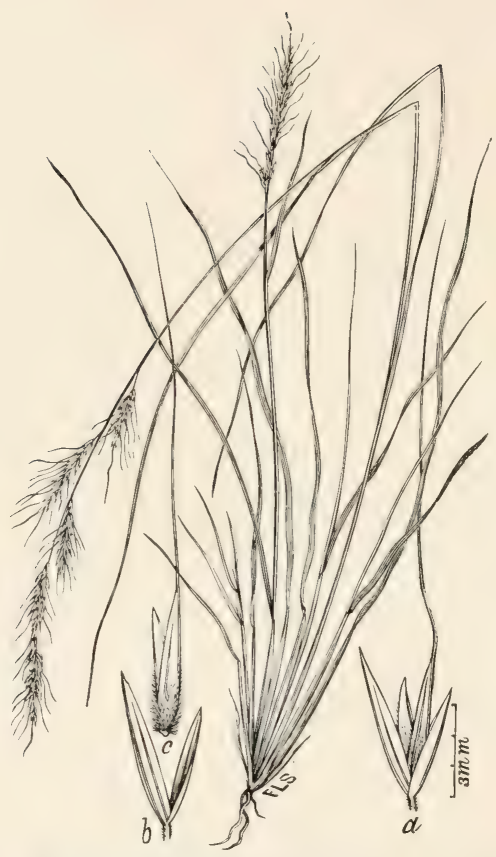

FIG. 110. Muhlenbergia virescens (HBK.) Trin.; Beal, Grasses N. Am., 2 : 242. - A rather slender, erect perennial about 6 du. high, with long, narrow leaves and a strict, pale-green or strawcolored panicle abont $15 \mathrm{~cm}$. long.-At an altitude of 1,800 to $2,400 \mathrm{~m}$. on the mountains of Arizona and New Mexico. [Mexico.] May, June. 


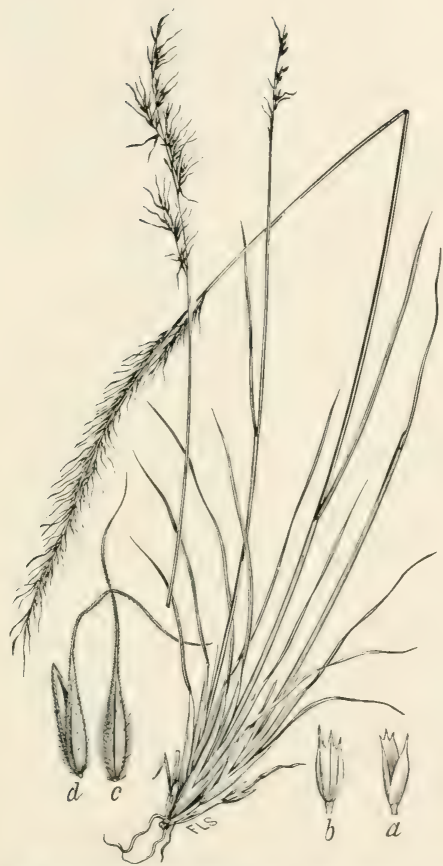

Fit. 111. Muhlenbergia gracilis Trin.; lieal, Granses N. Am., 2: 212.-A slender, but rather aigid, densely aspoitose perennial 1.) to 6 dm. high, with narrow, involute leaves, and rontracted paricles $x$ to $15 \mathrm{~cm}$. long.-Ascending to 2.700 m. or more Texas to Arizona, Colorado, and Wyoming. [Mexico.] .June-September. $11162-$ No. $7-9$ 


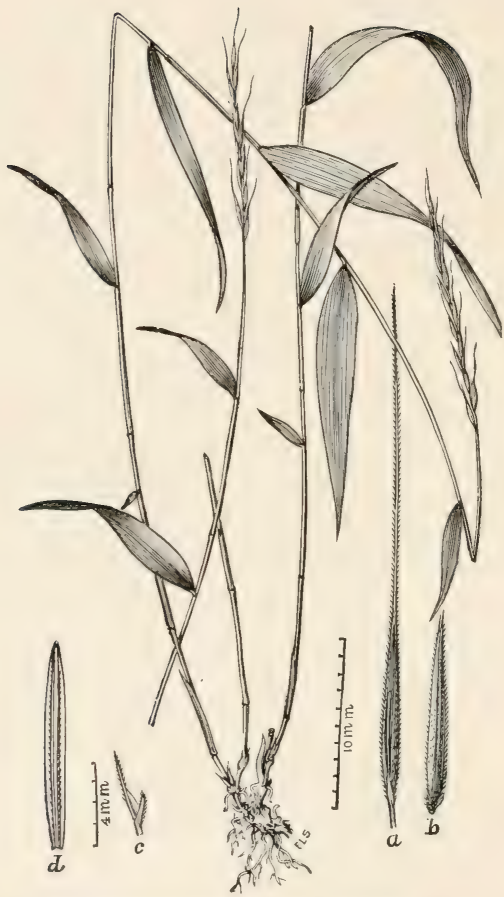

Fig. 112. Brachyelytrum erectum (Schreb.) Beauv. (B. aristatum R.\& S.). BEnRden, Short-HUsk.-A peremnial, with simple eulms 3 to $9 \mathrm{dm}$. high, that, spreading leaf blades and fow-flowered. simple, terminal panicles.-Open, rocky wooks, Newfoundland to North Carolina, Alabama, Missouri, and Minnesota and Ontario. May-August. 


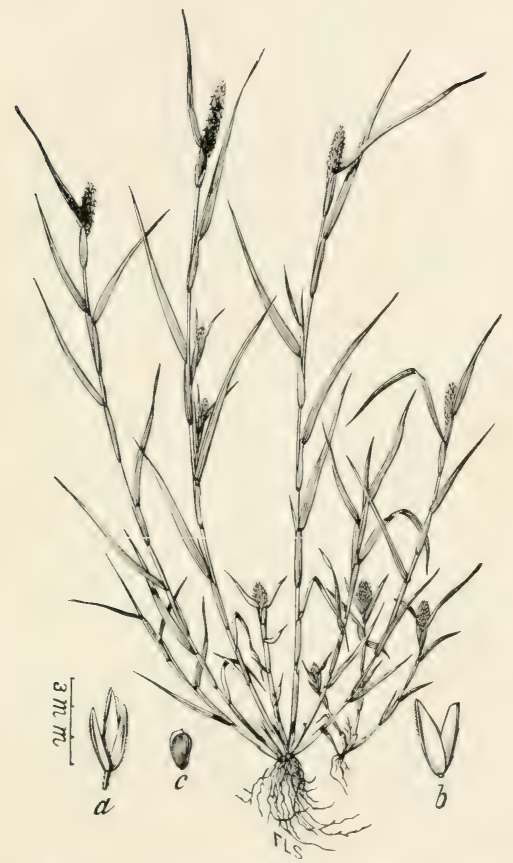

Fic. 113. Heleochloa schœnoides (L.) Host (I'hleum scharnoides L.; Crypsis schanoides Lam.). Rusi-Like Tпмоти.-A difusely hranching cerspitose ammal 1 to $3 \mathrm{dm}$. high, with inflated sheaths, rather short, spreading leaves, and densely flowered ovate, or oblong, spike-like panicles. - Waste groumd abont New York City, P'hiladelphia, ete, sparingly naturalized. [Europe and Asia.] July, August. 


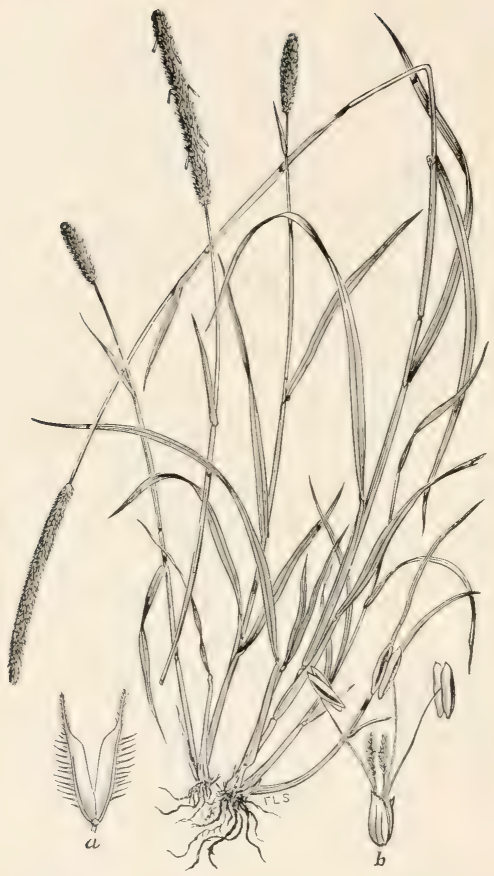

Fig, 114. Phleum pratense $I_{d}$. Tmotny. - A peremial with erect, simple culms 3 to $12 \mathrm{dm}$. high and dense, cylindrical, spikelike panicles $2.5 \mathrm{to} 10 \mathrm{~cm}$. long. - Widely cultivated and completely naturalized in fields, wassides, and waste ground throughout the Inited States and British America. [Europe and Asia.] JuneAugust. 


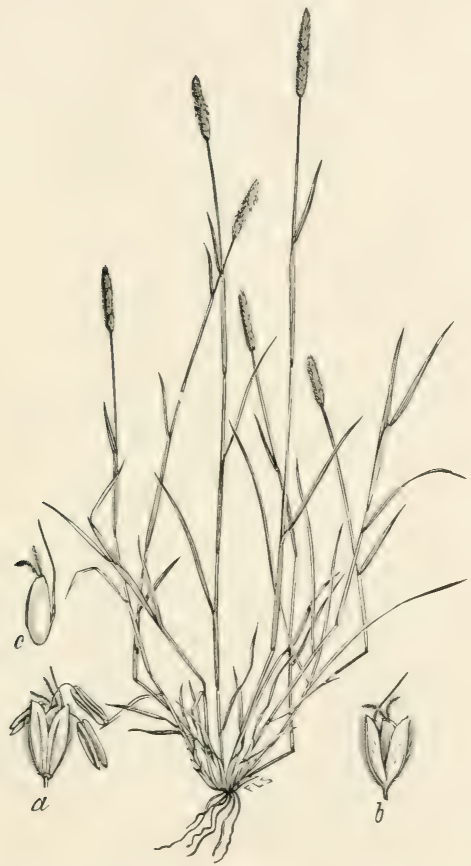

Firi. 115. Alopecurus geniculatus L. Fiontini; Foxtir..-A slember perennial, with culms decumbent and branched at base, then erect or asmending, 1.5 to $6 \mathrm{~d}$ dm. high, th: t, spreading leaves and dense, spike-like, slender panicles 2.5 to 7.5 ('m. long.-Wet meadows, banks of streams and ditrhes throughout the I nited States, and from Newfoundland to British Columbia. [Enrope and Asia.] April-September. 


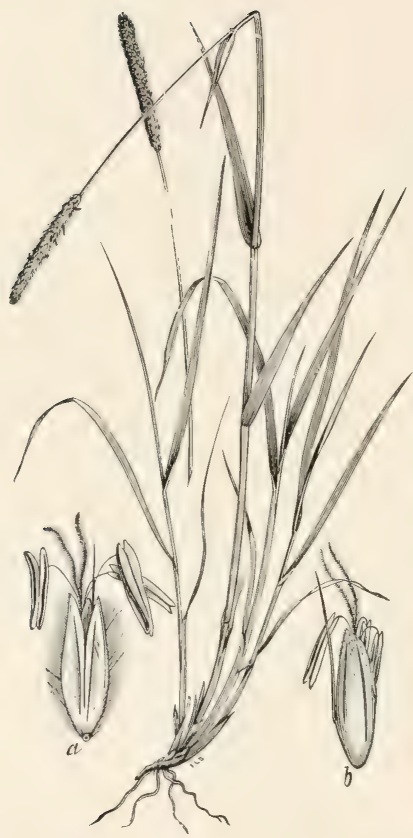

Fig. 116. Alopecurus pratensis L. Meanow Foxtail. -An erect, smooth perennial 3 to $9 \mathrm{dm}$. high, with short, creeping rootstocks, tlat, spreading leaf blades, aud deuse, cylindrical, spikelike panicles 5 to $10 \mathrm{~cm}$. long.-Naturalized in fields and meadows, Labrador to sonthern New York, Ohio and Michigan; also Oregon, Idaho, and California. [Europe, Asia, and Africa.] June, July. 


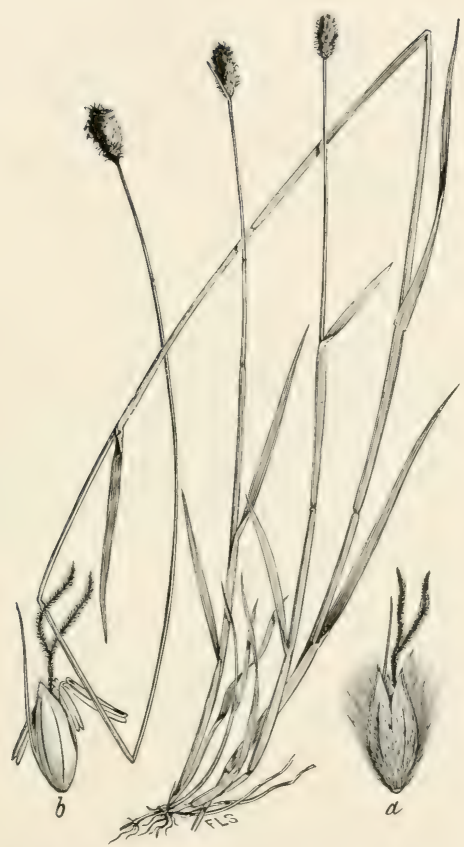

FIt. 117. Alopecurus occidentalis Scrihn. (A. pratensis ulpestris A. (iray). Modxtax Foxtul.-An erect, rather slender grass 6 to $9 \mathrm{dm}$. high, with shorter and thicker heads than those of Meadow Foxtail. - Wetmeadows and banks of streams, high mountains of Montana, Idaho, Wyoming, and Colorado. June-September. A valuable hay grass. 


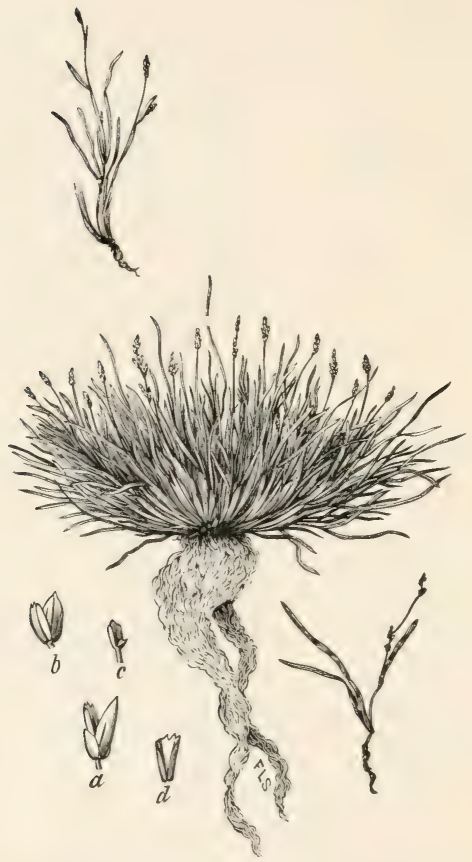

FIr. 118. Phippsia algida (soland.) R. Br.; Britton and Brown, Ill. ll., 1: 150. I'Hursia.-1 low, tufted, glabrous perennial 2 to $10 \mathrm{~cm}$. high, with narrow, soft, and flat leaves and contracted, simple panicles. - Aretic North America and on the highest monntain peaks of c'olorado. [Greenland, arctic Europe, and Asia.] July, August. 


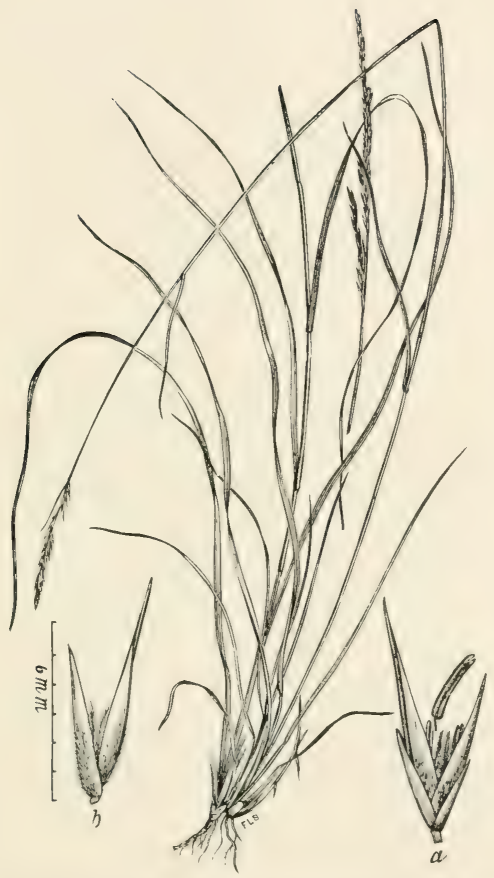

Fivi. 11!). Sporobolus asper (Michx.) Kunth 1.Ifrostis asper Miehx.). Pranniz-(irass.-A rather slender peremnial 3 to 9 dm. high, with usually long, involute-tiliform leaf blates and contracted, linear panicles 5, to 15 cm. long.-In dry. sandy soil. open wools and grades, Long Island to Floricla, west to Texas, Missonri, and Illinois. Angust-fetober. Aroided by stock excepting when young. 


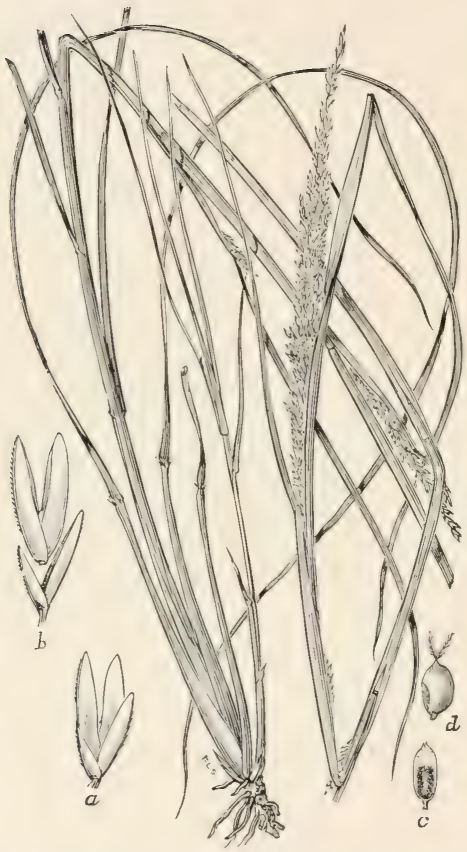

Fitr. 120. Sporobolus longifolius (Torr.) Wood; Britton and Brown, Ill. Fl., 1: 151. LoNi-LEAFEv sporoBoLes,-A stout perenuial 3.5 to $10 \mathrm{dm}$. high, with very long, atteunate-pointed leaves, and strict, spike-like panicles 3 to 10 inches long, which are more or less included in the intlated leaf sheaths.-Dry, sandy soil. Maine to Penusplvania, Nouth Dakota and Utah, south to Texas and Florida. August-October. 


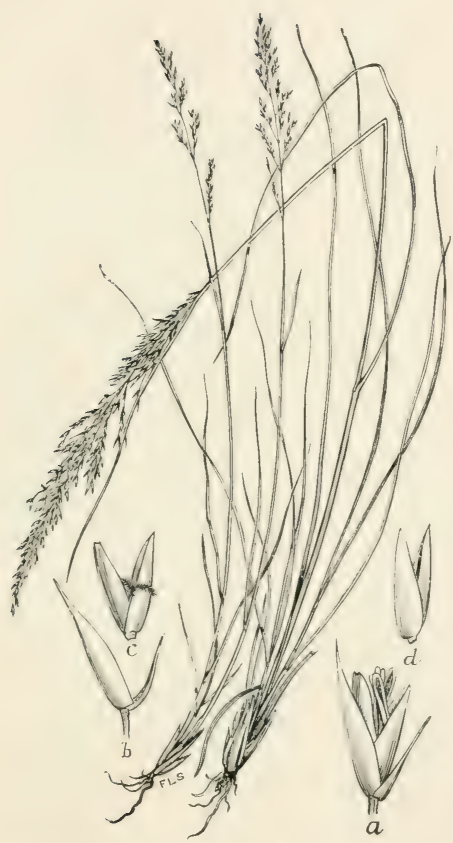

Fig. 121. Sporobolus heterolepis A. (iray. STRONG-ACENTED Sponomolus.-A rather stout, somewhat wiry, easpitose perennial 6 to $9 \mathrm{dm}$. high, with very long hasal leaves and loose, opren panicles.-In dry soil, prairies, etc., Connecticut to Queber, Iowa and Vol,raska aud Wroming, thenee south to Texas and north to Assiniboia and Naskatchewan. Angust, september. 


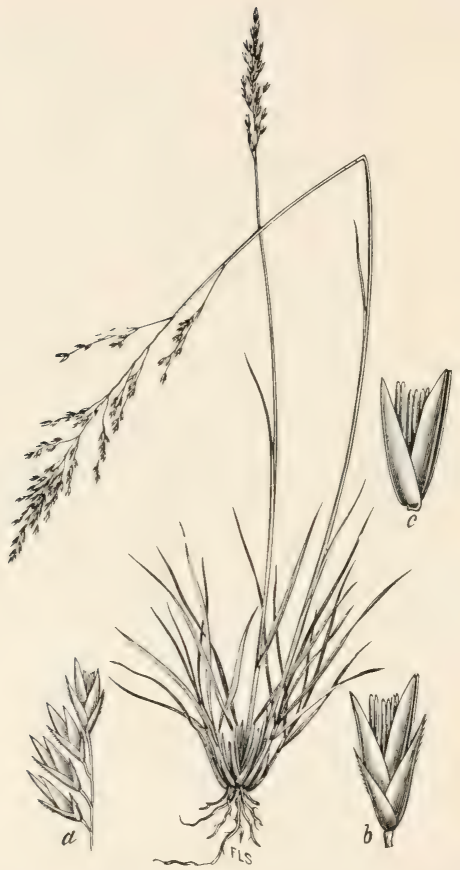

Fici, 122. Sporobolus interruptus Vasey; Beal, Grasses $\mathrm{N}$. Am., 2 : $2 \times 6 .-1$ rather stout, erect peremuial with simple culm. ahout $4 \mathrm{dm}$. high, flat leaves and narrow but loosely flowered panicles 10 to $18 \mathrm{~cm}$. long.-In forests, mountains of Arizona. August, September. 


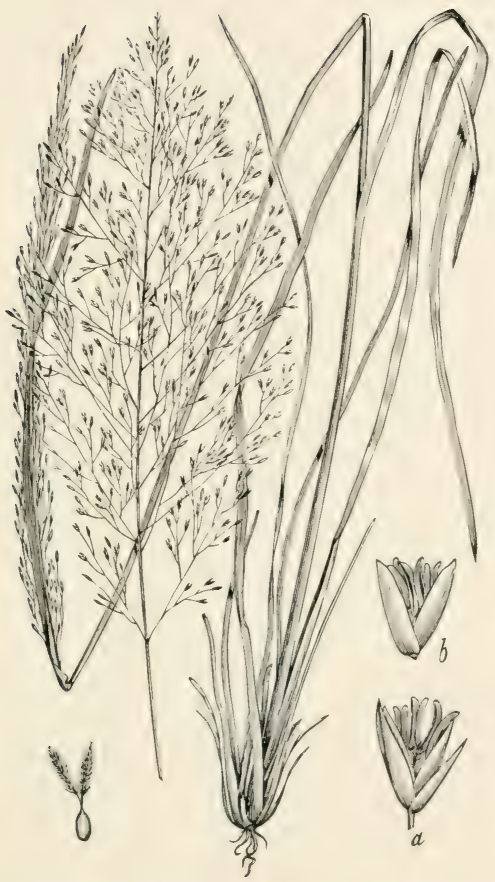

Fri. 12:3. Sporobolus floridanus Chapm.-1 rather stout, ereet perennial if to 12 dut. high, with long, narrow leaves and diffuse panieles2.5 to $5 \mathrm{~cm}$. long. Peelicels eapillary; spikelets purplish.Ioist pine harrens near the roast. North ('arolina to western Florida. July-September. 


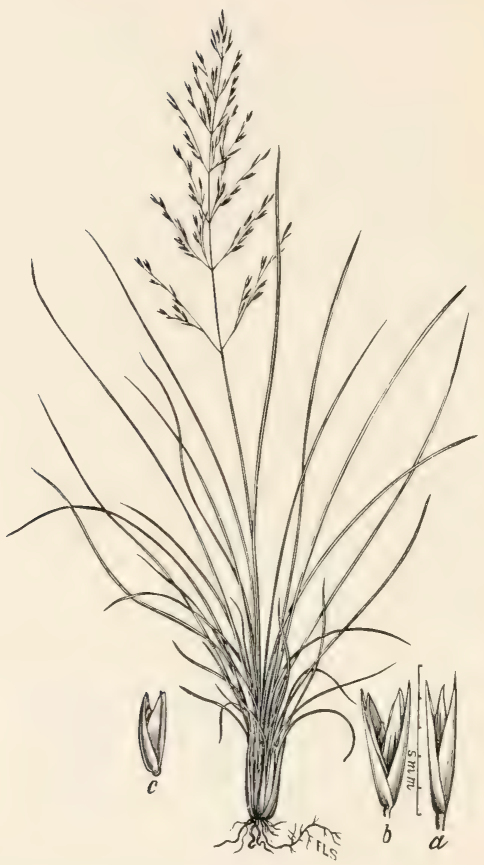

FIG. 124. Sporobolus curtissii (Vasey) Small. (S. floridanus curtissii Vasey; Beal, Grasses N. Am., 2 : 290).-A wiry, erect perennial 3 to $6 \mathrm{dm}$. high, with very long leaves and loosely flowered, open panicles 15 to $25 \mathrm{~cm}$. long.-Moist pine barrens, northeastern Florida. July-November. 


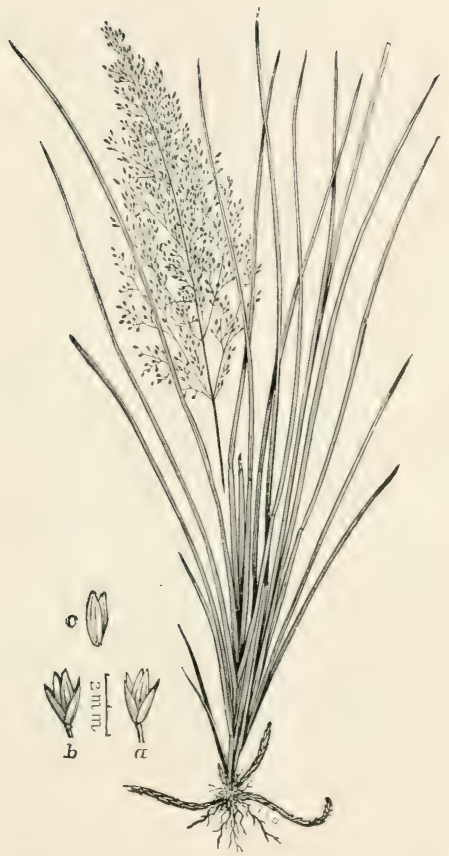

FIG. 125. Sporobolus compressus (Torr.) Kunth. (Agrostis com-

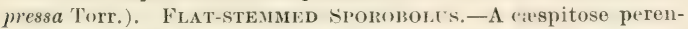
nial, with short, scaly rootstocks, flattened eulms 3 to $6 \mathrm{dm}$. high, rather long, cominplicate leaves and open, eapillary panicles 10 to $30 \mathrm{~cm}$. long.-In bogs and pine harrens, Long Island and Now Jersey. September, October. 


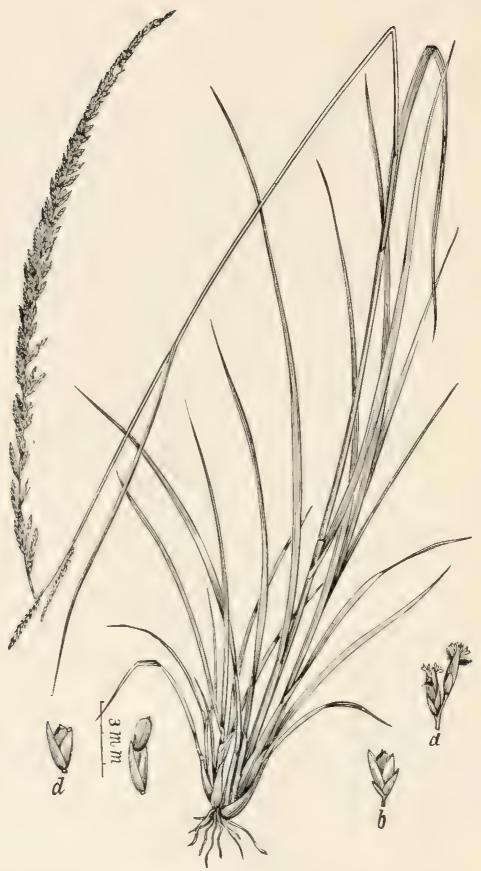

Fici. 126. Sporobolus indicus (L.) R. Br. Niuti-tinass.-A tufted, wiry, erect perennial 3 to $9 \mathrm{dm}$. high, with simple culms and narrow, densely tlowered, spike-like panicles 10 to $30 \mathrm{~cm}$. long.-A Abudantly naturalized in waste ground, waysides, fields, and pastures. Virginia and Tennessee to Florida, Arkansas, Texas, and California; occasional in the Eastern cities. [Native or naturalized in all tropical comntries.] Mareh-September. 


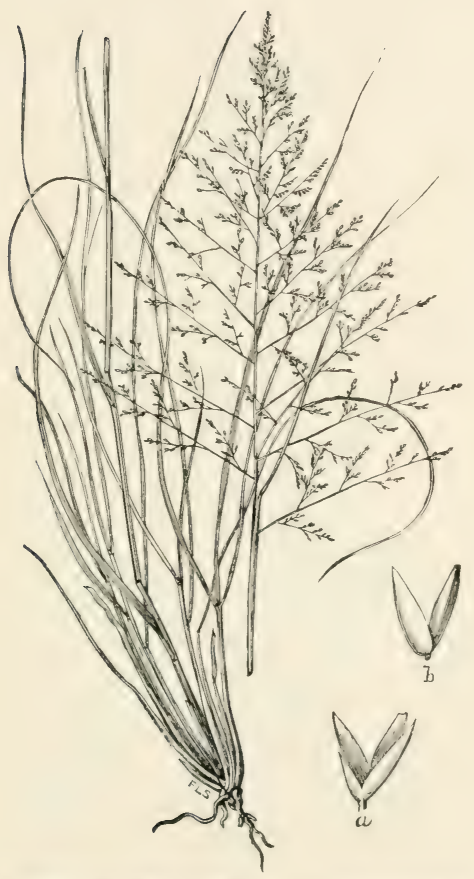

FIti. 127. Sporobolus airoides Torr. FINE-TOP AILT-riRASS.A stout, coarse, and rigirl perennial 3 to $9 \mathrm{dm}$. high, with long, narrow leaves and open, spreading panicles of many small spikelets.Moist or dry, usually saline or alkaline soil in deserts, proiries, along streams, in mealows, ete., Nebraska and Kiansas to Idaho, California, Texas, and Arizona. [Mexico and Lowor California.] July-September.

11162-No. $7-10$ 


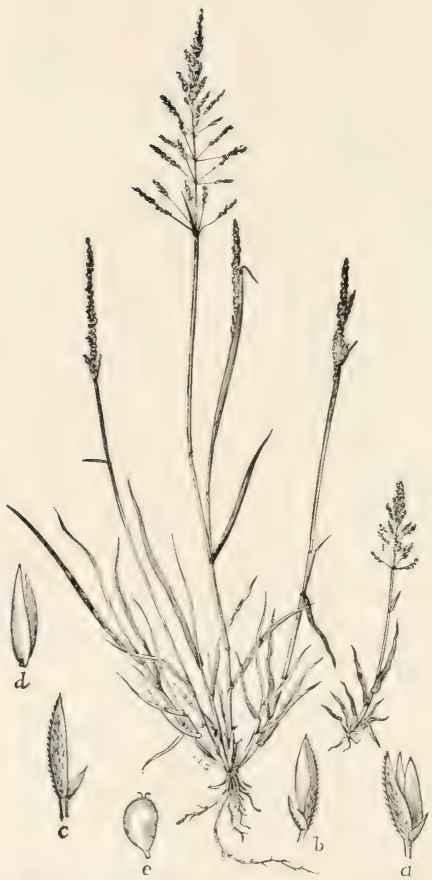

FIG. 128. Sporobolus argutus (Nees) Kunth (Filfa arguta Nees.); Beal, Grasses N. Am., 2 : 301.-A cirspitose perenuial 2 to $4 \mathrm{dm}$. hish, with flat leaves and open (at first strict) panicles 3 to $5 \mathrm{~cm}$. long.- "Sand dunes and sandy flats near river banks," Kausas and Coloradlo to Texas and restern Louisiana, also in southern Florida. [Mexico and West Indies.] May-September. 


\section{7}

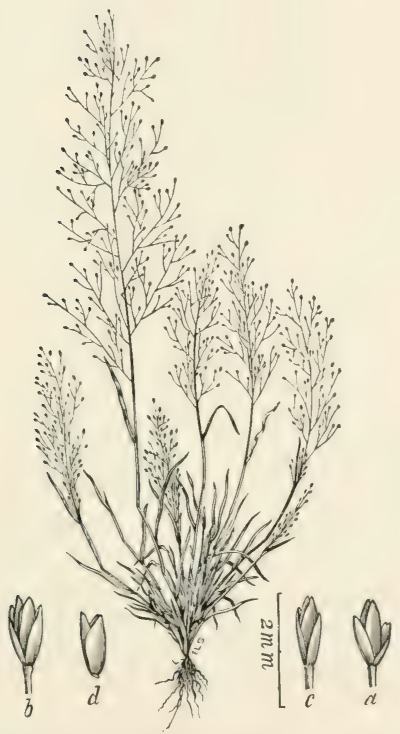

Fir. 124. Sporobolus confusus (Fon11.) Viasey; Beal, Grasses X. Am., 2 : 23!.-A slender. bram hing, tufterl annual 0.8 to 2 dm. high, with loose sheaths, flat leaves, and aypillary, ovoid or oblong panirles $x$ to 15 em. long. - sandy banks of streams, moist plares in santy plains, canyous, ete., Texas to California, and in colorado aud Montana. [Mexico.] July-September. 


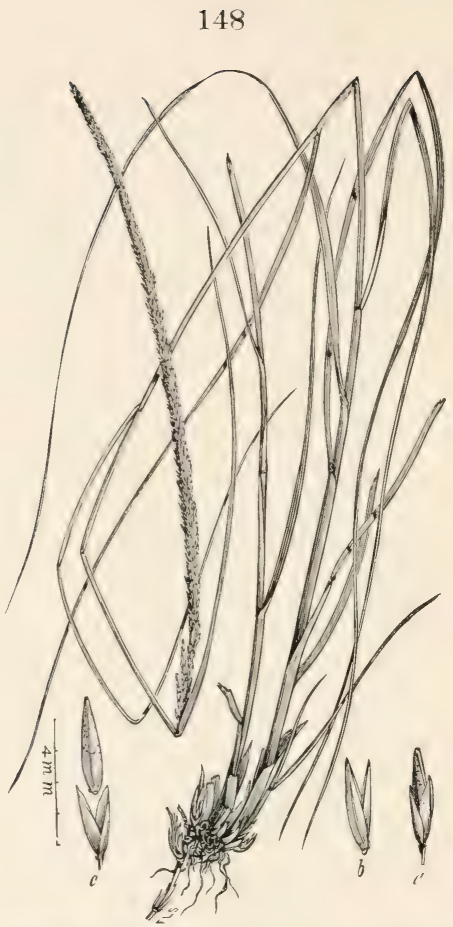

FIG. 130. Epicampesrigens(Boland.); Benth.; Beal, Grasses N. Am., 2: - (C'inna macroura Thurb. not Kunth; Tilfa rigen: Boland. not Trin.). DeEr-grass.-A stout, erect perennial, with rigid, wiry culms 9 to $12 \mathrm{dm}$. high; long, narrow leaves and very long, narrow, and densely flowered spike-like panieles. - In the foothills, Texas to Nevada, New Mexico, Arizona, and southern California. [Mexico.] July-November. A bunch-grass of some agricultural value. 


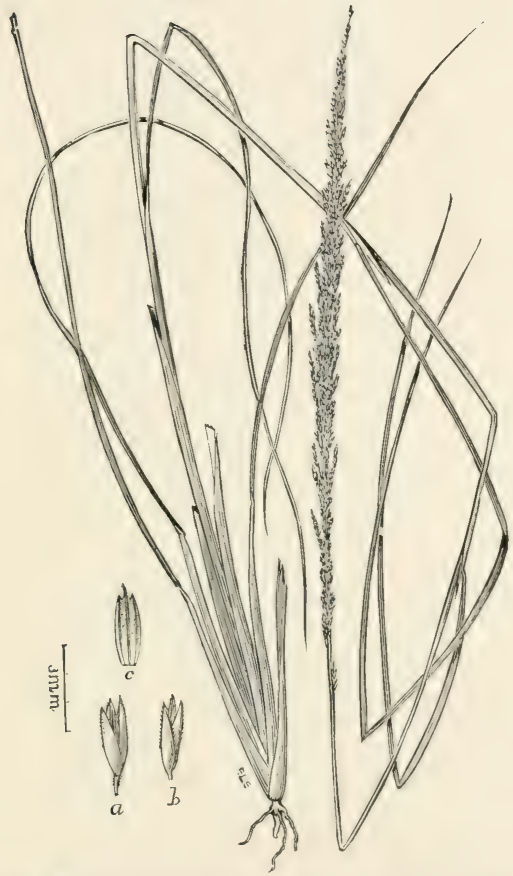

Fig, 131. Epicampes ligulata Stribn. 81, nor.-A stout, rigid perennial 6 to 12 du, high, with narrow, very scabrous leaves and strict, rather densely flowered panicles 20 to $40 \mathrm{~cm}$. long. Leaves long-attenuate pointed, rigitl, and subinvolute at the hase, where they are much narrower than the rigid ligule, which is 10 to $30 \mathrm{~mm}$. long. Spikelets dark purple, glumes suberpul.-('ool slopes and canyous, mountains of Now Mexico and Arizonit. [Mexico.] August, September. 


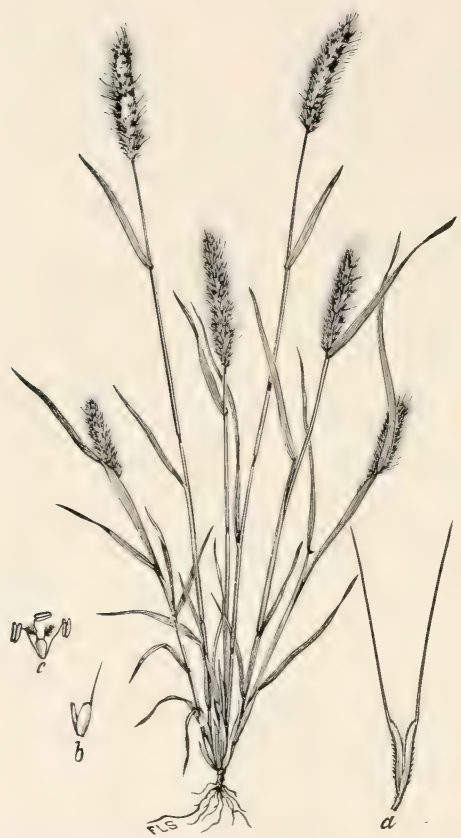

FIG. 132. Polypogon monspeliensis (L.) Desf. Brard(iRAss. - A smooth annual from a few centimeters to 6 to $9 \mathrm{dm}$. high, with awned 1-flowered spikelets crowded in dense spikelike panicles.-In fields and waste places, sparingly naturalized along the Atlantic Coast from New Hampshire to South Carolina; abundantly on the Parifi. Slope from California to Vaneonver Island, and in Arizona, Nevada, and Colorado. [Europe and Asia.] April-Oetober. 


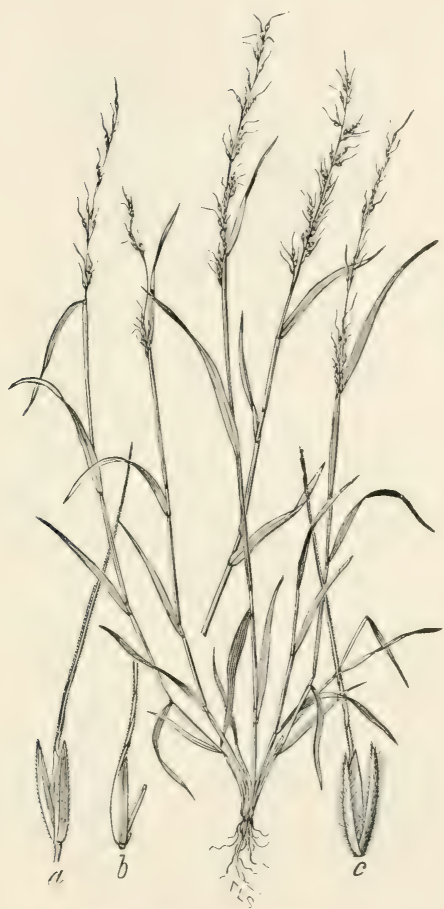

FI(i, 133. Limnodia arkansana (Nutt.); Dewey in Contrib. U. S. Nat. Herh., 2: 518 (Greeniu arlansana Nutt.; Thurberia arkansuna Benth. ). - A sleurler aumual 2 to 6 dm. high, more or less geniculate at the lower nodes, with soft, hat leaves and narrow, lonsely flowered panieles 8 to $18 \mathrm{~cm}$. long. Onter glumes scabrous or pilose. - Shell banks, woods, "te., westeru florida to Arkansas and southern T'exas. April-June. 


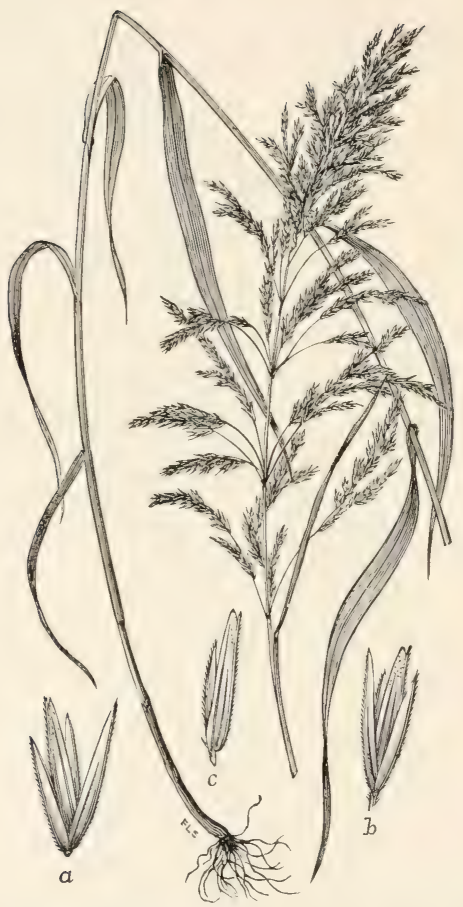

Fig. 134. Cimna arundinacea L. Ixniax REed.-A tall, leaf $y$ grass 9 to $21 \mathrm{dm}$. high, with simple culms, llat leaf blades, and ample terminal pauicles.-Shated swamps, banks of streams and low thickets, Newfonndland to North Carolina, Alabama, Texas, South Dakota, and the Northwest Territory. May-September. 


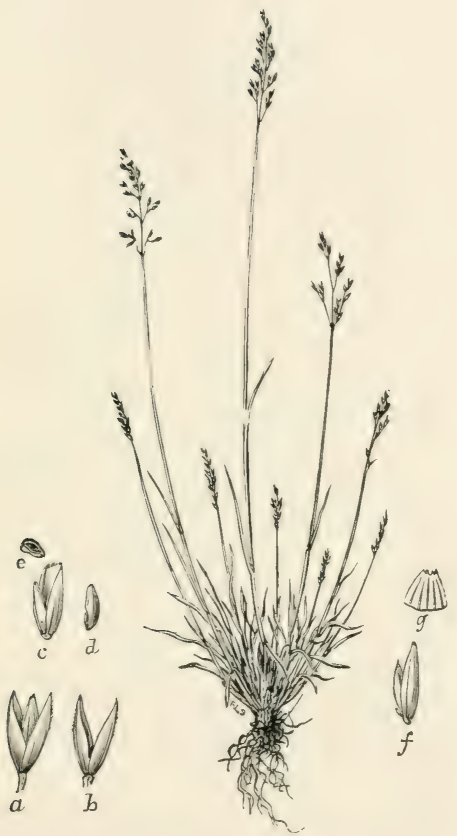

Fig. 135. Agrostis humilis Vasey (A. varians Trin.? not Thuill.). -A dwarf, slender perennial 6 to $12 \mathrm{~cm}$. high, with short, flat leaves and contracted, purplish panicles'2 to $3 \mathrm{~cm}$. long.-Moist meadows, or mossy and springy places, at 2,100 to $3,000 \mathrm{~m}$. altitude on the mountains of Colorado. Wyoming, Washington, Oregon, and Montaua. August, September. 


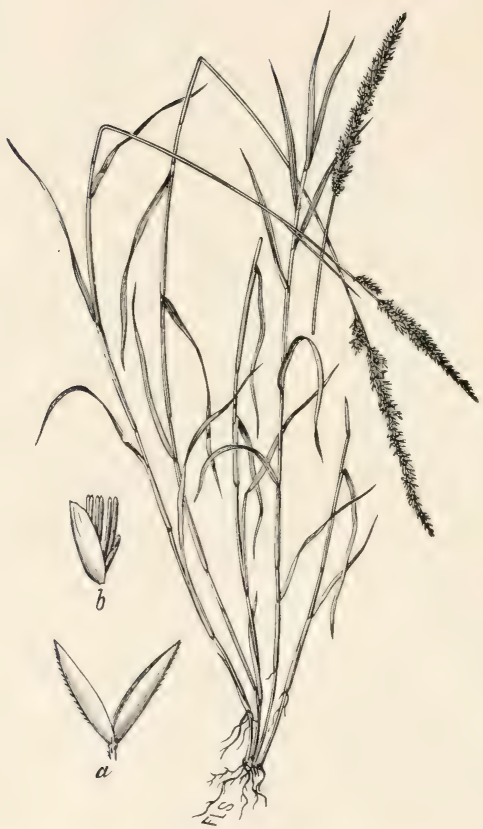

FIg. 136. Agrostis coarctata Ehrh. (Stolonifera coarctata Reichb).-A ereeping perenuial with slender culms, the upright branches about $3 \mathrm{dm}$. high, short, tlat leaves and narrow, rather densely flowered panicles 5 to $10 \mathrm{~cm}$. long. -Damp soil and sunds along the coast, Newfoundlaud to New Jersey. [Enrope.] JulyOctober. A fine-leafed, excellent turt-forming speeies, valuable for lawns. 


\section{5}

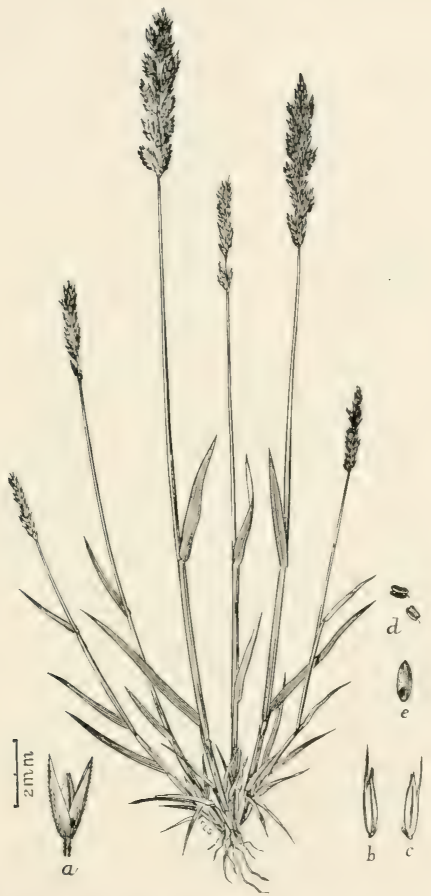

Fir. 137. Agrostis densiflora Vaser; Contril, I'. S. Nat. Herb.,

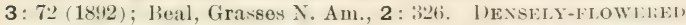

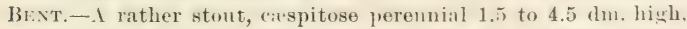
with short and eomparatively hroal leaves and densely, manyflowered, almost spike like panicles : to s cm. long. - Oregon and California, along the coast, apparently rare. July, Lugust. 


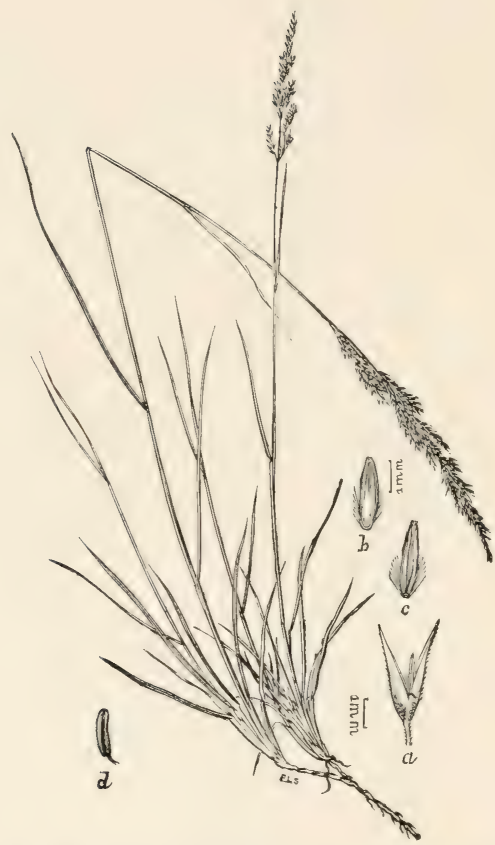

FIG. 138. Agrostis pringlei Seribn. sp. nov.-A strongly stoloniferous grass, with rather slender, upright or ascending culms 3 to $6 \mathrm{dm}$. high, narrow and rather rigid flat leaves, and loosely Howered, narrow panicles 5 to $15 \mathrm{~cm}$. long. Flowering glumes much shorter than the acuminate outer ones, and remarkable for the long hairs on the eallus.-Plains, Mendocino County, California (Pringle), and northward to Oregon (?). August. 


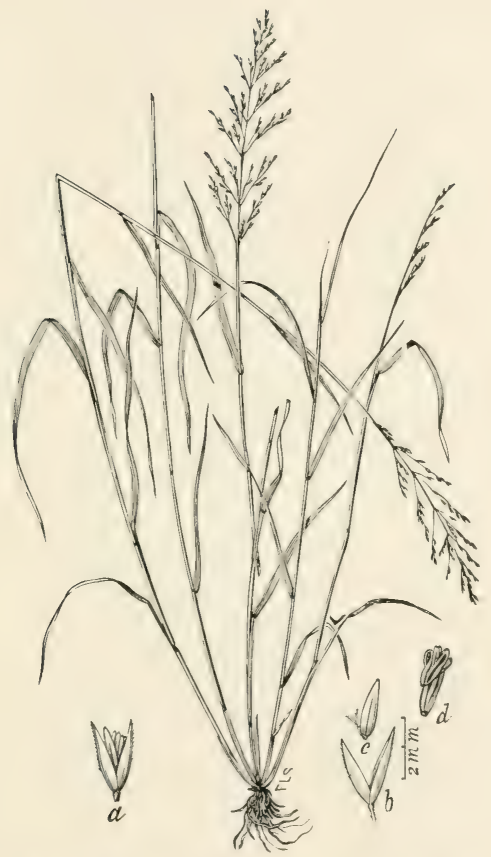

Fig. 139. Agrostis diegoensis Vasey (A. foliosa Vasey); lieal, Grasses N. Am., 2 : 328.-A strong-growing, leafy perennial 6 to 10 dul. high, from ereeping rootstocks, with palo-green, narrow, and many-1lowered panicles 15 to $20 \mathrm{~cm}$. long. Spikelets 2 to $3 \mathrm{~mm}$. long; flowering glume short-awned or awnless; palea wanting.Mountains of southern California to Washingtou. May-August. 


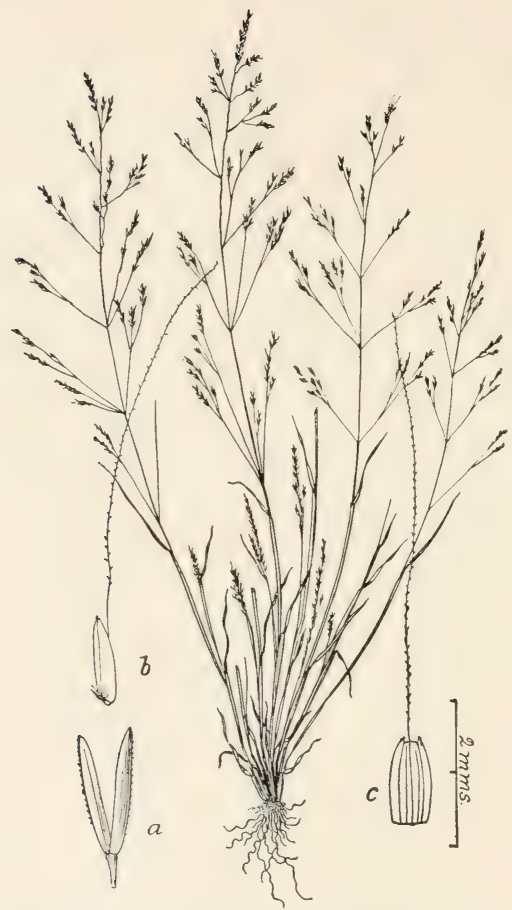

FIG. 140. Agrostis elliottiana Sehnlt. (A. arachnoides Ell.). Spmer Bent-grass.-A low, branching annual, rarely exceeding 3 dm. high, with narrow, tlat leaves and ditiuse, capillary panicles. The flowering glume bears a long and very slender awn.-Dry hillsides and old fields. Sonth Carolina to Kentucky and Missouri, south to Florida and Texas. April, May. 


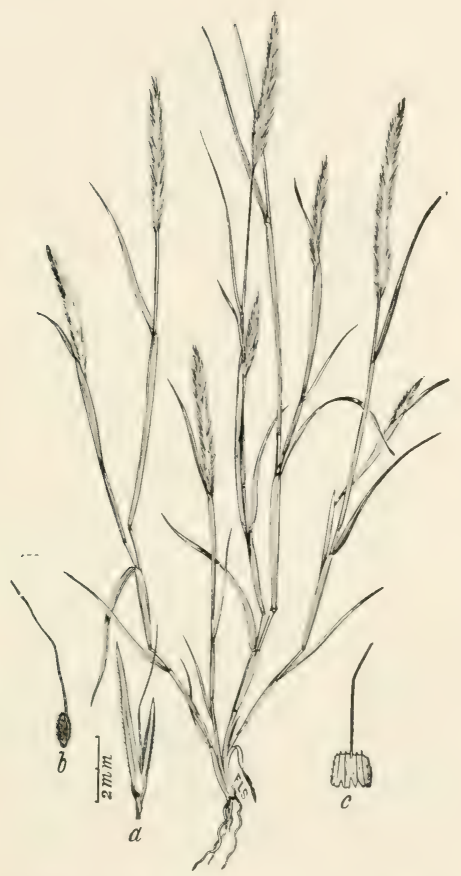

FIG. 111. Gastridium lendigerum (I.) Gaullin, (fr. australe Beaux.; Milium lendigerum Linn.). Nit-(ilass.-A smooth aumul 1.5) to $6 \mathrm{im}$. high. with flat leaves and a strict, spike-like panicle 6

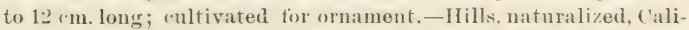
fornia and Orogon: also in Toxas. [Southern Europe.] June, July. 


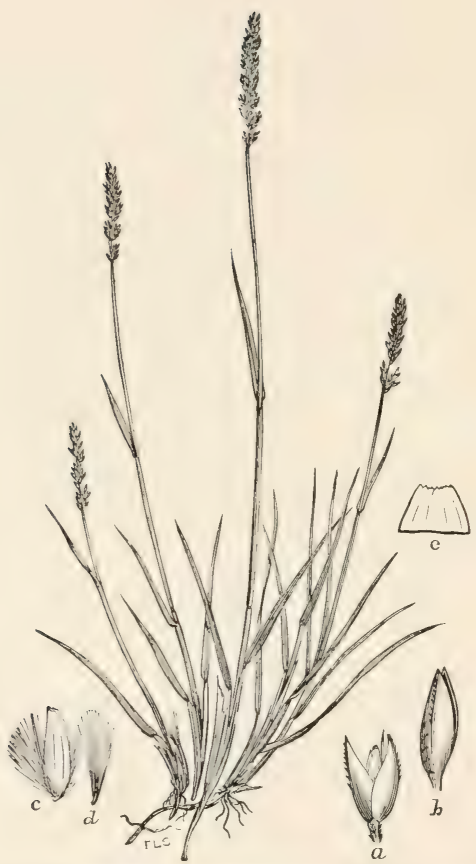

FIG. 142. Calamagrostis crassiglumis Thurb.; Beal, Grasses N. Am, 2 : 353 (as a var. of C. neglect 1 ). - A rigid, erect perenuial 1.5 to $4 \mathrm{dm}$. high, from creeping rootstorks, with long basal leaves and dense, oblong, spike-like panicles 4 to $6 \mathrm{~cm}$. long. - Wet ground and gravelly lake shores, Califoruia to Vancouver Island. July, August. 


\section{1}

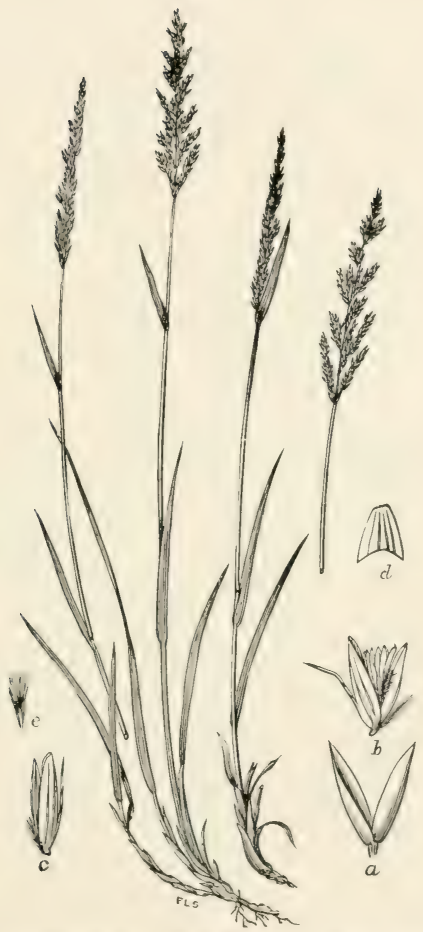

FIt, 14:3, Calamagrostis breviseta (A. Gray) scrilm.; Britton

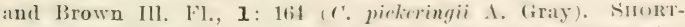

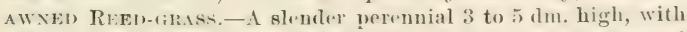
flat leaves and narrow or subpramidal, rather donsely flowered purplish panicles 8 to $12 \mathrm{~cm}$. Iong.-Moist gromud. Now fomblland, Cape Breton Island, and Lahrador to New Ilampshire, Vermont, and Massachusetts. July, August.

$11162-$ No. $7-11$ 


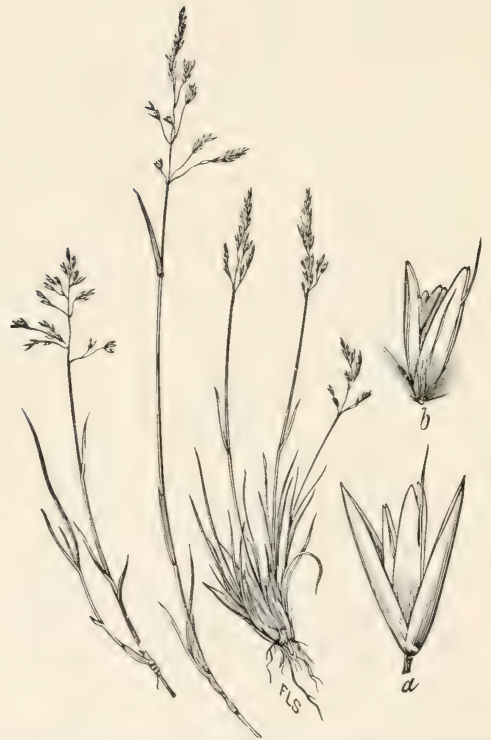

FIc. 144. Calamagrostis deschampsioides Trin.; Beal, Grasses N. Am., 2 : 339.-A slender perennial with culms 1.5 to $3 \mathrm{dm}$. high, from creeping rootstocks, with narrow leaves 3 to $7 \mathrm{~cm}$. long and open, pyramidal panicles 4 to $8 \mathrm{~cm}$. long.-Pribilof Islands, Alaska, sonthward to California. [Kamchatka.] August. 


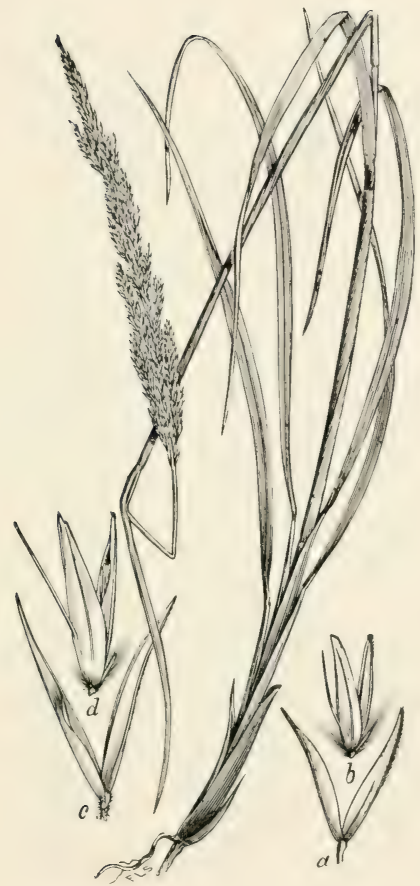

Fin, 145. Calamagrostis aleutica Triu.; Iieal, (irasses N. Am., 2 : $346 .-\Lambda$ stont, erect perennial 6 to $15 \mathrm{dm}$. high, with long and rather stiff, llat leaves and densely many-llowered, narrow panicles 15 to $30 \mathrm{~cm}$. long.- Ilong the seashore, in rocky or marshy places, Alaska and Unalaska to ('alifornia. Jume-september. 


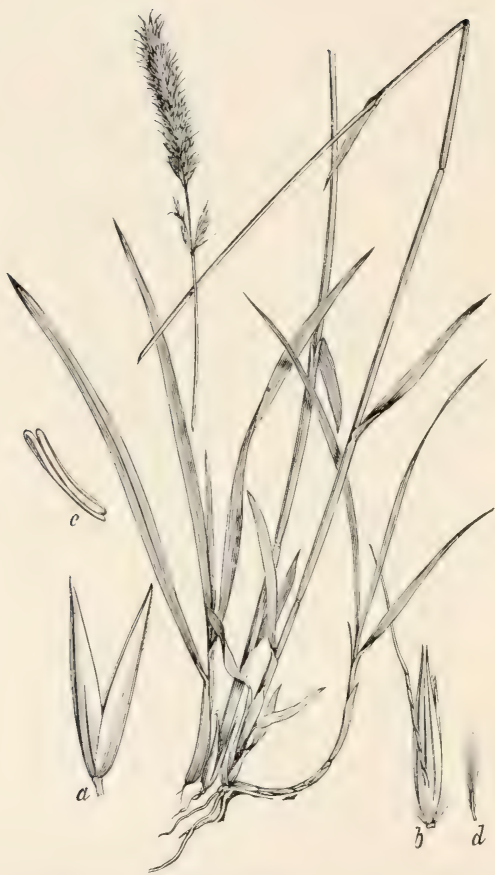

FIG. 146. Calamagrostis tweedyi Suriln. ; Beal, (irasses X. Am., 2 : 348 . - A stont perenuial 7 to $10 \mathrm{dm}$. high, with rather broad, tlat leares and densely flowered, spike-like panieles 8 to 12 $\mathrm{cm}$. long.-Cascade Mountains, Washingtou. 


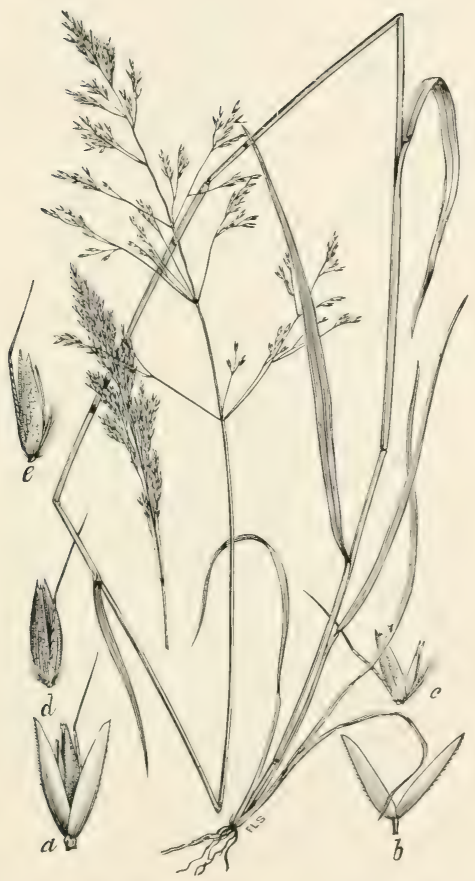

F1:. 147. Calamagrostis bolanderi Thurl, ; Beal, (irasses X. An., 2 : 35\%.- - A stout perennial 6 to $15 \mathrm{dm}$. ligh, with flat leaves 10 to $30 \mathrm{~cm}$. long and oxpanded, dark-purple panicles 8 to $20 \mathrm{~cm}$. long.-Moist wodlands, northwesteru California. August. 


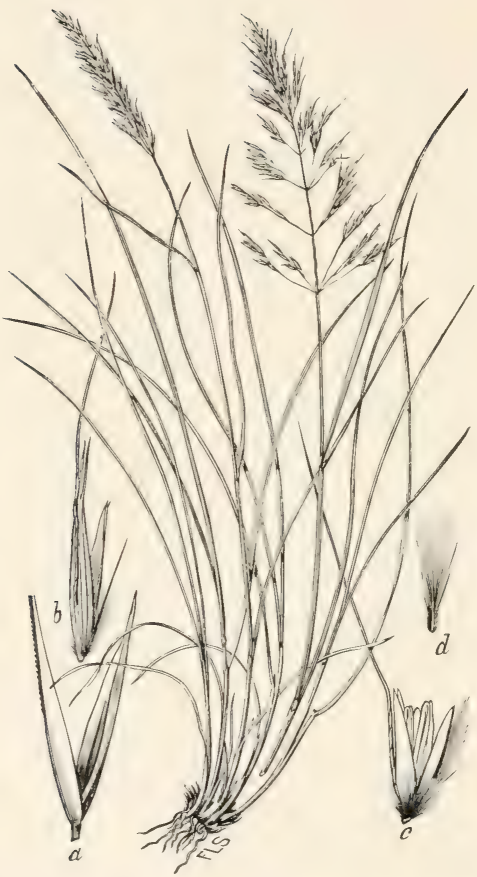

FIG. 148. Calamagrostis howellii Vasey; Beal, (irasses N. Am., 2: 339. - A densely caspitose, erect, leafy perennial 2.5 to $5 \mathrm{dm}$. high, with long and narrow basal leaves and open panicles 8 to 15 cm. long. Spikelets long-awned.-High mountains, Oregon and Washington. June-August. 


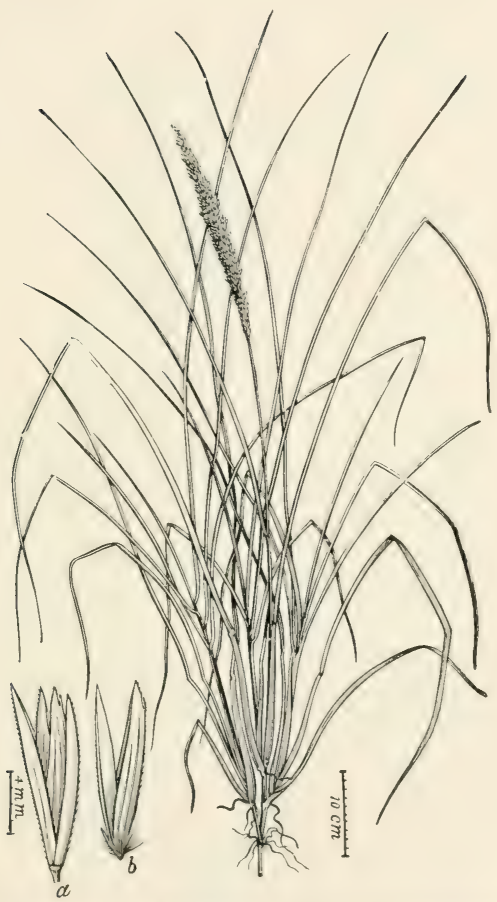

Frg.149. Ammophila arenaria (L.) Link (. L. arundinacea Host.). BEACH-GRARs, MARIRM-Grass. - A coarse, ercet perennial, with creeping rootstocks, rigid culus 6 to $12 \mathrm{dm}$. high, long leaves, and narrow, densely Howered, spike-like terminal panicles 12 to $25 \mathrm{~cm}$. long.- Sandy coasts of the Atlantic from Now Brunswick sonth to Virginia, and shores of the (ireat lakes. [Europe.] JulyOctober. 


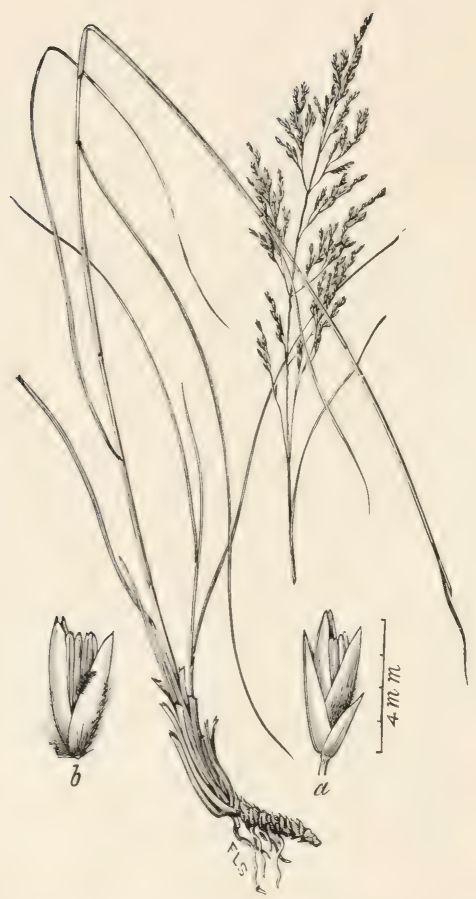

Fr(. 150. Calamovilfa brevipilis (Torr.) Acribn. (Arundo breripilis Torr.). SHort-HanRen REED-tilass.-A rather slender, smooth perennial 9 to 12 dm. bigh, with very narrow leaves and open panicles 8 to $24 \mathrm{~cm}$. long. - Sandy swamps in the pine barrens of New Jersey. August, September. 


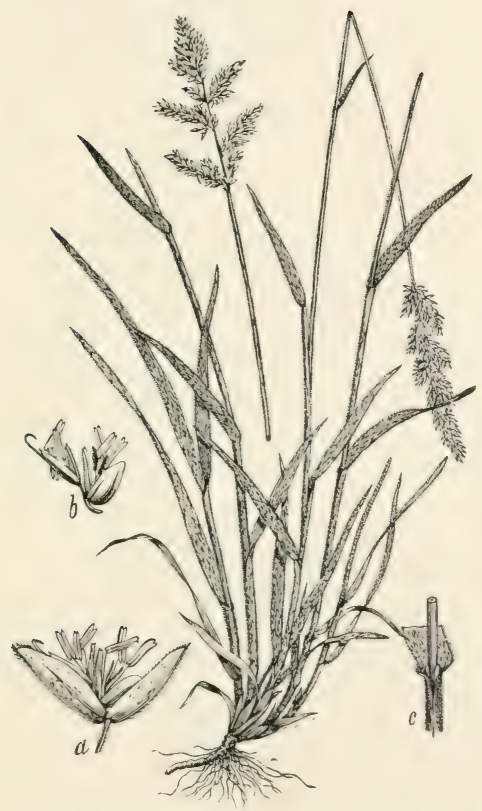

Fin. 151. Holcus lanatus L. Veuret firass.-A peremuial 3 to 6 dun. high, with creeping rootstocks, flat leaves, and open panicles 5 to $x$ em. long; usually densely pubescent all over with soft, whitish hairs.-Introduced into this country from Europe with other grasses and now widely distributed. May-Ingust. 


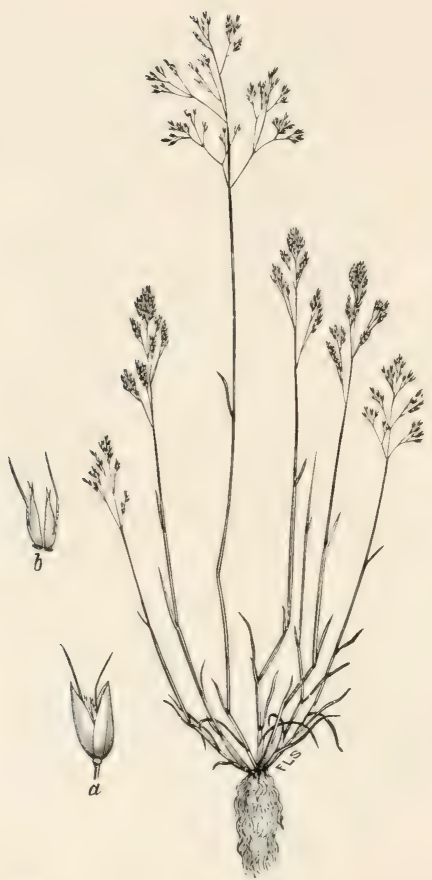

Fig. 152. Aira caryophyllea L. Silveir Hali-grass,-A slender, tufted annual 1 to $3 \mathrm{dm}$. high, with short leaves and small-flowered, open panicles 2 to $8 \mathrm{~cm}$. long.-In sandy waste places, Massachusetts to Virginia; also on the Pacific Coast. Introduced from Europe. May-August. 


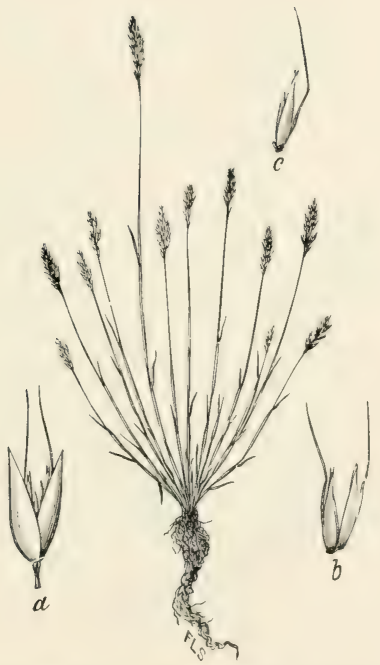

Fig. 153. Aira præcox I. Eariy Wild OAT-grass.-A tufted, erect or ascending annual 2 to $12 \mathrm{~cm}$. high, with a contracted panicle 1 to $2 \mathrm{em}$. long.-Introduced aud sparingly distributed in the Middle states near the coast, growing in sandy soil. Also on Vancouver Island. [Europe.] May-July. 


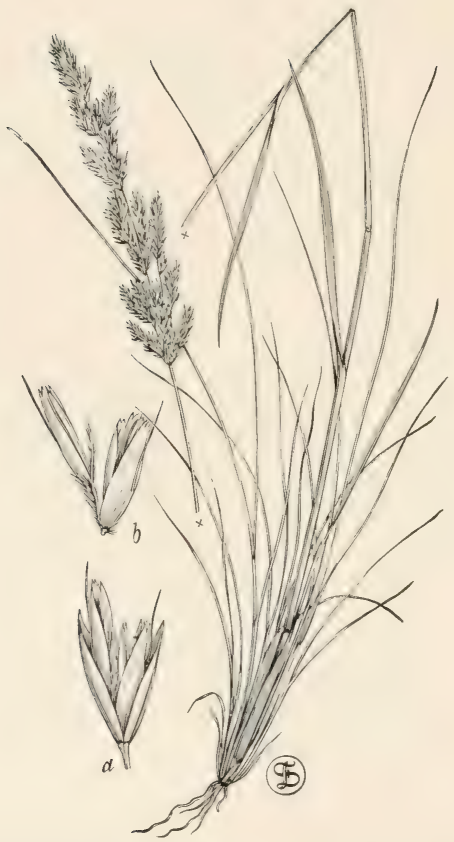

Fig. 154. Deschampsia holciformis Presl.; Real, Grasses N. Am., 2 : 370. CaIfforian Halli-gliass.-A stout, erect perennial 6 to $15 \mathrm{dm}$. high, with long and rather rigid hasal leaves and densely thowered, more or less interrupted panicles 12 to $24 \mathrm{~cm}$. long.-Moist meadows, C'alifornia near the coast. April. 


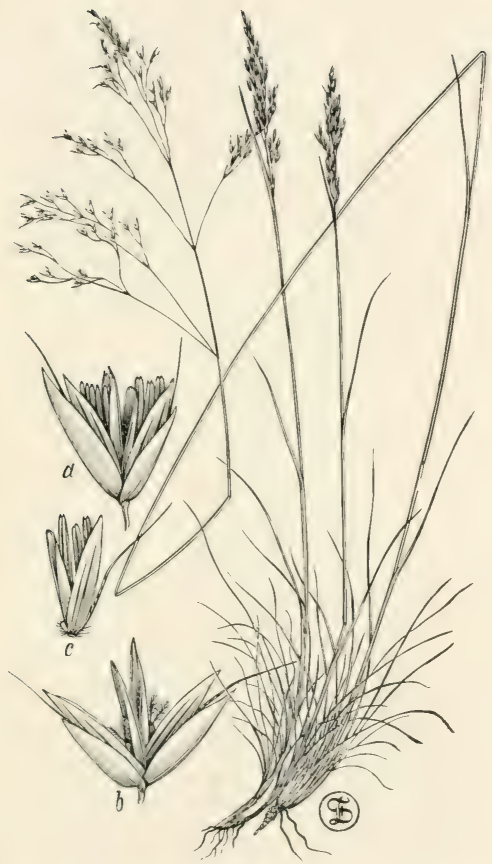

Fir. 155. Deschampsia flexuosa (L.) Trin. Trrten IlairGrass. - A slender, erect perennial alvont bim. high, with involutesetaceous, radical leaves and difinse panicles.-Labrador southward along the mountains to North C'arolina and Temmessere, and westward from New York to Wisconsin. [(ireenland aml Europe.] May-August. 


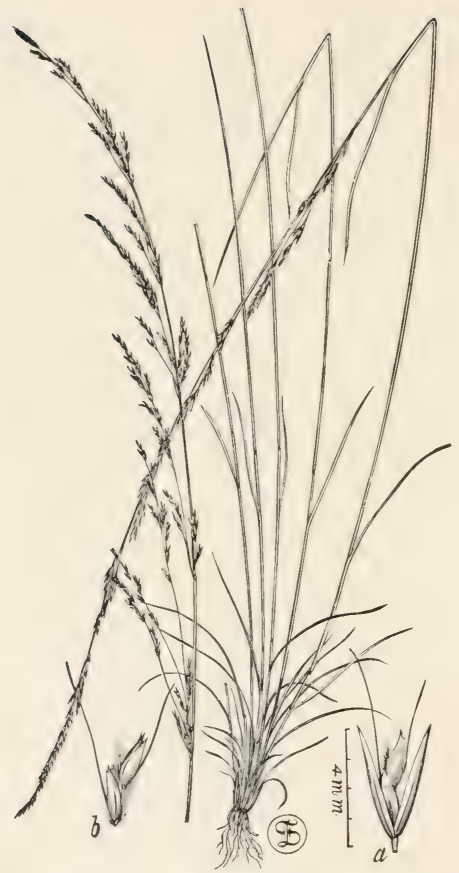

FIr. 156. Deschampsia elongata (Hook.) Munro; Beal, Grasses N. Am., 2: 371. Slexider Hair-grass.-A slender perennial 3 to 1ㄹ du. high, with narrow panicles 15 to $38 \mathrm{~cm}$. long.Montaua to British ('olumbia and southward on the Pacific slope to Mexico. May-August. 


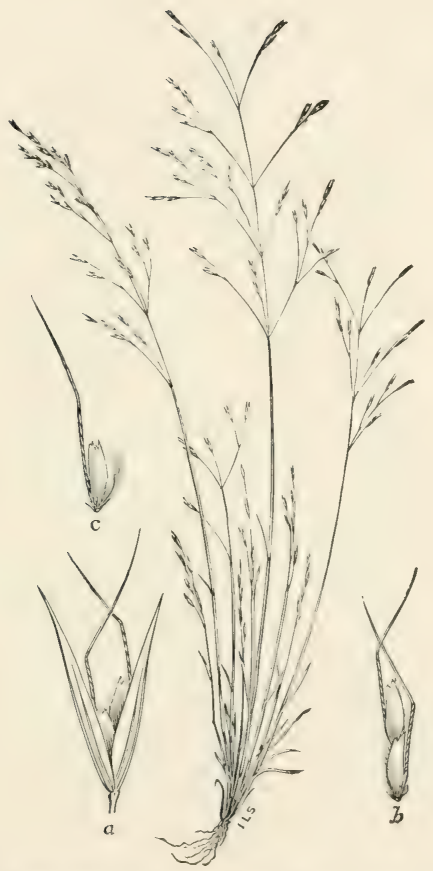

FI, 157. Deschampsia calycina Presl (.tirt denthonioides

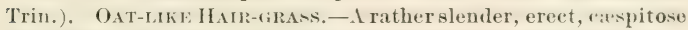
grass from $1 \mathrm{to} 7 \mathrm{dm}$. high, with more or less spreading panicles.Nativo along the Parific slope from C'anala to ('alifornia, eastward to Ctah, and southward through Mexico to Peru. AprilJuly. 


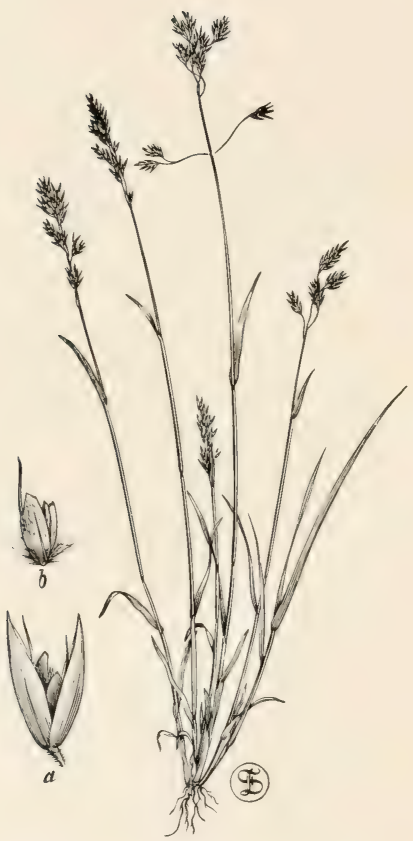

Fic. 158. Deschampsia atropurpurea (Wahl.) Scheele. MounTAIN IIAMr-iRAs..-A slencler, alpine grass 1.5 to 4 ،lm. high, with flat leaves and few-flowered, noilding panicles 3 to $12 \mathrm{~cm}$. long.Labrador, White Mountains, Adirondacks, Rocky Mountains in Coloraio, northward to Alaska. [Northern Lurope and Asia.] July-September. 


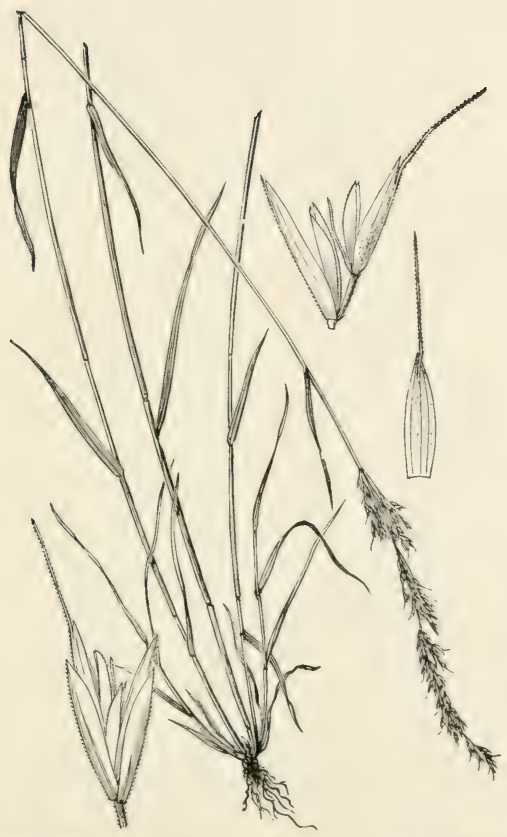

Fir. 159. Trisetum palustre (Michx.) Torr. MARsi OATGrasis,-A slender, loosely tufted premnial 6 to 9 , dm. high, with flat, soft leaves and loosely flowered, nodding, and yellow ish green panicles. - on moist rocks, along hrooks, in wet meadows, etc., Alassarhusetts to Illinois, south to Florida and Louisiana; British Columbia. April-June.

$11162-$ No. $7-12$ 


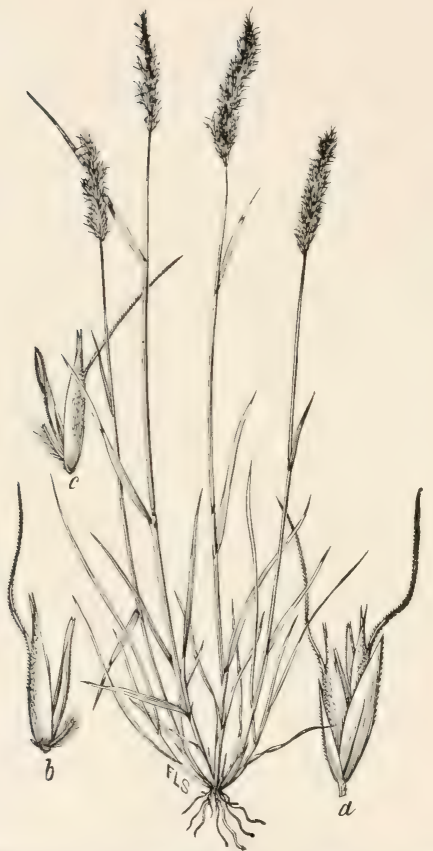

Frg. 160. Trisetum subspicatum (L.) Beauv. (Aira subspicata L.). Downy OAT-Grass.-A slender, erect perennial 1.5 to 4.5 dm. high, with usually downy culms and leaves and densely many-flowered, spike-like panicles.-Widely distributed in the cooler temperate regions of both hemispheres, ranging in North America from Labrador to Alaska and extending southward in the Eastern States to the mountains of North Carolina and Tennessee, and in the West to New Mexico and California. June-September. 


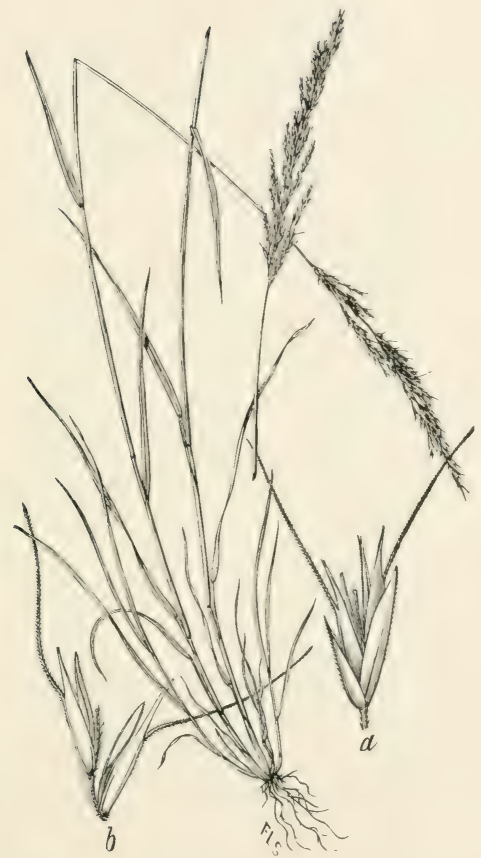

FI(r. 161. Trisetum montanum Vasey ; Beal, Grasses X. Am., 2 : 379. Rocki Morntaix OAT-GRass. - I slender, ereet, or ascending native grass 3 to 8 dul. high, with narrow, llat leaves ant many-flowered. more or less contracted panicles 8 to $12 \mathrm{~cm}$. Jong.Momatains of Colorado and Now Mexico. July, August. 


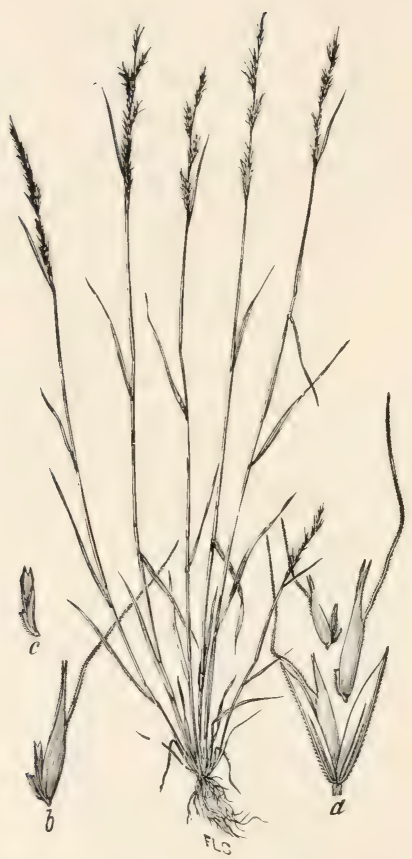

Fir, 162. Trisetum interruptum Buckl.; Beal, Grasses N. Am., 2: 376, under $T$. elongatum. SLENDER ()AT-(iRAss.-A sleuder, erect annual 2 to $5 \mathrm{dm}$. high, with rather short, soft leaves and narrow, elongated panicles 4 to $10 \mathrm{~cm}$. long.-Colorado to Texas, Arizona, and southern California. March-May. 


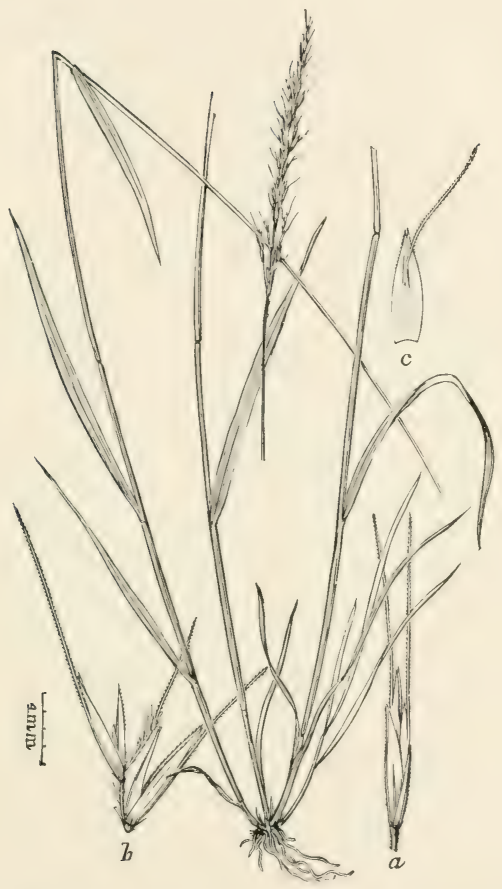

FIG. 163. Trisetum canescens Bnckl.; Brewer and Wats., Bot. Calif, 2 : 296. SnderY OAT-GRass.-An erect perennial 3 to 12 dho. high, with flat leaves, and more or less densely flowered pauieles 12 to $18 \mathrm{~cm}$. long.-Indry, open ground, open woods, thieliets, and wet meadows, California to Iritish Columbia, east to Montana. May-September. 


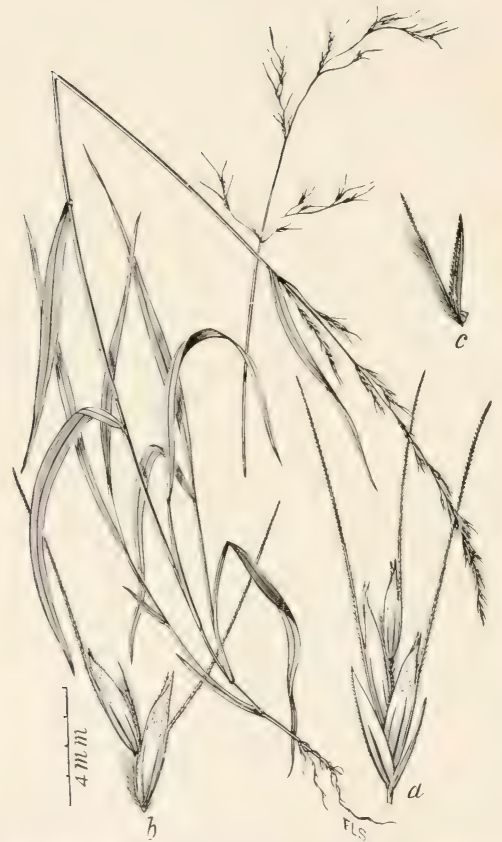

Fig. 161. Trisetum cernuum Trin.; Beal, (trasses X. Am., 2 : 379. Xondixi ()AT-4isiss. - A slender perennial 6 to 10 dm. high, with rather hroad, flat leaves and loosely flowered, nodding panicles 12 to $20 \mathrm{~cm}$. long. - Mlaska to northern California and eastward to Idaho. May-July. 


\section{3}

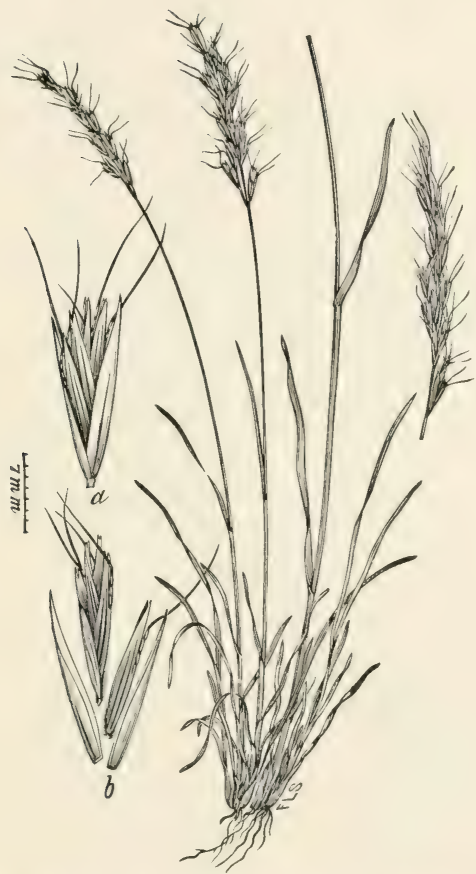

Fif. 16.5. Avena americana (Scribn.) (.1. pratensis var. ameri-

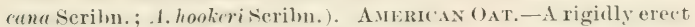
perennial 3 to $(\mathrm{i} \mathrm{dm}$. high, with narrow, firm leaves, and contracted panicles 8 to $12 \mathrm{~cm}$. long.-Open thickets and prairies, Manitoba, and in the foothills of the Rocky Mountains southward to Colorado. June-August. 


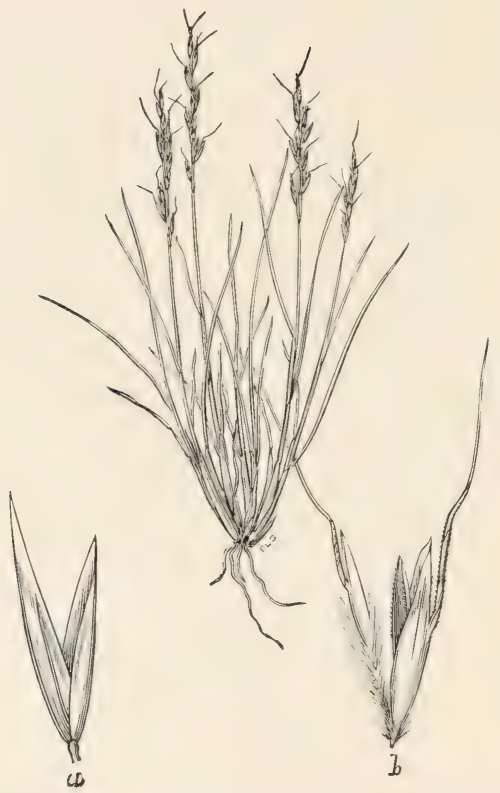

FIg. 166. Avena mortoniana Scribn.: Bot. Gaz., 21: 133. Mortox's OAT-(irass. - A densely cirspitose, erect perennial 1 to $2.5 \mathrm{dm}$. high, with rather rigid leaves and narrow, simple panicles of one- to two-1lowered spikelets.-At 3,900 to 4,200 m. altitude, mountains of Colorado. August. 


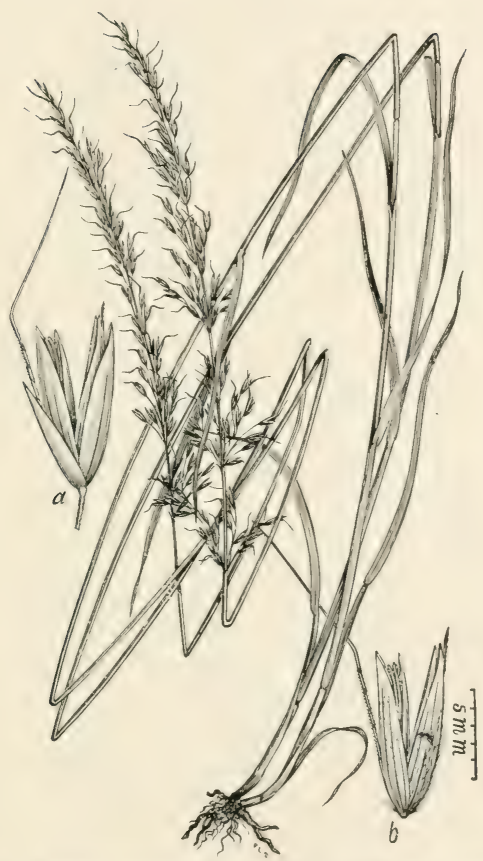

FI(i. 167. Arrhenatherum elatius (L.) Beauv. (trena elatior I..). TaLL OAT-(ik.1ss.-A loosely tufted peremnial it to $12 \mathrm{dm}$. high, with flat leaves and narrow, loosely flowered panicles 15 to 20 ('m. long.-Introduced from Enrope as a fodeler erass. Valuable; in Europe regarded as one of the hest meadow grasses. May, June. 


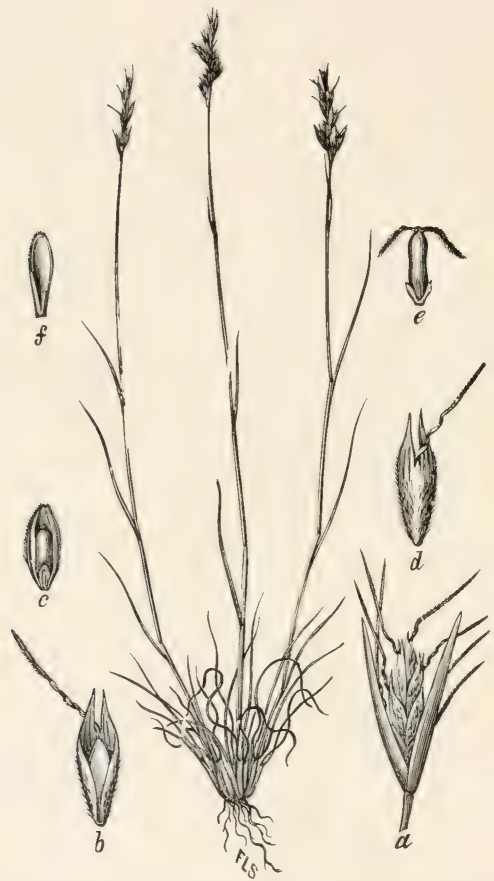

Fig. 168. Danthonia spicata (L.) Beauv. (Arenu spicata L.). WILD OAT-GRASs.-A smooth, slender, erect perennial 2.5 to $5 \mathrm{~cm}$. high, with a few-flowered, narrow panicle spreading only in flower.-Common in drs, thin soils from Camada southward to the Gulf States and westward to Texas. May-September. 


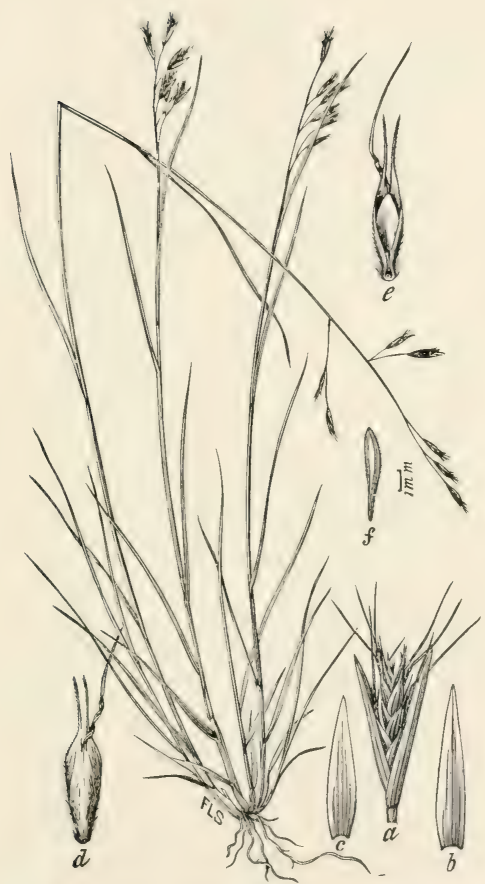

Fig. 169. Danthonia compressa Austin. Texsessfe O.IT(ilisss. - A sleuder, erect, tufterl perennial 2- to 6 dm. high, with long, narrow root leaves, and tew-llowered open panicles.-Monntain regions of castern Tennessee and North Carolina nortloward to Canada. June-August. 


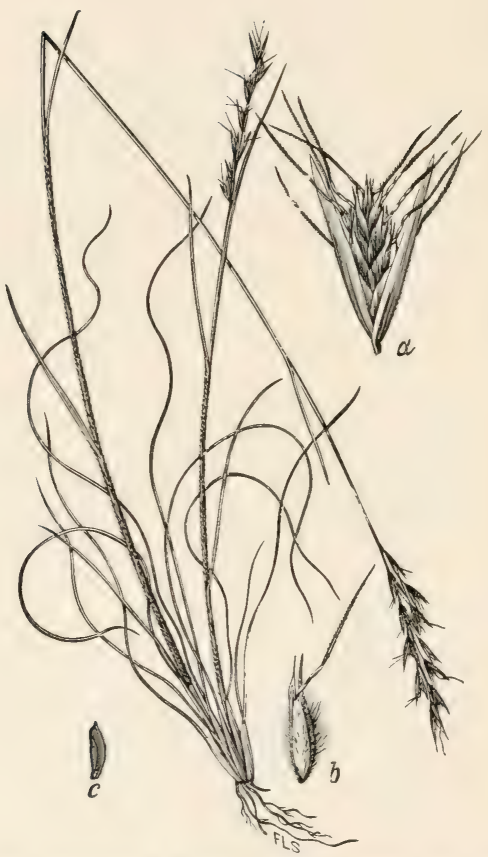

FIG. 170. Danthonia sericea Nutt. Silkx OAT-grass,-A rather stout, ereet perennial 3 to $9 \mathrm{dm}$. high, with usually pubescent sheaths, rather rigid leaves, large spikelets, and terminal, few-flowered panicles.- Open woodlands in dry soil, Massachusetts and New Jersey to Florida and west to Tennessee and Alabama. May, June. 


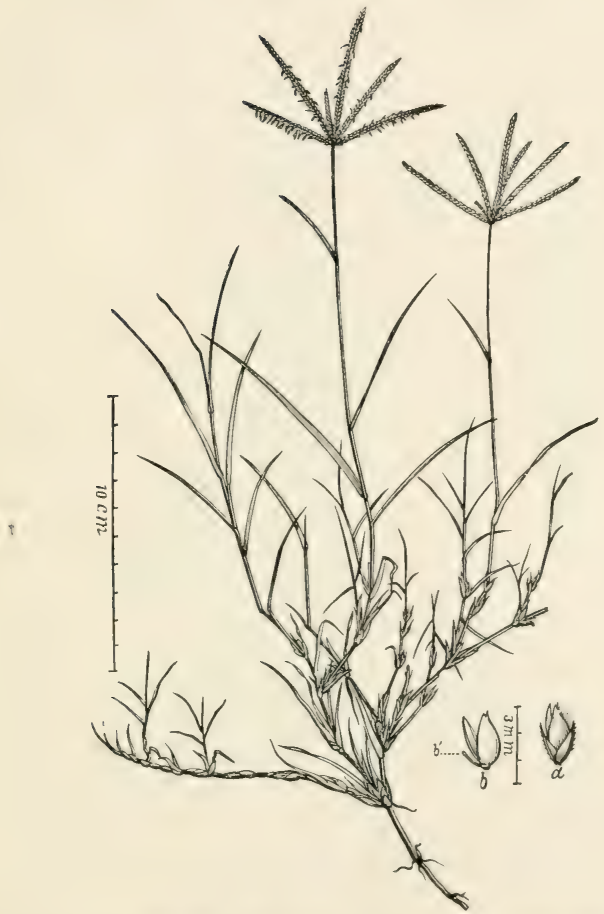

Frr. 171. Capriola dactylon (L.) Kuntze (l'anium ductylon L.; Cynodon dactylon Pers.). Bremuda-dirass.-A (reeping perennial, with upright or ascending, leafy flowering branches 1 to $6 \mathrm{dm}$. high.-Wirlely dispersed over the tropical and warmer temperate regrions of the world, in the Uniterl states from I'ennsylvania southward to Florida and westward to Texas and ('alifornia. Ipril()tober. (The name Cupriola may belon⿺ to I'anicum sanguinale.) 


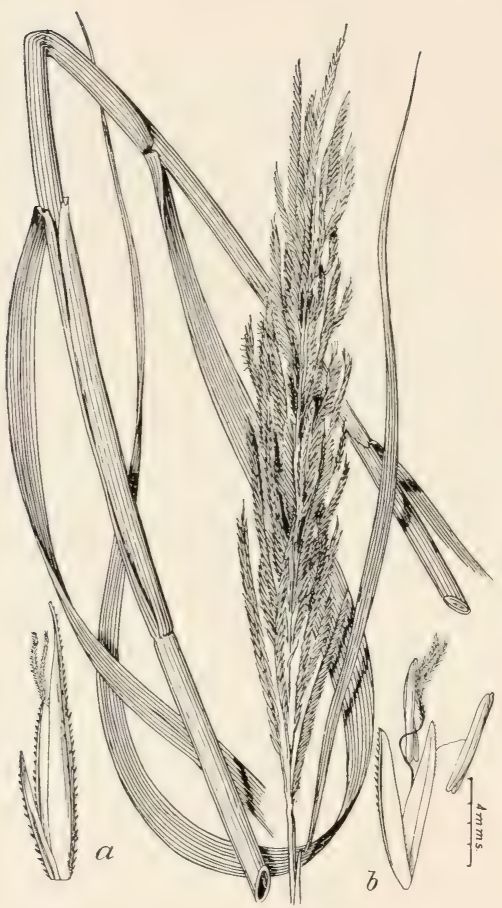

FIG. 172. Spartina polystachya (Michx.) Ell. (Trachynotia polystachya). SALT REED-GRASs. - A stout, erect perennial 12 to $27 \mathrm{dm}$. high, with loug, flat leaves and terminal panicles of twenty to fifty crowded, ascending spikes 5 to $10 \mathrm{~cm}$. long.-Brackish marshes along the coast, Maine to Mississippi. July-Oetober. 


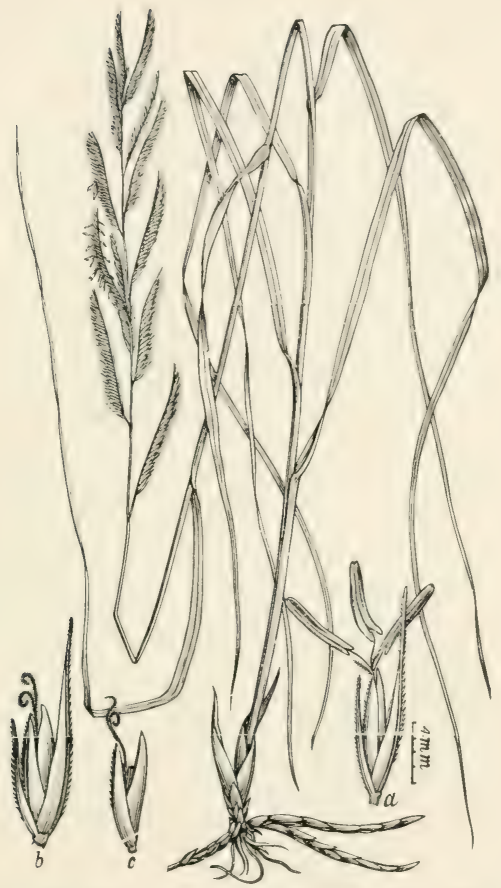

Fir. 173. Spartina cynosuroides (L.) Willd. Frishwater Cond)-(iliass.- I stout, erect grass 6 to $1 \times$ dm. high, with unbranched, smooth culms from strong, scaly, creping rootstocks, long, tongh leaf biales, and tive to twenty spikes, forming at terminal panicle.-liver hanks and lake shores, also brackish coast marshes, Maine and Nova ficotia to Assiniboia and ()recon, south to New Jersey, western Tennessee. Texas, and ('olorado. JulyOctober. 


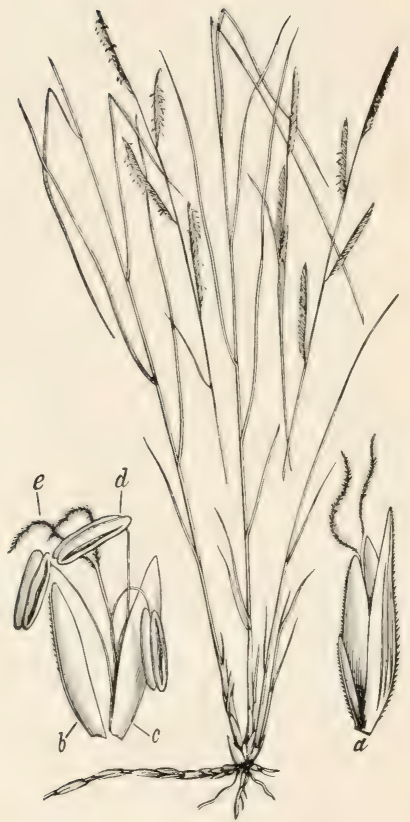

FIG. 174. Spartina patens (Ait.) Mull. (I) Mctylis patens Ait.; Spartina juncer Ell.). Fox-Gilass.-A rather slender and somewhat wiry grass 3 to 6 (rarely 9) dm. high, with two to four slender, erect or widely spreading spikes.- Salt marshes aud sandy shores along the coast from Newfonndland to Florida and westward to Texas. June-September. 


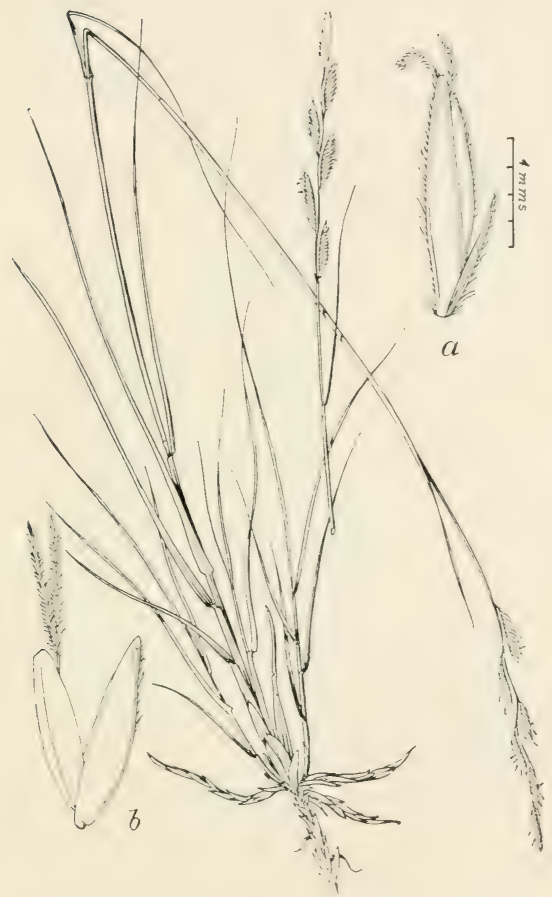

Fir. 175. Spartina gracilis Trin. Westerx ConH-grass.-A comparatively slenter, perennial species 3 to $9 \mathrm{dm}$. high, with flat leaves, and three to nine rather short, appressed spikes.-Meatows. swamps, and river bottoms, especially in allialine soils, somth I)akota to Kansas, west to British Columbia, Nevada, and California. March-August. 


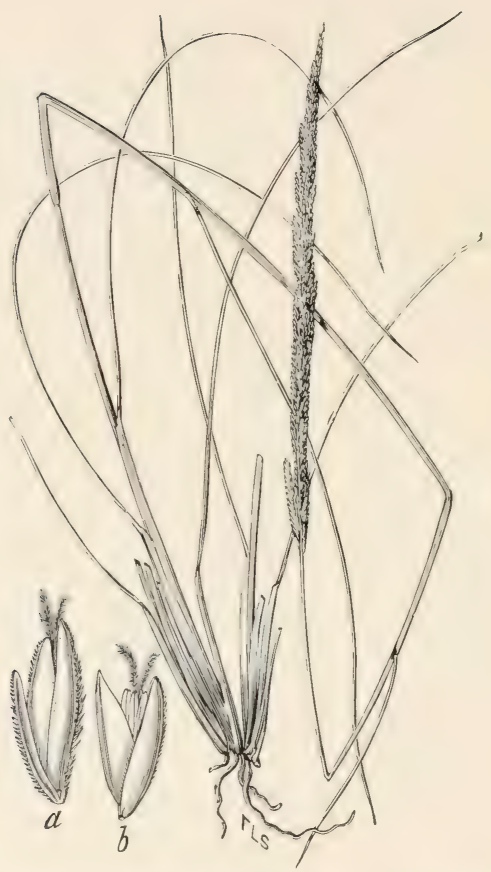

FrG. 176. Spartina junciformis Engelm. \& Gray ( $S$. densiflora Brongu. (?); S. gonini Fourn.); Beal, Grasses X. Am., 2 : 400. RISH-LIKE SPARTINA.-A stout perennial 6 to $15 \mathrm{dm}$. high, with very long, narrow leaves and short, appressed spikes, which form a cylindrical, spike-like inflorescence 10 to $30 \mathrm{~cm}$. long.-Brackish marshes along the fiulf Coast, Key West, Florida to Texas. [Mexico and Chile.?] June-Octoier. 


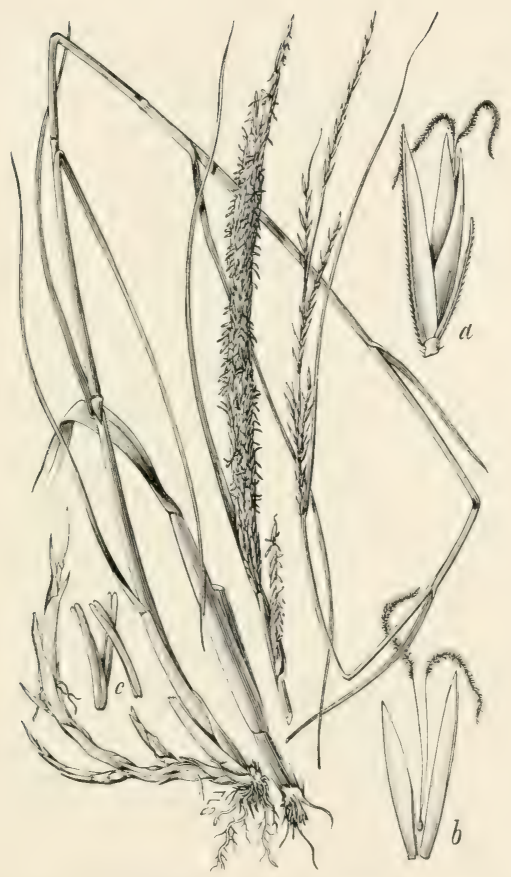

FIf. 177. Spartina stricta maritima (Walt.) Seribn. (Iuctylis maritima Walt.: Spartima glabra Muhl.). ('1:1:EK SEncie or Tuıт (1. - In erect and often stont salt-marsh grass from 6 to 21 dm. high, with long. Hat leaves and few to many, erect, appressed spikes. - Ilong ditches and creelss of the salt marshes of both the Atlantic and Pacific coasts. July-October. 


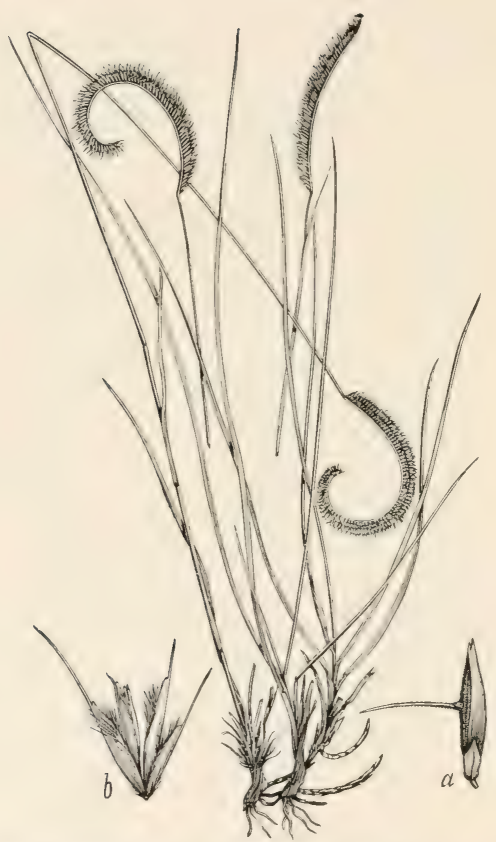

Fig. 178. Campulosus aromaticus (Walt.) Trin. (.Filops arometica Walt.; Ctenium ameriranum spreng.). Toothacme(iliss.-An erect perennial 9 to 12 dul. high, from strong, lemonscenterl and pungent rootstocks, with narrow leaves and usualiy a single, terminal, curvel. pectinate spike \& to $10 \mathrm{~cm}$. long.fouthern Virginia to Florida and westwarl to Mississippi. July, August. 


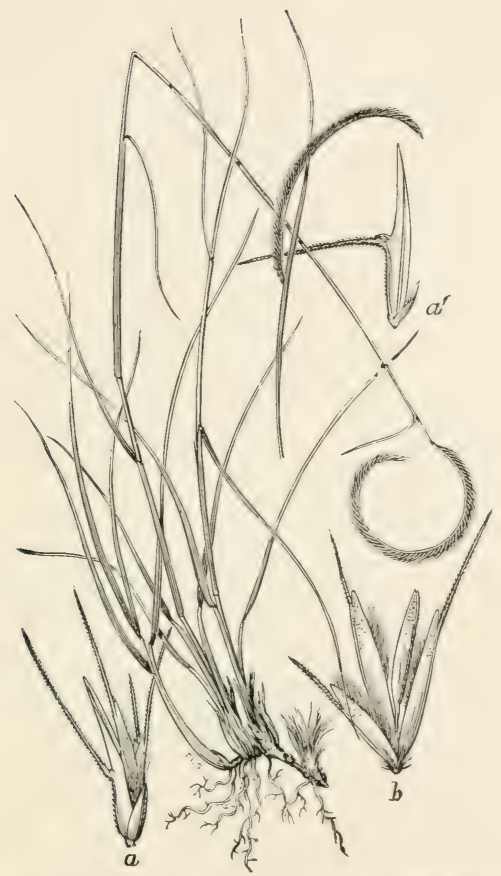

Fig. 179. Campulosus chapadensis Trin. (Tenium chapadense Doell).-An ereet perrnnial $\times$ to $12 \mathrm{dm}$. high, with narrow leaves and usually single, terminal, more or less curved spikes. Mor" slender than ('. aromaticus, with narrower glumes, and more delicate and longer awns.-Florida, $1 n$ the "flat woods" regions. July-October. 


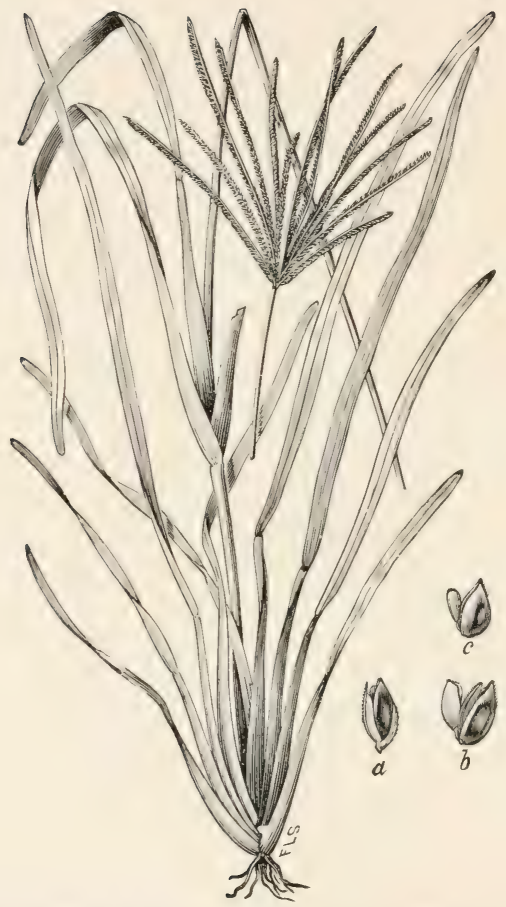

Fir. 180. Chloris glauca (C'hapm.) Vasey (Eustachys glauca (hapm.); Beal, Grasses N. Am., 2: 408. Sмоотн Chloris.-A strong-growing pereunial, with diffusely spreading and ascending culms 6 to $12 \mathrm{dm}$. long, hearing 10 to 25 slender terminal spikes. Culms and sheaths strongly tlattened.-Brackish marshes aud along the borders of eypress swamps, Florida. July-September. 


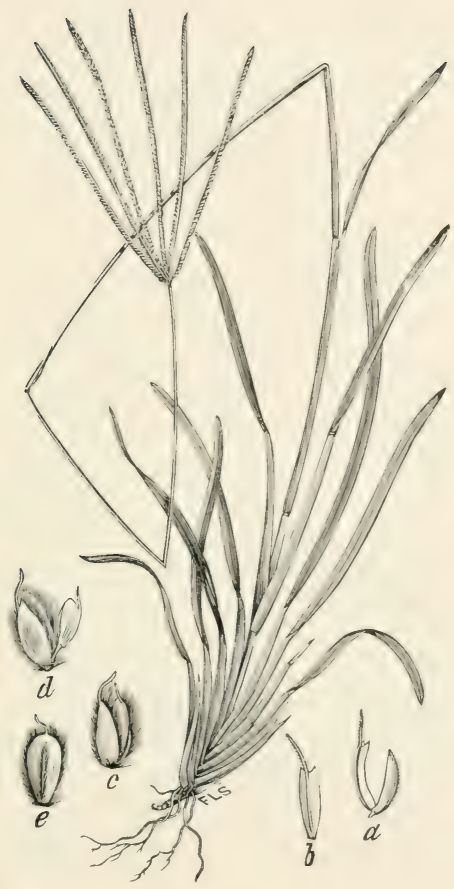

FIti. 181. Chloris neglecta Nash in Bull. Torr. Kot. Club, 22: 123.-A rather stout perennial if to 12 dm. high, with compressed, ylabrous culms and sheaths, flat leaves 10 to $35 \mathrm{~cm}$. long, and four to six terminal spikes $x$ to $12 \mathrm{~cm}$. lone. Closely allied to and much resembling $C$. floridana.-Low pine lamds, Florida. Hetober. 


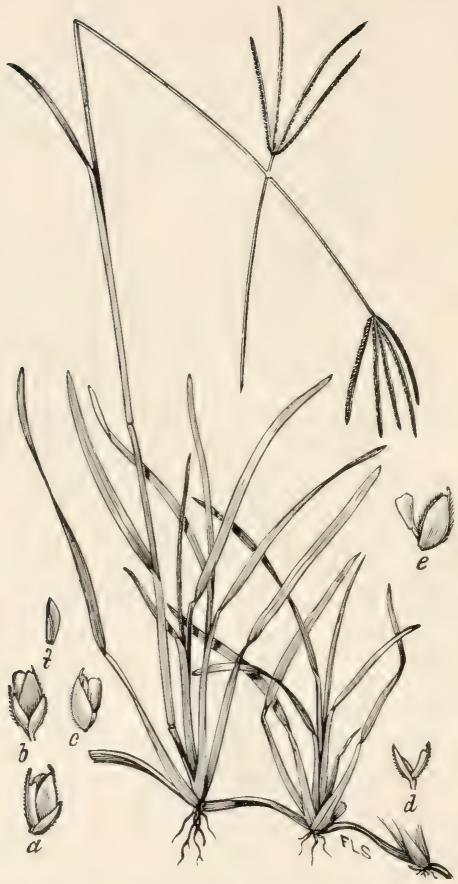

Frti. 182. Chloris petræa Sw.; Beal, Grasses N. Am., 2 : 408 (sul. C. sicarlziana Doell). Skaside Finger-Grass.-A creeping, glancous perennial 3 to $6 \mathrm{dm}$. high, with obtuse, flat leaves and three to eight slender spikes 4 to $7 \mathrm{~cm}$. Jong.-Conthern Florida to southeastern Texas. [West Indies and Central and South America.] March-October. 


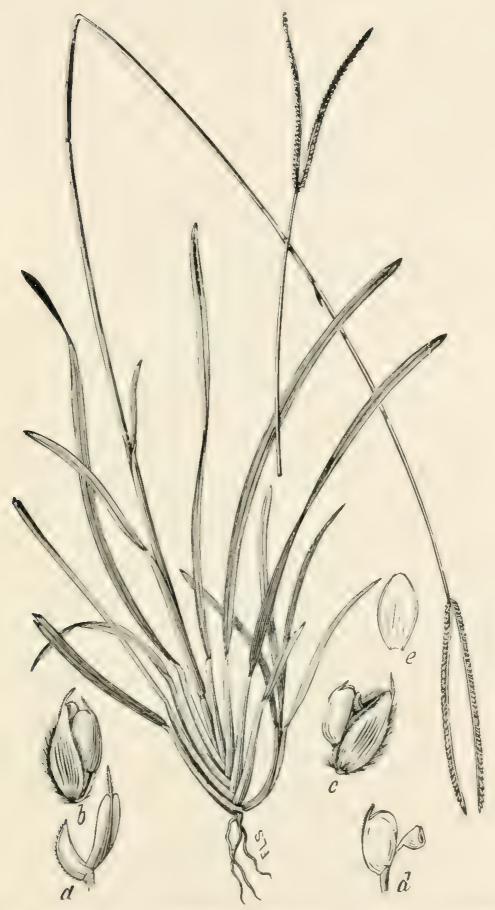

FIG. 183. Chloris floridana ('hapm.) Vasey (Eustachy.s floridunu Chajm.); lieal, (irasses N. Am., 2 : 407.-1 smooth, rither slender perenuial 3 to $6 \mathrm{dm}$. high, with compressed enlus and sheaths, flat leaves and one or two spikes $f$ to $x$ 'm. long. The spikes in this and in r', neglecta are stouter than in ('. putra.-I)ry, sandy soil, Florida. July-October. 


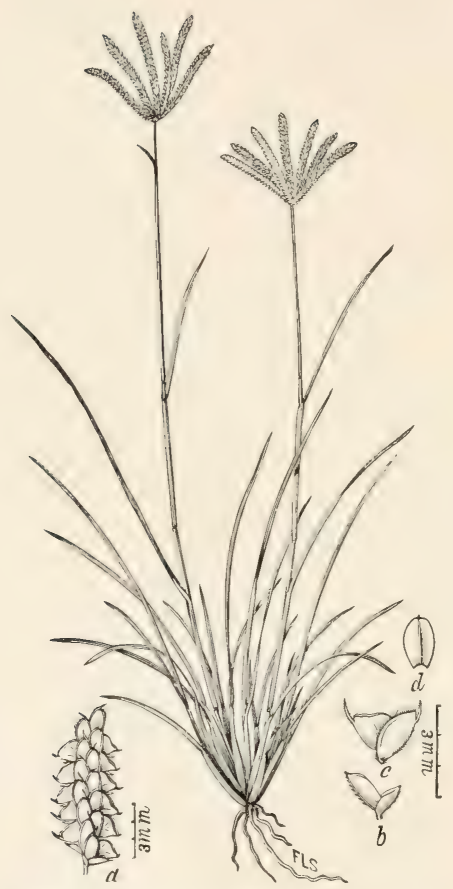

Fir. 184. Chloris cucullata Bisch.; Beal, (irasses N. Am., 2 : 407 . - A rather slender, cespitose peremnial 2 to $4 \mathrm{dm}$. high, with narrow, tlat leaves and eight to twelve spikes digitate or umbellate at the apex of the culms. Ippermost glumes eucullate.Sandy plains, Texas to Arkansas. March-September. 


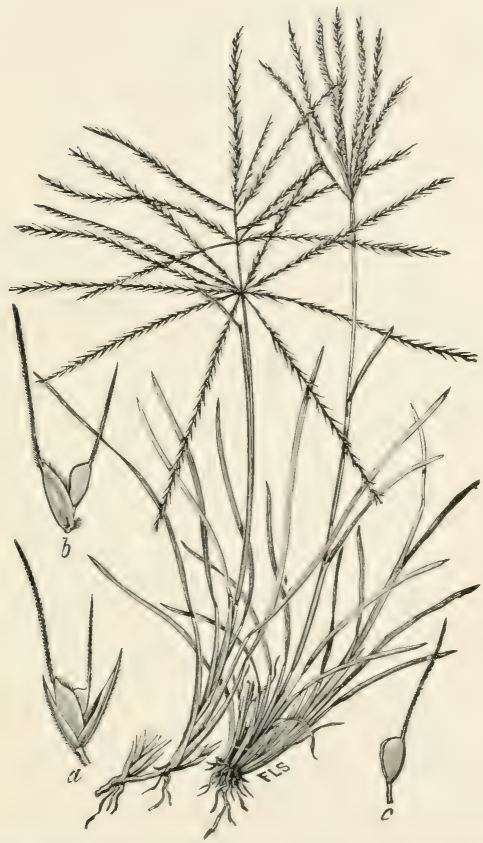

Frr. 185. Chloris verticillata Nutt. WIXDMmL-GRAss, - A low, spreading perennial, with rather stont, upright flowering branches 1.5 to $5 \mathrm{dm}$. high and numerous widely spreading. slender spikes 8 to $13 \mathrm{~cm}$. long.-I'rairies, Kansas to Texas. A good turt former. May-September. 


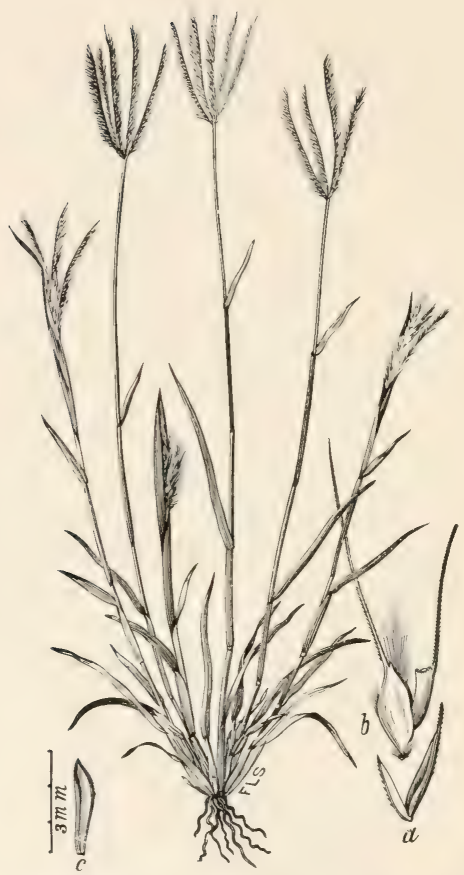

FIG. 186. Chloris elegans HBK. (C. alba Presl); Beal, Grasses N. Am., 2 : 403.-An erect perennial 3 to $6 \mathrm{dm}$. high, with slightly inflated sheaths, flat leaves and eight to twelve silky-bearded spikes, clustered or umbellate at the apex of the culms.-Dry mesas aud desert hills of western Texas, southern Arizona, New Mexico, southeru California and southward. An ornamental grass. June-November. 


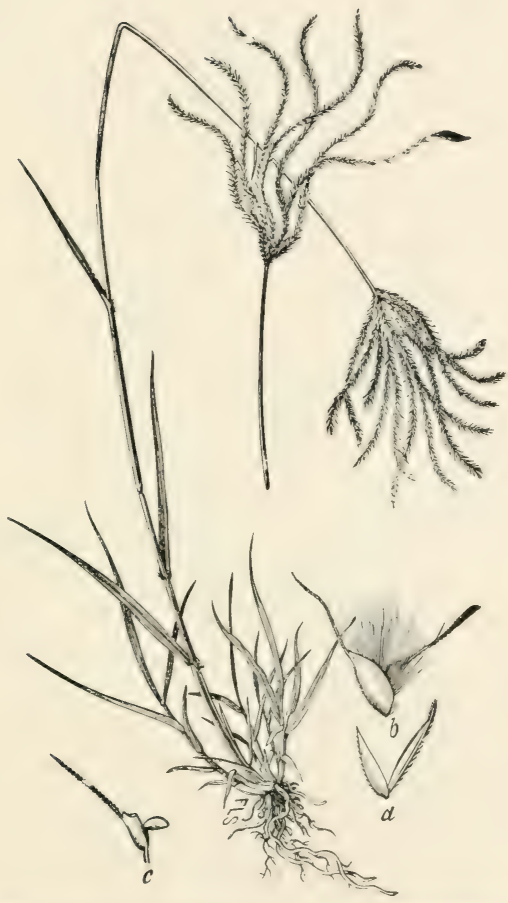

FIG. $1 \times 7$. Chloris polydactyla (L.) Sw. (.Indropoyon pulyutetylon I.). Mixy-splkin C'HLonis, - i rather stont, leafy perennial about 6 cim. high, with numerous, more or less flexnose, linwnislı spikes 8 to $13 \mathrm{~cm}$. long.-Florila. [West Indies and south America.] 


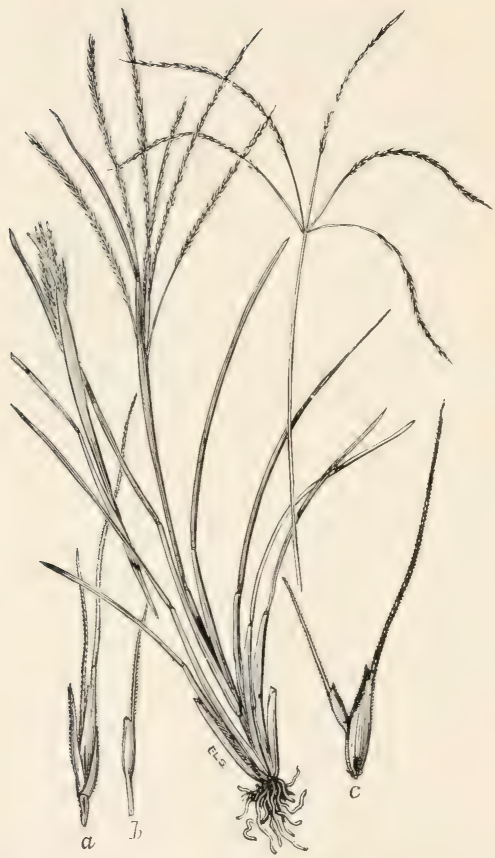

Fig. 188. Chloris texensis Nash in Bull. Torr. Bot. Club, 23: 151.-A smooth, glaucous peremial 3 to $6 \mathrm{dm}$. high, the crowded lower sheaths compressed, with that leaves and five to eight slender, terminal, digitate spikes 10 to $18 \mathrm{~cm}$. long.-Texas. [Mexico?.] 


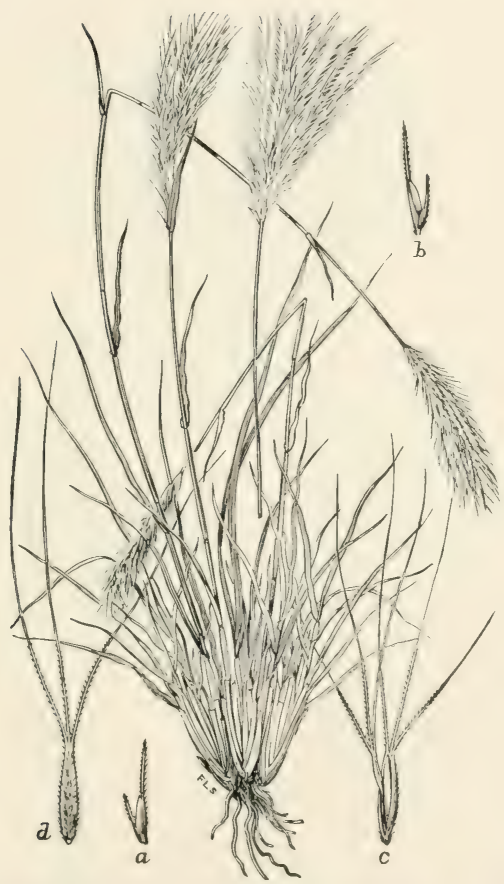

FIf. 189. Trichloris blanchardiana serihn. ( $T$. fasciculata Fourn.).-A rather stout perennial 5 to 10 (hu, high, with long, narrow leaves and many, slencler, hearded spikes, which are fasciculate or subdigitate at the apex of the culm.-Dry plains and mesas, Texas to Arizona. May-September. 


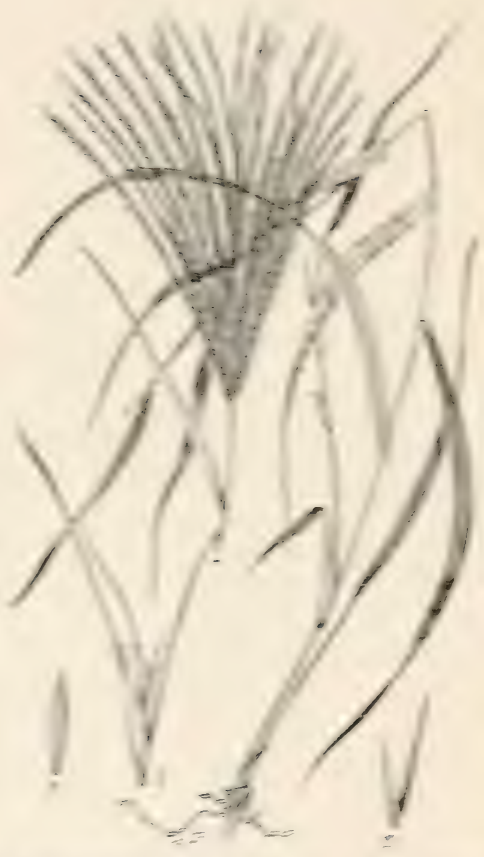

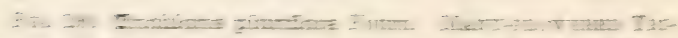

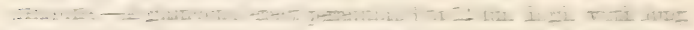

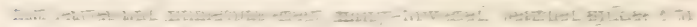

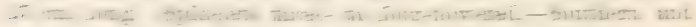

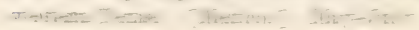




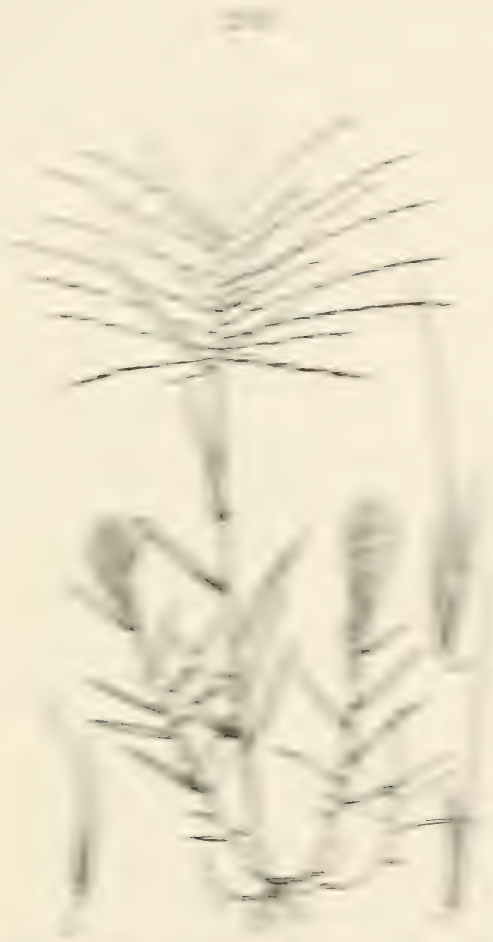

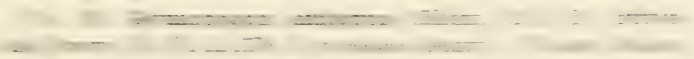

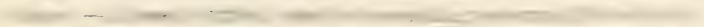

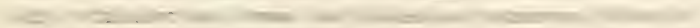
-

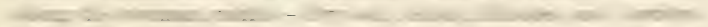

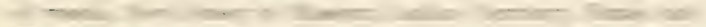
and

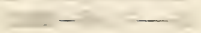




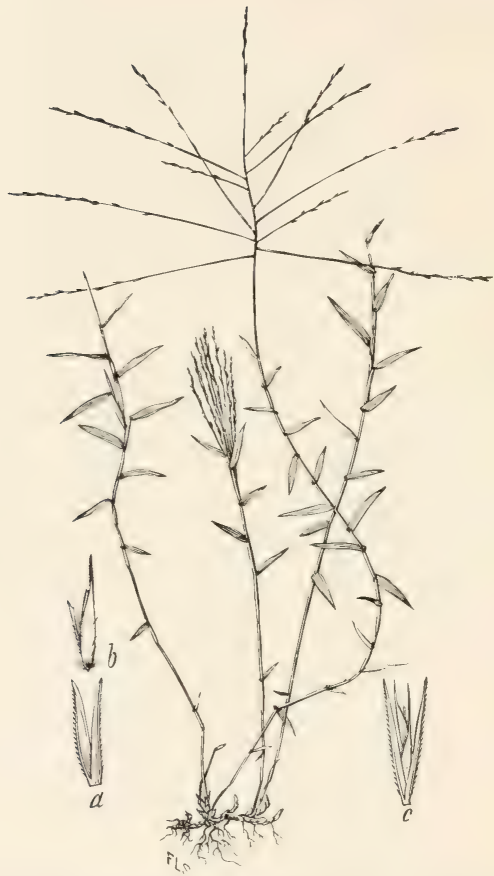

Fit. 192. Gymnopogon brevifolius Trin. SHort-LeAFED BEARD-GRAsis.-A slender, loosely tufted and many-jointed perennial, with erect or asceuding culms 3 to $6 \mathrm{dm}$. high, short, flat leaves and numerous very slender spikes, which are naked toward the base.-Dry or moist pine harreus near the coast, New Jersey to Mississippi. August-November. 


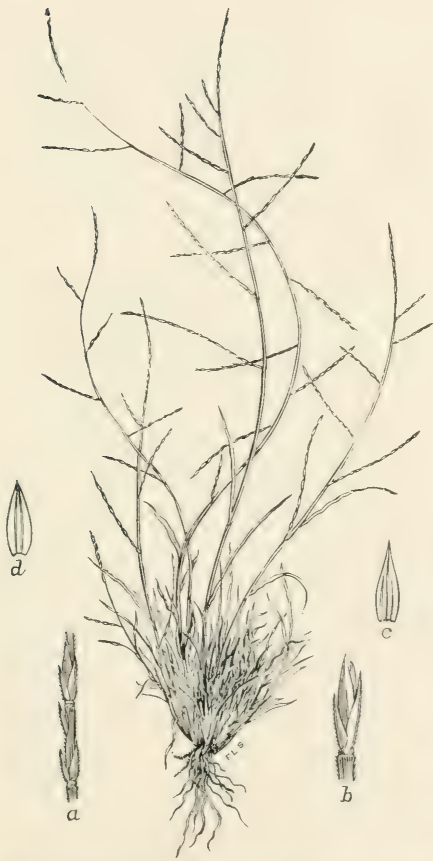

Err. 193. Schedomnardus paniculatus (Nutt.) Trelıase; 13ritton and Brown, Ill. El., I : 179 (S. Iexumus Steud.). Trxix Crab(iksss-A low, diffusely branching anmual, with short, narrow leaves and slender, panieulatespikes. The tufted stems vary from 1 to $9 \mathrm{dm}$. long.-Dry prairies. Illinois to Texas and New Mexico, north to Assiniboia and Manitoba. April-October. 


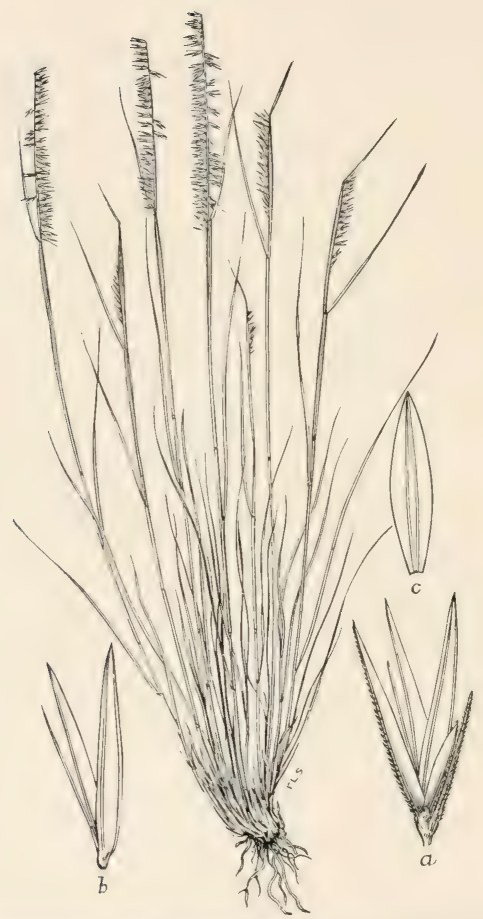

Fig. 194. Bouteloua uniflora Vasey; Beal, Grasses N. Am., 2 ; 426. ONE-FLOWERED GRAMA.-A slender, erect perenuial 3 to 4.5 dm. high, with narrow, long-attenuate-pointed leaves and numer ous (twenty-five to seventy-five), spreading or deflexed one-flowered spikes approximate along the common axis.-Southwestern Texas. September. 


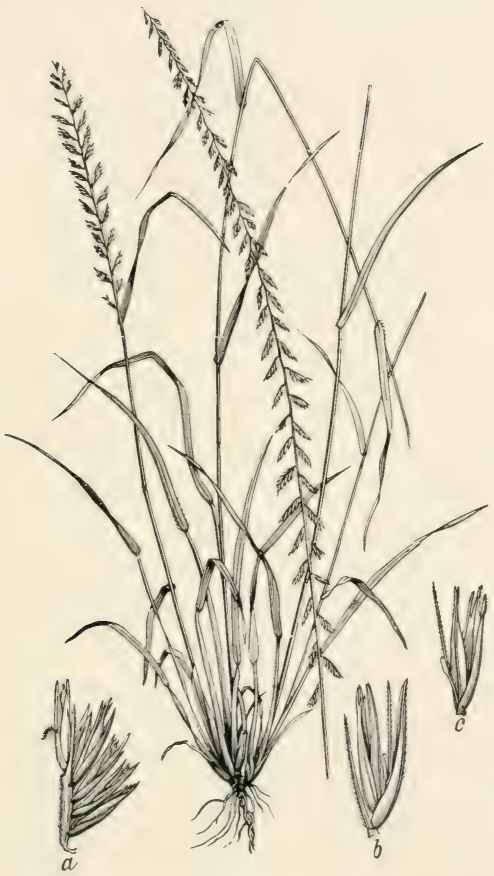

FItr. 195. Bouteloua curtipendula (Michx.) Torr. (I), racemosa Iag.). Talr, (trind or Side ()aTs.-A ileusely tufted perennial 3 to $9 \mathrm{dm}$. high, with numerous (twenty to sixty), usually spreading or reflexerl spikessiatternal along the common axis, forming a long, somewhat one-sided raceme 20 to $40 \mathrm{~cm}$. long.-Dry fields, hillsides, and prairies. New York and Ontario to New Jersey. Mississippi, Texas, ('alifornia, and Manitoba. [Mexieo and Central and South America.] May-October. 


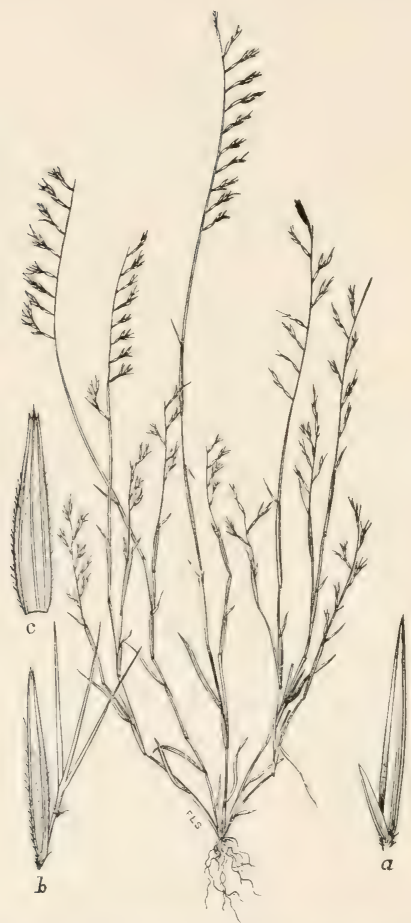

Fig. 196. Bouteloua aristidoides Thurb.; Beal, (irasses N. Am.,

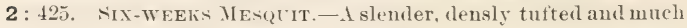
hranched anmual (?) 1 to $3.5 \mathrm{dm}$. high, with short, narrow leaves, and three to twelve very narrow and few-(sometimes only one-) flowered spikes.-Texas to southern California. [Mexico and Lower California.] August, September. 


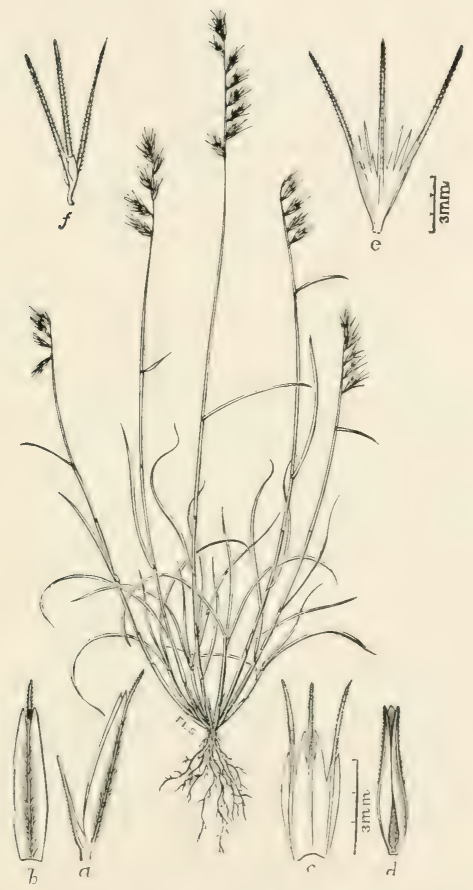

Fit. 197. Bouteloua texana S. Wats.; Beal, Grasses X. Am., 2: 426. Trxax (isiua. - A densely carpitose, nsually glabrous perennial 2 to 3 dm. high, with narrow, hat leaves, and two to ten short, many awned spilies, approximate on the emmon rachis.Dry soil, Texas and Inlian Territory to Arkansas. Mareh, April. 


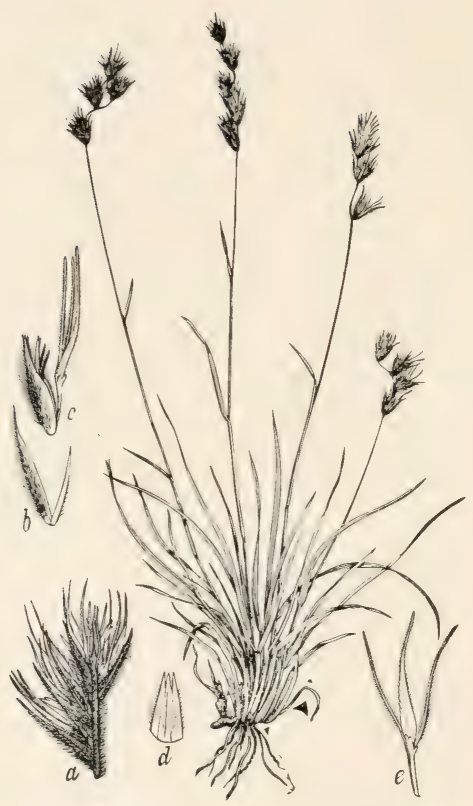

Fig. 198. Bouteloua havardi Vaseș; Beal, Grasses N. Am. 2 : 124. HAvirD's GrAuA.-A perenuial, with strong rhizomes, upright culms 2 to 4 dm. high, and four to six short, silky-rillous spikes approximate on the common rachis.-Sandy plains, rocky hills, canyons, alont springs, etc., Texas to Arizona. [Northern Mexico.] April-September. 


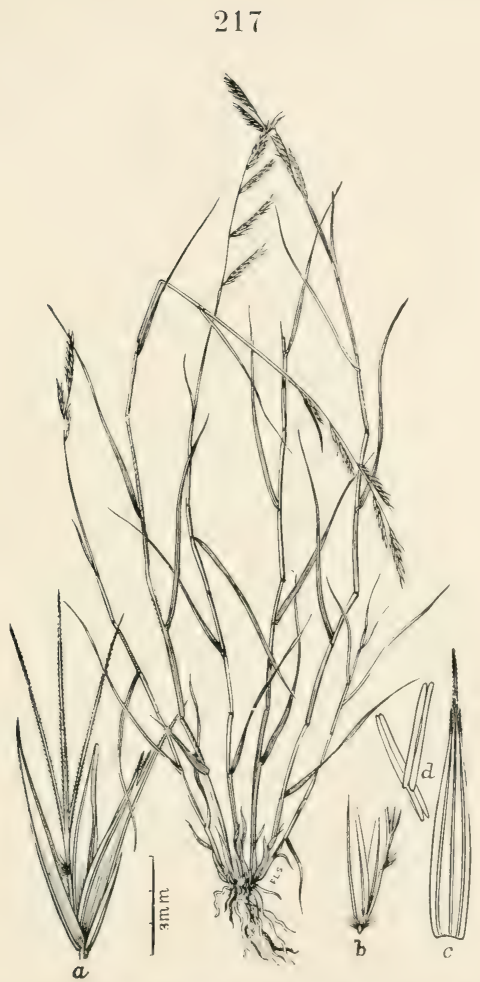

Fr. 199. Bouteloua eriopoda Torr.; Beal, (irasses N. Am., 2 :

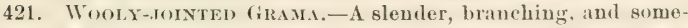
what wiry perennial with wooly-jointed stems 2 to $3.5 \mathrm{dm}$. long, with theo to six slender, spreading, and rather loosely flowered spikes 1.5 to $2.5 \mathrm{~cm}$. long.-1)ry, gravelly soil, Texas to Arizona. [Northern Mexico.] August, September. 


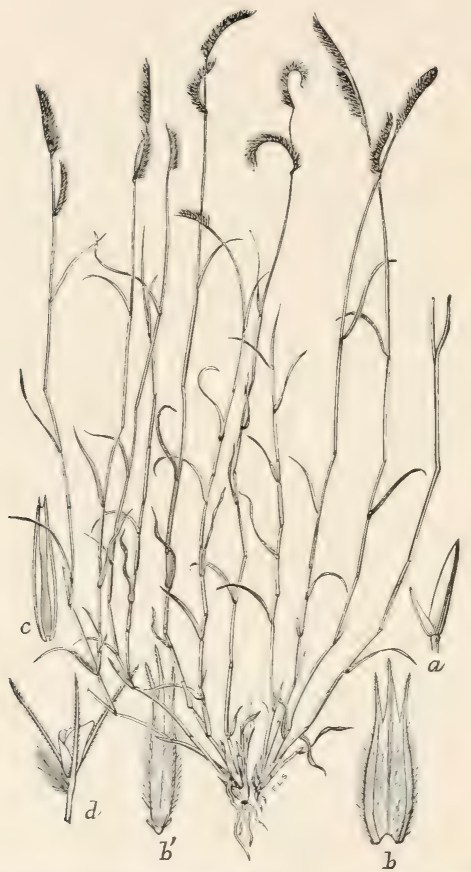

Fri, 200. Bouteloua ramosa sicribu.: Vasey, Grasses of the S. W., 1:44. WIRY GrAMA.-An erect or ascending perennial, with hranching and many-jointed culms 3 to 4.5 dm. high, short, narrow, sprearling leaves, and one to three spreading aud more or less areuate spikes 1 to 3 ('m. long.-In eanyons, momntaius of sonthwestern Texas. [Northeru Mexico.] August, Sejtember. 


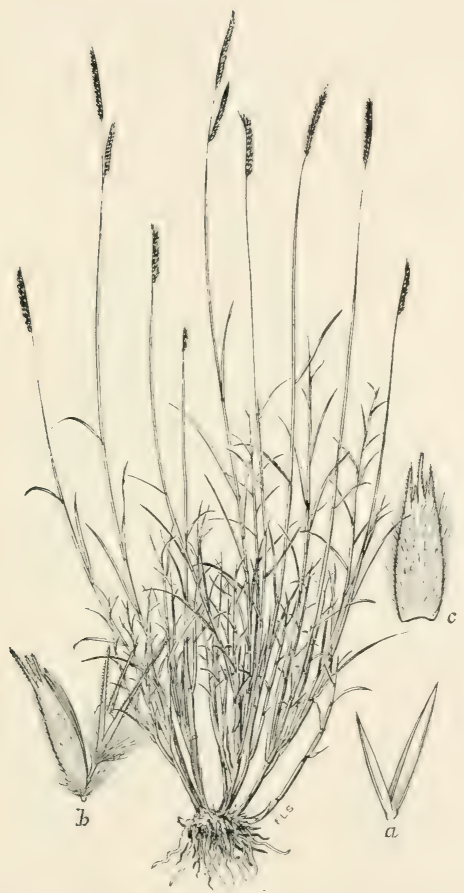

F11. 201. Bouteloua breviseta Vasey; Beal, (irasses X. Am., 2: 420. Short-Awred (imana.-In ereet, somewlat wiry and densely cirspitose premuial 2..5 to 3..5 dm. high, the lower intexnodes covered with a thin white bloom. Leaves very narmw, 2 to 4 'm. long. Silies one to threw, arect or somewhat divergent, about $2 \mathrm{cu}$. long. - Southwestern T'exas. September. 


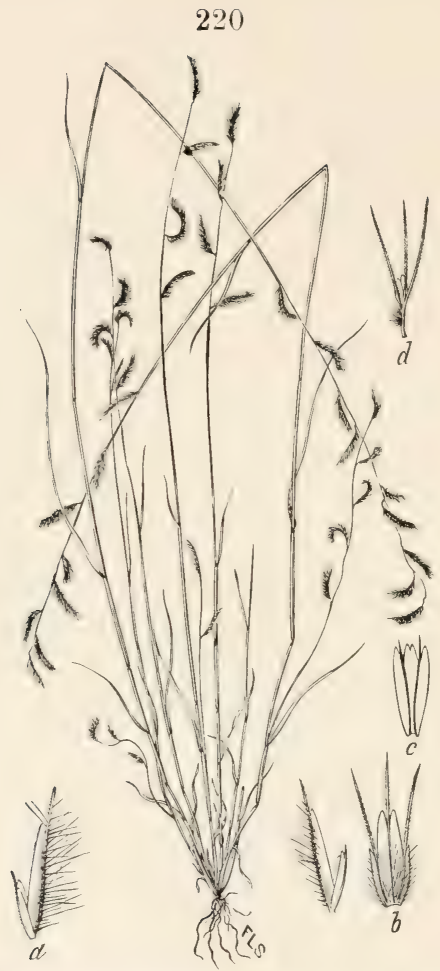

Fig. 202. Bouteloua vestita (S. Wats.) Serilın.; Beal, Grasses N. Am., 2: 419. HaIrY Grama.-A tufted annual, with ereet or ascending slender culms 3 to $6 \mathrm{~cm}$. high, with short, flat leaves and two to eight ascending, many-flowered, hairy spikes about 2 cm. long.-Sandy banks of streams and "benches" on mountain silles, western Texas to southern Arizona. [Mexico.] September, October. 


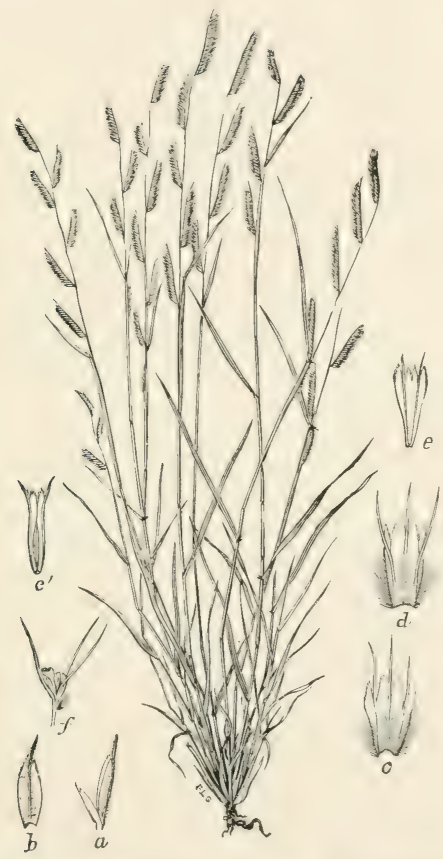

Fici, 203. Bouteloua rothrockii Vasey. Rotmlock's frian.A densely cirspitose peremial, with erect, simple or sparingly branched leafy culms 1.5 to $2 \mathrm{dm}$. high, and tivo to nine more or less spreading, densely flowered spikes 2 to $3 \mathrm{~cm}$. $10 n$. - Sandy plains, mesas and foothills, Irizona. [Mexico.] Iugust, sieptember. 


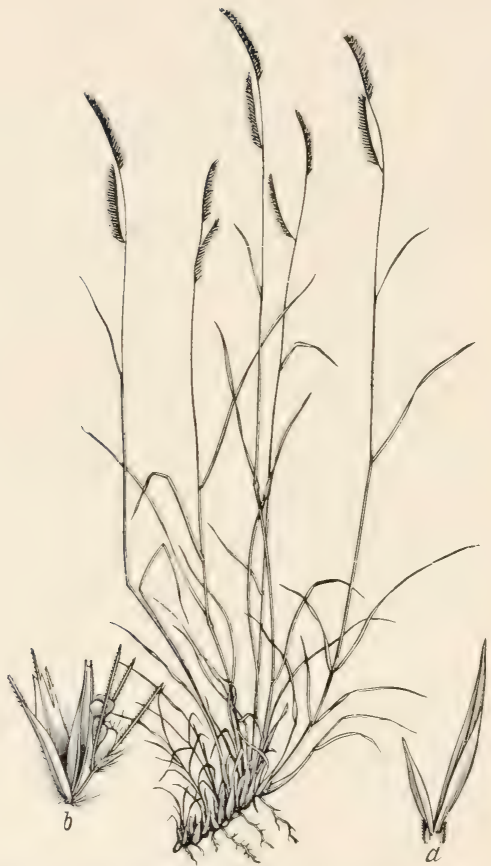

FIt: 201. Bouteloua oligostachya (Nutt.) Torr. BLtr Grum.-A slemiler peremial 1.5 to $5 \mathrm{dm}$. high, with one to five remote, pectinately many-flowered, usually spreading spikes 2.5 to $5 \mathrm{~cm}$. long. - Wisconsin to Montana, north to Manitoba anol Alberta, south to Texas, Arizona, and southern California; also at Tampa, Fla. [Mexico.] June-October. 


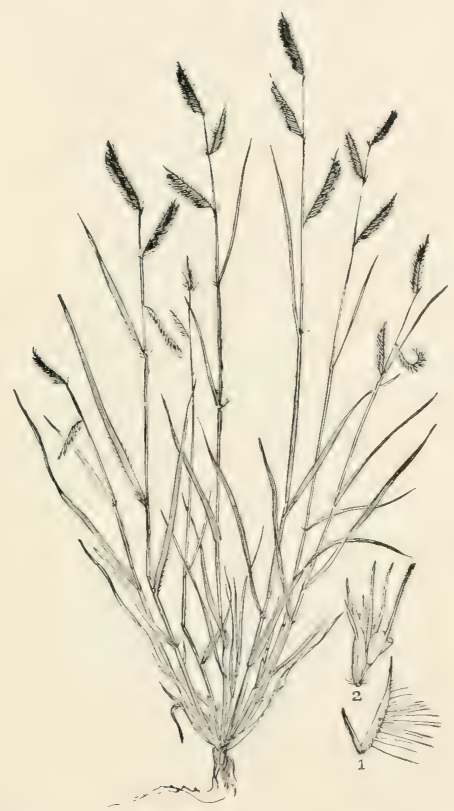

Fif. 20. Bouteloua hirsuta (IIBK.) Lag. Bristly MEsQuit.-A caspitose perennial 1.5 to 4 dm. high, with erect or ascending culns, that leaves, aud one to three more or less spreading, densely llowered spikes 2 to $4 \mathrm{~cm}$. long.-1)ry prairies and sandy plains, Illinois and Wiseonsin to Sonth lotkota, Nevada, Arizona, and Texas, and (?) sonthern Florida. [Mexiroand Lower California.] July-September. 


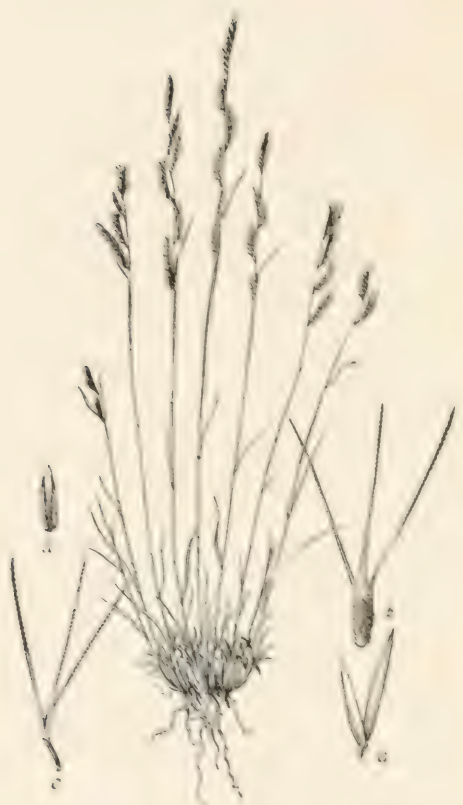

Fu, :hi. Bonteloua trifida Thurl, : henl, limssess X. Am., 2 :

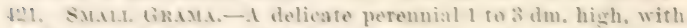

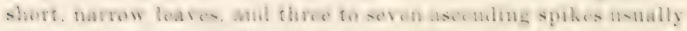
ahout 2- em. long.-Mesas am samey plains, Texas to Irizona. [Northern Mexieo.] May-()etoher. 


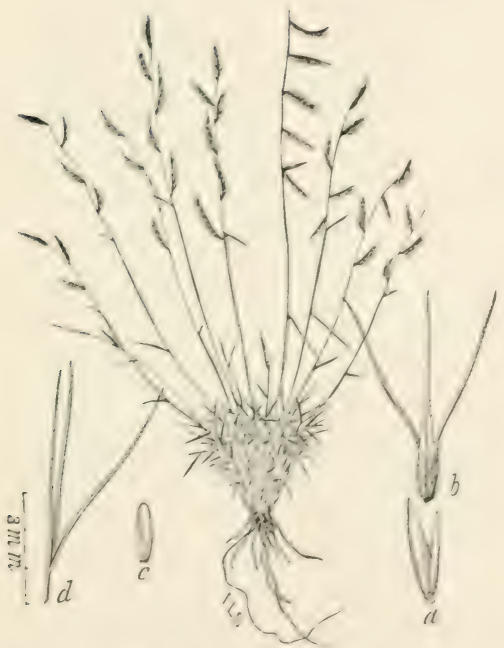

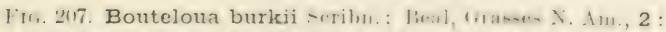

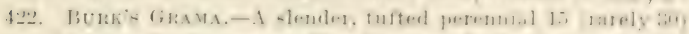

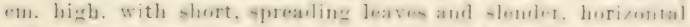

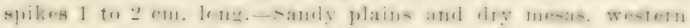
Texas. [Northern Mexico.] April-,Inly.

$$
11162-\text { No. } 7-15
$$




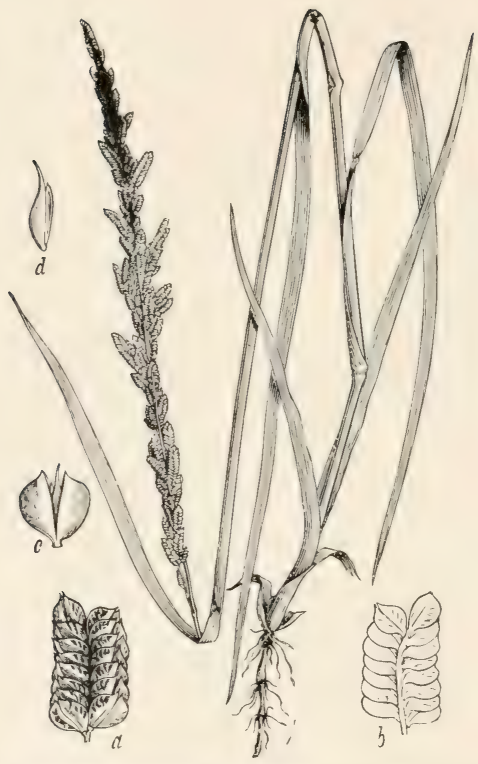

FIf. 208. Beckmannia erucæermis (L.) Hust (Ihuluris eructformis Linn.). Flowill-(iRAs-. I stont, erect, subaquatic perennial 3 to 12 dm. high, with narrow panicles composed of many, densely flowered one-sided spikes.-In sloughs and aloug the hauks of rivers and streams, western Ontario to Iowa, ('alifornia, British Columbia, and Alaska. [Europe and Asia.] June-September. 


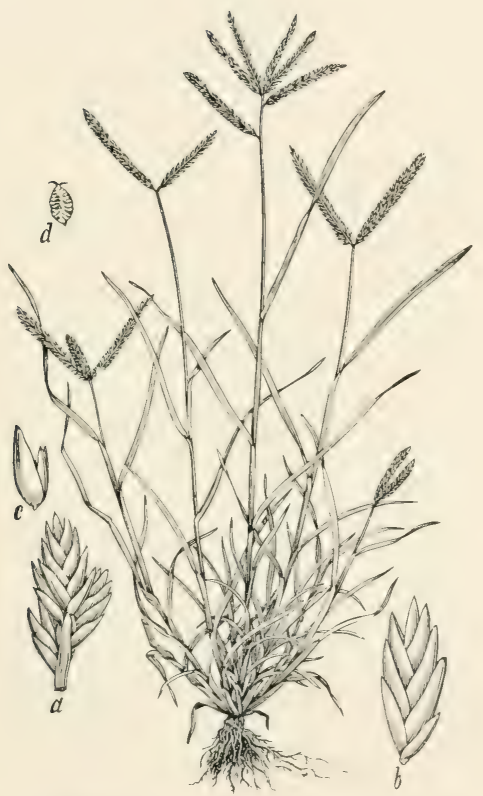

Fıc. 209. Eleusine indica (L.) Gaertn. Goose or Yard(irass.-A coarse, tufted anmal, with erect or spreading stems 1.5 to $6 \mathrm{dm}$. high, and two to five digitate spikes is to $7 \mathrm{~cm}$. long.Waste or enltivated ground, Now Jersey to Ohio and hansas, sonth to Florida and Texas. [Widely distributed in tropieal and subtropical countries.] June-October. 


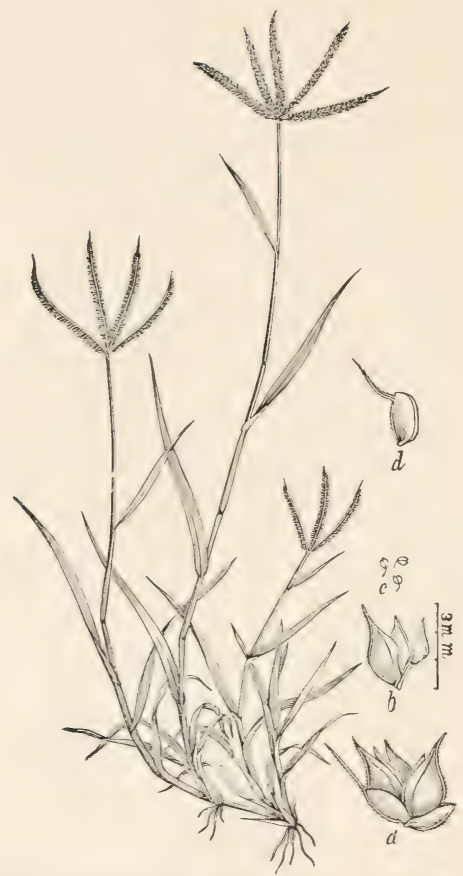

FIf. 210. Dactyloctenium ægyptium (L.) Willd. (Cynosurus agyptius L.; Dactyloctenium ayyptiacum Willl.). Crowfoot(iliss.-1 low, tufted or creeping grass, with ascending flowering stems rarely $3 \mathrm{dm}$. high, and three to five digitate spikes 2 to $5 \mathrm{~cm}$. long. - Waste or cultivated grouml, southern New York to Illinois, south to Florida and Texas, west to C'alifornia. [Widely distributed in tropical and subtropical regions of both hemispheres.] May-December. 

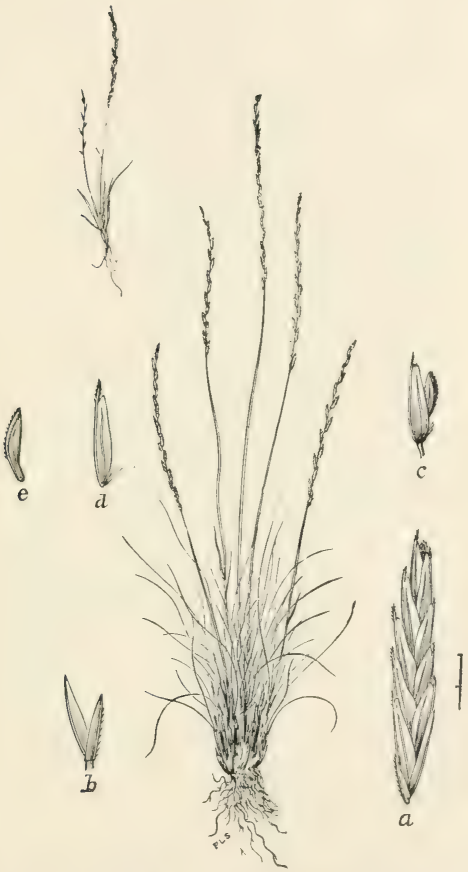

Fir. 211. Leptochloa spicata (Nees) Acribn. (Lromus spicatus Nees; Diplachne spicata Doell; D. reverchoni Vasey); Beal, Grasses N. Am, 2: 434.-1 low, densely cirspitose perennial (?), with numerous setaceous hasal leaves and a slender, seape-like culm 6 to $15 \mathrm{~cm}$. high.-Granitie rocks, central Texas. [Mexico and Brazil.] May-July. 


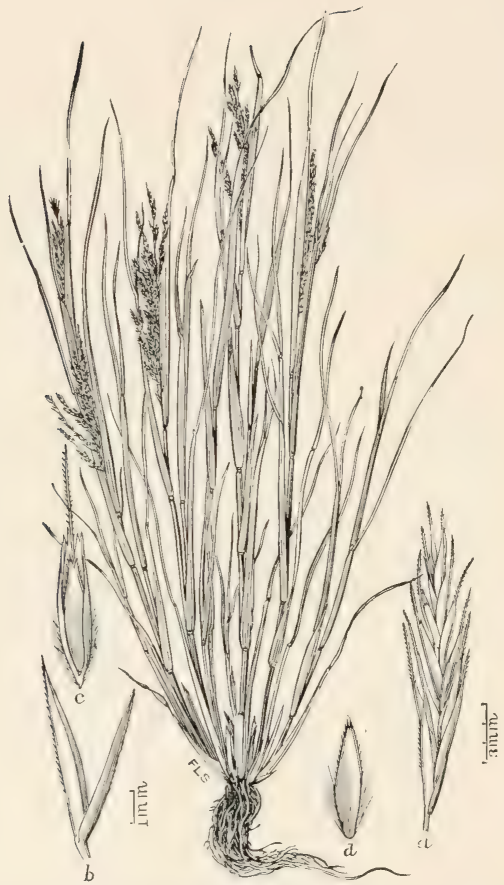

Fig. 212. Leptochloa fascicularis (Lam.) A. Gray. ClusTERED SALT-GRASS.-An erect, ascentling or more or less diffusely sprearling, ciespitose, much-hraucher annual 5 to $6 \mathrm{dm}$. high, with numerous, erect, crowded spikes 6 to $x \mathrm{~cm}$. long.- Salt marshes aloug the coast, Rbode Island to Texas; saline soil in the interior, western New York to South Dakota, Nevada, New Mexico, and Texas. [Mexico and West Indies.] July-September. 


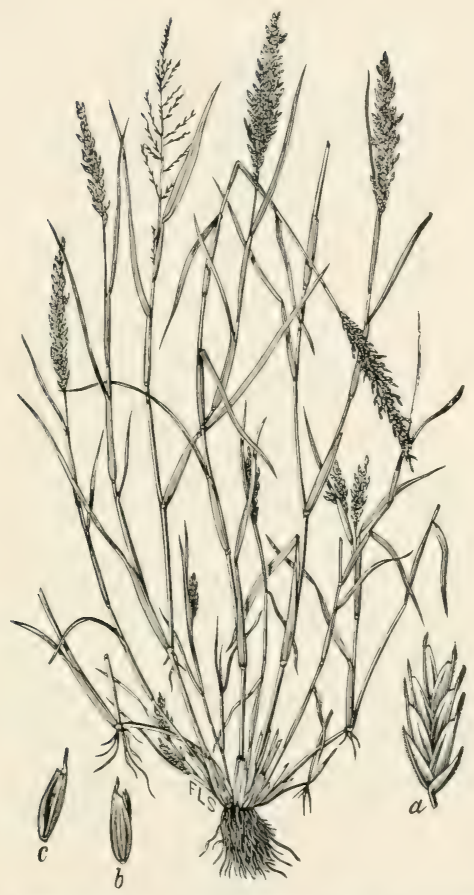

FIG. 213. Leptochloa viscida (Seribn.) Beal (Diplachne visrida S.ribn.). VIscin Lertochloג, - I densely cirspitose and ditfusely branched perennial (?) 0.5 to .3 (rarely 6 ) dm. high, with acute, flat leaves, and narrow, densely tlowered panicles, composed of eight to twelve erect spikes.--Wet, clayey soil, New Mexico and Arizona. [Mexico and Lower ('alifornia.] June-september. 


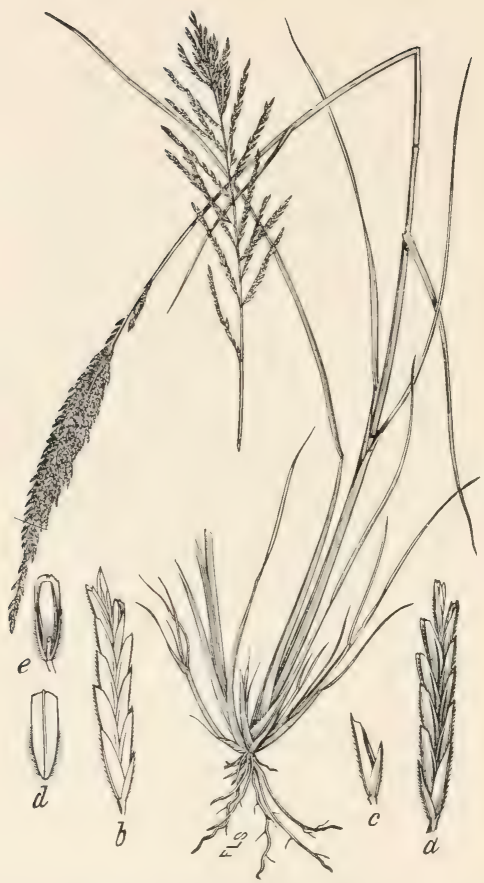

FIG. 214. Leptochloa imbricata Thurb. (Diplachne imbricata Sicrihn.); Beal, Grasses N. Am., 2 : 435. - A rather stont, erect or asceurling pereunial 3 to $9 \mathrm{~cm}$. high, with smooth, usually glaucous culms, narrow, flat leaves, and numerons crowded, erect or ascending spikes 4 to $6 \mathrm{~cm}$. long.-Texas to sonthern California. [Mexico and Lower California.] August-November. 


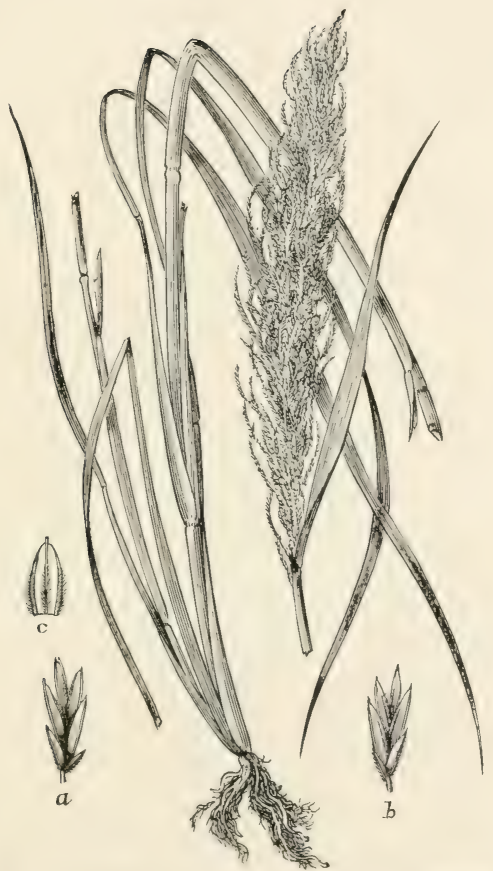

Fig. 215. Leptochloa scabra Nees (L. langloisii Vasey). RoviII LeptocnLoA.-A stout anmal if to $12 \mathrm{dm}$. high, with flat leaves and very many, crowhed, slender spikes in terminal panicles 3 dm. long.-Ditehes and fields, I. onisiana. [Brazil.] September. 


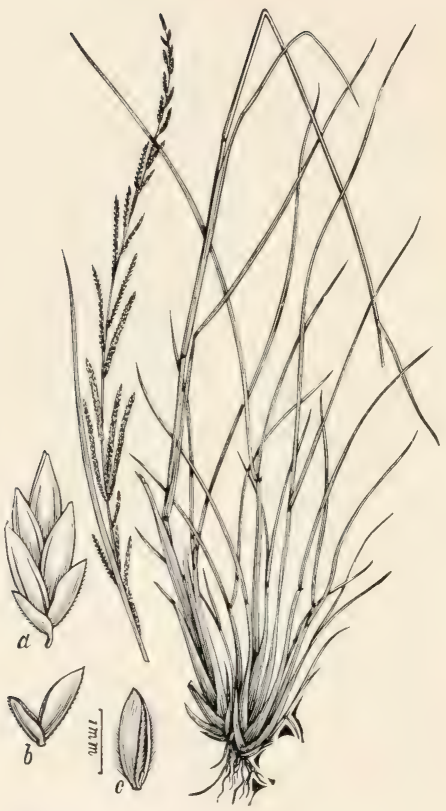

FIG. 216. Leptochloa nealleyi Vasey (L. stricta Fourn.). NeaLLEY's LFPTOCHLOA.-A slender, or rather stont perennial, with erect or ascending culms 4.5 to $12 \mathrm{dm}$. high, and narrow, elongated panicles of many erect or ascending spikes.-Western Texas. [Mexico.] April-June. 


\section{5}

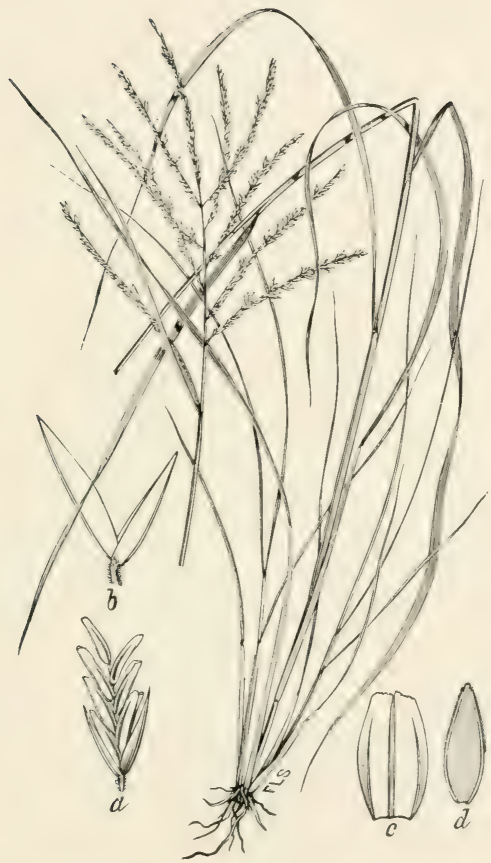

F1t: 217. Leptochloa dubia (HBK.) Nees (('hloris dubia HBK.; Diplachue dubia Seril,n.); Beal, Grasses N. Am., 2: 437.-A rather stout and apparently perenuial species, 3 to $9 \mathrm{dm}$. high, with usually eight to ten approximate spreading spikes $f$ to $8 \mathrm{~cm}$. long. - Southern Florida, Texas to Arizona, and southward into Mexico. April-September. 


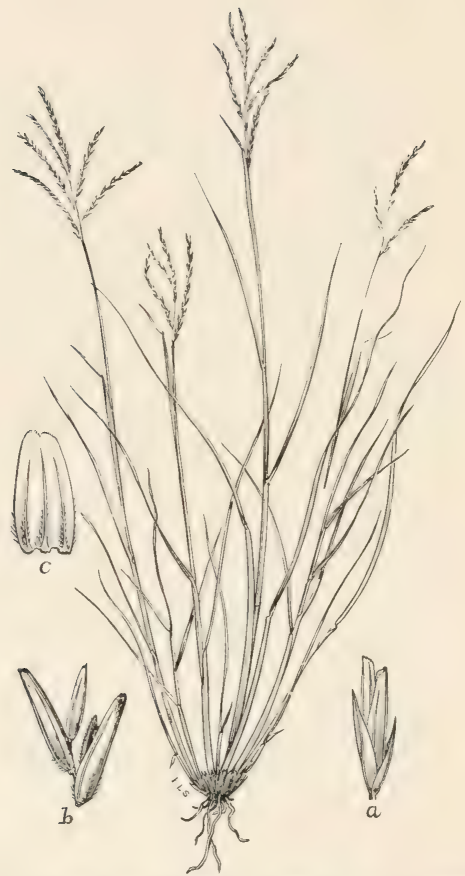

FIG. 218. Leptochloa pringlei (Vasey) Beal, Grasses N. Am., 2: 436.-A rather slender perennial 2.5 to $3.5 \mathrm{dm}$. high, with narrow leaves and four to six spikes 2.5 to $5 \mathrm{~cm}$. long, apıroximate near the summit of the eulm. Spikelets two- to threeflowered.-Arizona. April, May. 


\section{7}

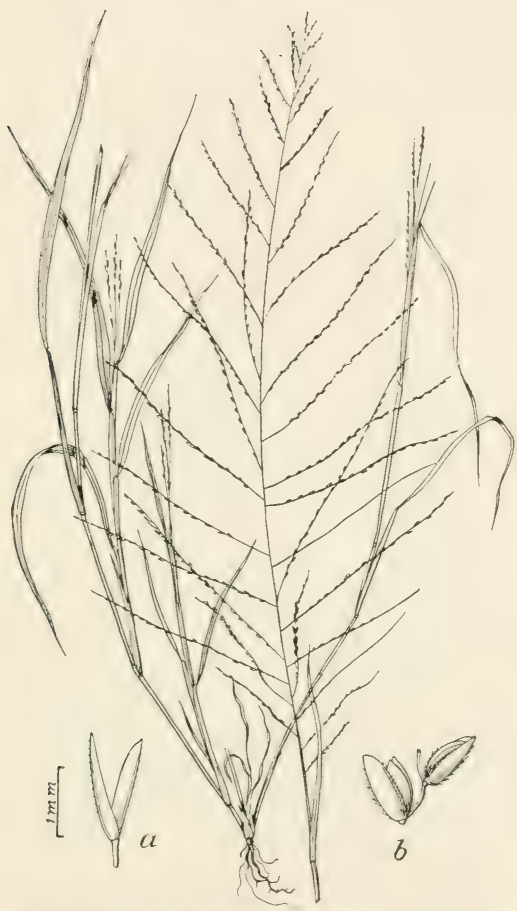

Fir, 219. Leptochloa mucronata (Michx,) Kunth. FEATuErGRAss, - A more or less branchmy anmual 6 to 12 dm. high, with rather broad, flat leaves and long terminal panicles of many slender spikes. - A weed in cultivated and waste grounds, Virginial, Illinois, Missonri, Tennessee, Mlahama, Texas, Indian Territory, Arizonat, and California. [Northern Mexien and C'uba.] June. October. 


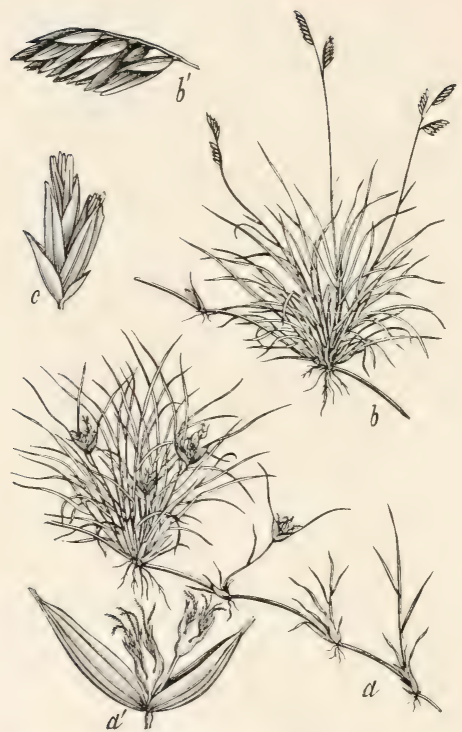

FI(r. 220. Bulbilis dactyloides (Nutt.) Raf. (Buchlö̈ dactyToides Engelm.); Britton aud Brown, Ill. Fl., 1 : 183. BuffaloGRAss.-A low, fine-leafed, and extensively creeping perennial, rarely more than 1 to $1.5 \mathrm{dm}$. high. Similar to Bermuda in habit of growth.-Dry prairies and river bottoms, Minuesota and South Dakota (ascends to $1,650 \mathrm{~m}$. in 13lack IIills), to Arkausas, southern Texas, and Colorado. [Mexico.] March-August. 


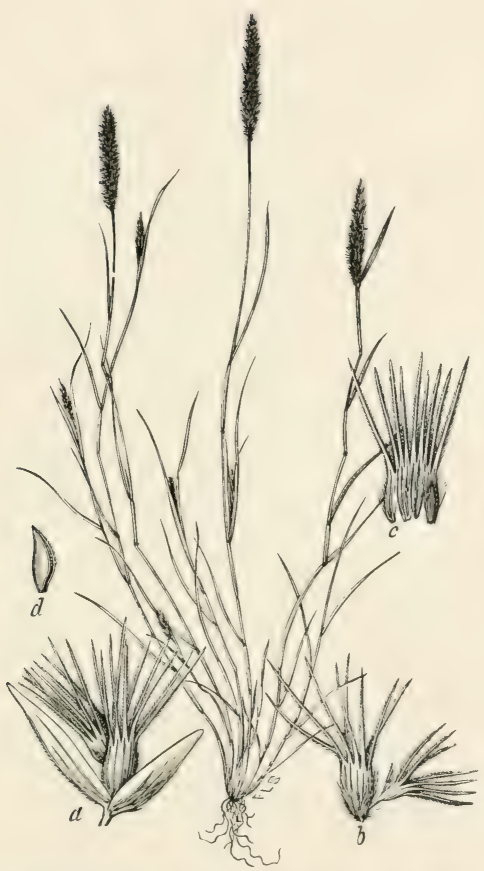

Firi, 221. Pappophorum wrightii S. Wats. (I' boreale Torr., not

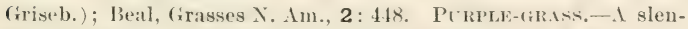
der, branching and apparently annual species 2 to 4 dm. high, with narrow, involute leaves and densely flowererl, spike-like, lead-colored or purplish panicles 1 to $7 \mathrm{~cm}$. long.-Roeky hills, canyons, and open plains, western T'exas to Arizona. [Northern Mexico.] July-September. 


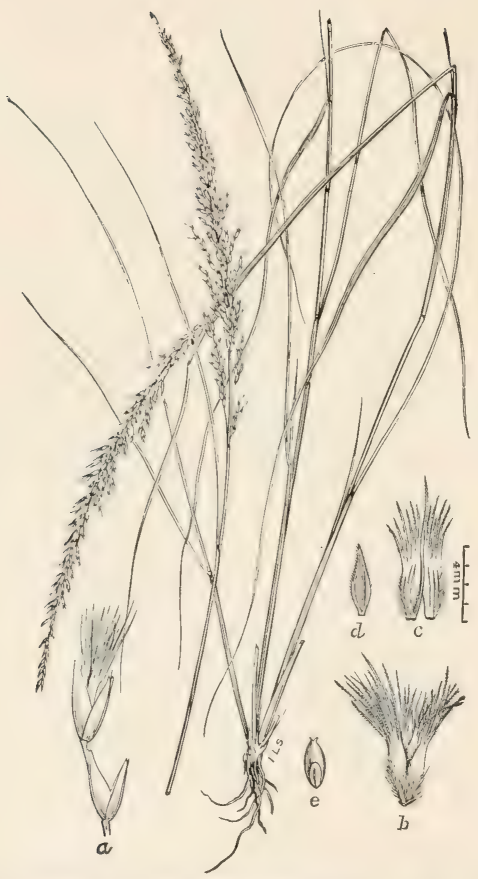

FIG. 222. Pappophorum apertum Serihn.: Bull. Torr. Bot. ('lub, 9: 148; Beal, Grasses N. Am., 2 : 447.-A cirspitose perennial : to 8 dm. high, with long, narrow, mostly involute leaves and narrow, pale, or often straw-colored pauicles 15 to $20 \mathrm{~cm}$. long.-Valleys, western T'exas to Arizona and Mexico. June. 


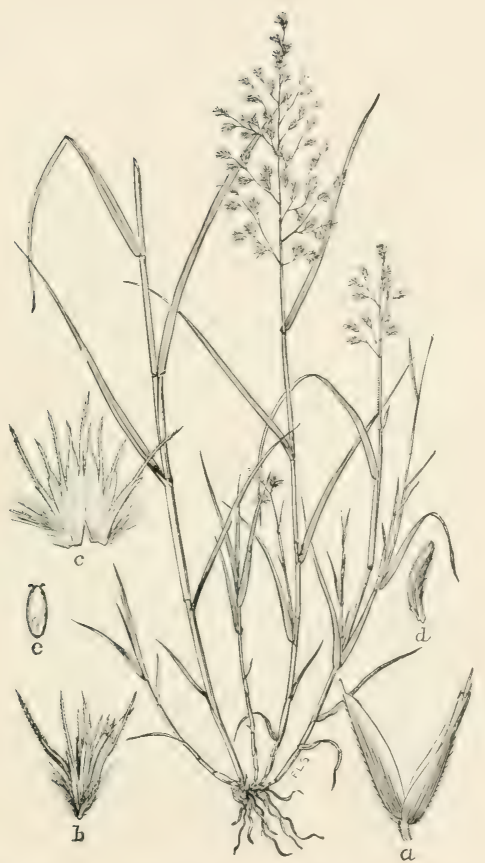

FIG. 223. Cottea pappophoroides Kith. ('otT.1-GR.1ss.-An erect, branching perennial 3 to $6 \mathrm{~lm}$. high, with narrow, llat, pilose leaves and oblong, open panicles ! to $18 \mathrm{~cm}$. long; spilielets two-to six-flowered, floral glumes many-parted.-In canyons, western Texas to Arizona. [Mexico and south America.] AugustOetober. 


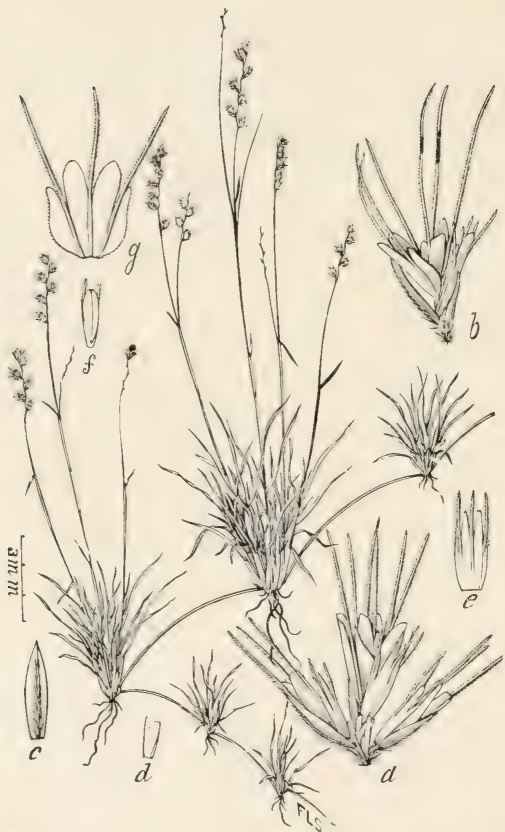

FIG. 221. Cathestecum prostratum Presl ( $C$. crertum Vasey and Hack.) ; Beal, Grasses N. Am., 2 : 452.-An extensively creeping, slender perenvial, with upright flowering branches 1 to $3 \mathrm{dm}$. high, narrow, flat leaves, and clustered spikelets in terminal or lateral racemes.-Dry mesas and bluft's along the Rio Grande western Texas. [Mexico.] July-October. 


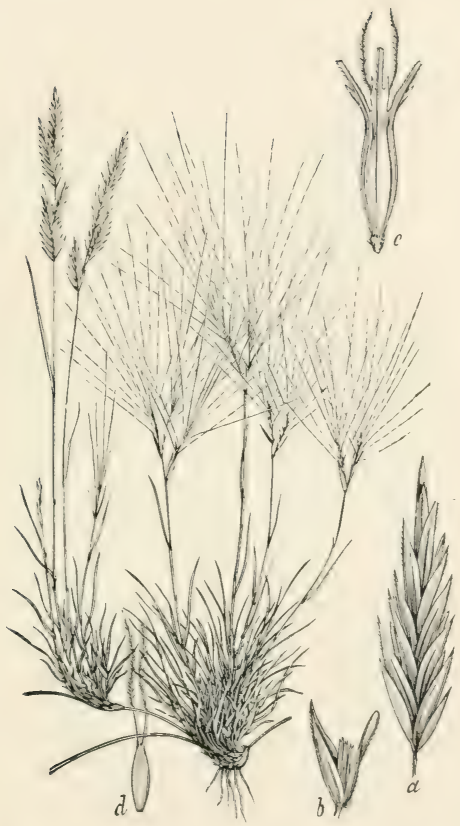

Fig. 225. Scleropogon brevifolius Philippi (Tricuspis monstrosu Mnnro; Lesourdia multiflora and L. larriusliyanu Fourn.).A wiry, creeping perennial with densely tufterl, upright, leafy branches 1 to 2.5 cm. high, and unisexnal spikelets: the pistillate long-awued, the staminate atruless.-Dry mesas and canyons, Colorado to Texas, New Mexico. Arizona, and sontloward into Mexico and South America. May-Oetoler. 


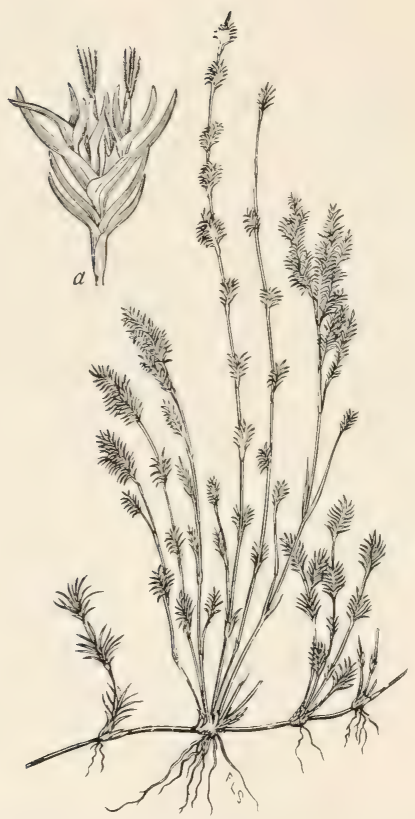

Fig. 226. Monanthochloe littoralis Engelm. SAlt CEDAR.A ereepiug grass, with hard, woody stems, and crowded, subulate, rigid leaves $2 \mathrm{~cm}$. long or less. - Rocky shores and salt marshes aloug the coast, southern Florida, extreme southern Texas, southern California. [Lower California.] May, June. 


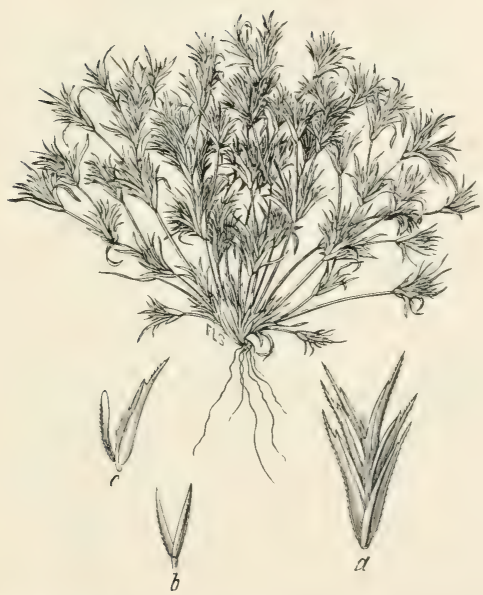

Fir, 2.27. Munroa squarrosa (Nutt.) Torr. False BuffaloGrasi- - low, diffusely much-branched anmual, with erowded and sharply pointed, rigid leaves 0.5 to $2.5 \mathrm{em}$. long.-Prairies and dry plains, South l)akota to Trxas, west to Mberta. Montana, Colorado, and Arizona. June-October. 

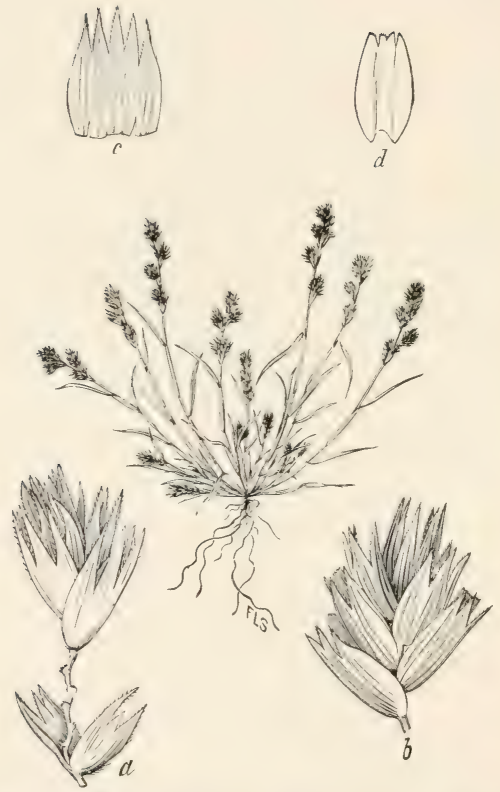

FIG. 228. Orcuttia californica Vasey: Beal. Grasses N. Im., 2: 457 . - low, much lranhed, carspitose annual 11.5 to $1 \mathrm{dm}$. high, the unmerons stems bearing three to six spilielets near the apex.-Southeru and Lower California. April. 


\section{7}

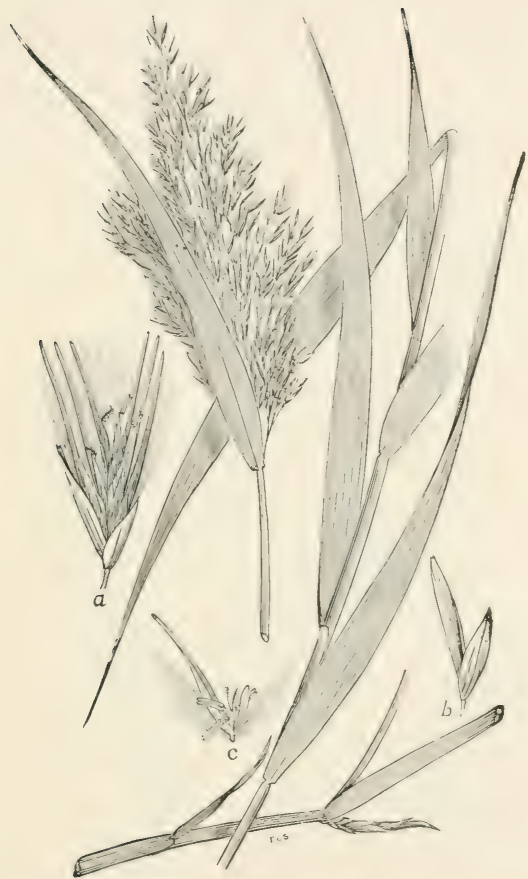

FI(i. 2:9. Phragmites vulgaris (Lam.) I. S. I'. I'. rommunis

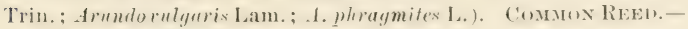
I tall, stont, perennial yrass, with stont, ereeping rootstocks, numerous hroal, attennate-pointed leaves, and a large ovoinpyamialal, purplish, terminal panirle.-Margins of lakes amel rivers and in bratkish coast marshes, almost everywhere in the Inited States and southern british Amerieas. [1Videly distributed in temperate regionsof both hemispheres.] Angust-fletober. 


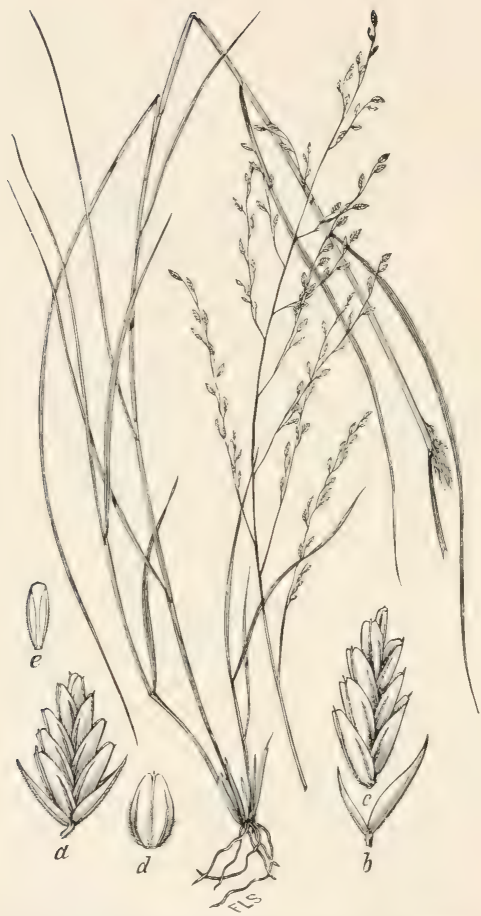

FIG. 230. Triodia eragrostoides Vasey it Scribn. (Sieglingia errgrostoides Dewey); Beal, (frasses X. Am., 2 : 465.-An erect, leafy pereanial 6 to $9 \mathrm{dm}$. high, with long, narrow leaves and open, small-flowered panicles 2 to 3 chm. long.-Roeky banks, ete., southern Texas, southern Florida. [Northeastern Mexico.] JuneOctober. 


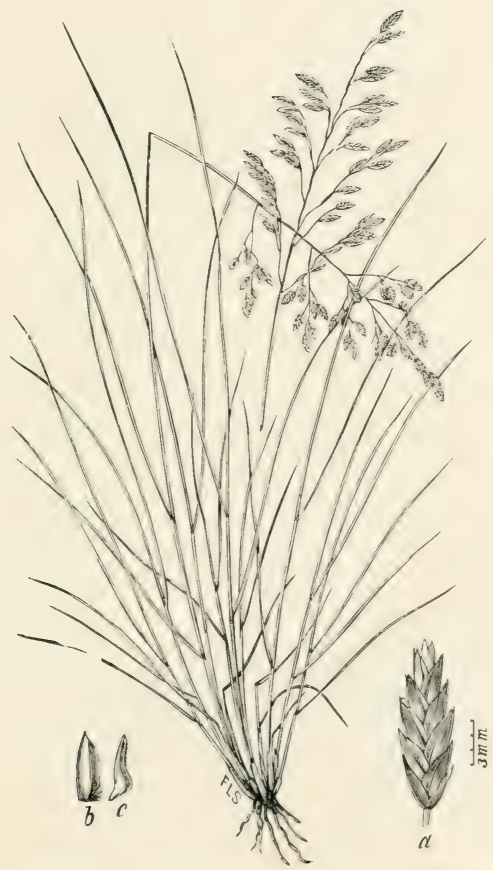

FI, 231. Triodia texana S. Wats.: Ieal, (irasses N. Am., 2 : 166. -A slenter, wiry grass 3 to fi dm. high, with very narrow leaves and loosely few-flowered, nodhling panicles 10 to $15 \mathrm{~cm}$. long.-Rich valley land, dry places, ete., lonisiana and Texas to Arizona. [Northern Mexico.] June-August. 


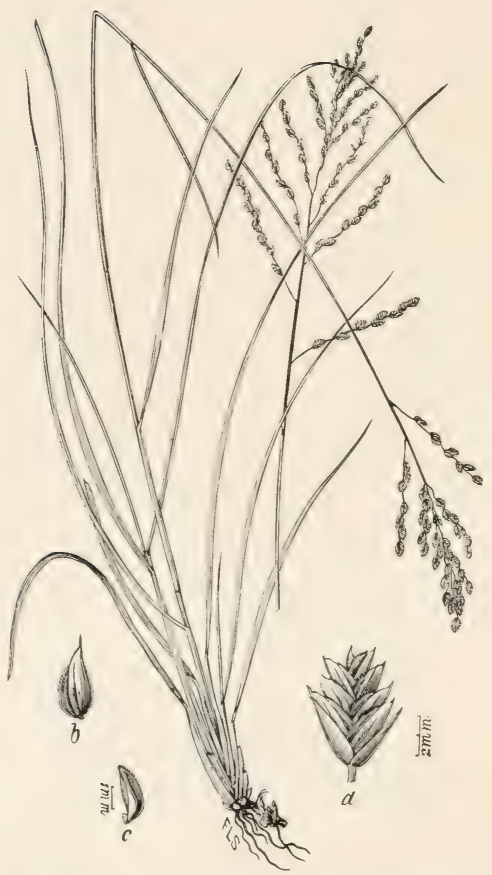

FIci. 232. Triodia ambigua (Ell.) Vasey; Beal, (irasses N. Am.. 2: 465, sub. Sieglingia (Poa ambiyna Ell.).-An erect perennial is to 12 dh. high, with narrow, tlat leaves and open, pyramidal panicles 10 to $20 \mathrm{~cm}$. long.-Dry, open, pine barrens near the coast, South Carolina to T'exas. July-October. 


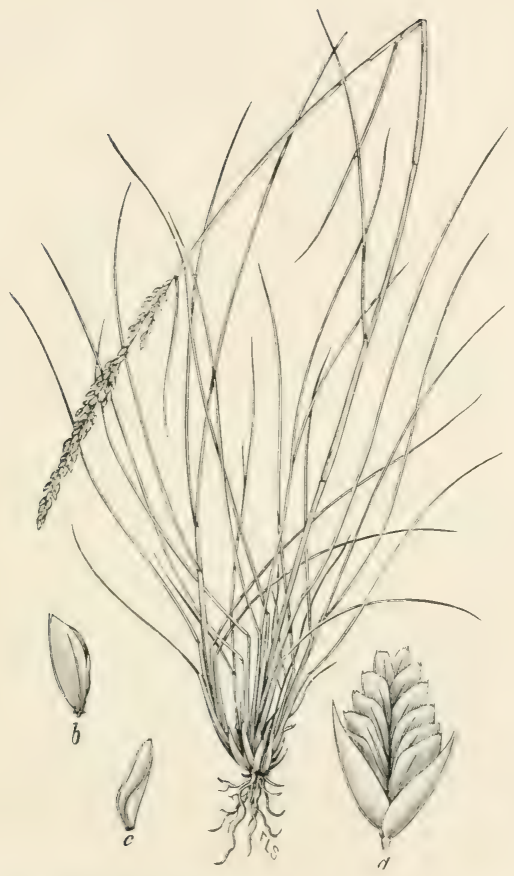

Frt. 283. Triodia albescens (.Mnnro) Vasey (. Sieglingiu albes-

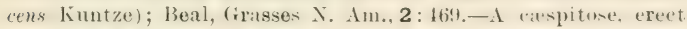
perennial I to 7 dm. high, with uarrow, flat leaves and deusely tlowered, spikw-like panicles 9 to $15 \mathrm{~cm}$. long.-Texas. AugustOctober. 


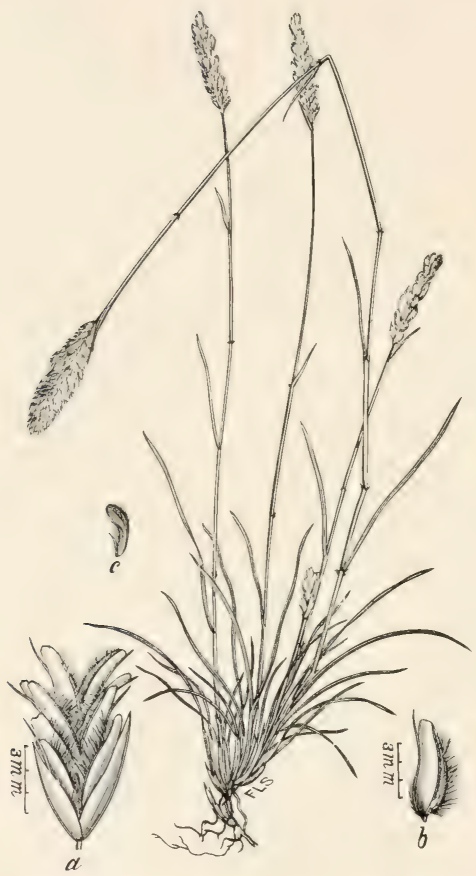

Fig. 234. Triodia nealleyi Vasey; Bull. Torr. Bot. C'lub., 15 : 49 (188x); (Sieglingia nealleyi Dewey ; Beal, Grasses X. Am., 2 : 470).A slender, glancons, ciespitose perennial, 3 to $4 \mathrm{dm}$. high, with that or conduplicate leaves, aud densely flowered, linear or ovoid panicles 4 to $5 \mathrm{~cm}$. long.-Canyons and ridges, sonthwestern Texas. September. 


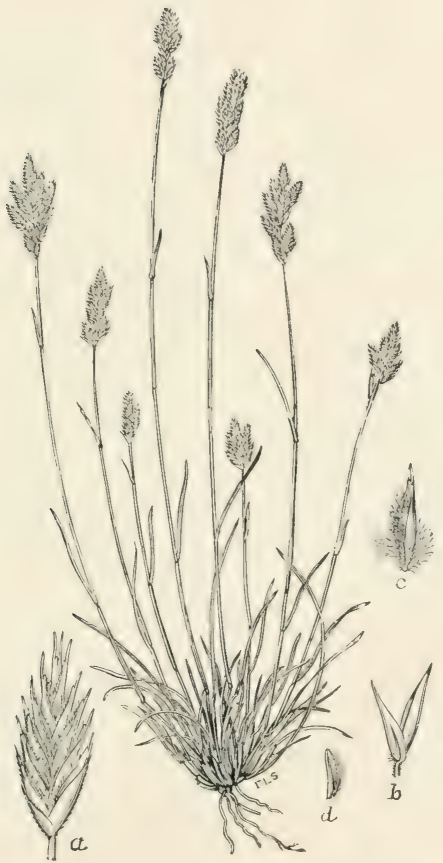

FIG. 235. Triodia acuminata (Munro) Vasey (Sirglingiu ucuminatu Kuntze); Beal, Grasses N. Am., 2 : 470.- I slender, deusely tufted peremual 1 is to 2 dm. high, with short leaves, and simple, dense, obloug panieles 1.5 to :3 cm. long. - P'oor, grivelly soil, hillsides, etc., Texas to Arizona. north to Colorado and Indian Territory. [Northern Mexico.] April-June. 


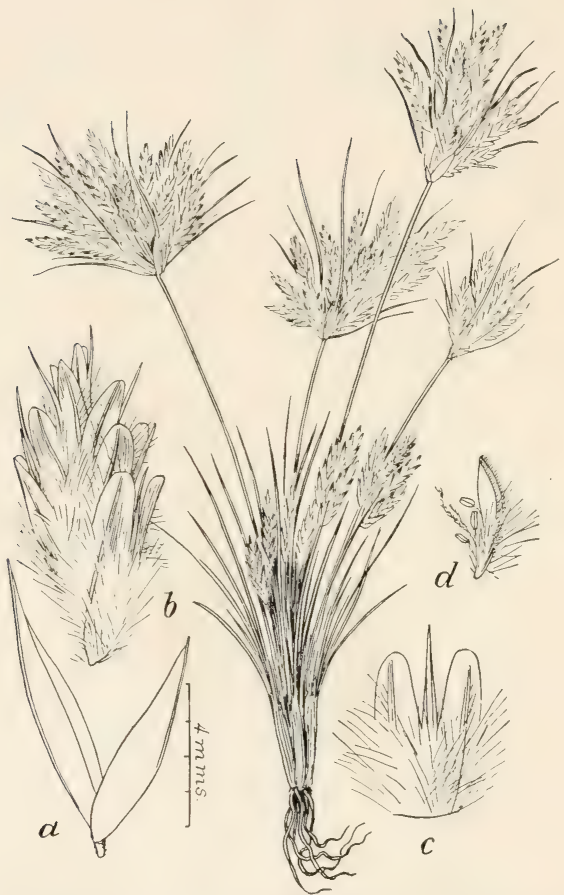

FIG. 236. Triodia pulchella HBK. (Sieglingia pulchella Kuntze); Beal, Grasses N. Am., 2: 465.-A low, densely tufted and often creeping perenuial 2ै to 1 is $\mathrm{cm}$. high, with very narrow leaves and crowded spikelets in clusters of three to six, which are equaled or exceeded by the upper leaves. - Western Texas to Nevada and southern California. [Northeru Mexico.] Felıruary-June. 


\section{5}

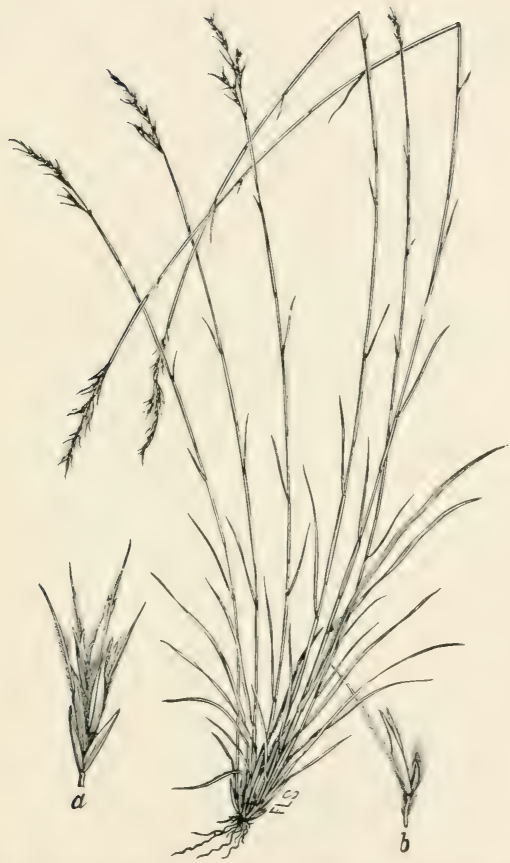

FIg. 237. Triplasis americana Beaux. Nieglingin americana Beal, (irasses X. Ant, $2: 466$ ). - - A slender, cirspitose grass, with wiry eulms 4 to $9 \mathrm{dm}$. high, rather short, narrow leaves, and fewthowered, simple panicles 3 to $10 \mathrm{~cm}$. long; the pubescent awns is to $7 \mathrm{~mm}$. long.-Dry, sandy soil near the coast, North (arolina to Mississippi. July-October. 


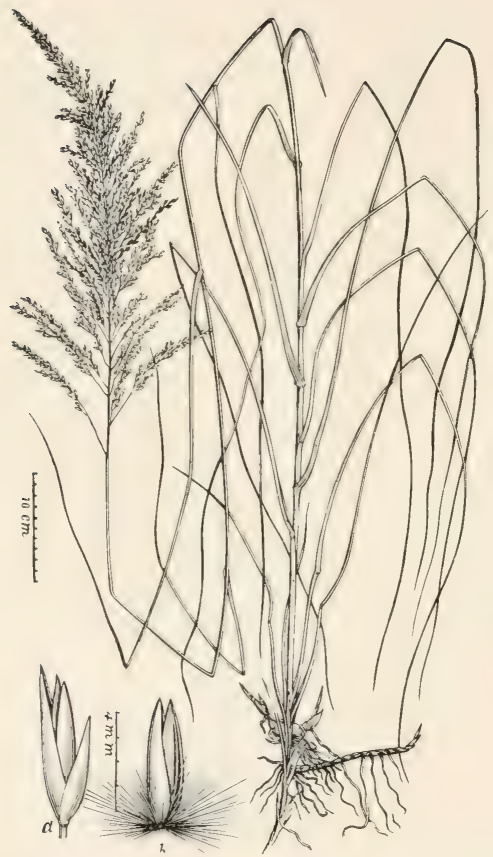

FI(. 238. Redfieldia flexuosa (Thurb.) Vasey (fraphephorum (?) Hexиosum Thurb.): Britton and Brown, Ill. F1., 1: 186. REv. FIELD's-(iRASS. - A stout, native pereunial 6 to $12 \mathrm{dm}$. high, with very long, narrow leaves aul diftuse, capillary panicles 25 to 60 cm. long. - Sand hills and "blow-onts," Kansas and Nebraska to Indian Territory, Colorado, and Wyoming. July, August. 


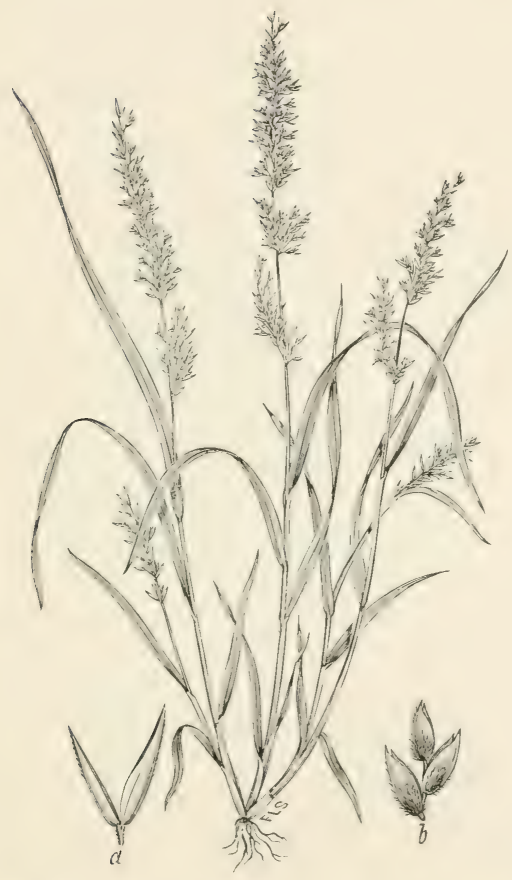

FI(;. 239. Dissanthelium californicum (Nint.) Benth.: Beal.

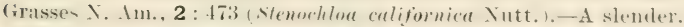
glabrous, hranching annual 1 to 3 du. high. with short, narrow leaves and contracted, spike-like pandeles 1 to $8 \mathrm{~cm}$. Jong. - santal Catalina Island, southern California, and filatilumpe Islands, Lower California. September. 


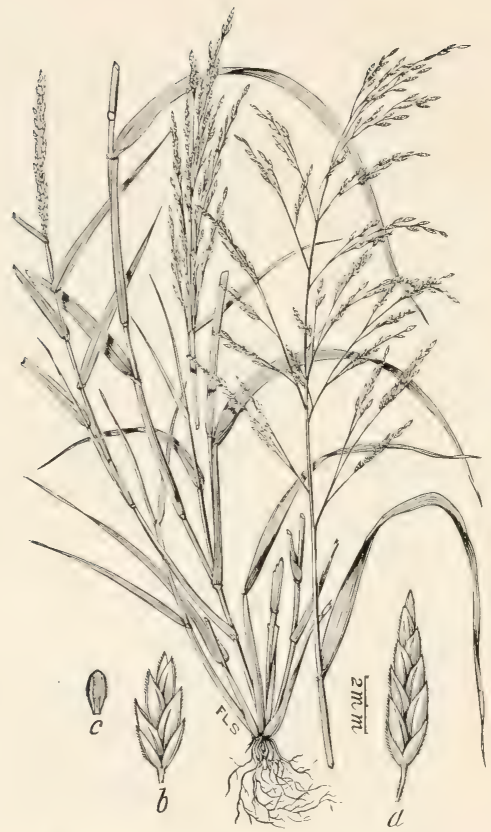

FIG. 240. Eragrostis neo-mexicana Vasey; Beal, Grasses N. Am., 2: 485. Crab-Grass (n New Mexico).-A rather stout, lranching and leafy annual 3 to $12 \mathrm{dm}$. high, with flat leares and ample, diffuse panicles 20 to $40 \mathrm{~cm}$. long. - Texas to sonthern ('alifornia (ascends to $1,500 \mathrm{~m}$. in Irizona). August. A valuable has grass resembling 'Teft' (E. abyssinica). 


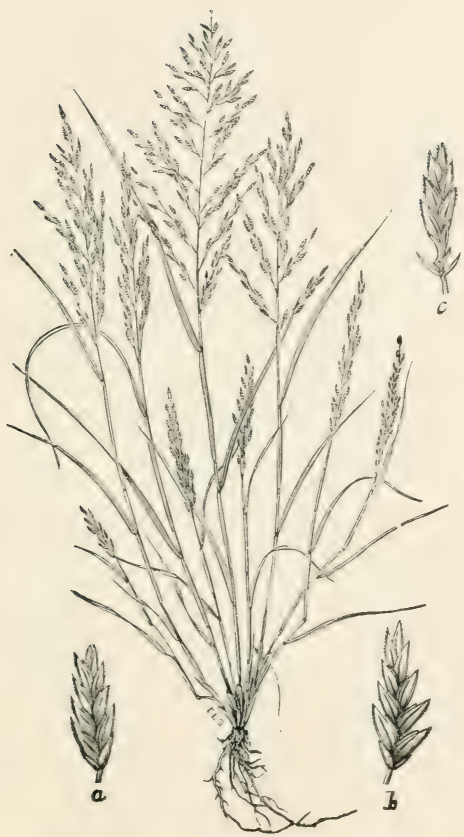

Fri. 241. Eragrostis purshii schral. Solthlix spentcilass.-An annual, 1 to $4 \mathrm{dm}$. high, with the erect or ascending culus dithuely lnanching near the hase, and dittuse panicles of small, sprealing spikelets. - Sandy river banks, waste gromel. ete.. Matssatebusetts and ontario to south hakotat and ('alifornia. south to Flerida. Texas, and Irizona. [Mexico.] Iune-1).toleer. 


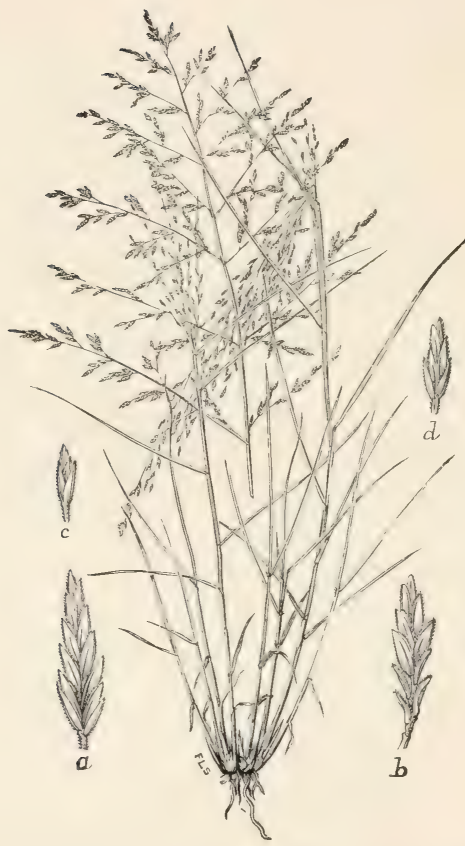

Fisi, 242. Eragrostis curtipedicellata Buclil.; Britton and Brown, Ill. Fl., 1: 190. SHoRT-STaLkED Eranirostis-A rather rigisl, branching perennial 3 to $9 \mathrm{dm}$. high, with flat, spreating leaves and diffuse panicles 20 to $30 \mathrm{~cm}$. long. Related to E. pectimucen.-Prairies. Kansas, Indian Territory, and Texas. JulySeptember. 


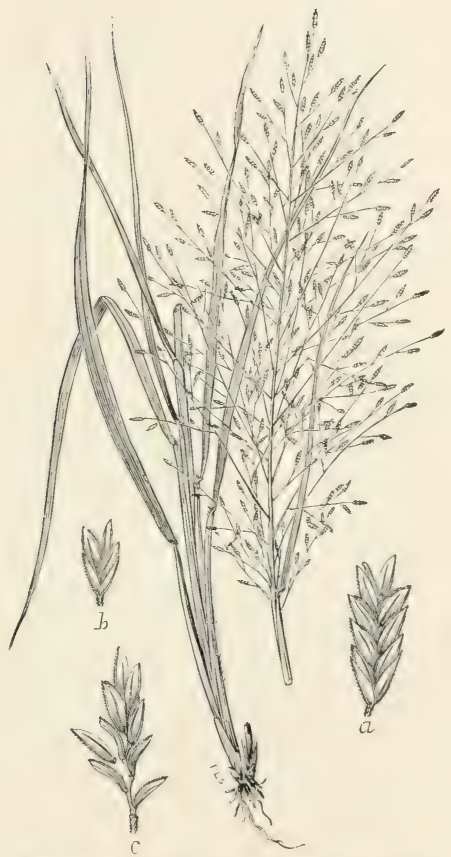

F11, 213. Eragrostis pectinacea (Michx.) Ntend.-An erect, "aspitose perennial 3 to 9 , lu. high, with a short, stout rootstock and large, spreading, red-purple panieles.-1)ry, samdy soil in the open, Massichusetts to South Dikotit and ('olorado, south to Florida and Texas. July-Oetober. 


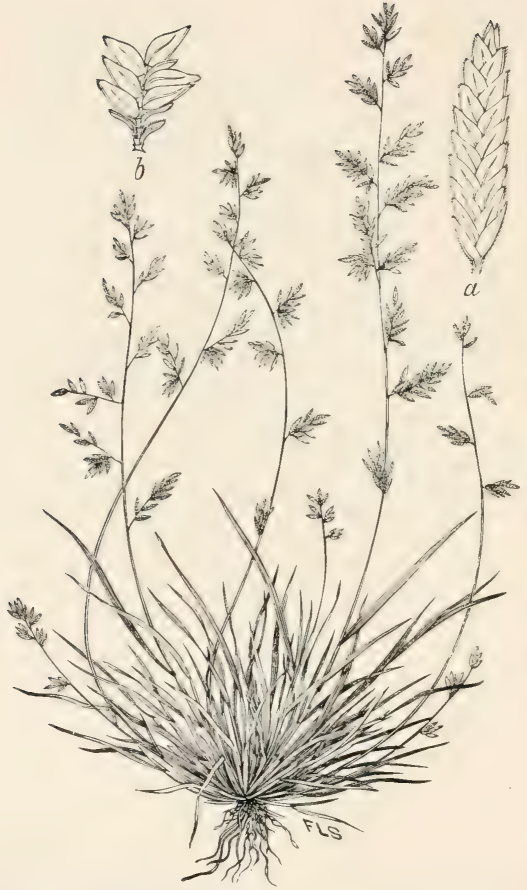

FIG, 244. Eragrostis brownei Nees (?).-A wirlely spreatling, branching perennial, with somewhat wiry culms 2 to $5 \mathrm{dm}$. long, and narrow, simple, more or less interrupted panicles of nearly sessile, ten- to forty-Howeresl spikelets.-Dooryards and waste gromud, Florida. [Widely distributed in tropical and subtropical regions.] July-October. 


\section{3}

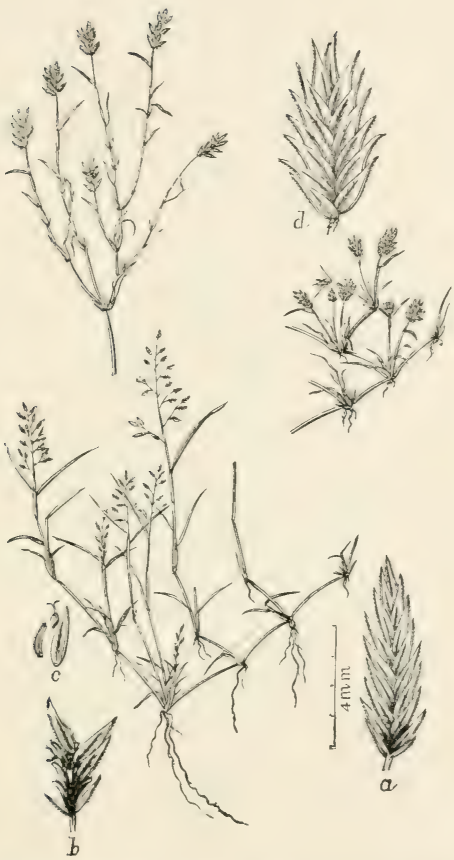

Fig. 245. Eragrostis hypnoides (Lam.) B. S. P. (I'ua hypnoides Lam.; E. reptums Nees).-I prostrate, much-hranched, and extelisively creeping annual, with ascending, flowering batuches $7 . .5$ to 15) cou. high, spreading leaf blates, narrow and lax or very dense panicles and long, linear-lanceolate, strong!r ampressed spikelets.-In ditehes anel samely hanks of streams, Vormont and Ontario to Florida, Texas, C'alifornia, and Washington. [Mexico, West Indies, and South Ameriea.] March-October. 


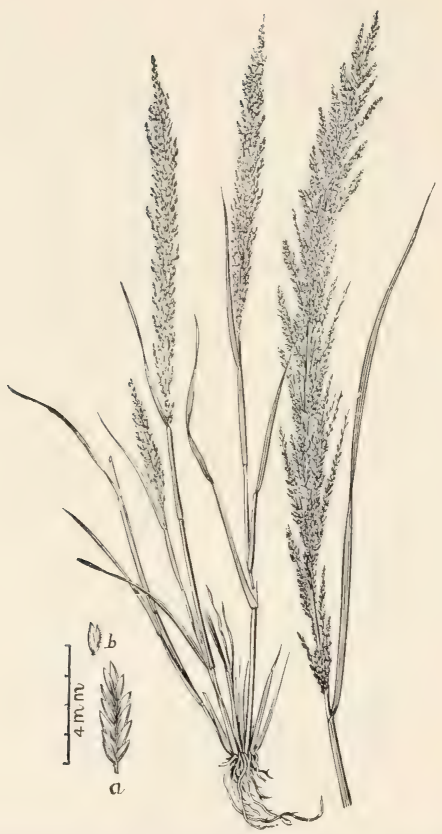

FIG. 246. Eragrostis glomerata (Walt.) L. H. Dewey (Poa glomerata Walt.; P. conferta Ell. : Eragrostis conferla Trin.).-An erect, rather stout, liranching aunual 6 to 9 dm. high, wirh smooth sheaths and leares, and elongated, densely tlowered, light-colored panicles 25 to $60 \mathrm{~cm}$. long. - Low groumrls, South Carolina to Florida and westward to Texas. [Cuba, Mexico, and south America.] August-Norember. 


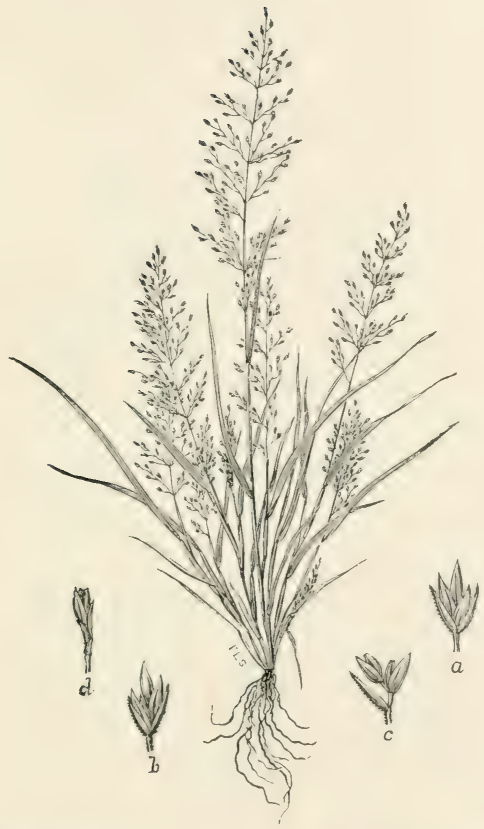

Fiti, 217. Fragrostis frankii stend. SHORT-STALKEn ME.nowGRass.-A low, difîsely branched annual $0 . x$ to $1.5 \mathrm{dm}$. high, with open, many-flowered panieles 5 to $12 \mathrm{~cm}$. long.-Low, samdy ground in the open, sonthern New York to Minnesot:i, south to Georgia, Louisiana, and Kansas. August-October. 


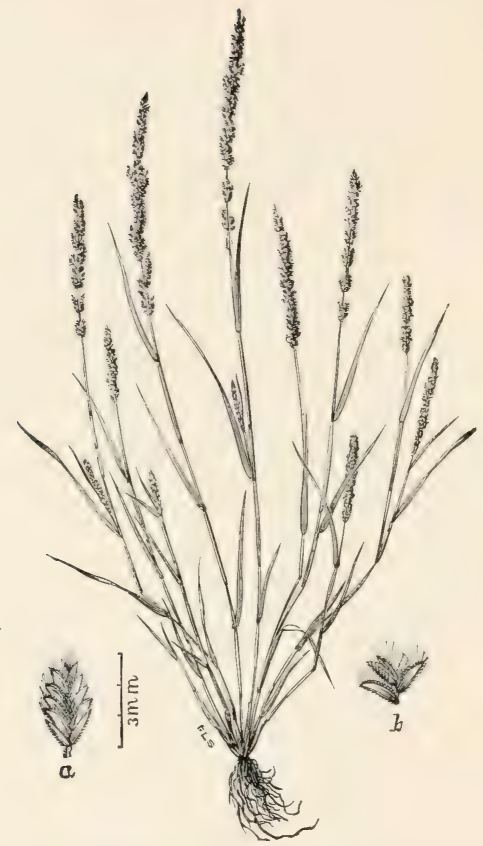

FIf. 248. Eragrostis ciliaris (L.) Link (Poa ciliaris L.).-A dittusely branching, slender annul 2 to $5 \mathrm{dm}$. high, with thin, narrow leaves and densely flowered, cylindrical, spike-like, more or less interrupted panicles 5 to $10 \mathrm{~cm}$. long.-Cultirated and waste ground, Georgia and Florida to Mississippi. [Mexico, West Indies, and Asia.] July-October. 


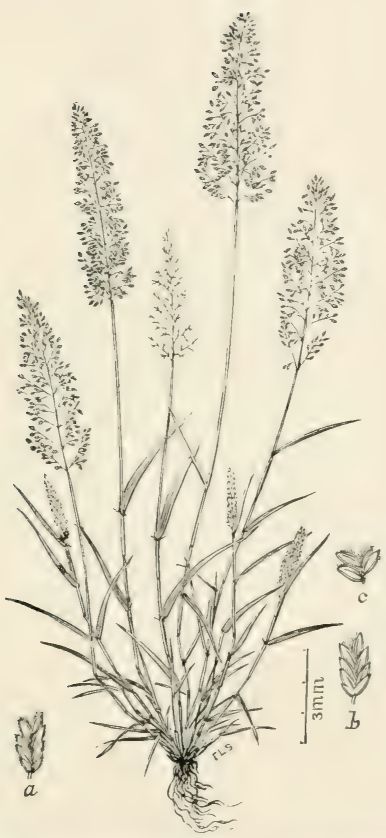

Frf. 249. Eragrostis plumosa Link.(E. ciliaris patens Chapm.).A slender, dittusely brauching anmual 1 to $t$ lm. high, with flat leaves and oblong, open panicles is to 15 .'m. long. - ('nltivated and waste ground, southern Georgia and Florida. [Widely distributed in tropical countries.] July-November. 


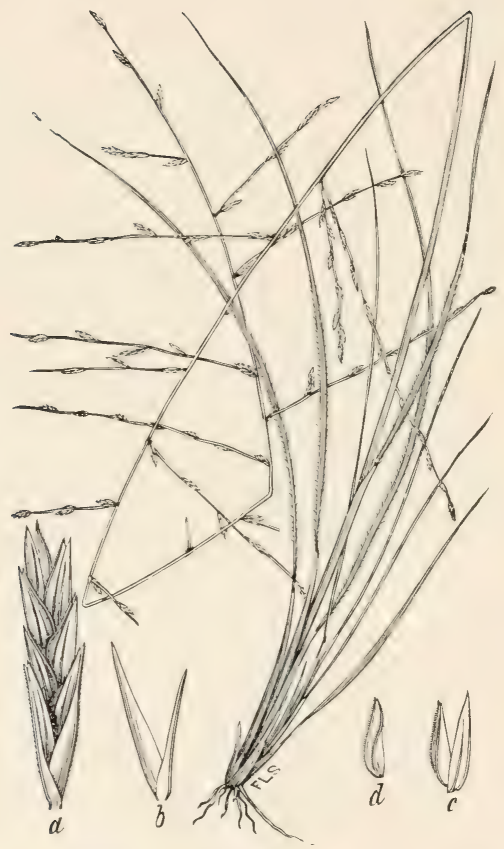

Fig. 25). Eragrostis sessilispica Buck1.; Britton and Brown, Ill. Fl., I : 190 (Diplachene rigidle Vasey).-A smooth, wiry, cueppitose peremnial 3 to $9 \mathrm{dm}$. high, with narrow, mostly involute leaves and pramidal panicles, the tive- to twelve-flowered, appressed spikelets sessile along the spreading hranches.-Dry prairies, Kansas to Texas. June-October. 


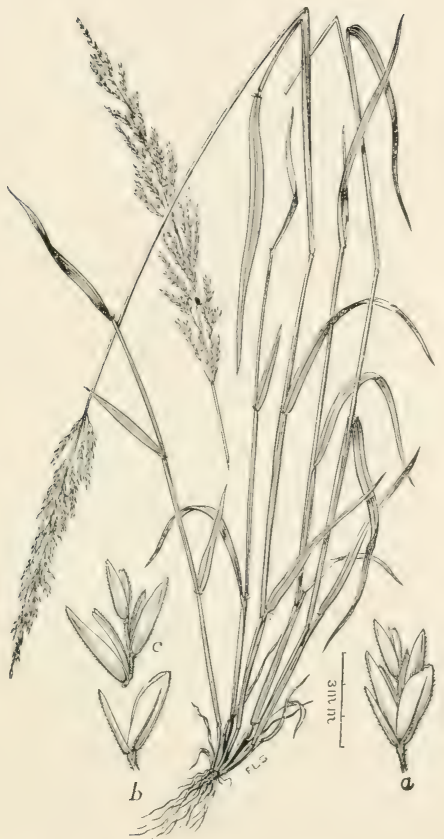

Fr(i, 251. Eatonia pennsylvanica (D) .) .1. (iray. E.tTux's(ands- - A slender, pale-green perennial, with flat leal blades and narrow terminal panieles. - Wet meadows, low words, and thickets, Newfoundland aud Mane to British Columbia amd Washington, sonth to fieorgia, Mississippi, Texas, and Arizona. AprilAugust. 


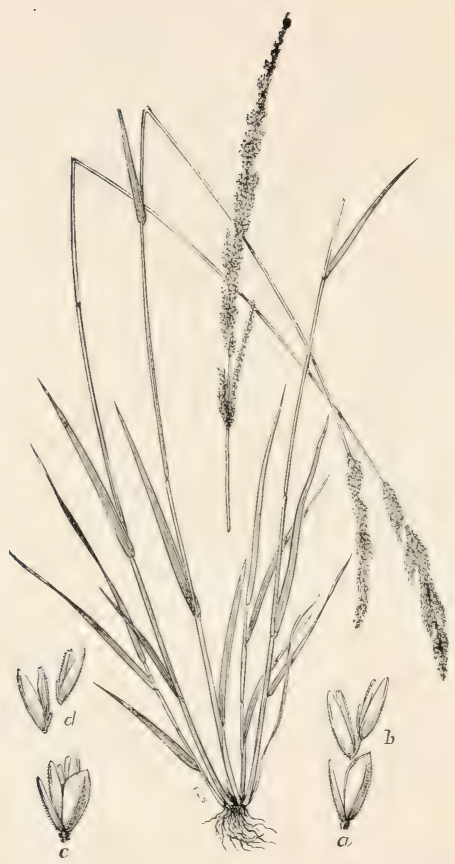

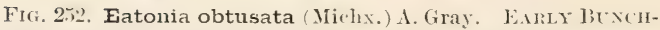
(indss.-A tufted perennial 4.5 to 6 dm. high, with bat leaf blades and rather densely flowered, norling panicles,-low gromud, (hietly along streams, usually in shade. Massachusetts and ontario to Assiniboia and British (oluml,ia, sonth to Florisla, Texas, and southern California. Mareh-August. 


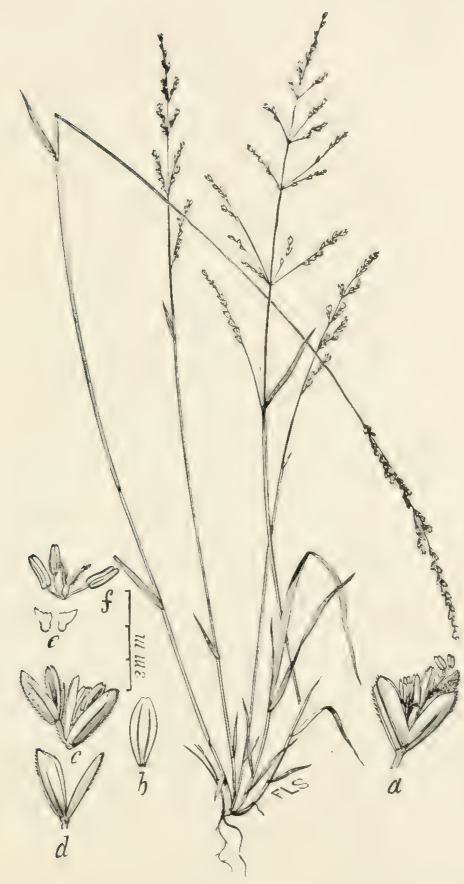

FIti, 253. Eatonia nitida (sprengel) Nash (Aira nitide Spr.; Eutonia dudleyi Vasey).-1 slender, erect, and carspitose perennial 3 to 6 dun. high, with short, flat, spreading leaves and rather few-flowered, nodling panicles.-1)ry, open woodlands, Rhole Island and Vew York westward to Forth Dakota, and soutliward to North Carolina, Mississippi and Texas. Ipril-, Iune. 


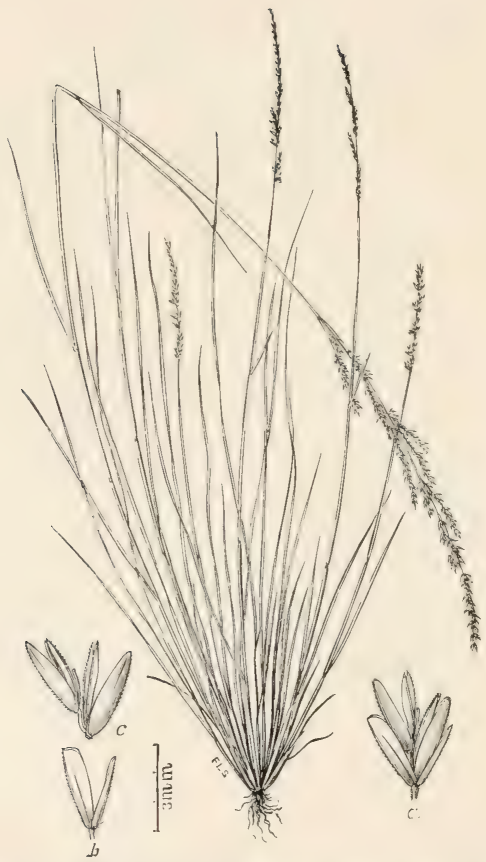

Fit, 251. Eatonia filiformis (Chapu.) Vasey; Heal, (irasses, $\mathrm{N}$. Am., 2 : 491.-An erect, tufted perennial 3 to $6 \mathrm{~cm}$. high, with very long upper internodes and long, involute, radical leaves.- Iry, sandy soil, Sonth Carolina, Floricla and Texas, north to western Tenuessee. March, Apri]. 


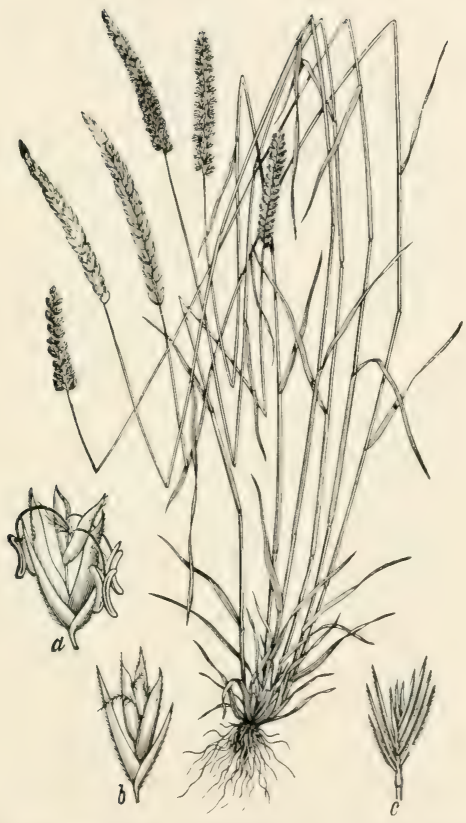

Fiti. 25. Cynosurus cristatus L. DoG'S-TAIL-Griss.-A slender, erect perennial 3 to $7 \frac{1}{2} \mathrm{dm}$. high, with narrow leaves and rather slenter, erect, spike-like panicles.-Sparingly establisher in fields and waysides, Nowfoundland to Ontario, sunth to New Jersey; Portland, Oregron. [Europe.] June-August. 


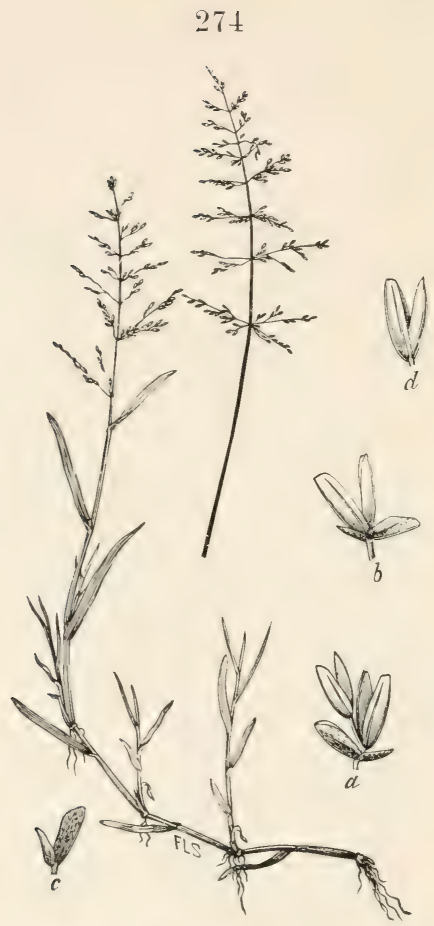

Fit. 256. Catabrosa aquatica (L.) Beauv.; Jritton and Brown, Ill. Fl., I: 194. WATER WHORL-tiRass.-A smooth, soft peremuial, with creeping or ascending enlms 2 to $6 \mathrm{dm}$. long, flat leaves and open panicles 5 to $20 \mathrm{~cm}$. long, the spreading branches in whorls.-In swales and along brooks, often in shallow water, Newfoundland and Labrator, to Quebec and Alaska, south to Nelraska, Colorado, and Utah. [Europe and Asia.] June-August. 


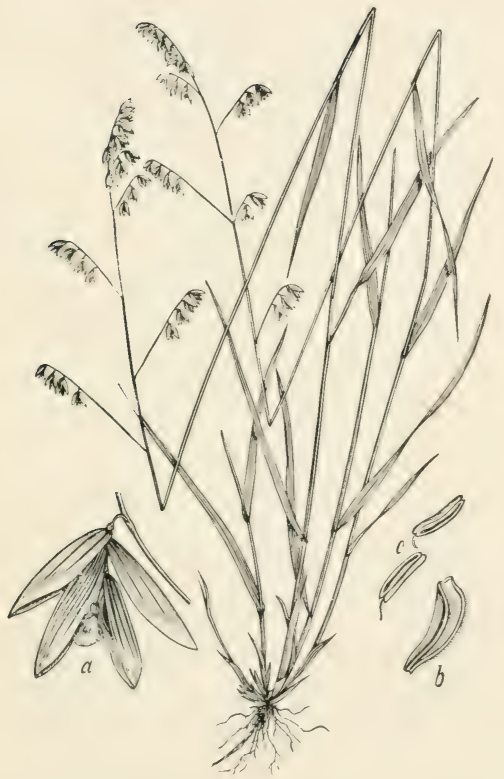

Fif. 257. Melica mutica Walt. ( $M$, glulma Mx.),-A slender, loosely caspitose, wirg grass 6 to 9 dm. high, with that leaves and simple or racemose panicles of rather large, nodding, two-to threeflowered spikelets.-I)ry, rooky, open wools and thickots, P'ennsylania to Florida and Westward to Wisconsin and Texas. March-Jlay. 


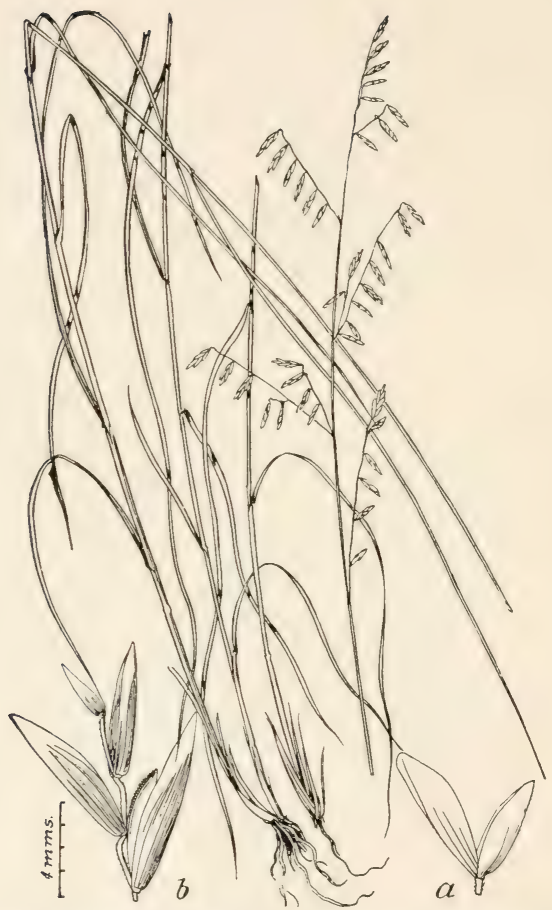

Fig. 258. Melica parviflora (Porter) Seribn. (M. mutica parriflora Porter; M.porleri. S.ribn.).-A rather slender, erect, smooth perennial 4 to $7 \mathrm{~lm}$. high, with flat leaves and uarrow pauicles 15 to $25 \mathrm{~cm}$. long. Spikelets pendulous and racemose along the panicle branches.-Chaded eanyons, monntains of C'olorado, New Mexico, Arizona and prairies of Missouri, Kinsas, and western Texas. [Northern Mexico.] July-September. 


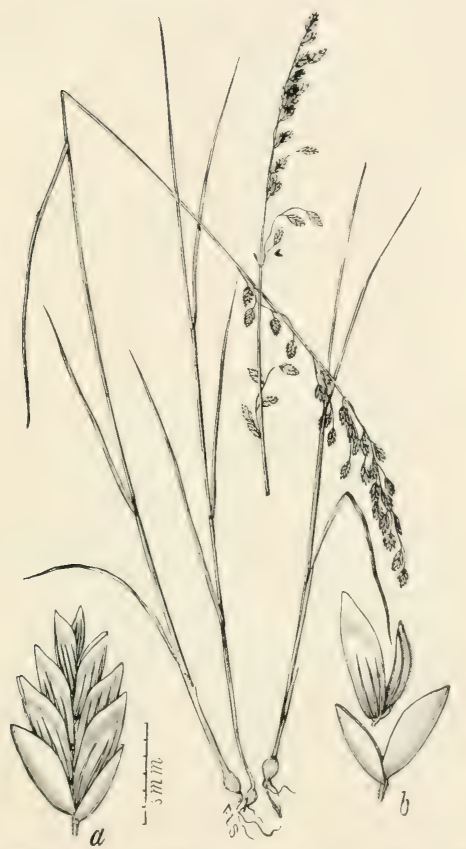

F14. 259. Melica spectabilis Seribn.; Beal, (irakies N. Am., 2: 51)6. - $\mathrm{A}$ cerspitose, stoloniferous species 3 to $6 \mathrm{~cm}$. high, with scahrous, flat leaves, and loosely flowered, nodding, simple panicles 10 to 20 ('m. long. - lanp grassy meadows, rich bottom lands, (Iry hillsides, ete (alt. 9.50 to2, $400 \mathrm{~m}$.). Montana to Washington and ()regon, south to Colorado, Wyoming, and Nevada. June-September. 


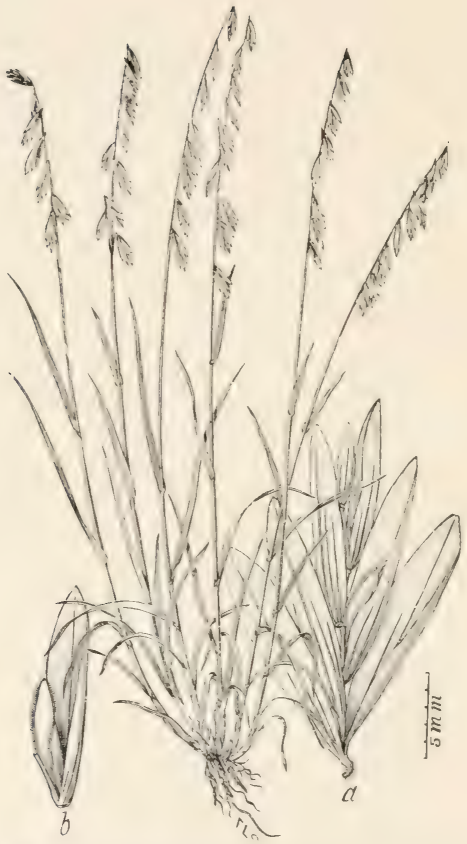

FIG, 260. Melica stricta Bolanul. Beal, (irasses X. Am.. 2 : 503.

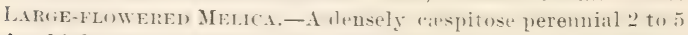
dm. high from a bulbous hase, with flat. more or less pubuscent leaves, and simple, one-sided panicles $10 \mathrm{to} 15 \mathrm{~cm}$. long, bearing ten to twenty spikelets.-I)ry rislges among rocks ialt. 1,850 to $2,700 \mathrm{~m}$. , Nerada, ('alifornia, and Oregon. June- Ingust. 


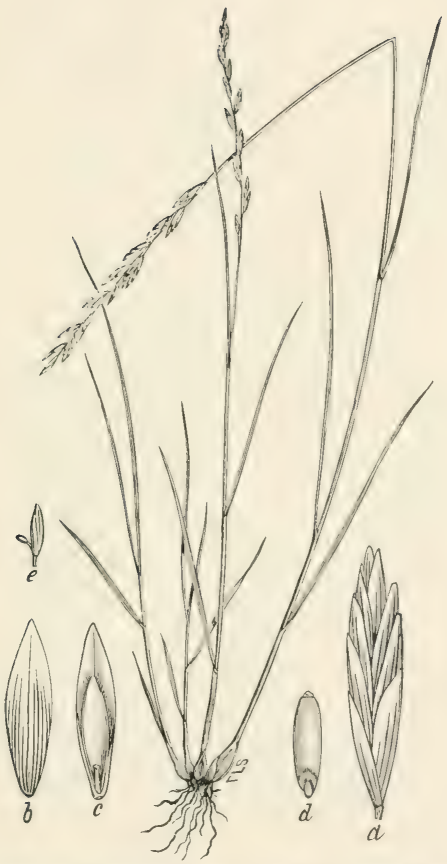

Fin. 2011. Melica bulbosa (ieyer; Beal, (irasses N. Am, 2 : 50).

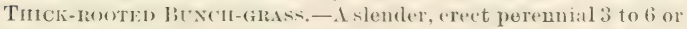
rarely 9 dm. high, bulbous at the hase, with erect leaves and at narrow. somewhat spike-like panicle 10 to $1.5 \mathrm{~cm}$. long.-Dry rocky slopes, moist shady mount ain sides, ete. (alt. 900 to 2,700 m.). Montana and Wyoming to British Columbia, south to Utah, Nevadis. and Oregon; western Texas. May-July. 


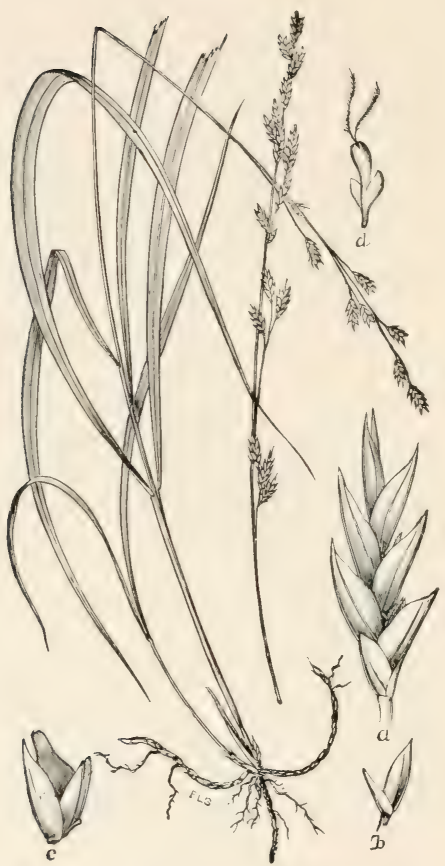

FIG. 262. Korycarpus diandrus (Michx.) Kuntze: Britton aud Brown, Ill. Fl., I: 196; (I)iarhena americana Beaur.).-An erect perennial 6 to $9 \mathrm{dm}$. high, with long, narrow-lanceolate, nearly erect leaves and a few-flowered, simple panicle 10 to 25 cm. long,-Rich, rocky, wooderl hillsides, Ohio to South Dakota, sonth to Georgia, Arkansas, and Indian Territory. August, September. 


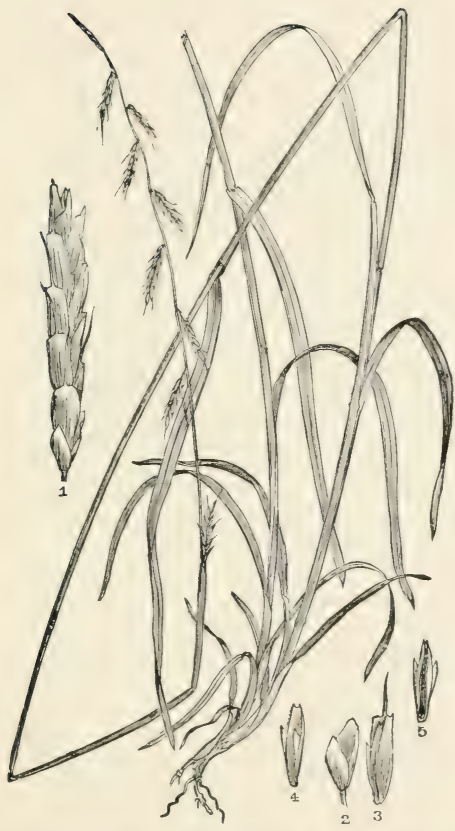

Fig. 26:3. Pleuropogon refractum (A. (iray) Benth. (Lophochlerna refrecta A. Gray); Beal, Grasses N. Am., 2 : 514. Nomble: Plecloporiox.-I slemler perennial o to $12 \mathrm{dm}$. high from creeping rootstocks, with flat leaves and terminal racemes of six to ten drooping spikelets 2 to $3 \mathrm{~cm}$. long.-In swamps ancl along mountain streams (alt. 1,200 to $3,850 \mathrm{~m}$.), ('alifornia to Washin ton. May-August. 


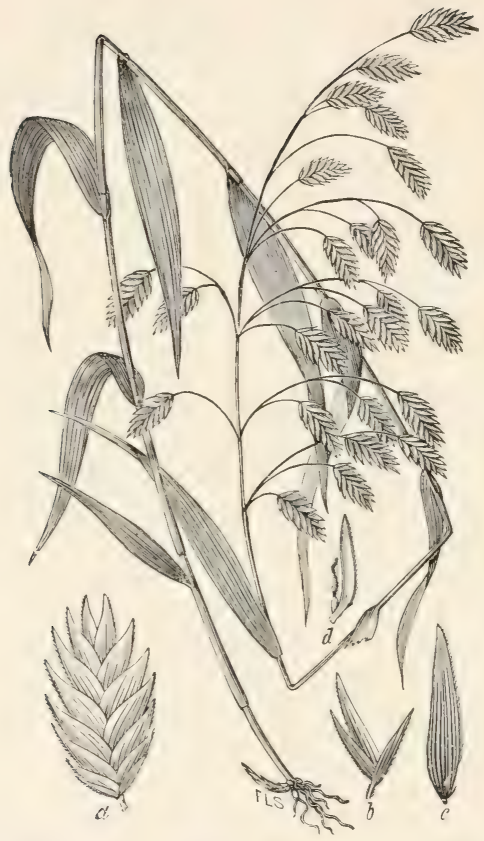

FIri, 261. Uniola latifolia Michx. Broad-LeafeI SPIKE(ilass.-An erect grass, with rather stont, simple culms 6 to 12 dm. high. hroat, spreating leaf blates and a drooping panicle of large, flat spikelets "2 to 3 em. long.-Low thickets and shader hanks of streams. Pennsylvania in Florida, west to Illinois, Kansas, and Texas. June-October. 


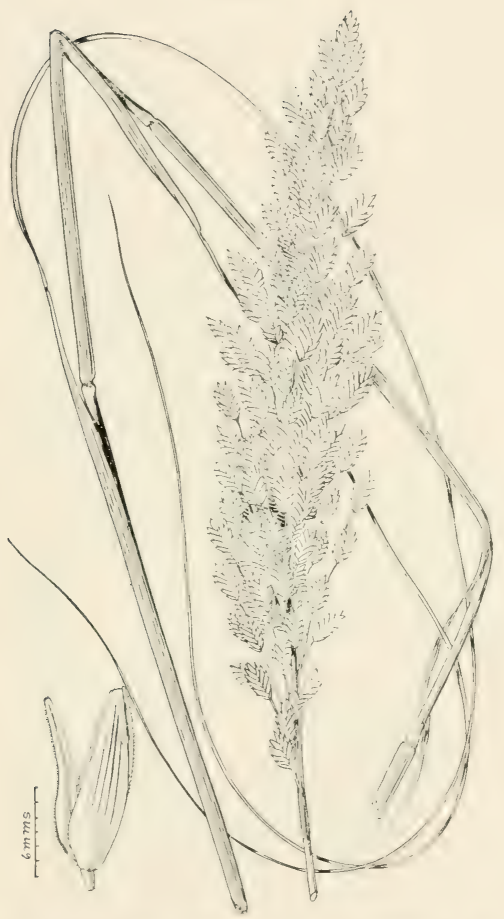

Fr1, 265. Uniola paniculata I., lieal, (irasses N. . Im., 2 : .516. SEASIDE OATs.-A stont, native perennial ! to $15 \mathrm{dm}$. high, with long, rigid leaves and sloww, nodeling panieles of many loroat and palo straw-eolored spiliolets.-Drifting sand of seal bea hes, Virginiat to Texas. [Wust Indies and south America.] MayOetober. 


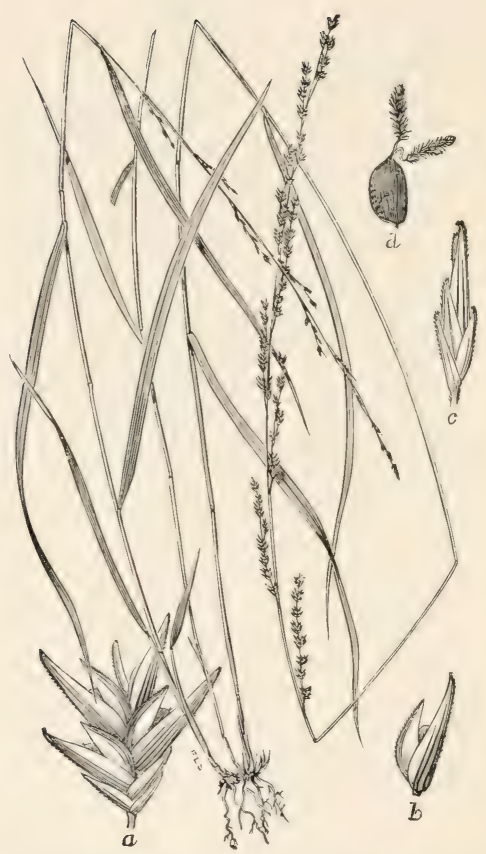

FI(r. 266. Uniola laxa (L.) B. S. P. ; Brit tou and Brown, Ill. Fl., 1: 197 ( $C$.gracilis Michx.).-A slenter grass 6 to 9 dm. high, with long, narrow leaf-blades, and a contracted, wand-like, nodilng panicle 15 to 45 cm. long.-In dry soil, open woods, and banks, Long Island to Florida, west to Kentucky, Temmessee, and Texas. June-Oetoluer. 
285

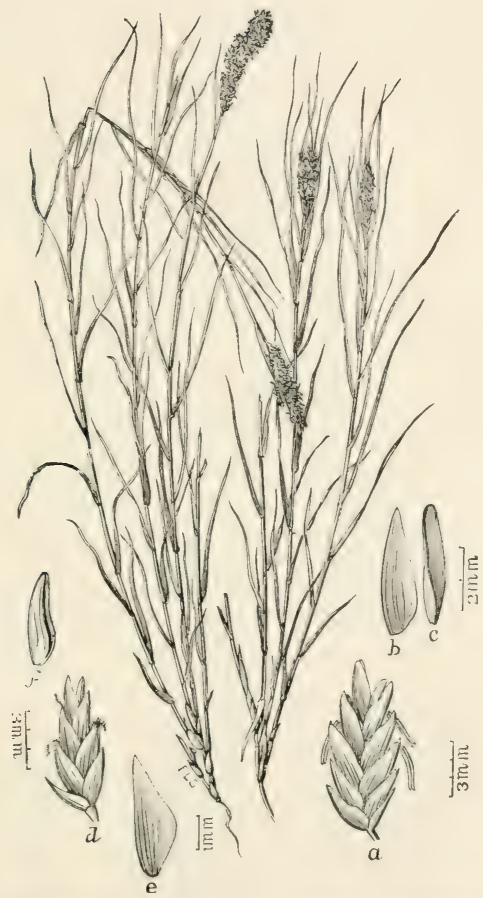

FIr. 267. Distichlis spicata (L.) Greene; liritton and Brown, Ill. Fl., 1: 198 (J). maritima Raf.). AlKali-(ilass.-An upright, wiry grass, 2.5 to 5 dm. high, with strong and widely ereeping rontstocks, rather rigid leaves, and densely flowered panicles. The grass is direious. - Salt marshes along the coast, Maine to Texas and British Columhia to California ; alkaline soil in the interior, Nebraska and Kansas to Montana, eastern Washington, California, and New Mexico. May-August. 


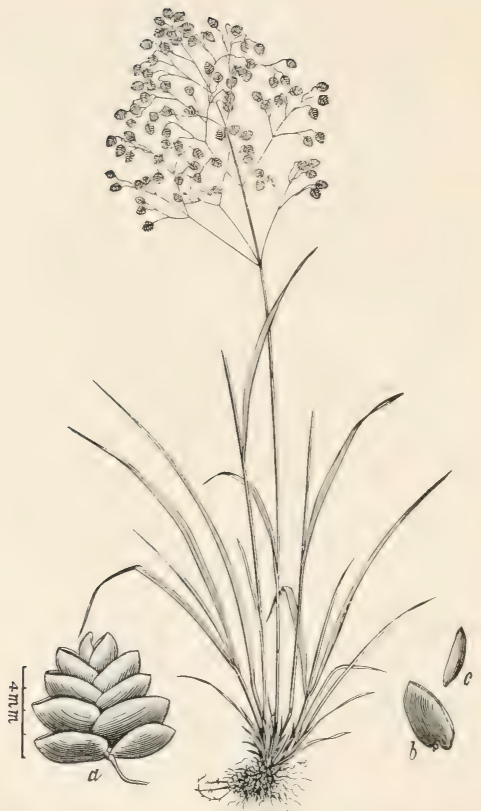

Fig. 268. Briza media I. QTAKING-Grass-A slender, erect perenuial, with rather short, llat leaf-blades and 'apillary, spreading panicles._- Fparingly naturalized in fields and waste ground, in Ontario, New Engiand, and Californit. [Enrope aud Asia.] MayJuly. 


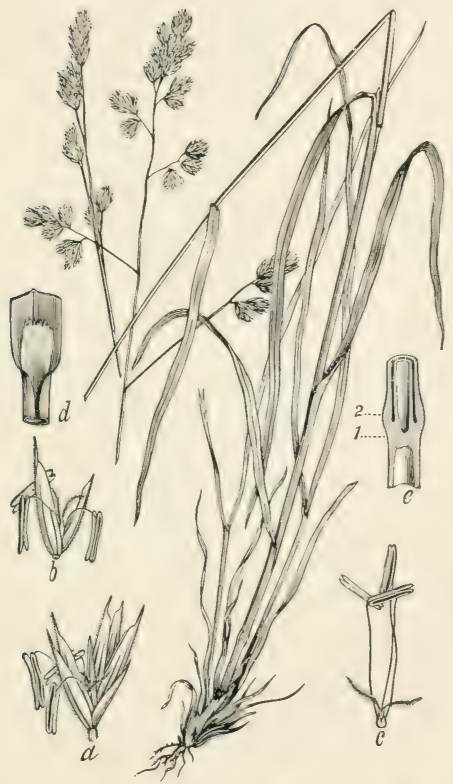

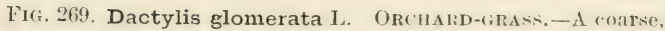
erect grass 9 to 12 dm. high, forming dense tufts, with long, tlat leat biales, and spikelets erowhed in dense, one-sided clustris' at the emes of the paniele branches.-Extensively naturalized in fielils and waste groumd, New brunswiek to fonth ('arolina, west to Manitola, Idaho, and Colorado. [Europe.] May-August. 


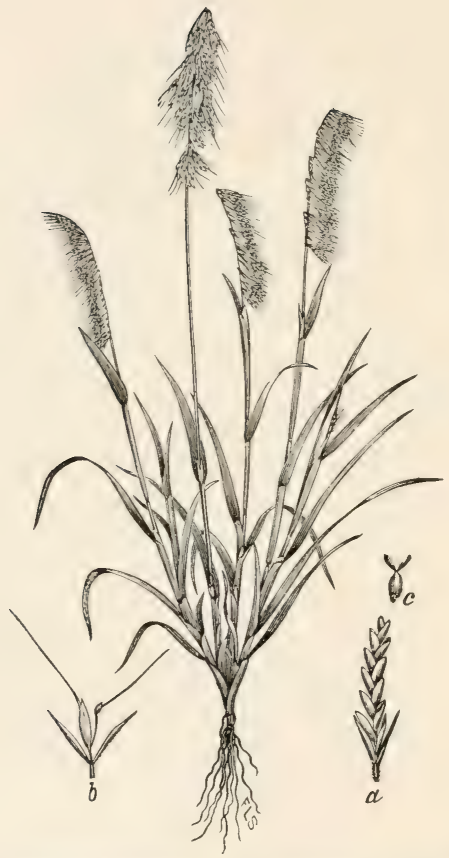

Fiti. 270. Lamarckia aurea (L.) Moench. Golden-TOP.-A cespitose, branchmg annual 1 to $3 \mathrm{dm}$. high, with elegant onesided panicles 5 to $8 \mathrm{~cm}$. long.-Introduced into southern and Lower California. [Southern Europe, northern Africa, and Australia.] March-May. 


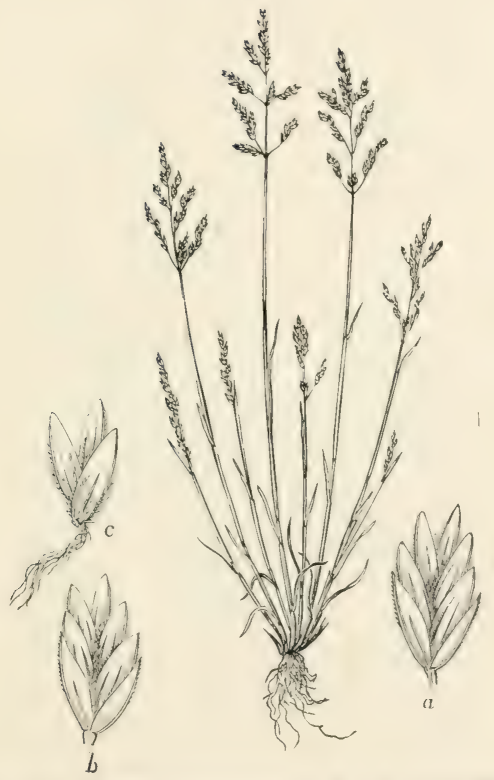

Fr: 271. Poa chapmaniana Serihm.-A low, cirspitose ammual 1 to 2 dm. high, with ascending, flat leaves and usually narrow panicles 2 to 8 cm. long. Allied to $I$ '. annun, hut more strict in habit of growth.--Dry sancly soil, southern Illinois to Mississippi and Georgia. April, May.

$11162-$ No. $7-19$ 


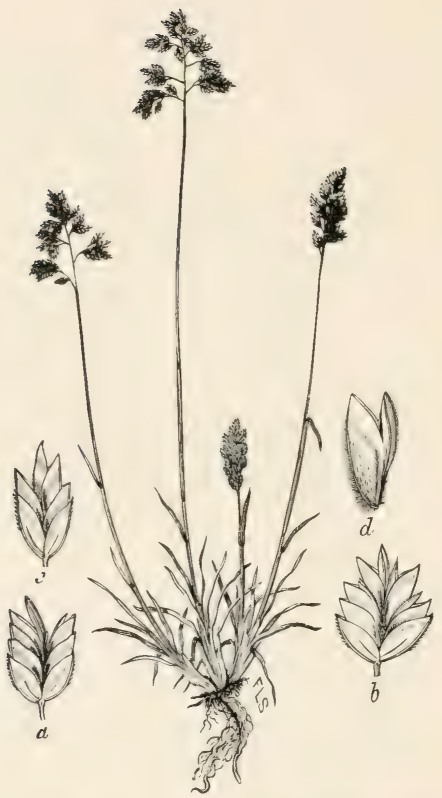

Fig. 272. Poa alpina L. Mocntain Speali-iliass.-A slender or stout, eiespitose, erect perennial 0.5 to 3 (usually 1.5 ) dn. high, with rather broad, flat leaves, and spreading pyramidal panicles of comparatively large spikelets. - Edges of brooks, open grassy mountain slopes, canyons, ete., Newfonmdland and Quebec to Hudson Bay and Alaska, south in the mountains to Colorado (alt. $3,600 \mathrm{~m}$.), Utah and (alifornia. [Widely distributed, aretic and subalpine.] June-August. 


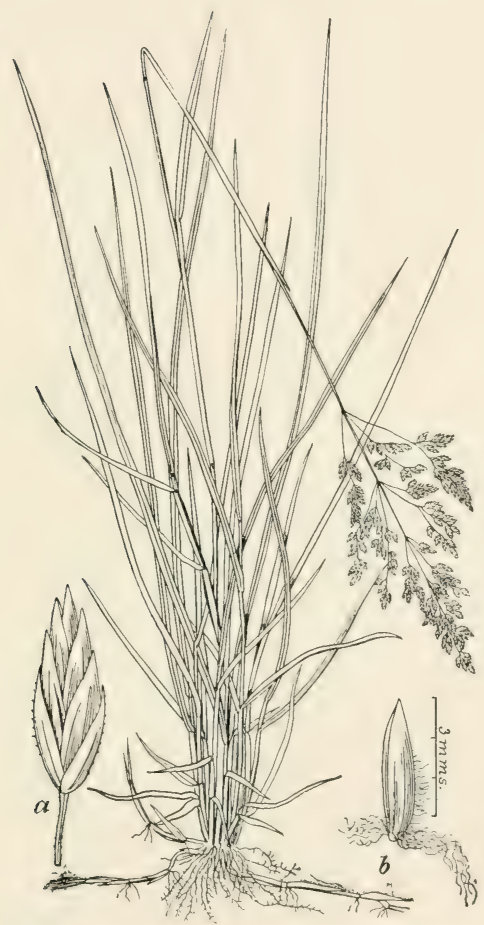

Fig. 273. Poa pratensis L. Kentucky Bite-grass. - A slender, erect, stoloniforous perennial is to ! dm. high, with narrow, llat leaves and more or less sprealing. usually pyramidal panicles. Fields and meadows throughont the l'nited states and British Ameriea, ahmolantly naturalized in the Fast, indigenoms in the North and West. [Europe and Asia.] Summer. I valuable pasture grass. 


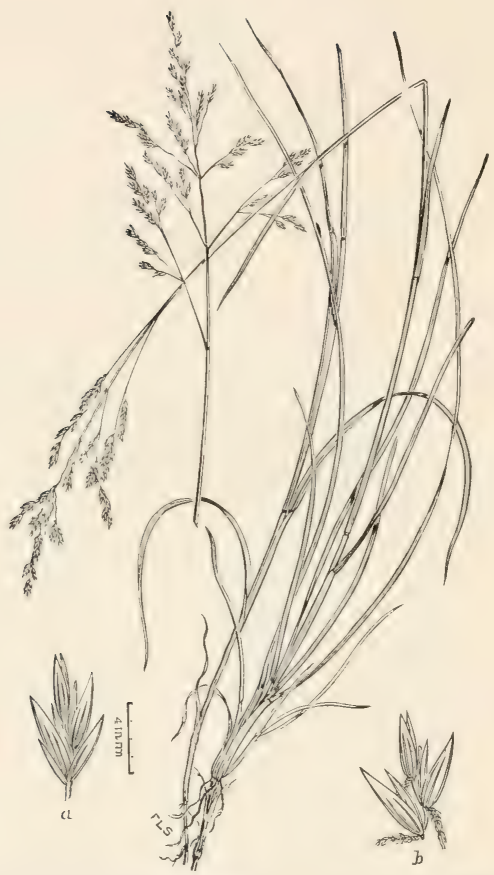

FIG. 274. Poa kelloggii Vasey; Ill. X. Am. Grasses, 2: 79. Keflogig's SPEAR-Grass.-A slenter, ereet or ascending perennial 4 to $6 \mathrm{dm}$. high, with rather long, llat leaves and open psramidal panicles 7 to $10 \mathrm{~cm}$. long. Spikelets two- to four-flowerel.California (4705 Bolauler). 


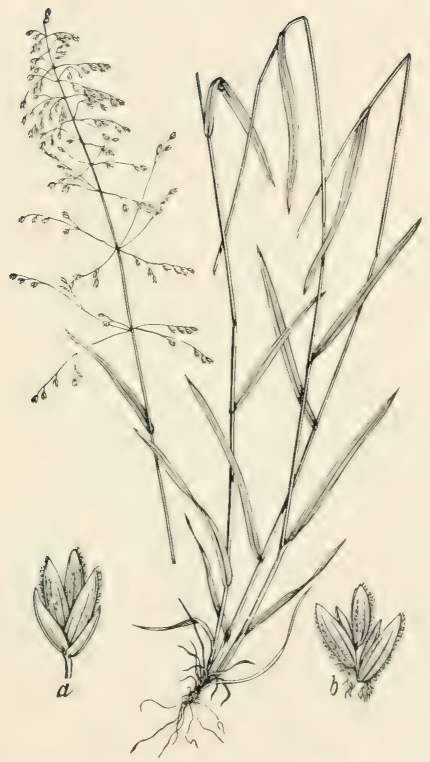

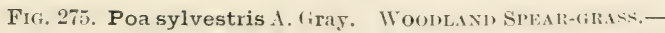
A slender, tufter perennial is to $9 \mathrm{dm}$. high, with an open panicle 10 to $15 \mathrm{~cm}$. long, the hranches spreading or reflexerl.-Rich woods and thickets, New York to Wisconsin and Melyrasia, south to North Carolina, Louisiana and Texas. April-July. 


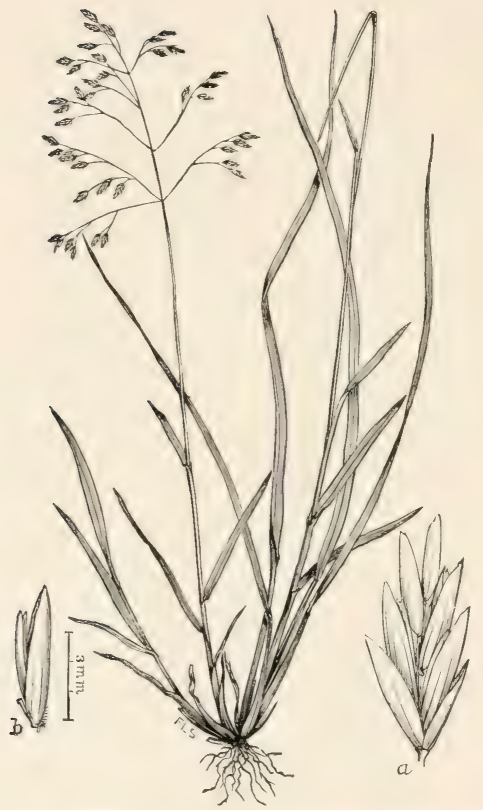

Fir. 276. Poa brevifolia Muhl. Solthers Spear-Grass.-An erect perennial 3 to $6 \mathrm{dm}$. high, with ruuning rootstocks, short culm leaves, and a widely spreating, few-flowered panicle.Wooded river bluff's and the grassy summits and wooded slopes of mountains, New Jersey to northern Ohio and Illinois, south to North Carolina and Tennessee. March-May. 


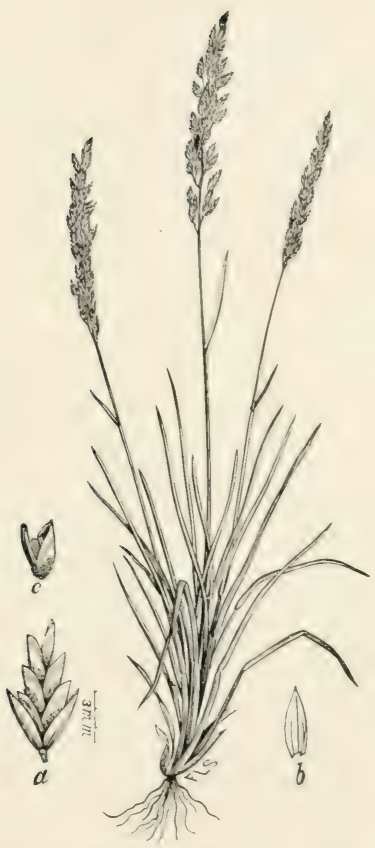

FIt; 277. Poa arida Vasey; Britton aud Brown, 111. F1.. 1: 2()\&.

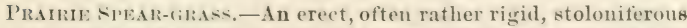
perennial 3 to 6 dm. high, with that or folded, stift leaves and narrow, rather densely 1lowered panicles 8 to 15 cm. long.-Meadows and low grounds, Northwest Territory to Kansas and Arizona. April-August. 


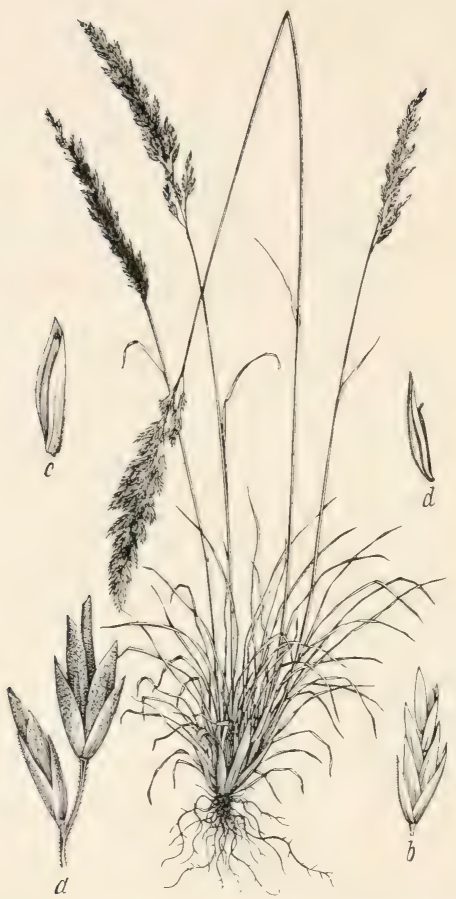

FIr. 278. Poa buckleyana Xash; Britton and Brown, Ill. Fl., 1: 208 (Poa tenuifolia Burkley). HCXCI RED-TOP.-A rather slender, erect perenuial "bunch grass" 3 to $6 \mathrm{dm}$. high, with mumerous, soft radiral leaves and a narrow panicle.-Isually in dry soil of "hench" lankls, mountain slopes, herated prairies, etr. (alt. 450 to 3,900 m.), South I) akota to British Columbia, Colorado, and California. May-September. 


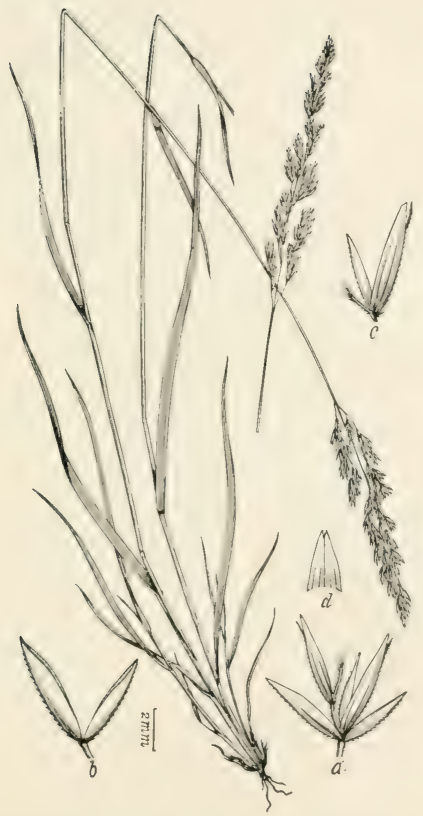

FIG. 279. Graphephorum melicoideum (Michx.) Beaur.-A rather slemler, erect, pale-green, carspitose peremial ; to folm. high, with flat leaves and loosely flowered, nodding panicles 7 to $11 \mathrm{~cm}$. long.-Rocky or gravelly river shores, low woods (sometimes pine woods), ete., Anticosti Island to Vermont, Michigan. and Northwest Territory. August, September. (Allied to Trisetum.) 


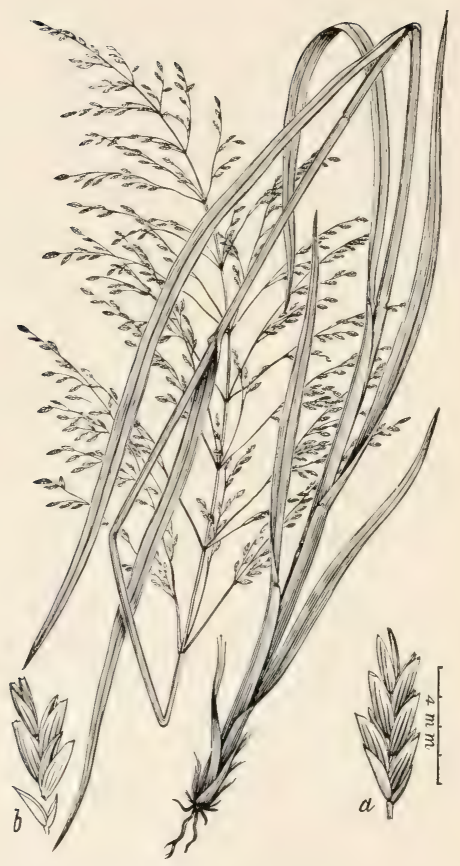

FIG. 280. Panicularia aquatica (Sm.) Kuntze (G7yceria aquatica J. E. Smith). REen MEADow-(rrass.-A stont perenuial 9 to 15 dm. high, with rather broad, flat leaf blades and an ample open panicle.-Shaded banks of streans, wet meadows, moist thickets, ete.. New Brunswick to Alaska, south to P'ennsylvania, Tennessee, Nebraska, New Mexico, and southern California. June-August. 


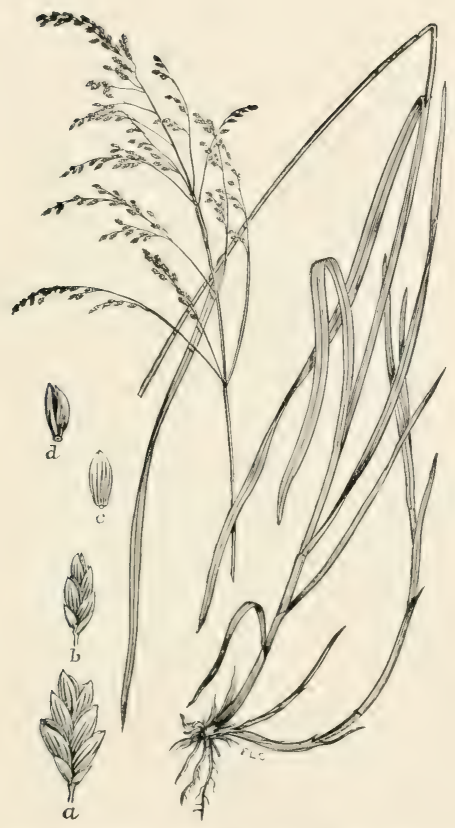

FIG, 281. Panicularia nervata (Willd.) Kunt\%e (Glyeeria nervata Trin.). Fow M MEADow-GRAss.-A leafy perennial 3 to 9 dm. high, with an expanderl, nodding panicle, and rather small spikelets.-Wet meadows, marshes, moist thickets, ote., Newfoundland to Florida, west to British Columbia, California, and Arizona. June-September. 


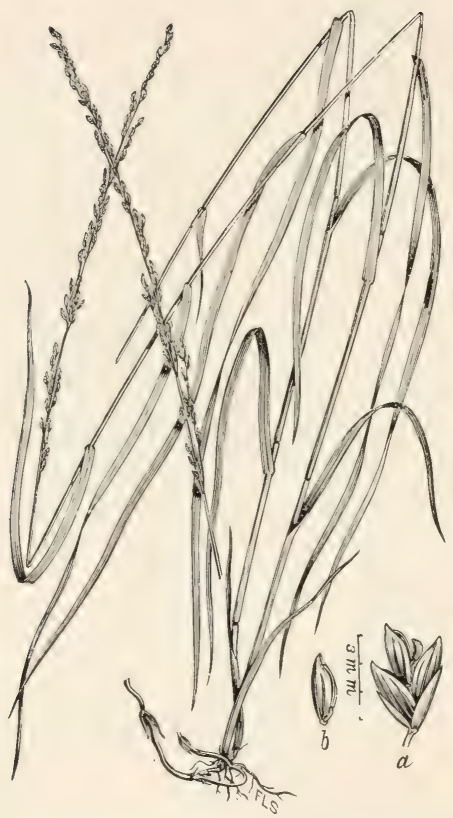

Fi(i, 28:. Panicularia elongata (Torr.) Kuntze (Glyceria elongatu Trin.) (Poa elongatu Torr.).-An erect perenuial 6 to $9 \mathrm{dm}$. high, with tlat leaf blades and narrow, rather deusely tlowered panicles. - In rich, wet woods, New foundlaud and New Brunswick to North Carolina, west to Quelec, Minnesota, and Kentucky. July-September. 


\section{1}

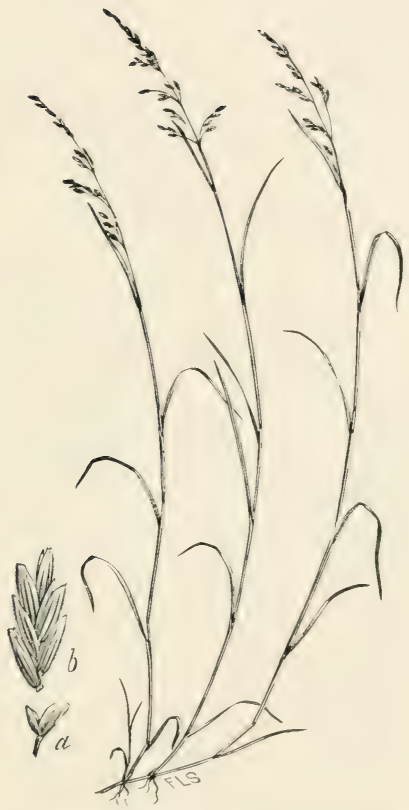

Fif: 283. Panicularia pallida (Torr.) Kuntze (filyceria pullield Trin. Windsoria pallida Torr.). Pale Maxya-grass.-A perennial, with slender stems 3 to $9 \mathrm{dm}$. long, ascending from a more or liss decumbent base, and a lax, fi-w-flowered panicle with ascencling branches.- bogs, bauks of streams and poncls, Cape Breton to ()ntario, sonth to Virginia, eastern Tennesseo and Indiana. June-August. 


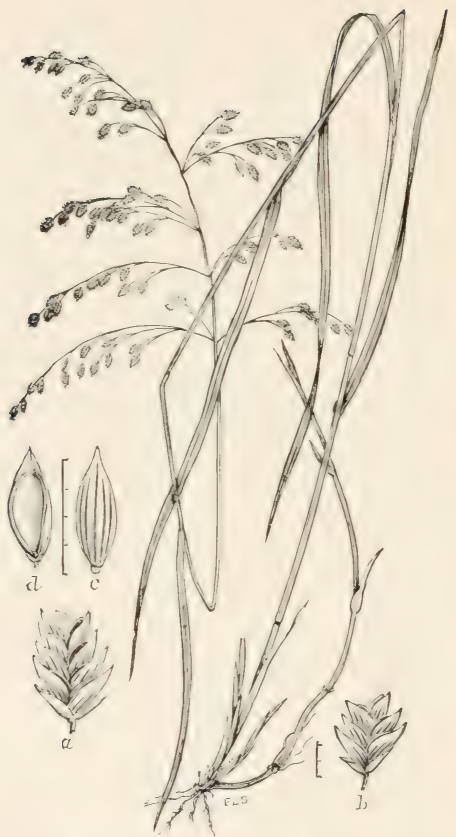

FIf. 284. Panicularia canadensis (Michx.) Kuntze; Britton and Brown, Ill. F1., 1: 211 (Glyceria canudensis Trin.). RATtLEsxake-diliss. - A stont, native peremial 6 to 9 dm. high, with flat leaves, and ample, nodding panicles of rather large spikelets.Marshes and ditches. Newfoundland and Nova ficotia to Minnesota, south to New Jersey, (Ohio, aud Kansas. June-August. 


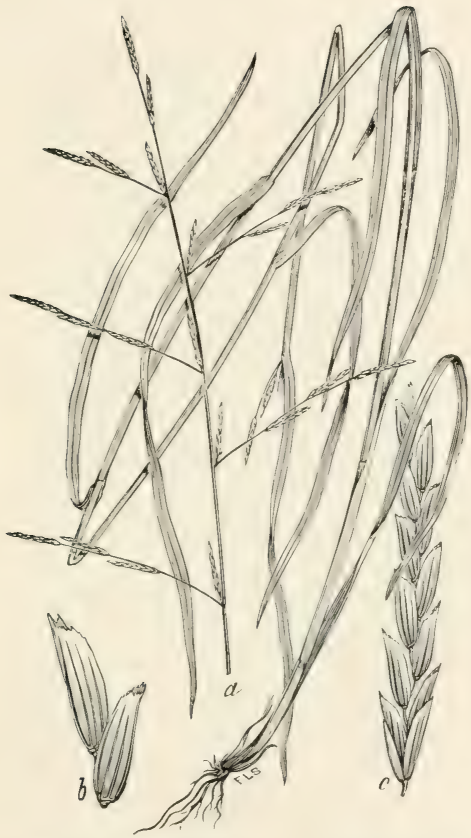

Fig. 285. Panicularia fluitans (L.) Kuntze ('ilyceriu fluitans R. Br.). Flonting Maxidiliasi.-Anerect grass9 to 15 dm. high with somewhat flattened enlms, long leaves, aud a narrow panicle abont $3 \mathrm{dm}$. long.- Wet places, often in running water, New foundland to Alaska, south to North Carolina, Tennessee. Texas, and California. [Widely distributed in tem]erate regions.] MaySeptember. 


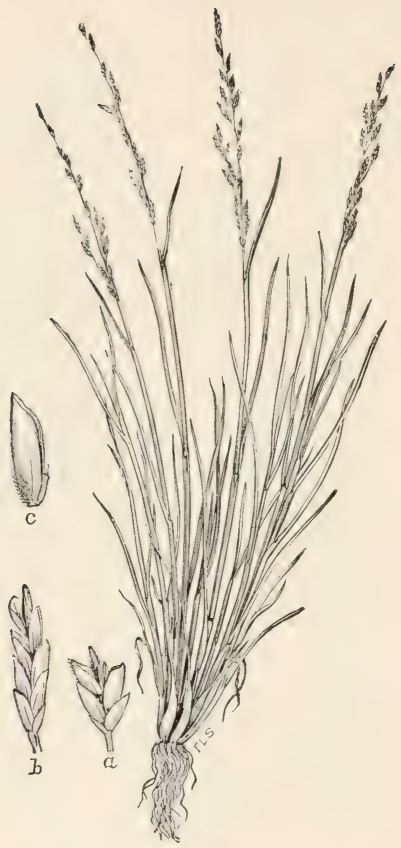

FIG. 286. Puccinellia maritima (Huls.) Parl. (I'ou maritima Huds.; Glyceria maritima M. \& K.). SEA SPEAR-GRASs.-A slender perennial 2 to $5 \mathrm{dm}$. high, from ereepiug rootsto $k s$, with narrow, flat, or folded leaves, and more or less expanded panicles 8 to 12 en. long. - Salt marshes and beaches along the coast, Labrador to southern New England, and Alaska to British Columbia: also on ballast and waste gromel in sea ports farther south. [Europe and Asia.] July, August. 


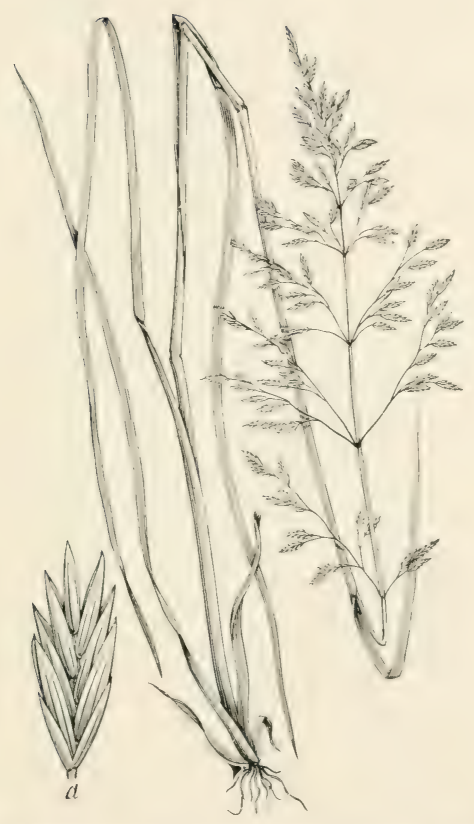

Frr. 2×T. Festuca elatior arundinacea (Nehreh.) Hack. REED FEscte. - A stont, leafy perennial a to 12 dm. high, with hroad, flat leaves, and ample. elongated panicles often : 1 lm. long.-Introduced here and there, listrict of Columbia, Miehigan, Utah, Oregon, etc. [Europe.] Angust.

$11162-$ No. $7-20$ 


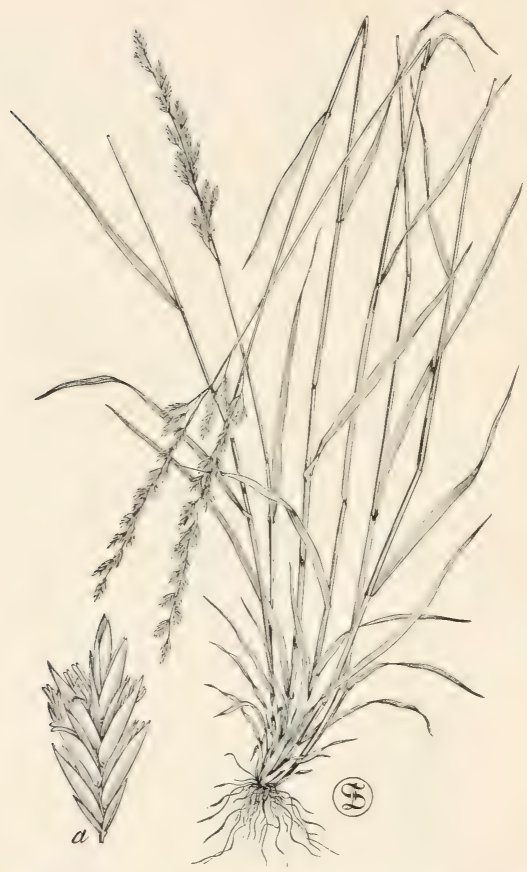

FIG. 288. Festuca elatior pratensis (Huds.) Hack. MEADow FESCUE.-An upright peremnial i to $9 \mathrm{dm}$. high, with numerous flat leaves and a rather narrow panicle 10 to $20 \mathrm{~cm}$. long. - In fields and waysides, introduced, Nova Mcotia to North Carolina, west to Washington, Oregon, and Kansas. June-August. 


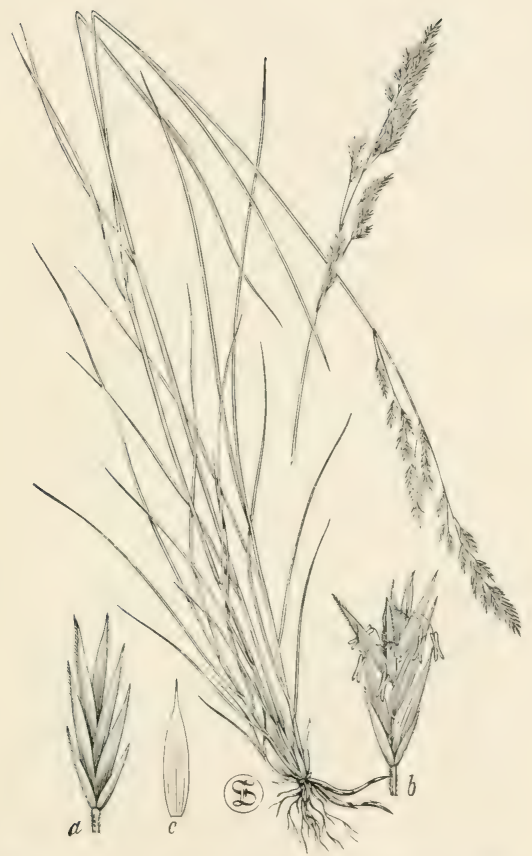

Frt. 289. Festuca rubra glaucescens Hack.; lieal, (irasses X. Am., 2 : 606. Texprsse Fencle. -1 slender perennial 3 to 6 dim. high, with ereeping rootstocks, erect or ascending stems, very narrow, usually glancons leaves, and lax, noddng pancles. Forms a dense turf.-Bhufis of C'umberlaud liver, Nashville, Tonn. May. 


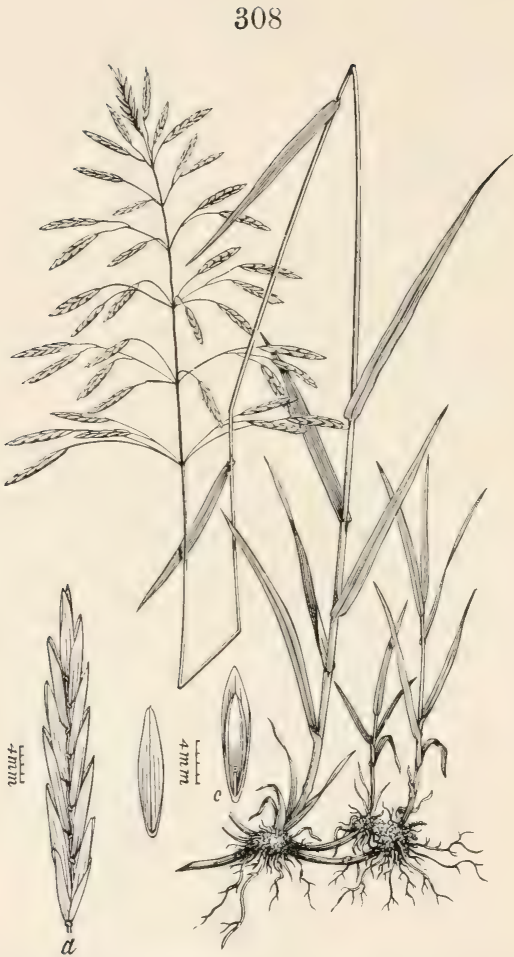

Fig. 290. Bromus inermis Leyss. SMoоth Biome or HuxgaRIAN BRoMe-Grass.-An erect perennial 6 to 15 din. high, with creeping rootstocks, open panicles 12 to $18 \mathrm{~cm}$. long, and five- to nine-Howered, awnless spikelets 2 to $3 \mathrm{~cm}$. long.-A native of Europe, introduced and cultivated in many parts of the United States for hay, June, July: 


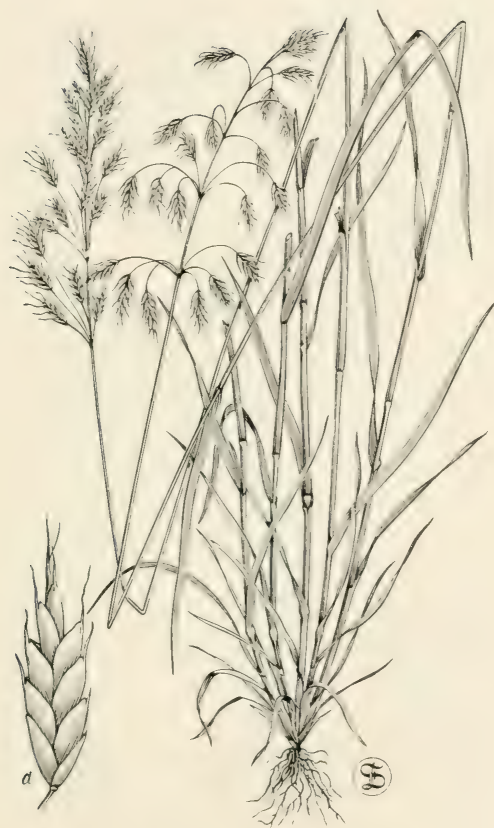

Fic. 291. Bromus secalinus I. C'HEss or ('HEAT.-An erect anmual 6 to 9 dm. high, with flat leaves, more or less expruted panicles, anci turgid, short-awned spikelets, which are pendulous in fruit.- Naturalized in eultivated and waste yround-, especially in grain fields. [Europe and Asia.] June-August. 


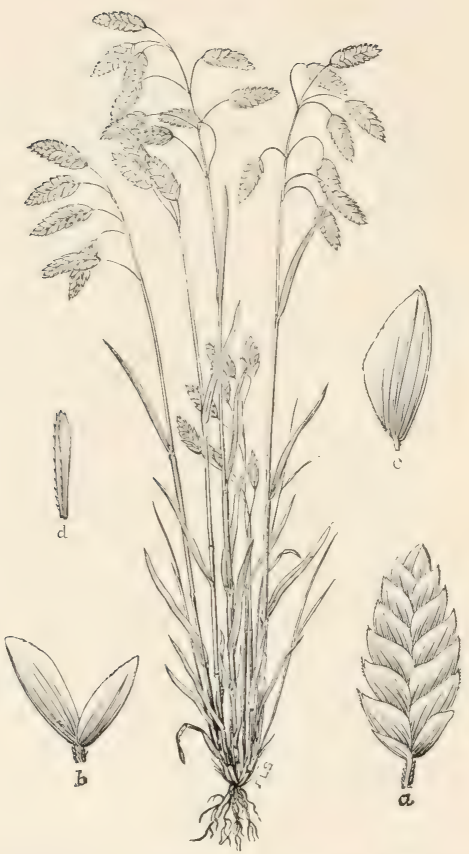

FIG. 29:. Bromus brizaeformis Fisch. \& Mey. BRI7A-LIKE Brome-tikass-- A slender, erect, cirspitose annual 2 to $5 \mathrm{dm}$. high, with soft, flat leaves and nodding panicles of large ten- to tifteenflowered spikelets 2 to $3 \mathrm{~cm}$, long.-Meadows and cultivated fields, introduced, Moutana to Washington, south to Utah, Nevada, and California; sparingly in Massachusetts, New York, and Pennsylvania. [Europe and Asia.] June-August. 


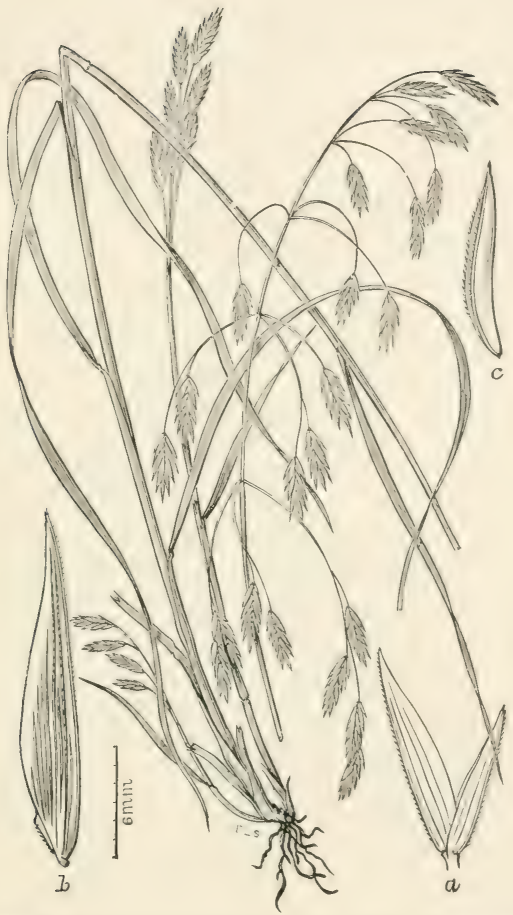

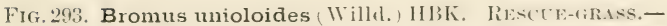
An crect, usmally annual grass, :3 to 9 dm. high, with more or less fubescent, flat leaf blades. and usually modiling, loose panicles of rather laree, strongly tlattemed spikelets.-Prairies and dry, samely fields, Indian Territory and Texas to Arizona; naturalized in Alabama. [Mexico aud fouth America.] March-July. 


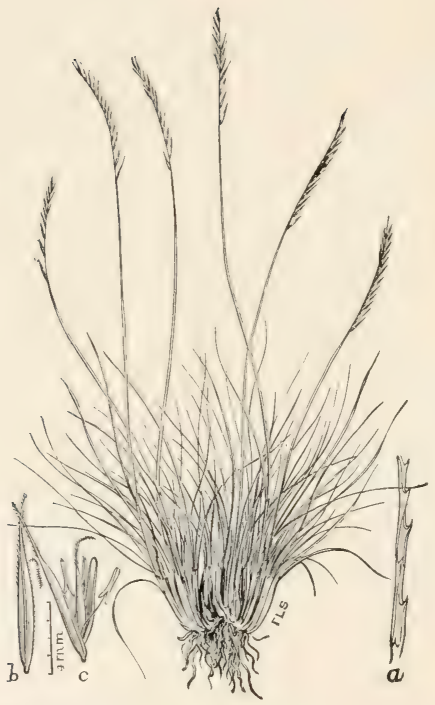

FIG. 294. Nardus stricta L.; Britton and Brown, Ill. Fl., 1: 224. W1IE BENT. - A glabrous, densels cispitose perennial, with stout, creeping rootstocks, setaceous leaves, and erect, filiform, rigid culms, 10 to $20 \mathrm{~cm}$. high.-Introduced at Amherst, Mass.; rocky river banks, Newfoundlaud. [Europe, Greenland an? Azores.] August. 


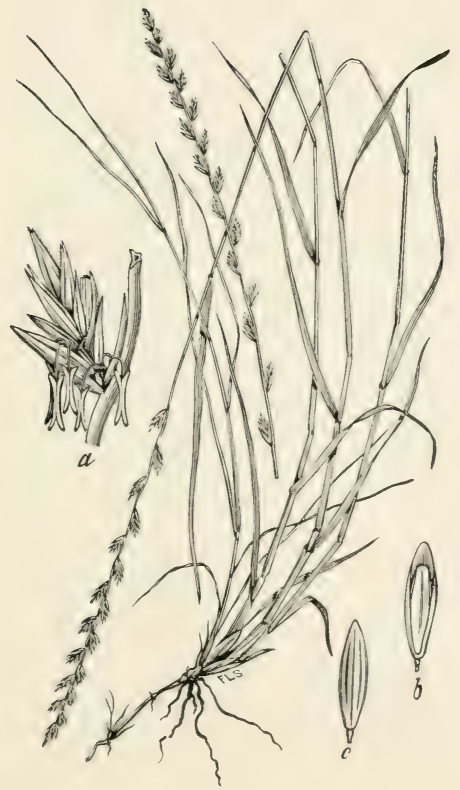

Fig. 295. Lolium pereme L. RYE-tiluss.-1 smooth, leafy perennial 3 to $9 \mathrm{dm}$, high, with slender, terminal spikes 7.5 to 2 ; 'm. long.-Lawns, fields, and waysicles, naturalized, Canada to North Carolina, west to (Hio and Tenmessere: ('alifornia and Arizona. [Europe and Asia.] Mas-August. 


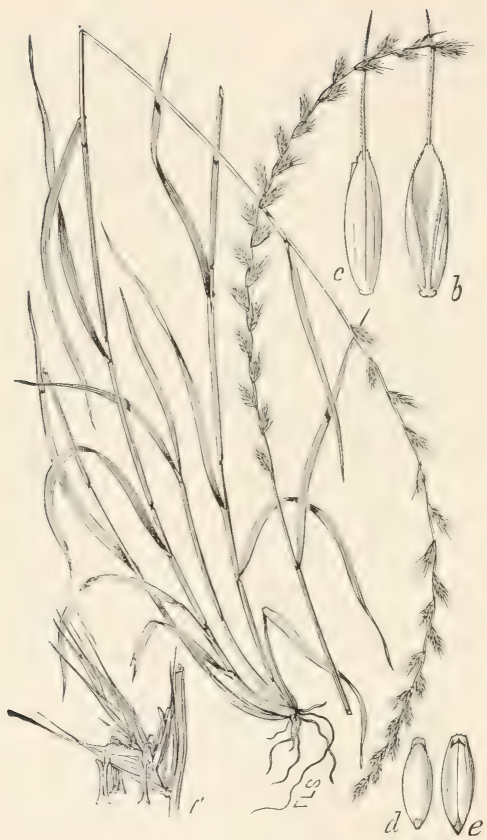

Fig. 296. Lolium italicum A. Br. Itamiax Rye-grass,-A hiennial or pereunial grass 6 to $9 \mathrm{dm}$, high, with slencler, 1 sually somewliat nodding, terminal spikes, and short-awned spikelets. A valuahle hay grass.-Introduced here and there through cultiration, especially on the Pacific Slope. 


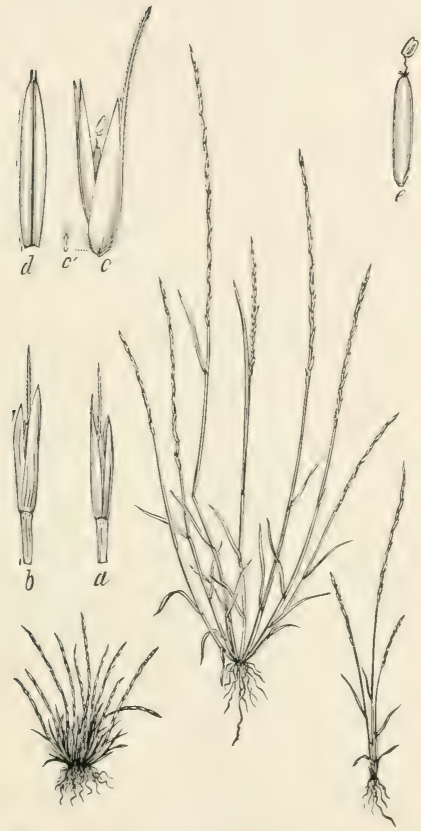

Fir. 297. Scribneria bolanderi (Thurb.) Ilack. (Iepturus bolunderi Thurb.). Beal, Grasses X. Am., 2 : 63!.-A slender, wiry, carspitose anmual 1 to $2 \mathrm{dm}$. high, with short, narrow leaves and terminal, slightly compressed spikes.-Sterile grounds, hillsisles, and roadsides, Washington to California. May. 


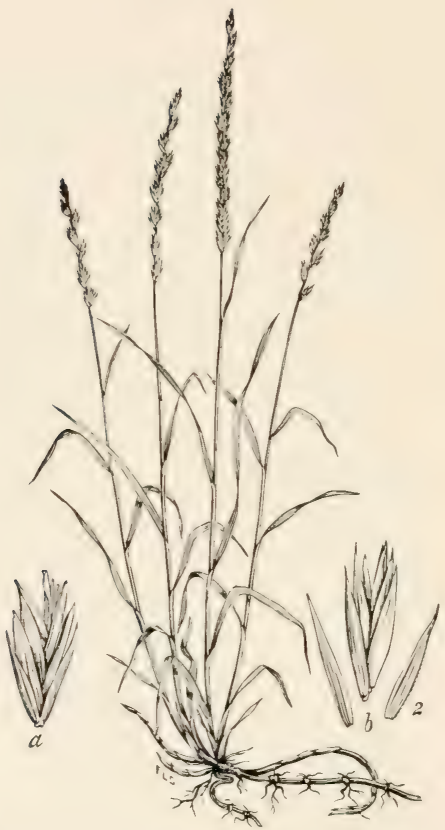

Fig. 298. Agropyron repens (L.) Beauv. (Triticum repens L.). Cot'H-GRAss. - An erect, stoloniferous perennial 3 to $12 \mathrm{dm}$. high. with flat leaves, which are pilose along the nerves above, and terminal, densely flowered spilies.- Xaturalized in lawns, waysides, and cultivated ground. Newfoundland and Cape Breton to Northwest Territory, soutl to District of C'olumbia, Ohio, and Iowa. [Europe and Asia.] June-September. 


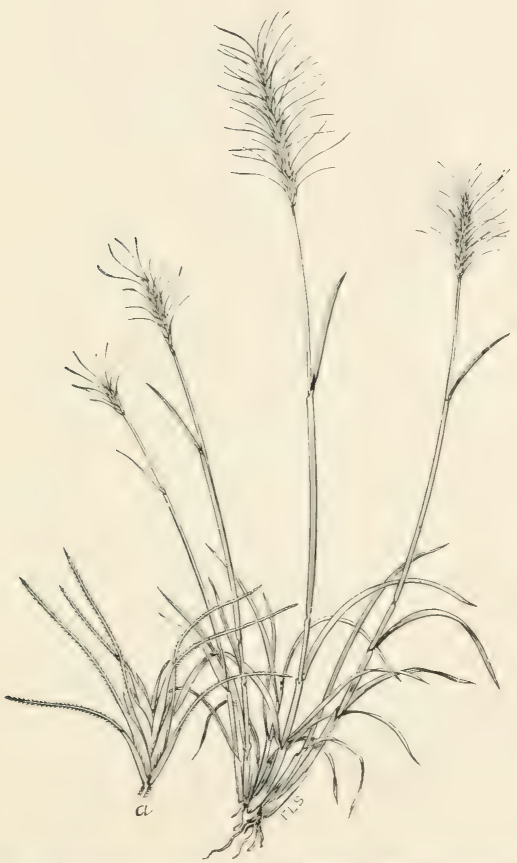

FIr. 299. Agropyron scribneri Vasey; Beal, (irasses X. Am., 2:638. - A densely ciespitose perennial 2 to is dm. high, with ascending culms, tlat leaves, and bearded spikes 5 to $7 \mathrm{~cm}$. loug. which readily break 11 at maturity.-Summits of mountains (alt. 1,800 to $4,200 \mathrm{~m}$.), Montana to ('olorado and Arizona. August. 


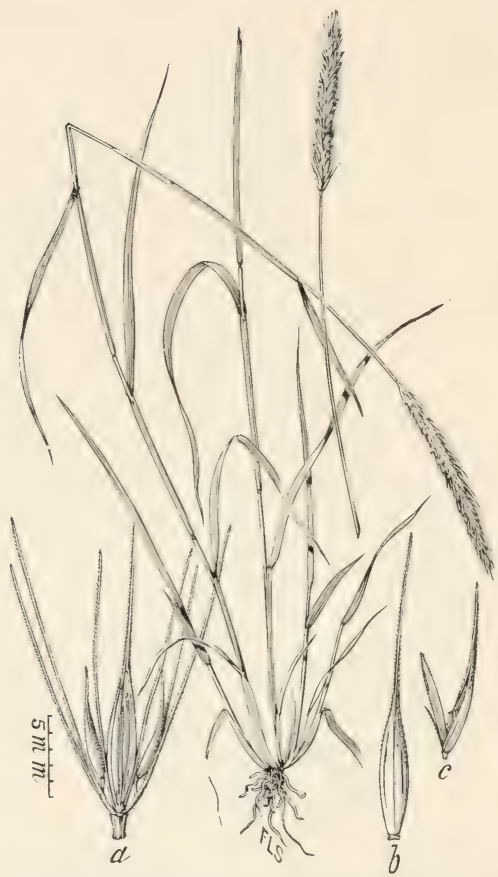

FIG. 300. Hordeum boreale ścribn. \& Smith, Bull. 4, Div. Agrost., 28 (1897). Northers Wild Barley.-A slemder, erect and apparently perennial grass 3 to $6 \mathrm{dm}$. high, with rather broad, flat leaves, smooth culms and terminal spikes 7 to $10 \mathrm{~cm}$. Jong.-Mountains of California to Alaska and Bering Sea islands. June, July. 


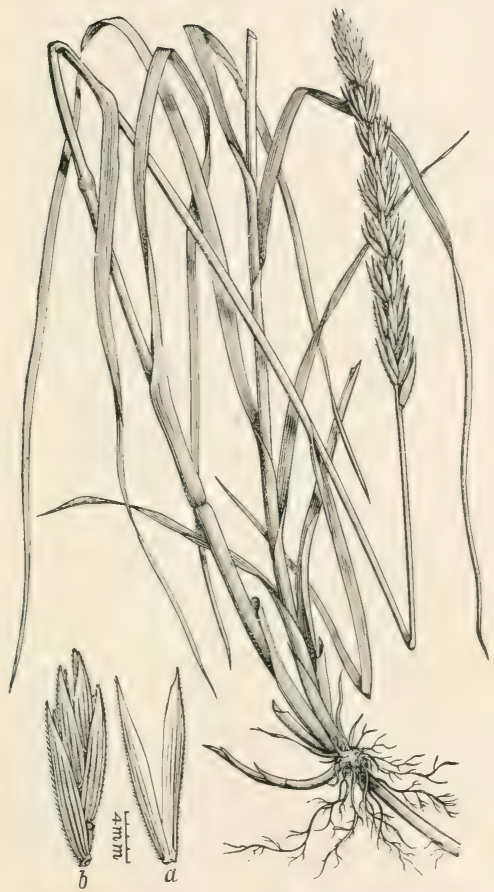

Fig. 301. Elymus arenarius L. SEA LYMe-GRAss.-A stont, erect perennial if to $12 \mathrm{~cm}$. high. with extensively creeping rootstocks, rather tirm, flat, sharp-pointed leaves and terminal, usually deusely tlowered spikes $\times$ to $25 \mathrm{~cm}$. long. (ilumes usually villous. In maritime sands, (ireenland and Labrador to Maine; Alaska to California and on the shores of the Great Lakes. [Europe and Asia.] July, August. 


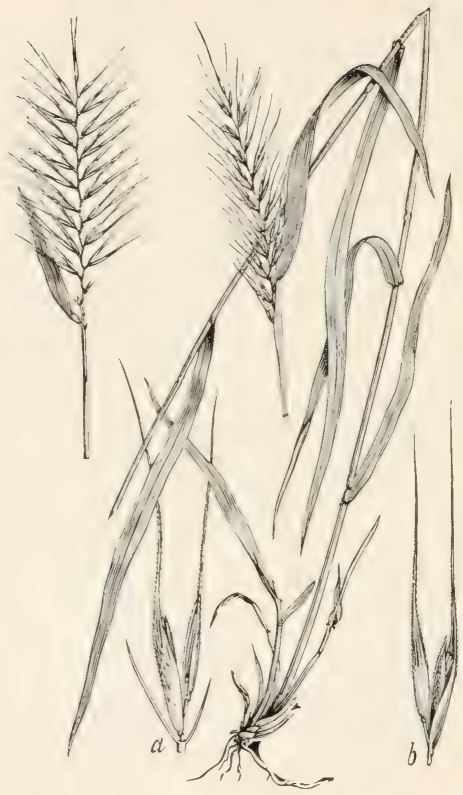

FI(i. 302. Asperella hystrix (L.) Moench (Asprella W. not Schreb.; Hystrix patula Moench; (iymnostichum hystrix Schreb.). Bottle Brish. - A smooth, eiespitose perenuial 6 to $12 \mathrm{dm}$. high, with rather broad, tlat leaves and terminal spikes 6 to $12 \mathrm{~cm}$. long. Spikelets widely spreading at maturity-Fertile, rocky wools, New Brunswick and Ontario to Georgia, Alabama, Arkansas, and Minnesota. June-August. 


\section{INIDEX TO THE (O)IION NAUES.}

Page.

Alkali.grass . . .................. 285

Saceatone............... 74

American Oat.................. 183

Banner Sorghim. ................ 34

Barley ....................... 14

Barnyard-grass . . .............. 82

Beacb-grass................... 167

Bearded-joint................. 77

short-husk ............. 130

Beard-grass.................. 150

Bermuda-grass.................. 189

Big Blue-stem................. 32

Bitter Panic-grass ............. 73

Black Bunch.grass.............. 38

Grama .................. 37

Momntain Rice ............ 110

Blue Grama.................. 22. 22

Bottle Brush. . ................ 320

Branching Foxtail ............ 8.7

Bristly Mesquite................ . 223

Briza-like Brome-grass ........ . . 310

Broad-leafed Spike-grass.... . . . . . 282

Brook-grass.................... 27

Broom Sedge.................... 28

Buffalo-grass................ 12, 238

Bunch Redtop ................. 296

Burk's Gramat ... ............... 2.25

California Hair-grass . . . . . . . . 172

California Timothy ............. 99

('anary-urass . . . . . . . . . . . . . 10

Carpet-grass................. 42

Catch-fly-grass............... 92

Cheat .......................... 309

('liess ....................... 309

Clustered Salt-gras. ............ 230

Common Reed ................. 247

Cotta-grass .................... 241

$11162-N_{0}, 7-21$
Page.

Cotton-grass ................. 60

Conch-gras. ................... 316

Crab-grass ................... 9, 258

Creek Setge ................... 195

Creeping Mesฉquite ............. 36

Panic ................ 70

Reimaria............ 40

Crow foot-grass.................... 228

Densely-flowered Bent .......... . . 155

Plume-grass .... 21

Dog's-tail-grass ................. 273

Downy Oat-grass............... 178

Early Bunch-grass.............. 270

Wild Oat-grass............ 171

Eaton's.grass .................... 269

Elliott's Broom Sedge........... 30

Paspatum.............. 41

English Ray.grass .............. 14

Everlasting-gıss.............. 53

False Buffalo-grass .............. 245

Feather-grass ................... 237

Few-Howered Sorghum ......... 35

Fine-top Salt-grass ............. 145

Flat-stemmed Panic ............ 71

sporobolus......... 143

Floating Foxtail ............... 133

Manna-grass .......... 303

Florida Amphicarpon........... 51

P'aspalum ............... 48

Fowl Meadow-grass ............. 239

Fox-grass ................... 192

Freshwater Cord grass. . . . . . . . . 191

Galleta..................... 8, 39

Gama-grass ..................... 19

Gibbous Panic-grass........... 65

Goliten Top ................... 288

Goose-grass .................... 227 
Green Foxtail.................. . 83

Nealley's Leptochloa............. 234

Hairy Grama.................. 220

Havard's Grama................ 216

Herd's grass .................... 11

Hungarian Brome-grass ...... . . . 308

Hungarian-grass ................. 86

Incian Corn .................. 7

Iudian-grass ................... 33

Millet ................. 115

Reed .................... 152

Italian MIillet .................. 86

Ray-grass .............. 14

Rye-grass ............... 314

Jamaica Crab-grass............. $6 i$

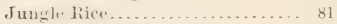

Kellogg's Spear-grass............ 292

Kentueky Blue-grass ......... 13, 291

Knot-urass................. its

Large-flowered Melica ........... 278

Large-leafed Vanilla-grass....... 102

Large Water-grass............... 49

Lemmon's Tool-grass ........... 54

Little Blue-str.n. .............. 31

Crab-grass............... 56

Lizard-tail grass ................ 24

Long-awned Poverty-grass ...... 106

Long-leafed Sporobolus .......... 139

Long-spiked Bur-grass........... 88

Long-stalked Panic .............. 80

Lonisiana-grass............... 42

Maize ....................... 7

Many-flowered Trichloris......... 208

Many-spiked Chloris............. 205

Marram grass................... 167

Marshy Oat-grass .............. 177

Mat-grass .................... 23

Meadow Fesene................. 306

Foxtail ................ 134

Mexiran Inropseed ............. 118

Millet..................... 9

Mission-grass ................. 90

Mforton's Oat-grass............... 184

Mountain Foxtail .............. 135

Hair-grass ............ 176

Spear-grass . . . ........ 290

Naked Beard-grass.............. 209

Nimble Will ................... 117

Nit-grass ..................... 159

Nodding Oat.grass ............. 182

Pleuropogon............ 281

Northern Panic-grass ............ 76

Wild Barley ........................ 318

Oat-like Hair-grass ............. 175

Uat....................... 12

One-flowered Grama ............. 212

Orchard-grass .............. 13, 287

Pale Manna-grass ................ 301

1'hippsia...................... 136

Porenpine-grass . ............... 107

I'rairie-grits................... 137

Spear-grass ............. 295

Purple Canarr-grass............. 97

l'urple pras . . . . . . . . . . . . $\$ 39$

P'ursh's Amphicarpon ........... 50

Quaking-grass................. 286

liattlesnake-grass ............ 302

Fiedfield's grass................. 256

Reed Fistle ................. 305

Mealow.grass ............. 298

Rescue-grass.................... 311

Rice ....................... 9

Rice Cut-grass ................... 94

Rocky Mountain Oat-grass ...... 179

liothrock's Grama ............ . . . 221

límgh Foxtail ................. 84

Leptochloa ............. 233

liound-tlowered Panic ........... 75

Rush-like Spartina............... 194

Timothy ............ 131

Rye......................... 14

Rye-grass . . . . . . . . . . . . . . . 313

Salt Certar ...................... 244

Reed-urass ................ 190

Saud $131, \ldots \ldots \ldots \ldots \ldots \ldots . . . \ldots$ si

Sea Lyme-grass.................. . 319

Sea Spear-grass ................. 304

Seaside Finger-grass........... 200

Oats................... 283

Short-awned Grama....... . . . . . . . 219

lised-grass .......... 161

Short-haired Reed-grass ......... 168 


\begin{tabular}{|c|c|}
\hline $\begin{array}{r}\text { hort-leafed Beard-grass.......... } 210 \\
\text { hort-stalked Eragrostis........ } 260 \\
\text { Yeadow.grass..... } 265\end{array}$ & 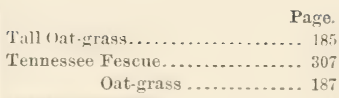 \\
\hline de Oats.......................... 213 & T.xan ( rab.grats............. 211 \\
\hline ky Oat-grass ................... 188 & Grama.......... \\
\hline lver Beard . . . . . . . . . . . . . . . . 29 & Texas Blue-grass ..... \\
\hline Panic-grass............. 58 & Millet ........... \\
\hline d-grass............... 29 & Thateh .................. \\
\hline & .. 279 \\
\hline ............... 181 & la........ \\
\hline te......... & , \\
\hline$\ldots \ldots \ldots \ldots \ldots .96$ & ass............ \\
\hline ropseed ........ 119 & eard-grass ...... \\
\hline s.............. 1 & (n......... \\
\hline$\ldots \ldots \ldots \ldots \ldots 180$ & \\
\hline$\ldots \ldots \ldots \ldots \ldots \ldots$ & ............. \\
\hline 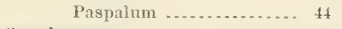 & \\
\hline$\ldots \ldots \ldots \ldots \ldots \ldots \ldots+26$ & (......... \\
\hline I Momntain Rice.... 114 & $8 \ldots . .$. \\
\hline$\ldots \ldots \ldots \ldots \ldots 224$ & s........... \\
\hline anic-grass......... 64 & s....... \\
\hline . . . . . . . 308 & ... \\
\hline 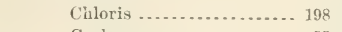 & (n................. \\
\hline$\ldots 5$ & Kice ............ \\
\hline lum............ & $\ldots \ldots .$. \\
\hline$\ldots \ldots \ldots \ldots \ldots \ldots \ldots \ldots$ & 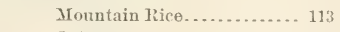 \\
\hline$\ldots \ldots \ldots \ldots \ldots \ldots, 52$ & ........... \\
\hline -grass .......... 98 & \\
\hline (S . . . . . 259,294 & ..... \\
\hline ( $\ldots . . . . .$. & \\
\hline$\ldots \ldots \ldots \ldots 158$ & ( \\
\hline …..... 69 & (.......... \\
\hline Sporobolus........ 139 & Woodland Dropseed.... \\
\hline 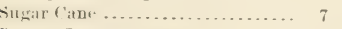 & grass... \\
\hline s........... 1 & S17 \\
\hline grass .......... 10, & grass.......... \\
\hline$\ldots \ldots \ldots \ldots \ldots \ldots \ldots$ & \\
\hline all $G$ & \\
\hline
\end{tabular}





\section{INDEX TO THE LATIN NAVIES.}

[Tribes in SMALL CAPITALs and synonyms in italics.]

Page.

Egilops aromatica .............. 196

Agopogon .................... 8

Agropsron...................... 14

repens.............. 316

scribneri ............ 317

AGROSTIDE E ................. 10, 12

A grostis .................. 10, 11

arachnoides............ 158

asper................. 137

coaretata.............. 154

compressa.............. 143

densiflora. . . . . . . . . . 155

diegö̈nsis .......... 157

elliottiana............ 1;

foliosa............... $15 i$

humilis............... 153

varians ............... 153

Aira .................... $[12$

caryophyllea.............. 170

danthonioides .............. 175

nitida.................. 271

priecox.................. 171

subspicata . .............. 178

Alopecurus ................... 10, 11

geniculatus .......... 133

occidentalis ......... 135

pratensis............ 134

Ammophila ................... 11

arenaria............ 167

arundinacea ........ 167

Amphicarpon ................. 9

tiorjdanum......... 51

purshii ............ 50

Andropogen ................. 7

argyrieus........... 29

elliottii............ 30
Page.

Andropogon furcatus ............ 32

glomeratus.......... 27

macrourus........... 27

nutans ............. 33

paucitlorus .......... 35

polydactylon......... 205

provine:alis . ....... 7,32

saccharoides......... 26

scoparius............ 31

secundus ............ 34

twirymus. ......... 26

unilateralis.......... 34

virginiens.......... 7,28

ANDROPOGONEA ............. $i$

Anthienantia ................ 9

Anthoxantium ................. 10

odoratum........ 100

A pera.................... 11

Aretagrostis................. 11

Aristida ..................... 11

gossypina ............. 105

lanata ............... 105

palustris .............. 104

stricta .............. 103

tuberculosa........... 106

Arrhenatherum................. 12

elatius ......... 185

Arundinaria .................. 15

Arumilo ...................... 13

brevipilis.............. 168

phragmites ............. 247

vulgaris ............... 247

Asperella ...................... 14

hystrix............... 320

Asprella hystrix................. 320

A vena ...................... 12 


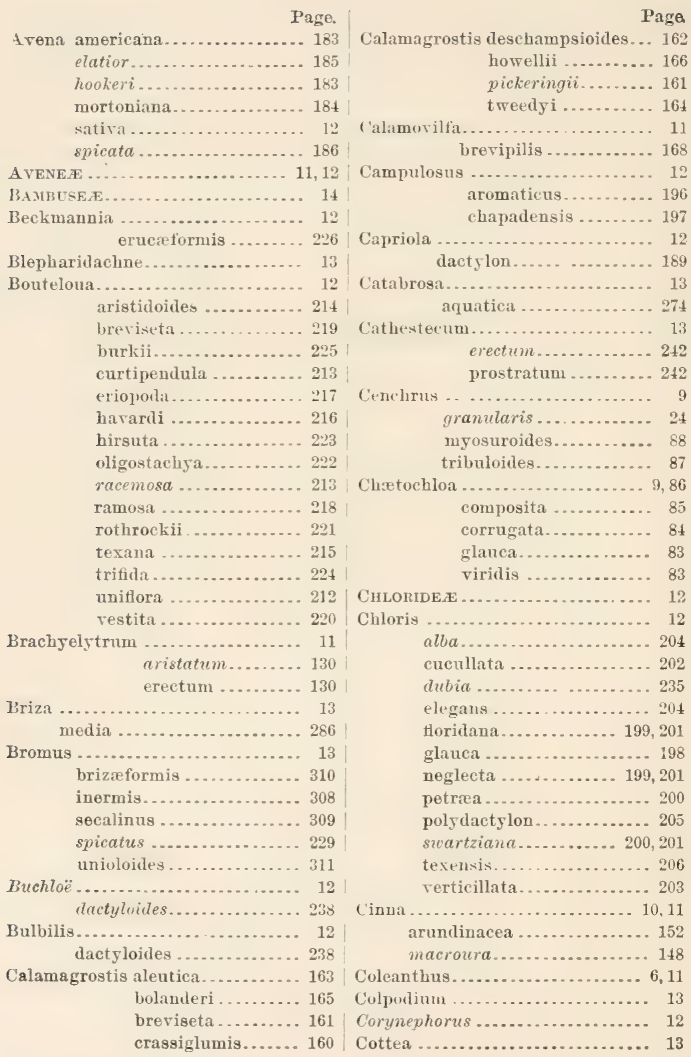




\section{7}

Page.

Cotted pappophoroides........... 241

Crypsis schonoides ............... 131

Ctenium ........................ 12

americanum ............ 196

chapadense ............ 197

Cynodon...................... 12

dactylon ................ 189

Cynosurus ..................... 13

trunptius ............ 228

cristatus .............273

Dactylis ....................... 13

glomerata............ 13, 286

maritima ............... 195

patens ................. 192

Dactyloctenium................. 12

regyptiacum ...... 228

agrptium ........ 228

Danthonia ..................... 12

compressa ............ 187

sericea.............. 188

spicata............... 186

Deschampsia.................. 12

atropurpurea....... 176

ealycina............ 175

elongata............ 174

flexuosa ............ 173

holeiformis......... 172

Diarrhena...................... 13

americana............ 280

Digitaria serotina .............. 56

Diplachne dubia.................. 235

imbricata ............ 232

reverchoni............. 229

rigida ................ 268

spicata . . ........... 229

viscidlt ................ $\$ 31$

Dissanthelium .................. 13

californicum....... 257

Distichlis ................. 13

maritima............. 285

spicata ............... 285

Dupontia ..................... 13

Eatonia .................... 13

dudleyi ................. 271

filiformis ............. 272

nitida.

271
Page.

Eatonia obtusata............... 270

pennsylranica............ 269

Eleusine ................... 6, 6,12

indica ................. 227

Elionurus....................... 7

barbicnlmis ........... 25

Elymus...................... 14

arenarius............... 319

Epicumpes .................. 11

ligulata............. 149

rigens ............... 148

Eragrostis ..................... 13

abyssinica ............ 258

brownii ............. 262

eiliaris .............. 266

conferta .............. 264

curtipedicellata ....... 260

frankii .............. 265

glomerata ............ 264

hypnoides............. 263

neo-mexicana......... 258

pectiuacea........ 260, 261

plumosa ............. 267

purshii .............. 259

reptans .............. 263

sessilispica ........... 268

Eremochlö̈...................... 13

Erianthus...................... 7

compactus............. 21

strictus............... 22

Eriochloa .................... 9

lemmoni.............. 54

mollis ................ 52

punetata............. 53

Eriocoma euspiclata............ 115

Euchlitna................... $i$

Eustachys floridana.............. 201

glauea ................ 198

Festura ................... 13

elatior arundinacea ...... 305

elatior pratensis......... 306

rubra glaucescens....... 307

FE⿱T⿰㇀丶㇀

Gastridium .................... 11

australe............. 159

lendigerum ........... 159 


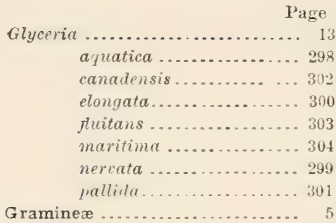

Graphephorum................ 13

trxursum ........ 256

melicoideum ...... 297

Greenia arkansana.............. 151

Grmnopogon................ 12

ambiguus .......... $\mathbf{2} 09$

brevifolins .........2 210

racemosus .......... 209

Gymnostichum hystrix ........... 320

(i) nerium................... 13

Hatkelorhlor ...............

granularis .......... 24

Heleochloa................... 11

schienoitles ........... 131

Hemarthria fasciculata .......... 23

Hierochlö̈ .................... 10

boreatis.............. 101

macrophylla .......... 102

Hilaria...................... 8

cenchroiles ............ 36

jamesii... ............... 38

mutica............... 37

rigita ................. 39

Holcus . . . . . . . . . . . . . . . . . . 10,12

lanatus .................. 169

Homalocenchrus.............. 9

hexandrus...... 9:

lentieularis..... 92

monandrus ...... 96

oryzoides........ 94

virginicus ...... 95

HORDEF..................... 14

Hordeum ................... 14

horeale................ 318

Hydrochloa .................. 9

Hystrix patula................. 320

Imperata ................. $\overline{7}$
Page.

Imperata brevifolia ............. 20

caudata ................ 20

hookeri .............. 20

Ischcemum secundatum ......... 90

Kuteria.................... 13

Koryearpus.................. 13

diandrus ........... 280

Lagurus .................... 11

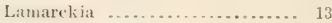

aurea ............. $2 \times 8$

rerisia........................

hexandra............... 93

luticularis............

monandra............... 96

aryzuiles............... 94

virginica ................ 95

Leptochloa................... 12

dubi................. 235

fascicularis ......... 230

imbricata............ 232

langloisii ............ 233

mucronata ........... 237

nealleyi............. 234

pringlei............. 236

scabra.............. 233

spienta .............. 229

stricte ............... $2: 3 t$

viscidlit ............... 131

Lepturus ..................... 14

bislanderi................ 315

Lesourdia karwinskyana........ 243

multiflora............ 243

Limnodiat ..................... 11

arkansana ............ 151

Iolium........................ 14

italicum................. 314

perenne..................... 313

Lophochlaena refracta ........... 281

Luziolit ....................... 9

alabamensis............. 91

Lусития ..................... 11

M:ınisuris.................... 7

compressa............. 23

granularis............. 24

MAYDE....................... 6

Mtelica ....................... 13 
Page.

Melica bulbosa................. 279

glabra .................. 275

untira................. 27

pariritlora .............. 276

porteri................. 276

spectabilis.............. $27 \pi$

stricta................. 278

Ifilinm .................... 11

efĭustum $\ldots \ldots \ldots \ldots \ldots \ldots .116$

lendigerum.............. 159

Miseantlus...................

Molinia ....................... 13

Monanthochloë ................ 13

littoralis......... 24t

Muhlenbergia................ 11

diflusa ........... 117

filiculmis ......... 126

glomerata ......... 121

gracilis .......... 129

gracillima......... 124

mexicana ......... 118

porteri............ 123

pringlei ........... 122

pungens ........... 125

racemosa.......... 121

schaffneri......... 127

sylvatica ......... 120

tenuifiora .......... 119

texana ............ 123

virescens ......... 128

villdenovii ......... 119

Munroa ..................... 13

syuarrosit ............. 245

Nardus ........................ 14

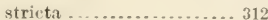

Nazia ................... 8

Oplismenus................... 9

Orcuttia ..................... 13

ealifornica............. 246

(1)yzal sativat ................... 9

(1:X\%E.1..................... 9

Oryzopsis................... 11

asperifolia........... 111

exigua ............... 113

timbriata............ 112

kingii................ 108
Page.

Oryzopsis melanocarpa.......... 110

membranacea .......... 115

micrantha............. 114

mongolica............. 109

I'ANICAI'E.F. . . . . . . . . .

PANICE..................... 8

Panieularia .................... 13

aquatica ............. 298

canardensis .......... 302

elongata . . .......... 300

Huitans ............. 303

nervata .............. 299

palliıla ............... 301

Panicum ..................... 9

amarum .............. 73

anceps................. 71

barbulatum ........... 77

horeale ................ 76

bulbosum............. 74

colonum ............... 81

columbianum ............ 78

corrugatum ............ 84

crus-galli ............... 82

dactylon............... 189

demissum .............. 79

filipes ............... 68

viblum.............. 65

glalirum .............. 55

gracillimum ........... 57

grossarium............. 61

hians ............... 66

lanatum............. 60

leucophaum........... 60

lineare ................ 55

longiveduneulatum..... 80

melicarium ............. 66

molle.................. 52

naslianum ............ 79

ohtusum.............. 6i3

paspaloirles............ 59

pheothrix.............. 58

prolifirum .......... 69

repens............... 70

sanguinale ............. 189

serotinum ............ 56

spherocarpun ....... 75 
Page.

Panicum stenodes............... 64

texanum .............. 62

verrucosuiu ............ 67

virgatum............. 72

viride.................. 83

Pappophorum.................. 13

apertum ........... 240

boreale............. 239

wrightii ........... 239

Paspalım ..................... 9, 12

compressum ........... 42

ditforme .............. 47

duriturir............. 41

dilatatum.............. 49

distichum .............. 43

elliottii ................ 41

Horidanum ............ 48

lit.ve .............. 45

oratum ............... 49

paspaloides............ 41

platycaule............. 42

plicatulum ............ 46

setaceum .............. 4

Pennisetum ................... 9

setosum ........... 89

Pereilema..................... 11

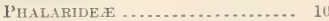

Phalaris ..................... 10

amethystina ........... 97

angusta................ 99

caroliniana ............. 98

erucceformis ............. 226

intermedia............... 98

Pharus ..................... 9

Phippsia...................... 11

algida ................ 136

Phleum....................... 11

pratense ............... 132

schoenoides ............. 131

Phramites ................. 13

communis........... 247

rulgaris .............. 247

Pleuropogon.................. 13

refractum .......... 281

Pleuraphis rigida............... 39

Poa......................... 13
Pagre.

Poa alpina ..................... 290

ambigua .................. 250

arida...................... 295

brevifolia ................. 294

buckleyana ................ 296

chapmaniana................. 289

ciliaris.................... 266

conferta ................... 264

elongata..................... 300

glomerata ................... 264

liypmoides ................... 263

kelloggii ................... 29:

maritima .................. 304

pratensis................... 291

sylvestris ................... 293

tenuifolia ................. 296

POACE, F . . . . . . . . . . . . . . . . . 9

rolypogn ................... 11

monspeliensis........ 150

Puceinellia .................... 13

maritima ........... 304

Redfieldia.................... 13

Hlexuosa............. 256

Reimaria...................... 9

oligostachya ............ 40

livttmellin.................... ; compressa .............. 23

sacrharum................... 7

Savastana..................... 10

macrophylla .......... 102

odorata .............. 101

Schedonnardus................. 12

paniculatus ....... 211

texanus ........... 211

Scleropogon.................... 13

brevifolins .......... 243

serbluchloat ................. 13

Scribneria ...................... 14

bolandleri ............. 315

seralt ...................... 14

siturite...................... 9

composita ............... 85

corrugata ................ 81

italica ................... 86

viridis .................. 83

Sierlingia.................. 13 


\section{1}

Page.

Sieglingia acuminata ............ 253

albescenis ............... 251

americana............ 255

eragrostoides........... 248

nealleyi.............. 252

pulchella.............. 254

Sorghum pauciflorum.......... 35

Spartina .................. 10,12

cynosuroides ........... 191

densiflora.............. 194

glabra .................. 195

gouini ................. 194

gracilis ................ 193

juncea ................. 192

junciformis............. 194

patens................ 192

polystachya ............ 190

stricta maritima........ 195

Sporobolus................. 6, 11

airoiles ............. 145

argutus ............. 146

asper.............. 137

compressis .......... 143

confusus ............ 147

curtisii............. 142

Horidanus ............ 141

heterolepis .......... 139

indicus............... 144

interruptus .......... 140

longifolins .......... 138

Stenochloa californica.......... 257

Stonotaphrum ................. 9

americanum...... 90

secundatum ....... 90

Stipa........................ 11

kingii.................... 108

memüranacea .............. 115

mongolica................ 109

spartea .................. 107

Syntherisma linearis............ 55

serutina ............ 56

Thurleria.................... 11

arkansana............. 151

Trachynotia polystachya ........ 190

Trachypogon ................. 7

Tragus..................... 8

Tricbloris..................... 12

blanchardiana......... 207

fasciculata ........... 207

pluritlora ............ 208

Tricuspis monstrosa............ 243

Triodia ...................... 13

aeuminatit ............. 253

allescens ............... 251

anbigua ................ 250

eragrostoides ............248

neallesi............... 252

pulchella................ 254

texana .................. 249

Triplasis americana ............ 255

Tripsat.um.................. ;

dactrloides........... 19

Trisetum...................... 12

eanescens............. 18]

cernum .............. 182

. longatum ............ 181

interruptum .......... 180

montanum ............. 179

palustre .............. 177

subspicatum ........... 178

THISTEGINE. . ................

Triticnm....................... 14

repens................ 316

Uniola ....................... 13

gracilis .................. 28. 284

latifolia................. 282

laxa ...................... 284

paniculata............... 283

Vilfa arguta ................... 146

rigens ................... 148

Weingertueria .... . . ......... 12

Windsoria pallida................ 301

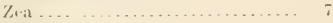

ॠizania $\ldots \ldots \ldots \ldots \ldots \ldots \ldots \ldots$

Zizaniopsis .................... 9

Zoysia .................... 8

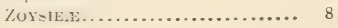


014280006 


$$
00^{2} \cos ?
$$

$\mathrm{QK}$

495

G74S3

$\mathrm{v} \cdot 1$

(1)

ESC
Scribner, Frank Lamson American grasses

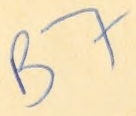

\section{6}


